Mariana Vercesi de Albuquerque

\title{
O enfoque regional na política de saúde brasileira (2001-2011): diretrizes nacionais e o processo de regionalização nos estados brasileiros
}

\author{
Tese apresentada à Faculdade de Medicina da \\ Universidade de São Paulo para obtenção do \\ título de Doutor em Ciências \\ Programa de Medicina Preventiva \\ Orientadora: Profa. Dra. Ana Luiza D’Ávila Viana
}

SÃO PAULO

2013 
Dados Internacionais de Catalogação na Publicação (CIP)

Preparada pela Biblioteca da

Faculdade de Medicina da Universidade de São Paulo

(C)reprodução autorizada pelo autor

Albuquerque, Mariana Vercesi de

O enfoque regional na política de saúde brasileira (2001-2011) : diretrizes nacionais e o processo de regionalização nos estados brasileiros / Mariana Vercesi de Albuquerque. -- São Paulo, 2013.

Tese(doutorado)--Faculdade de Medicina da Universidade de São Paulo.

Programa de Medicina Preventiva.

Orientadora: Ana Luiza D’Ávila Viana.

Descritores: 1.Regionalização 2.Política de saúde 3.Sistema único de saúde 4.Planejamento em saúde 5.Assistência à saúde 6.Brasil

USP/FM/DBD-437/13 


\section{Agradecimentos}

À minha orientadora, Ana Luiza D'Ávila Viana, pelo estímulo intelectual, pelas oportunidades oferecidas e pela generosidade e sabedoria com que conduz as pesquisas e as parcerias acadêmicas.

Aos professores Luciana Dias de Lima, Márcio Cataia e Moises Goldbaum, pelas importantes contribuições durante o exame de qualificação.

À Fabíola Lana Iozzi, pela amizade e parceria profissional e intelectual. À Cristiani Machado, João Henrique Scatena, Hudson P. da Silva, Guilherme Mello, Roberta Gondim, Maria Luiza Levi, Ana Paula Coelho e Adelyne Pereira, pela amizade e parceria profissional. Ao Pablo Ibañez, Virna David e Samuel Frederico pela amizade e parceria nas pesquisas geográficas sobre o tema da saúde.

Ao Edmilson Brito Rodrigues, pela amizade e generosidade com que sempre me acolheu em Belém, nos momentos de realização da pesquisa.

A todas as pessoas que aceitaram participar e colaborar com as pesquisas que subsidiaram esse trabalho, especialmente aos gestores e técnicos federais, estaduais e municipais de saúde.

Aos gestores e técnicos da Secretaria de Ciência, Tecnologia e Insumos Estratégicos e da Secretaria de Gestão Estratégica e Participativa do Ministério da Saúde pela oportunidade de participação no processo recente de mudança das diretrizes nacionais de regionalização do SUS.

Aos docentes, alunos e funcionários do Departamento de Medicina Preventiva da Faculdade de Medicina da Universidade de São Paulo, em especial ao Prof. Paulo Elias (in memoriam), pelo apoio profissional e intelectual, à Stella Maris Nicolau e Camila Monteiro, pela parceria na representação discente, à Camila Silva e Christiane Martins, pela amizade e apoio técnico à pesquisa, e à Lilian Prado, pelo apoio no processo burocrático da pós-graduação. À Mônica Matsumoto, pela parceria na representação discente na Faculdade de Medicina.

À Faculdade de Medicina da Universidade de São Paulo, pela oportunidade de realização do doutorado.

À Coordenação de Aperfeiçoamento de Pessoal de Nível Superior (Capes), pela concessão de bolsa de doutorado e apoio financeiro para a realização da pesquisa.

Aos familiares e amigos, pelo apoio, compreensão e ajuda nos momentos de maior dificuldade, em especial à minha mãe, Maria Elisa, e à Rita e Suzana Albuquerque e ao Fábio Tozi, pela ajuda na revisão final da tese.

Ao Luis Henrique Leandro Ribeiro, pelo amor, companheirismo e parceria intelectual, além do grande apoio, sem o qual seria muito mais difícil a realização e finalização desse trabalho. 


\section{Sumário}

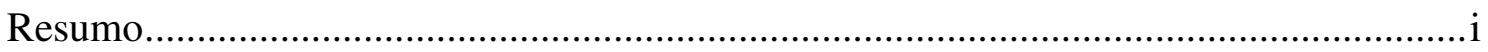

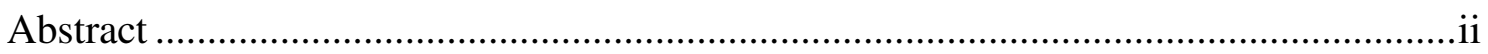

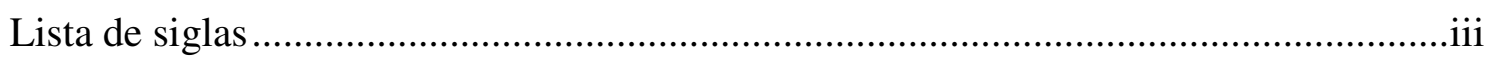

Lista de figuras, gráficos, quadros e tabelas ...........................................................iv

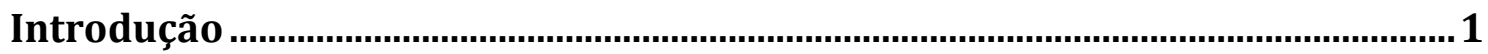

Capítulo 1. Região e regionalização: atualidade dos conceitos e

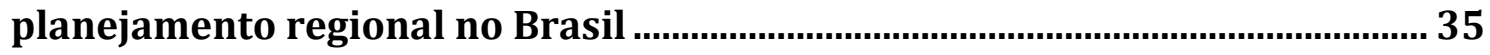

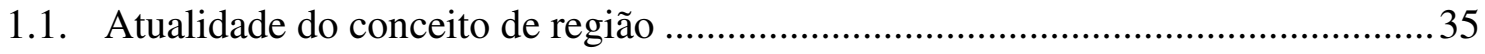

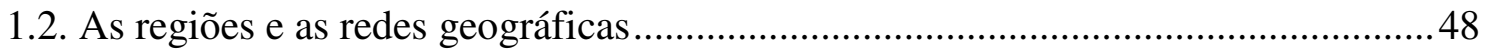

1.3. Regionalização e planejamento regional no Brasil: breve resgate histórico,

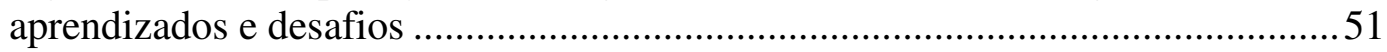

Capítulo 2. 0 enfoque regional nas diretrizes nacionais de planejamento e gestão do Sistema Único de Saúde (2001 - 2011) ................................................ 84

2.1. A "regionalização normativa": Norma Operacional de Assistência à Saúde

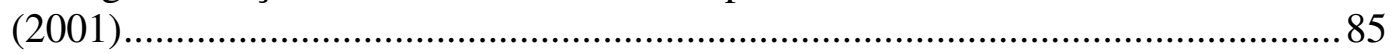

2.2. A "regionalização viva": Pacto pela Saúde (2006) .................................................. 102

2.3. A "regionalização contratualizada": Decreto $n^{\circ} 7.508$ (2011) ................................ 114

Capítulo 3. Redes de atenção à saúde e redes interfederativas como bases técnicas e políticas da regionalização do Sistema Único de Saúde..................138

3.1. As diferentes noções de rede de saúde que influenciaram a política nacional....... 138

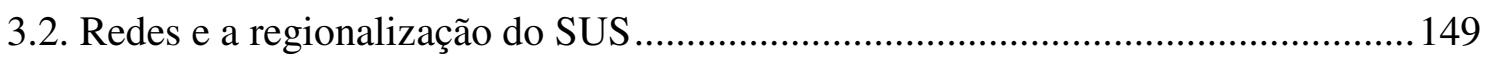

Capítulo 4. Experiência recente de regionalização do Sistema Único de Saúde nos estados brasileiros (2007-2010) .......................................................178

4.1. Amazônia: contextos menos favoráveis, institucionalidade incipiente e intermediária da regionalização do SUS..........................................................207

4.2. Nordeste: contextos mais e menos favoráveis, institucionalidade incipiente a avançada da regionalização do SUS ...........................................................2 215

4.3. Centro-Oeste: contextos mais favoráveis, institucionalidade intermediária e avançada da regionalização do SUS

4.4. Região Concentrada: contextos mais favoráveis, institucionalidade intermediária e avançada da regionalização do SUS .........................................................2232

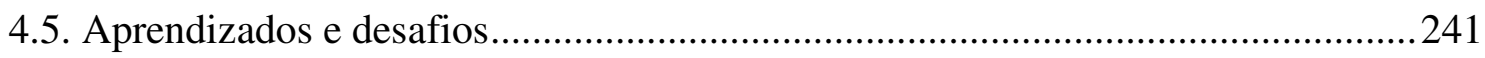

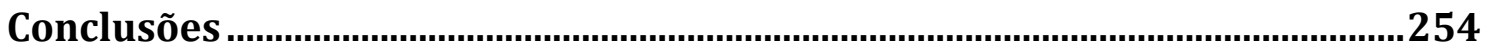

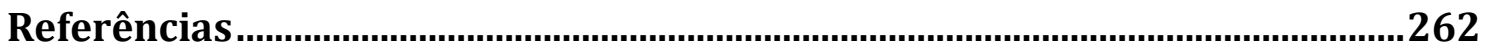




\section{Resumo}

Albuquerque MV. O enfoque regional na política de saúde brasileira (2001-2011): diretrizes nacionais e o processo de regionalização nos estados brasileiros [tese]. São Paulo: Faculdade de Medicina, Universidade de São Paulo; 2013.

O objetivo é analisar o enfoque regional na política de saúde brasileira (2001-2011), considerando as mudanças nas diretrizes nacionais e o processo de regionalização nos estados. Utilizou-se o referencial teórico da geografia humana (geografia nova) e da análise de políticas públicas (institucionalismo histórico), pesquisa bibliográfica sobre o tema, análise de dados secundários, análise documental e entrevistas com atores-chave do processo de regionalização nos estados. Concluiu-se que, em dez anos, o enfoque regional progrediu no sentido de tornar a região de saúde o recorte privilegiado para lidar com a dimensão territorial da universalização da saúde e induzir mudanças na política, no planejamento, financiamento, na gestão e organização técnica do Sistema Único de Saúde (SUS), a fim de assegurar uma ação mais eficaz do Estado na garantia do direito à saúde. As diretrizes nacionais caracterizaram três fases: a "regionalização normativa", a "regionalização viva" e a "regionalização contratualizada". A partir de 2010, a forte associação entre as diretrizes de regionalização e das redes de atenção à saúde tendeu a priorizar o enfoque das redes no planejamento do SUS, tornando mais complexa a ideia de regionalização. Mas a capacidade de induzir mudanças e garantir a universalização a partir das redes e regiões de saúde depende fundamentalmente da conformação do sistema e das políticas de saúde nos estados. As situações geográficas que caracterizam quatro grandes regiões brasileiras (Região Concentrada, Amazônia, Nordeste e Centro-Oeste) associadas à forma de organização política do território criam limitações e especificidades para o planejamento e gestão regional do SUS. A experiência recente de regionalização nos estados (2007-2010) mostrou diferentes estágios desse processo, segundo os contextos (histórico-estrutural, políticoinstitucional e conjuntural), a direcionalidade (ideologia, objeto, atores, estratégias e instrumentos) e as características da regionalização (institucionalidade e governança). A institucionalidade das regiões de saúde tende a ser mais avançada e sua governança mais cooperativa e coordenada nos estados com maior tradição de planejamento regional, onde os contextos são mais favoráveis, onde há priorização da regionalização nas agendas estaduais e municipais de saúde (e/ou dos conselhos de secretários municipais) e forte atuação das secretarias estaduais no planejamento. Os contextos tendem a ser mais favoráveis ao processo de regionalização do SUS nas áreas mais populosas, densamente urbanizadas e modernizadas, concentradoras de tecnologias, profissionais, fluxos materiais e imateriais, equipamentos e recursos públicos e privados de saúde.

Palavras-chave: Regionalização; Política de Saúde; Sistema Único de Saúde; Planejamento em Saúde; Assistência à Saúde. 


\begin{abstract}
Albuquerque MV. The regional focus in Brazilian health policy (2001-2011): national guidelines and the regionalisation process in the states [thesis]. Faculty of Medicine, University of Sao Paulo, SP (Brazil); 2013.

The aim of this study is to analyse the regional focus in Brazilian health policy (2001-2011), considering the changes in national guidelines and the regionalisation process in the states. The theoretical framework was based on human geography (geografia nova) and public policy analysis (historic institutionalism), and the work involved methods including bibliographic research on the topic, secondary data analysis, documental analysis and interviews with key players in the regionalisation process in the states. The conclusion was drawn that in the ten-year period regional focus evolved in the sense that the health region has become the central means for addressing the territorial dimension of universalised health care and inducing changes in the policy, planning, funding, management and technical organisation of the Unified Health System (SUS), in order to ensure more effective State action and guarantee the right to health care. The national guidelines can be classified into three phases: "regulatory regionalisation", "live regionalisation" and "contractual regionalisation". From 2010 onwards, the strong association between the regionalisation guidelines and the health care networks tended to prioritise the networks' focus on SUS planning, making the idea of regionalisation more complex. But the ability to induce changes and ensure universalisation through the health care networks and regions relies fundamentally on the formation of the health system and policies in the states. The geographic situations that characterise the four major Brazilian regions (Concentrated Region, Amazon, Northeast and Central-West) allied to the form of political organisation of the territory create limitations and specificities for the planning and regional management of the SUS. Recent experience of regionalisation in the states (2007-2010) has shown different stages of this process, according to the contexts (historical-structural, political-institutional and state of affairs), the directionality (ideology, scope, actors, strategies and instruments) and the characteristics of the regionalisation (institutionalism and governance). The institutionalism of the health regions tends to be more advanced and its governance more cooperative and coordinated in the states where there is a stronger tradition of regional planning, the contexts are more favourable, regionalisation is prioritised on the state and municipal health agendas (and/or the agendas of the boards of local secretaries) and where the state secretaries play a key role in planning. Contexts that tend to favour the process of regionalisation of the SUS are more populated areas that are densely urbanised and modernised, with a high concentration of technologies, professionals, material and immaterial flows, equipment and public and private resources for health care.
\end{abstract}

Keywords: Regional Health Planning; Health Policy; Unified Health System; Health Planning; Delivery of Health Care. 


\title{
Lista de siglas
}

\author{
APS - Atenção Primária em Saúde \\ BIRD - Banco Internacional para Reconstrução e Desenvolvimento \\ BM - Banco Mundial \\ CIB - Comissão Intergestores Bipartite \\ CIT - Comissão Intergestores Tripartite \\ CIR - Comissão Intergestores Regional \\ CGR - Colegiado de Gestão Regional \\ COAP - Contrato Organizativo da Ação Pública de Saúde
}

DARAS - Departamento/Diretoria de Articulação de Redes de Atenção à Saúde/Ministério da Saúde

FUNAI - Fundação Nacional do Índio

IDSUS - Índice de Desempenho do SUS

MI - Ministério da Integração Nacional

MS - Ministério da Saúde

NOAS - Norma Operacional de Assistência à Saúde

OMS - Organização Mundial da Saúde

ONGs - Organizações Não Governamentais

OPAS - Organização Pan-americana de Saúde

PAS - Plano Saúde Amazônia

PDI - Plano Diretor de Investimentos

PDR - Plano Diretor de Regionalização

PPI - Programação Pactuada e Integrada da Assistência à Saúde

RAS - Redes de Atenção à Saúde

RENAME - Relação Nacional de Medicamentos Essenciais

RENASES - Relação Nacional de Ações e Serviços de Saúde

RIDE - Região Integrada de Desenvolvimento Econômico

RISS - Redes Integradas de Serviços de Saúde

RM - Região Metropolitana

RP - Região Programa

RS - Região Singular

SUS - Sistema Único de Saúde

WHO - World Health Organization 


\section{Lista de figuras, gráficos, quadros e tabelas}

Figura 1 - Qualificação das Microrregiões na Assistência à Saúde nos estados (exemplo)

Figura 2 - Regiões brasileiras no período da globalização.......................................... 192

Figura 3 - Tipologia das regiões de saúde no Brasil (2010)........................................ 195

Figura 4 - Ideologias e objetos predominantes no processo de regionalização da saúde nos estados - Brasil, 2007 a 2010.

Figura 5 - Padrões predominantes de institucionalidade e governança no processo de regionalização da saúde nos estados - Brasil, 2007 a 2010.

Figura 6 - Institucionalidade e capacidade de atuação da Comissão Intergestores Bipartite, por estados- Brasil, 2007- 2010.

Gráfico 1 - Recursos totais destinados para subprojetos QualiSUS-Rede, nas Regiões Metropolitanas selecionadas, segundo macrorregiões (Brasil, 2012).

Gráfico 2 - Recursos totais destinados para subprojetos QualiSUS-Rede, nas Regiões Singulares selecionadas, segundo macrorregiões (Brasil, 2012) ...

Gráfico 3 - Recursos totais destinados para subprojetos QualiSUS-Rede, nas 15 regiões selecionadas, segundo macrorregiões (Brasil, 2012).

Gráfico 4 - Recursos totais destinados para subprojetos QualiSUS-Rede, nas 15 regiões selecionadas, segundo UF (2012).

Gráfico 5 - Despesas dos estados em saúde com recursos próprios, por habitante, segundo a região - 2002/2008 (em R \$ de dezembro de 2009 - IPCA/IBGE)

Gráfico 6 - Despesas dos municípios em saúde com recursos próprios, por habitante, segundo a região - 2002/2008 (em R \$ de dezembro de 2009 - IPCA/IBGE) ... 206

Quadro 1 - Contribuições da Geografia e da Economia para a identificação de regiões 46 Quadro 2 - Planejamento regional no Brasil no contexto das diferentes agendas de desenvolvimento (1930-2011): papel do Estado, conceitos e objetivos.

Quadro 3 - Diretrizes nacionais de regionalização do Sistema Único de Saúde: definições, critérios, objetivos, responsáveis, divisões e instrumentos (Brasil, 20012011)

Quadro 4 - Duas formas de "enxergar" a regionalização do Sistema Único de Saúde: o Pacto pela Saúde e a Portaria 4.279/2010.

Quadro 5 - Diretrizes nacionais para conformação das redes temáticas nas regiões de saúde (Brasil, 2011-2013).

Quadro 6 - Principais eventos relacionados à institucionalização das redes de atenção à saúde na política nacional de saúde $(1990$ - 2012).... 
Quadro 7 - Referencial analítico da pesquisa

Quadro 8 - Contextos, padrões predominantes de institucionalidade e governança, impactos e inovações do processo de regionalização em saúde nos estados, segundo os "quatro Brasis" - 2007 a 2010.

Quadro 9 - Padrão predominante nas relações intergovernamentais no âmbito da Comissão Intergestores Bipartite, seu papel na regionalização e presença deste tema na agenda da CIB, segundo os "quatro Brasis" (Brasil, 2007 a 2009)

Tabela 1 - Regiões Metropolitanas selecionadas para a implantação dos subprojetos QualiSUS-Rede (Brasil, 2012).

Tabela 2 - Regiões Singulares selecionadas para a implantação dos subprojetos

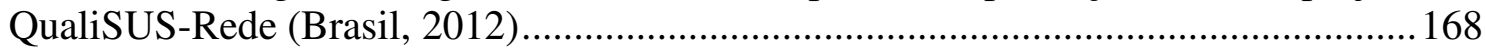

Tabela 3 - Principais características dos agrupamentos das CIR ................................. 194

Tabela 4 - Distribuição da despesa regionalizada do Fundo Nacional de Saúde por grupos de UFs beneficiadas (em percentual do total) - 2002/2008 


\section{Introdução}

O direito universal à saúde está garantido pelo Art.196 da Constituição Federal de 1988, sob a responsabilidade do Estado, através do Sistema Único de Saúde (SUS). Faz vinte e cinco anos que o Brasil se tornou o primeiro país do mundo a instituir um sistema universal de saúde em um território de proporções continentais, marcado por profundas desigualdades socioespaciais e organizado a partir de um sistema federativo que confere autonomia aos estados e municípios.

A universalização da saúde no Brasil dependente muito da forma como o SUS se realiza no território. Isso envolve: (i) a distribuição espacial dos equipamentos, serviços, redes assistenciais, profissionais, tecnologias, informações, fluxos, normas, recursos financeiros, programas e políticas de saúde; (ii) o perfil epidemiológico e as necessidades de acesso e saúde da população em cada lugar; e (iii) as diferentes escalas, responsabilidades e formas de ação do Estado no planejamento, financiamento e na gestão do sistema de saúde.

O conceito de território nos remete ao compartimento espacial da ação do Estado, mas, sobretudo, aos sistemas indissociáveis de objetos e ações que possibilitam seus diversos usos e se impõem como condição para a atuação do Estado, das empresas e da sociedade (SANTOS, 1978, 1996). Trata-se, portanto, de compreender o território usado como sinônimo de espaço geográfico, um espaço banal, isto é, um território vivido e usado por todos, ainda que de forma diversa e desigual quanto ao poder de cada um e de cada instituição para influir sobre esse sistema indissociável de objetos e ações (SANTOS, 1999). O uso do território pode ser definido:

...pela implantação de infraestruturas, para as quais estamos igualmente utilizando a denominação de sistemas de engenharia, mas também pelo dinamismo da economia e da sociedade. São os movimentos da população, a distribuição da agricultura, da indústria e dos serviços, o arcabouço normativo, incluídas a legislação civil, fiscal e financeira, que, juntamente com o alcance e a extensão da cidadania, configuram as funções do novo espaço geográfico. (SANTOS \& SILVEIRA, 2001, p.21). 
O conceito de saúde $^{l}$ nos remete às concepções e aspirações de concretização do bem-estar individual e coletivo, que mudam a cada período, em cada cultura e cada lugar. Concorda-se com Scliar (2007, p.30) quando afirma que o conceito de saúde é mutante:

[...] reflete a conjuntura social, econômica, política e cultural. Ou seja: saúde não representa a mesma coisa para todas as pessoas. Dependerá da época, do lugar, da classe social. Dependerá de valores individuais, dependerá de concepções científicas, religiosas, filosóficas.

A relação entre saúde e espaço geográfico, estudada desde a obra de Hipócrates $^{2}$, precisa ser atualizada a cada período histórico e em cada formação socioespacial ${ }^{3}$. Deve-se considerar o estado das técnicas e das políticas que alimentam o modo de produção vigente, na totalidade do mundo, e sua concretização nas formações socioespaciais, isto é, como os diferentes usos do território condicionam as possibilidades de realização da saúde, enquanto bem-estar social e fonte de acumulação de capital (ALBUQUERQUE, 2006).

\footnotetext{
${ }^{1}$ O termo saúde vem do latim (salus,útis) e significa "salvação e conservação (da vida)" (Houaiss).

2 As primeiras relações entre geografia e saúde foram elaboradas por Hipócrates (Ares, Águas e Lugares, 480 a.C.), que descreveu a influência dos aspectos físicos, como o clima e a água, sobre a saúde humana. A relação entre espaço geográfico e saúde tem sido estudada, desde a obra de Hipócrates, a partir de dois enfoques clássicos, que podem ser resumidos, grosso modo: (i) no enfoque da distribuição dos serviços, tecnologias, recursos financeiros e fluxos assistenciais e do planejamento da rede assistencial em diferentes escalas espaciais e contextos urbanos e rurais; (ii) no enfoque da distribuição espacial dos casos de morbimortalidade e das necessidades em saúde da população no território.

3 "A categoria de formação econômica e social foi elaborada por Marx e Engels (Marx, 18 Brumaire, O Capital; Marx e Engels, L'Idéologie Allemande; Engels, On Social Relations in Rússia, AntiDühring). Lênin retoma o tema utilizando-o para fins científicos e políticos em L'Impôt en espécies, Qui sont les amis du peuple, et Lê Dèveloppement du Capitalisme em Russie. Não se pode esquecer igualmente os estudos de Plékhanov, Nos désaccords, Chayanov, The Theory of Peasant Economy, Kautsky, La Question Agraire." (Santos, 1977, p.82, nota do autor). A categoria de formação econômica e social, proposta dentro do método do materialismo histórico, tem por função expressar as referências de transformação de uma dada sociedade, isto é, de sua evolução diferencial e específica em relação às dimensões sociais e econômicas. Com o objetivo de esclarecer melhor essa categoria, Milton Santos argumenta sobre a necessidade de se fazer a distinção entre modo de produção e formação socioespacial. O modo de produção seria o "gênero", isto é, uma possibilidade de realização, ligado a um modelo explicativo sobre a história das formas criadas a seu serviço; já a formação socioespacial seria a "espécie", isto é, uma possibilidade realizada, ligada a uma realidade concreta, suscetível de localização histórico-temporal, portanto, que tem existência real e historicamente determinada e que só pode ser definida a partir de seu conhecimento. Enquanto o modo de produção escreve a história no tempo, cada formação socioespacial escreve a história no espaço. (Santos, 1977, p.85-88).
} 
No contexto da ordem capitalista global, as concepções individuais e coletivas sobre saúde submetem-se à racionalidade da produção da mais-valia universal $^{4}$ (SANTOS, 2000), que coloca a realização da saúde como uma das mais importantes fontes de acumulação de capital (GADELHA \& COSTA, 2012). As concepções de saúde coletiva e individual estão cada vez mais intimamente associadas às possibilidades de usufruto das tecnologias, conhecimentos científicos e informações produzidos no âmbito dessa ordem (SABROZA, 2005; ALMEIDA, 2005).

As possibilidades de realização da saúde expressam desigualdades sociais, econômicas e regionais. Existem índices alarmantes quanto às desigualdades de concretização do bem-estar nos diferentes lugares do mundo. "Tudo o que o 'progresso' anunciava aí está e, nem por isso a felicidade e o 'saudável' estão presentes para a maioria das pessoas vivas do planeta" (SOUZA, 2004, p.61).

A divisão internacional do trabalho na globalização e a força da lógica privada de organização do sistema de saúde no Brasil, com base no desenvolvimento científico e na difusão tecnológica, impõem novas demandas e atualizam as desigualdades regionais em saúde (ALMEIDA, 2005). A cada nova divisão internacional do trabalho muda o valor e o papel dos lugares nessa divisão, e a conformação do sistema de saúde acompanha esses movimentos, seus recursos, serviços e profissionais concentram-se nos lugares mais valorizados pelas sucessivas modernizações (ALBUQUERQUE, 2006).

No Brasil, o direito universal à saúde não se efetiva igualmente em todos os lugares, pois o SUS se concretiza de maneira incompleta e seletiva no território, em geral, seguindo as tendências regionais de concentração e escassez populacional, econômica e das modernizações técnicas, científicas e informacionais, que

\footnotetext{
${ }^{4}$ A partir da segunda metade do século XX, a expansão do meio técnico-científico-informacional pelo planeta difundiu os usos do território que mantêm a "unicidade do motor" de funcionamento dessa ordem global: "Hoje haveria um motor único que é, exatamente, a mencionada mais-valia universal. Esta tornou-se possível porque a partir de agora a produção se dá à escala mundial, por intermédio de empresas mundiais, que competem entre si segundo uma concorrência extremamente feroz, como jamais existiu. As que resistem e sobrevivem são aquelas que obtêm a mais-valia maior, permitindose, assim, continuar a proceder e a competir. Esse motor único se tornou possível porque nos encontramos em um novo patamar de internacionalização, com uma verdadeira mundialização do produto, do dinheiro, do crédito, da dívida, do consumo, da informação. Esse conjunto de mundializações, uma sustentando e arrastando a outra, impondo-se mutuamente, é também um fato novo". (SANTOS, 2000, p.29-30).
} 
caracterizam o meio geográfico (ALMEIDA, 2005). Os lugares e regiões mais empobrecidos e menos atrativos para o grande capital são também aqueles que apresentam menor atratividade e capacidade de investimentos na saúde, maiores dificuldades de atração e fixação de profissionais de saúde, menor capacidade de oferta assistencial pública e privada e maiores dificuldades relacionadas à gestão, ao financiamento e planejamento do SUS (ALMEIDA, 2005; OLIVEIRA, 2005, ALBUQUERQUE, 2006; VIANA ET AL., 2007; VIANA \& LIMA, 2011).

Além das restrições políticas e financeiras que marcaram a implantação do SUS (MACHADO, 2013), acrescenta-se também aquela imposta pela dimensão territorial do processo de universalização da saúde. As desigualdades relacionadas aos usos do território impõem limitações para as políticas de saúde e para a expansão do sistema, porque resultam em situações de grande concentração e rarefação espacial das tecnologias, dos recursos e equipamentos assistenciais do SUS.

A conformação do SUS no território reflete uma tensão entre a capacidade das políticas de saúde para criarem estratégias de enfrentamento das desigualdades socioespaciais, garantindo o acesso universal ao sistema para toda população, e a força do mercado econômico da saúde para influir nos padrões de desenvolvimento tecnológico e difusão espacial das inovações, equipamentos, recursos e serviços de saúde.

A dimensão territorial da universalização da saúde no Brasil compreende o processo de expansão e conformação do SUS como um sistema indissociável de equipamentos e ações assistenciais, que combina, em cada lugar, diferentes tecnologias, conhecimentos científicos, normas, fluxos materiais e imateriais (informação), necessidades de saúde, recursos financeiros, políticas, programas, profissionais, usuários e instituições públicas e privadas. A dimensão territorial da universalização da saúde abrange aspectos técnicos e políticos da conformação do sistema e das políticas de saúde e coloca algumas questões importantes para as políticas de saúde. Primeiro: como criar estratégias para o enfrentamento das desigualdades regionais no que se refere às condições de acesso aos serviços e tecnologias assistenciais e às capacidades de gestão, financiamento e planejamento do sistema por parte dos estados e municípios, de forma a garantir o direito universal para todos os cidadãos, em todos os lugares? Segundo: como incorporar as 
diversidades regionais em relação às possibilidades de existência de ações e serviços assistenciais e às necessidades de saúde da população? Terceiro: como coordenar as ações de gestão, financiamento e planejamento executadas pelos três entes federados, de forma a construir um sistema único e universal de saúde cuja lógica de funcionamento abrange diferentes escalas espaciais, ultrapassando limites municipais e estaduais?

Nos últimos vinte e cinco anos, o território usado não foi objeto principal da política nacional para a implantação do SUS, expressando uma fragilidade na diversificação de políticas e investimentos que relacionassem melhor as necessidades de saúde às dinâmicas territoriais, visando à redução das desigualdades em diferentes planos (VIANA et. AL., 2007, 2011).

A estratégia que mais se aproximou da lida com a dimensão territorial da universalização da saúde, no âmbito da política nacional, foi a da organização de regiões de saúde nos estados. Pode-se apontar como objetivos centrais da regionalização do SUS: (i) organizar redes assistenciais hierarquizadas e regionalizadas; (ii) promover negociações e relações intergovernamentais mais cooperativas e coordenadas e o planejamento integrado nas regiões de saúde; (iii) valorizar o papel dos estados no planejamento; (iv) diminuir as desigualdades socioespaciais no acesso aos sistema de saúde; e (v) incorporar as diversidades regionais nas políticas de saúde.

Princípio organizativo do Sistema Único de Saúde (SUS) previsto na Constituição Federal e na Lei Orgânica da Saúde (Brasil, 1988; 1990), a regionalização da assistência à saúde deve ser instituída pelos estados em articulação com os municípios.

Trata-se de uma regionalização setorial, exclusiva da política de saúde, baseada nas características da produção, organização, financiamento, gestão e uso dos serviços e ações do Sistema Único de Saúde no território, portanto, uma regionalização do SUS. Os recortes das regiões de saúde fundamentam-se no agrupamento de municípios limítrofes, que compartilham redes e fluxos assistenciais, uma determinada capacidade resolutiva assistencial e um dado perfil epidemiológico da população usuária, e assemelham-se quanto às características culturais, socioeconômicas e de integração regional (redes de transporte e comunicação). Os 
municípios e representantes estaduais devem negociar metas e os objetivos assistenciais regionais.

A regionalização do SUS é uma prática necessária porque no limite de um único município raramente existe uma capacidade instalada assistencial que garanta a resolução de todas as demandas de saúde da população residente, sendo indispensável integrar as ações e serviços de saúde em redes assistenciais regionalizadas e hierarquizadas, construídas a partir da relação solidária entre os três entes federados. Como a União, os estados e os municípios são os responsáveis pela oferta, gestão, financiamento e planejamento das ações e serviços do SUS, a construção das redes assistenciais regionais depende da capacidade de cooperação intergovernamental em torno das lógicas de conformação do SUS no território.

Apesar de constar como princípio organizativo do SUS desde o início de sua construção, a estratégia da regionalização da saúde só começou a ser delineada nas diretrizes nacionais a partir dos anos 2000. As experiências estaduais e municipais de descentralização e regionalização das redes assistenciais de saúde, que inclusive inspiraram o projeto da Reforma Sanitária, não foram suficientes para estimular a regionalização do SUS já na década de 1990.

Assim, ao longo do século XX, antes da criação do SUS, as políticas nacionais de saúde trabalharam a dimensão territorial a partir de dois enfoques principais: (i) o da descentralização política e administrativa nos estados, incluindo a estruturação de redes assistenciais regionais; e (ii) o enfoque da relação entre desenvolvimento econômico urbano, rural e regional e as condições de vida e saúde da população, definindo estratégias de intervenção específicas para cada caso, no âmbito da política nacional de saúde.

Durante a Primeira República (1889-1930), a estruturação de uma política nacional de saúde pública ocorreu paralelamente à criação e reorganização de órgãos estaduais responsáveis pela elaboração e execução de políticas de saúde. Nessa fase, a responsabilidade pelas ações de saúde e saneamento cabia aos estados (Constituição Federal de 1891), que organizaram seus sistemas, sendo que alguns até criaram uma regionalização administrativa (a exemplo da Bahia ${ }^{5}$, tratado por Araújo,

5 “[Na virada do século XX] Mesmo aqueles que haviam desfrutado posição política de destaque, como a Bahia que, ademais, se sobressaiu na própria história da medicina, ficaram em nítida 
1973). A maioria dos estados, muito confusos quanto ao projeto da administração e com dificuldades para a execução das ações de saúde, sofreram intervenção sanitária da União (SANTOS, 1998; HOCHMAN, 2006, p.211). A exceção foi São Paulo, que acabou servindo de exemplo para as outras unidades da federação em termos de estruturação da política estadual de saúde, mesmo para estados como Rio de Janeiro e Bahia (SANTOS, 1998; HOCHMAN, 2006). São Paulo contava com o apoio das elites locais para que a política de saúde auxiliasse o desenvolvimento da economia cafeeira, controlando epidemias devastadoras nas áreas urbanas e no porto de Santos e, ao mesmo tempo, construísse uma base estadual de pesquisa e produção técnicocientífica em saúde, que contribuíra para a autonomia da política paulista (HOCHMAN, 2006).

$\mathrm{Na}$ virada do século $\mathrm{XX}$, duas correntes internacionais concorreram para influenciar a política de saúde brasileira e suas estratégias para lidar com a dimensão territorial da saúde: uma europeia, que marcou a primeira reforma sanitária no estado do Rio de Janeiro; e outra norte-americana, que marcou a forma de organização dos serviços assistenciais no estado de São Paulo.

O ideário europeu de desenvolvimento ${ }^{6}$, que estava ligado aos avanços do conhecimento técnico e científico, da industrialização e da urbanização, foi traduzido para a saúde através dos estudos da higiene, que relacionavam o intenso processo de transformação das sociedades com as condições de saúde (LIMA, 2002). A epidemia de febre amarela no Rio de Janeiro, em meados do século XIX, alterou sensivelmente a imagem pública do Brasil, que prevalecia a ideia de "um mundo sem mal" (Ibidem, 2002, p.38). Iniciou-se o período das primeiras reformas urbanas, da busca de sua europeização ${ }^{7}$, seguindo principalmente o modelo da Paris de Haussman

desvantagem em relação aos progressos de São Paulo.” (CASTRO SANTOS, 1998). Em 1925, já havia uma proposta de organização regional dos serviços de saúde no estado da Bahia, mas era confusa e foi reformulada com base na experiência paulista (ARAÚJO, 1973).

${ }^{6}$ No Brasil, sob a influência desse ideário, houve uma modernização dependente (exportação de produtos primários; imitação de padrões de comportamento social; e distanciamento entre a elite e o povo ) que, desde a primeira metade do século XIX, "cimentou-se o subdesenvolvimento e as disparidades regionais de níveis de vida” (FURTADO, 1999, p.107).

${ }^{7}$ Em 1851, tem início a organização das Conferências Sanitárias Internacionais na Europa. Eram fóruns de debate científico sobre as controvérsias em torno das causas e mecanismos de transmissão de doenças, e político, uma vez que se tratava de estabelecer normas e procedimentos comuns entre os países que enfrentavam problemas como as epidemias de cólera e de peste bubônica. Essas conferências reuniam basicamente países europeus e expressavam a contradição entre a crescente insegurança - em face da ampliação das epidemias e da própria emergência do conceito de pandemia 
(BENCHIMOL, 1990A,B). As Reformas Urbanas que acompanharam as intervenções sanitárias tinham como referência o planejamento francês de origem renascentista, caracterizado pela expressão embelezamento urbano; esta concepção traduzia os anseios civilizatórios da classe dominante e embasou o planejamento brasileiro desde a sua origem, em 1875, até a década de 1940 (VILAÇA, 2004).

A Primeira Reforma Sanitária (1903) focou na crítica à oligarquização do país e à ausência de uma ação coordenada em nível nacional. O movimento sanitário ganhou força ideológica ao se vincular à construção da nacionalidade brasileira, mas era fundamental convencer as elites a olhar para o interior do país ${ }^{8}$, para o "sertão", para garantir ganhos políticos a partir da crescente intervenção estatal no território, rompendo os "regionalismos" das oligarquias rurais (CASTRO SANTOS, 1985). As ações de saúde dividiram-se entre áreas urbanas, no combate de epidemias urbanas, e áreas rurais, com o saneamento rural e dos sertões (CASTRO SANTOS, 1985), com base na força das ideias nacionalistas daquele momento (LIMA, 2002). As reformas sanitárias contribuíram para consolidar o Estado Nacional no Brasil, na medida em que relacionavam as possibilidades de expansão territorial da autoridade pública ao

- e a ideia de progresso que se afirmava e encontrava representação simbólica nas Grandes Exposições Internacionais. (LIMA, 2002, p.36). Sugestivamente, a primeira Conferência Sanitária e a primeira Exposição Internacional ocorreram no mesmo ano, 1851, respectivamente em Paris e Londres. (WHO, 1958 citado por LIMA, 2002: 36).

8 "Parece-me que o movimento sanitário representou um canal dos mais importantes na República Velha para o projeto ideológico de construção da nacionalidade. A ligação saúde pública \& nacionalidade é talvez o traço mais distintivo do movimento sanitário brasileiro em relação ao europeu e norte-americano. Como se estabelece a relação mencionada? Cabe aqui retomar alguns pontos sugeridos anteriormente. Viu-se que até por volta de 1915, a suposta incapacidade racial do brasileiro era considerada uma pedra no caminho da modernização. A vinda de sangue novo com o imigrante europeu representava o mais importante trunfo das elites para a desejada salvação nacional. Ora, a queda da imigração europeia durante a primeira guerra mundial abriu caminho para propostas alternativas. Ademais, mesmo nos anos de forte imigração, só os estados meridionais se beneficiavam da entrada de europeus. Os sanitaristas acenavam com uma proposta que atraia não só as elites do sul como as do norte. Nosso atraso, diziam, se devia à doença, não ao determinismo biológico. A construção da nacionalidade exigia que as elites desviassem os olhos sempre postos na Europa para o interior do Brasil, para as grandes endemias dos sertões. A (re)integração dos sertões à civilização do litoral representava o grande desafio para o fortalecimento da nacionalidade, pois população doente = raça fraca = nação sem futuro." (CASTRO SANTOS, 1985, p.11).

9"A partir da publicação do Relatório Neiva-Pena [1916], o movimento sanitarista superou sua fase urbana, com a nova bandeira do "saneamento dos sertões". Ressalte-se que o Relatório era o resultado de expedição solicitada por um organismo federal a outra instituição também federal, para atuar em municípios em que o coronelismo alcançava sua expressão máxima no país. A missão do Instituto Oswaldo Cruz plantou a semente da ação do poder central nos estados do nordeste". (CASTRO SANTOS, 1985, p.07). Ver também Sá. 1917 - publicação de uma série de artigos de Belisário Penna no jornal Correio da Manhã (reunidos posteriormente no livro Saneamento do Brasil de 1918). A campanha pela reforma da saúde pública e pelo saneamento dos sertões alcançou repercussão nacional com essa publicação (LIMA, 2002:40). 
progresso técnico-científico de combate às epidemias (HOCHMAN, 2006). As ações de saúde como referência do progresso técnico-científico e da autoridade pública, vislumbram a modernização sanitária do território nas "regiões atrasadas" (rurais) e naquelas de maior dinamismo econômico (urbanas), contribuindo para a formação da nação brasileira e para o aumento da acumulação de capital.

A "questão nordestina" aparece nesse momento associada ao atraso nacional, revelando um sertão doente e abandonado pelo poder público (LIMA, 2002, CASTRO SANTOS, 1985; LIMA ET AL, 2005). Pode-se afirmar também que a “questão Amazônica" começa a ser delineada nesse período, por conta do foco das políticas de saúde nas áreas produtoras e exportadoras da borracha e de expansão das ferrovias, que sofriam com endemias de malária e febre amarela. Mas, a Amazônia só entrou efetivamente como questão regional para o planejamento econômico e para a política de saúde a partir da década de 1940, durante o governo Vargas.

As políticas de saúde colaboraram, nesse período, para a maior penetração do Estado na sociedade e no território brasileiro (LIMA et al, 2005). Em 1920, foi criado o Departamento Nacional de Saúde Pública (DNSP), mas a pressão das oligarquias rurais para a manutenção das autonomias estaduais dificultou a criação de um Ministério da Saúde (LIMA et al, 2005). O DNPS estabeleceu uma série de convênios com os estados, para auxiliá-los nas ações de saúde e saneamento, que "viabilizaram a ação do poder central nos estados, sem ferir suas respectivas autonomias", favorecendo o crescimento dessas atividades em todo o território nacional (HOCHMAN, 2006, p.40).

Nessa fase, o ideário americano de desenvolvimento foi traduzido nas políticas de saúde através das ações da Fundação Rockfeller ${ }^{10}$. Em suas duas principais frentes de atuação - os programas de vacinação e a organização dos centros de saúde - a Fundação Rockfeller ditava uma ideologia de desenvolvimento amparada pelas ações públicas de saúde (FAPESP, 2012).

A Fundação Rockfeller, que já havia iniciado suas "expedições sanitárias" pela América Latina em 1915 (VARGA, 2007) e aproveitou a expansão do

\footnotetext{
10 A Fundação Rockefeller foi criada em 1913, nos Estados Unidos da América, para promover, no exterior, sobretudo nos países subdesenvolvidos, o estímulo à saúde pública, o ensino, a pesquisa e a filantropia. É caracterizada como associação beneficente e não-governamental, que utiliza recursos próprios para realizar suas ações em vários países.
} 
movimento sanitarista no interior do Brasil e a crescente intervenção estatal para iniciar sua forte influência na política nacional e nas políticas estaduais, através de seus programas de prevenção e vacinação contra doenças tropicais transmissíveis e da instalação de seus Centros de Saúde.

O novo código sanitário (1920) deu maiores poderes ao governo federal para intervir nos estados. Em poucos meses, onze estados haviam firmado acordos com o governo central para a criação de postos de profilaxia no interior. Sete estados eram da região norte e nordeste. Em 1922, perto de 100 postos de saúde estavam operando, além dos postos abertos pela International Health Commission da Fundação Rockefeller. (CASTRO SANTOS, 1985, p.12).

As intervenções federais nos estados resultavam em convênios com a Fundação Rockfeller para execução de campanhas de vacinação e tratamento de doenças infecciosas, tais como malária e febre amarela (CASTRO SANTOS, 1985). Em São Paulo, a Fundação Rockfeller introduziu novos conceitos sobre os serviços assistenciais e a organização regional da assistência, através da ideia de Centro de Saúde, que tinha como objetivos: a educação sanitária e a prevenção de doenças transmissíveis, orientados através do trabalho médico em tempo integral, foco familiar, exames periódicos, visitas domiciliares, atenção materno-infantil, vacinação e vigilância sanitária (MELLO, 2010; MELLO et al., 2011).

A concepção norte-americana preventiva e de educação sanitária, propagada pela Fundação Rockfeller, acabou influenciando definitivamente ${ }^{11}$ organização dos serviços de saúde no Brasil, conforme apontam Mello et. al (2011). No que se refere à organização regional do sistema de saúde, o Centro de Saúde e a população por ele atendida serviam como referências para a delimitação de áreas administrativas e de planejamento da assistência, isto é, dos Distritos Sanitários ${ }^{12}$.

\footnotetext{
11 "Essa fase tem seu marco inicial bem definido na Reforma do Serviço Sanitário de 1925 (São Paulo, 1925), proposta baseada no moderno referencial norte-americano dos Centros de Saúde distritais trazido a São Paulo por Geraldo de Paula Souza e Francisco Borıges Vieira - valores apreendidos como bolsistas da Fundação Rockefeller em Johns Hopkins (CANDEIAS, 1984; SANTOS E FARIA, 2002). O novo pensamento representava uma drástica e traumática ruptura com o conhecimento da organização sanitária da escola francesa, orgulhoso de seu papel no saneamento das cidades e de toda simbologia representada pelo seu patrono Oswaldo Cruz (em São Paulo também Emílio Ribas)". Mello et. al (2011, p.855).

12 BARRETO, João de Barros; FONTENELLE, José Paranhos. O systema dos centros de saúde no Rio de Janeiro. Archivos de Hygiene, Rio de Janeiro, v.5, n.1, p.83-115. 1935. APUD Mello et al, 2011.
} 
O Estado de São Paulo ajudou a propagar no Brasil o modelo dos centros de saúde distritais para a organização regional dos serviços assistenciais, que até a década de 1940 tinha um cunho eminentemente administrativo e organizativo (MELLO, 2010). Tratava-se de uma regionalização para fins de eficiência administrativa e de vigilância epidemiológica, subsidiada pela racionalidade burocrática sanitária, com organização centralizada, hierarquizada e eminentemente técnica, focada nos conceitos de coordenação e integração dos serviços a partir dos Centros de Saúde (MELLO et al, 2011). A estruturação de serviços locais e regionais integrados era compreendida como uma "descentralização" (desconcentração) a partir dos Centros de Saúde, tirando o foco da regionalização e da primazia política sobre a técnica na organização do sistema (MELLO et al., 2011).

Entre 1930 e 1945, no contexto do Estado Novo, o movimento sanitarista perde força no Brasil com o aprofundamento da centralização e burocratização da política (FONSECA, 2007). Nessa fase, a política nacional de saúde adota outras estratégias para lidar com a dimensão territorial da saúde no país, vinculada às áreas de expansão econômica:

...o período varguista desloca o projeto de construção da nacionalidade dos sertões para a fronteira, em manobra que poupa o novo regime do enfrentamento com as oligarquias do grande sertão. A invenção da fronteira durante a época de Vargas foi o segundo fator responsável pelo fim do movimento sanitarista ${ }^{13}$. (CASTRO SANTOS, 1985, p.17).

O Governo Vargas criou, em 1942, o Serviço Especial de Saúde Pública $(\mathrm{SESP})^{14}$ conferindo um novo método de intervenção regional da política de saúde, focalizado ações federais em áreas estratégicas para a economia, para a segurança e a

\footnotetext{
13 "Primeiramente, a burocratização teve um efeito paralisante sobre o movimento [sanitarista]. A criação do Ministério da Educação e Saúde Pública, em 1930, retira da bandeira da reforma sanitária sua força ideológica e transforma-a - para usar expressão corrente nos dias de hoje - em projeto governamental." (CASTRO SANTOS, 1985, p.17). Ao mesmo tempo, "Nas áreas de antiga dominação coronelista, Vargas praticou uma política de acomodação, de concessões e barganhas. Essa política, em última análise, impediu o avanço do movimento sanitarista nas terras sob domínio oligárquico." (CASTRO SANTOS, 1985, p.18).

${ }^{14}$ Conforme consta da alínea a) do artigo $2^{\circ}$ de seus Estatutos: “organizar e operar serviços de saúde pública e assistência médico hospitalar nas áreas do território nacional onde se desenvolvem ou venham a se desenvolver programas de valorização econômica, sempre que tais serviços não constem dos programas de órgãos federais" (BASTOS, 1996, p. 491).
} 
integração nacional ${ }^{15}$. Além disso, criou um serviço de estatística nacional que centralizou a produção de informações sobre as condições econômicas e sociais no território nacional, diminuindo de certa forma o poder de produção dessas informações a partir dos estados e dos relatórios de viagens científicas elaborados pelos articuladores do movimento sanitarista. Criticava-se o papel das oligarquias regionais em nome do interesse nacional.

Durante seu primeiro governo, o aparato estatal em saúde foi fortalecido, institucionalizando um modelo de saúde verticalizado, setorializado e centralizado (LIMA et al, 2005), caracterizado pelo predomínio de campanhas sanitárias nacionais (HAMILTON \& FONSECA, 2003). Paralelamente, o Governo Vargas adotou políticas sociais específicas para os grandes centros urbanos, procurando atenuar as forças sindicalistas (CASTRO SANTOS, 1985). O sistema nacional de proteção social em saúde ${ }^{16}$ se ampliou atrelado às relações e direitos trabalhistas (legislação trabalhista e sindical) e de educação e saúde (Constituição Federal de 1937). Baseado em uma visão restrita de cidadania regulada, a incorporação dos direitos sociais entre as diversas classes profissionais se dava de maneira fragmentada, corporativa e diversificada, sendo mais efetiva para as classes mais organizadas e inseridas no processo de modernização econômica (SANTOS W., 1989). O tema e os pontos tratados durante a $1^{\text {a }}$ Conferência Nacional de Saúde ${ }^{17}$,

\footnotetext{
15 “O período varguista adotou um critério econômico de combate às endemias. Por exemplo: o desenvolvimento da mineração no vale do Rio doce exigia o saneamento da área a ser explorada. Vargas determina então que um Serviço Especial de Saúde Pública realize o saneamento da região, em 1942. No mesmo ano, o SESP desenvolve atividades de saneamento em áreas de importância estratégica na Amazônia, dado 'o interesse momentâneo que a guerra criara pela borracha'. (CASTRO SANTOS, 1985, p.16; CAMPOS, 2006; ANDRADE, 2007).

${ }^{16}$ Em 1923, a Lei Eloi Chavez regulamentou a criação das Caixas de Aposentadorias e Pensões. Este fato aponta "o momento inicial da responsabilização do Estado pela regulação da concessão de benefícios e serviços, especialmente da assistência médica. Tratava-se de organizações de direito privado, criadas para grupos específicos de servidores públicos e organizadas segundo princípios de seguro social, ou seja, um modelo em que os benefícios dependiam das contribuições dos segurados." (LIMA ET AL, 2005, p.32).

17 Tema da Conferência: Situação sanitária e assistencial dos estados. Suas finalidades foram: a) Estudar as bases da organização de um programa nacional de saúde e de um programa nacional de proteção da infância, síntese dos objetivos a serem atingidos e dos meios a serem mobilizados, nesses dois terrenos do serviço público nacional; b) Estudar e definir o sistema de organização e de administração sanitárias e assistenciais, nas órbitas estadual e municipal; c) Considerar, de modo especial, as campanhas nacionais contra a lepra e tuberculose, para o fim de serem assentadas medidas relativas à sua coordenação e intensificação, e bem assim a situação das cidades e vilas de todo o país quanto à montagem e funcionamento dos serviços de águas e esgotos.
} 
realizada em 1941, ajudam a ilustrar o peso da centralização federal sobre os rumos e diretrizes da política de saúde.

A partir de meados do século XX, as grandes transformações políticas, econômicas e sociais que marcaram o mundo após a Segunda Guerra, repercutiram fortemente na política de saúde brasileira e em suas estratégias territoriais.

No contexto internacional, surgiu um intenso debate sobre a relação entre saúde e desenvolvimento. A Organização Mundial de Saúde (OMS) definiu o conceito de saúde para além da "ausência de doenças", tratando-o "como um estado de completo bem-estar físico, mental e social" (Constituição da OMS, 1948). Os Estados de Bem-Estar Social (Welfare States) europeus e as políticas de saúde em países socialistas indicavam caminhos diversos para a construção de sistemas nacionais de proteção social em saúde. Mas, nas disputas entre os modelos capitalista e comunista, as agências internacionais mostravam a saúde como variável dependente do desenvolvimento econômico e a política de saúde como instrumento de fortalecimento do sistema capitalista e do desenvolvimento.

A emergência do Welfare State nos países europeus, no pós-guerra, revalorizou a política social numa perspectiva de reconstrução econômica, moral e política, visando ampliar os direitos de cidadania no âmbito do desenvolvimento econômico, baseado na industrialização, na urbanização, no pleno emprego e na defesa das ideias de justiça social, solidariedade, integração social e universalismo (ESPING-ANDERSEN, 1995). Ao mesmo tempo, a relação entre saúde e desenvolvimento econômico se baseava no uso do poder de compra do Estado para incentivar as indústrias nacionais (Inglaterra, França e Alemanha) (SILVA, H., 2007) e na estratégia de aquisição de laboratórios e empresas farmacêuticas nos países pobres, para a entrada dos capitais estrangeiros e novas tecnologias nestes países ${ }^{18}$, aproveitando as inovações atreladas à indústria da guerra (CORDEIRO, 1985; TEMPORÃO; 1986).

Em 1952, realizou-se a $5^{\text {a }}$ Assembleia Mundial da Saúde cujo tema era: $o$ valor econômico da saúde. Nesta oportunidade, foram discutidas questões técnicas

\footnotetext{
${ }^{18}$ No Brasil, a indústria nacional farmacêutica e os laboratórios oficiais que até a década de 1930 competiam igualmente com as indústrias estrangeiras, tendo um caráter estratégico vinculado à economia nacional, perderam essa posição no pós-II Guerra, com as privatizações e aquisições pelo capital internacional (CORDEIRO, 1985).
} 
sobre "The Economic Value of Preventive Medicine" e "The Methodology of Health Protection for Local Areas", sob o comando de Winslow ${ }^{19}$, da saúde pública, e de $\mathrm{Myrdal}^{20}$, da economia e secretário executivo da Comissão Econômica para a Europa (BONFIM, 1998, p.298). Nessa ocasião, foi apresentado o trabalho "Economic value of health" produzido por Paulo de Assis Ribeiro, Manoel José Ferreira e Ernani Braga, publicado pelo SESP em 1952. O objetivo deste estudo ${ }^{21}$ era esclarecer o valor econômico da saúde, considerando que as más condições sanitárias implicavam custos elevados para a produção, ao afetarem o rendimento da força de trabalho, e desequilíbrios no crescimento do consumo no mercado interno, criando um obstáculo para a modernização e o desenvolvimento econômico dos países (RIBEIRO, FERREIRA \& BRAGA, 1998). Tratavam-se dos "custos da doença" e dos "custos da morte" para o processo de acumulação de capital e para os sistemas públicos de saúde.

Além disso, o estudo enfatizava que os avanços técnicos e científicos na saúde, como a descoberta do antibiótico, ajudavam a equipar e a melhorar a resposta dos sistemas públicos de saúde aos problemas de saúde da população. Apontava dois aspectos inter-relacionados e centrais no combate à morbimortalidade através dos sistemas públicos de saúde: o saneamento e o controle de doenças transmissíveis. Contudo, indicava também que as transições demográfica (urbanização) e

19 “Charles Edward Amory Winslow (1877-1957). Segundo George Rosen (Uma História da Saúde Pública, $2^{\text {a }}$ ed., Hucitec- Editora Unesp-Abrasco, 1998) "Um líder da Saúde Pública, nos Estados Unidos e no mundo, verdadeiramente insigne. Entre os campos em que trabalhou se incluem a prática da Saúde Pública, a organização da atenção médica, a história da saúde pública e a saúde internacional. Ativo como professor, editor e autor, deixou uma impressão duradoura na Saúde Pública americana". Escreveu, entre outros, The Evolution and Significance of the Modern Public Health Campaign (New Haven, Connecticut: Yale University Press; 1923)" (BONFIM, 1998, p.300).

20 "Karl Gunnar Myrdal (1898-1987). Economista, sociólogo e político sueco; vencedor, com Hayek, do Prêmio Nobel de Eco-nomia, em 1974. Criou a teoria da causação circular, segundo a qual o círculo vicioso do atraso e da pobreza pode ser rompido pela aplicação planejada de reformas que provoquem modificações cumulativas e direcionadas no círculo de causas responsáveis pelas desigualdades econômico-sociais. Foi ministro do Comércio da Suécia (1945-1947) e assessor econômico da ONU para a Europa (1947-1957). Entre outras obras escreveu Teoria Econômica e Regiões Subdesenvolvidas (1957, no Brasil, $3^{a}$ edição, Rio de Janeiro: Saga; 1972), Desafio à Riqueza (1963), Aspectos Políticos da Teoria Econômica (no Brasil, $1^{\mathrm{a}}$ edição, São Paulo: Abril Cultural, 1984), e O Desafio do Mundo Pobre (1970).” (BONFIM, 1998, p.301).

21 "The purpose of this study is to explain the value of health from the viewpoint of the expenses and losses caused by disease and other physical deficiencies which, in all age groups, reduce or hinder the full normal productiveness of the healthy man in a specific period; also losses in productivityresulting from premature deaths and causing a reduction in the number of individuals in each age group in ages below the normal age of Lexis for the region under consideration - throughout the period between the age when death occurred and the respective normal Lexis ages." (RIBEIRO, FERREIRA \& BRAGA, 1998, p.305). 
epidemiológica (crescimento de doenças degenerativas e decrescimento das transmissíveis) que se anunciavam para o mundo também resultariam numa especialização maior dos sistemas de saúde públicos - para cada tipo ou estágio da doença, um tipo de serviço e de tecnologia. Assim, os indicadores de saúde passam a identificar regiões mais ou menos ricas, industrializadas, urbanizadas e desenvolvidas.

Havia um caráter ideológico e emergencial no objetivo de combater as doenças, atrelado à concepção de saúde como questão econômica que implicava perdas para a acumulação de capital (PENA, 1977). Como afirmam Braga \& Paula (1981:01):

...ao longo da história do capitalismo, a questão da saúde não só cresce como problema coletivo, como também ganha espaço no pensamento econômico-social. Observa-se, entretanto, que tal avanço 'teórico' se dá não exatamente na medida em que aumenta a gravidade do problema da saúde coletiva, mas na proporção em que a atenção à saúde passa a ser um problema político e econômico no interior de cada estrutura sócioeconômica concreta.

No Brasil, entre as décadas de 1950-60, travou-se um importante debate sobre a relação entre saúde e desenvolvimento, embasado por discussões internacionais e nacionais e pelas grandes mudanças nos usos do território. A aceleração da industrialização e da urbanização brasileira resultou nas transições demográfica (crescimento da população urbana) e epidemiológica (diminuição da incidência de doenças transmissíveis e o aumento da morbimortalidade por doenças crônicodegenerativas), como resultado, dentre outras coisas, do maior acesso da população urbana às tecnologias e serviços médicos e sanitários. Ao mesmo tempo, a modernização do território não reverteu o quadro histórico-estrutural das desigualdades socioespaciais entre as regiões do país e dentro das próprias cidades, sobretudo daquelas que mais se modernizavam, enriqueciam e viam crescer sua população - as metrópoles. As mudanças nos usos do território impactaram fortemente nas condições de vida, trabalho e saúde dos cidadãos. Iniciou-se um processo intenso de crescimento demográfico e de urbanização (com aumento das migrações internas), significando maior acesso ao emprego formal e, consequentemente, ao sistema de proteção social para a população. O crescente 
acesso aos serviços de saúde e as desigualdades socioespaciais geravam enorme pressão sobre os sistemas de saúde.

O debate sobre as desigualdades regionais das condições de saúde no Brasil e da necessidade de políticas públicas de saúde para resolver essa questão, se fortalece com a emergência do "sanitarismo desenvolvimentista" (1955-1964). Este movimento se originou no contexto das lutas pela democratização, durante o Estado Novo, e de emergência do nacional-desenvolvimentismo, concomitante à intensificação do processo de industrialização e urbanização do país (LABRA, 1988). Era um movimento de crítica ao sanitarismo campanhista, centralizador e autoritário que nasceu com a Reforma Carlos Chagas entre 1920-23, tendo seu auge entre 1938-45. Criticava a centralização das ações de saúde, o esvaziamento do papel dos estados nas divisões regionais e dos municípios no atendimento das prioridades locais, e a uniformização dos serviços sanitários seguindo tecnicamente o modelo norte-americano dos centros de saúde (LABRA, 1988).

A ideia-força do sanitarismo desenvolvimentista era a de que o nível de saúde da população depende do grau de desenvolvimento econômico regional e nacional "e que, portanto, as medidas de assistência médico-sanitária são, em boa medida, inócuas quando não acompanham ou integram esse processo" (LABRA, 1988, p.15). Destacam-se Samuel Pessoa e Josué de Casto como importantes intelectuais que pensaram a relação saúde e desenvolvimento a partir da identificação das desigualdades regionais no Brasil. Notadamente a obra de Josué de Castro, Geografia da Fome, questionou o significado de desenvolvimento a partir da questão da fome, problema tabu, regionalizando o país em áreas de fome endêmica, fome epidêmica e áreas de subnutrição (CASTRO, 1961).

Os problemas de saúde eram compreendidos como resultantes também das precárias condições de vida da população, consequências do subdesenvolvimento do país e das regiões, que gera empobrecimento e escassez de recursos locais. Essa era uma posição crítica importante, pois não via as condições precárias de saúde como atraso para o desenvolvimento, mas, sim, como resultantes, e não causa, do subdesenvolvimento, tratava-se de uma questão social (BRAGA \& PAULA, 1981; LIMA et al, 2005). 
Contudo, o Estado desenvolvimentista abarcava uma concepção particular de desenvolvimento social, "entendido como a incorporação dos até então excluídos do mercado formal de trabalho ao processo produtivo, como subproduto do crescimento e do desenvolvimento econômico" (CONH, 2005, p.386). Ao colocar a industrialização como sinônimo de desenvolvimento econômico e o desenvolvimento social como uma consequência desse processo, as políticas sociais acabam por ocupar um lugar secundário, ou seja, subordinadas aos imperativos da política econômica.

No âmbito do planejamento nacional do desenvolvimento, a política de saúde foi contemplada no Plano SALTE (das primeiras letras de saúde, alimentos, transporte e energia), de 1947, associada à questão alimentar e ao combate às doenças transmissíveis (ARAÚJO, 1975; PENA, 1977). O caráter industrializante do plano é visível dada priorização dos transportes e da energia como infraestruturas necessárias para as atividades econômicas, mas a contemplação da saúde e dos alimentos também tem fundamentos basicamente econômicos ${ }^{22}$ (PENA, 1977).

A questão rural volta a ser enfatizada no âmbito da política nacional de saúde. Em 1953, a criação do Ministério da Saúde retoma as ideias do movimento pelo saneamento rural das décadas de 1910 e 1920, sobre as precárias condições de saúde da população, características do subdesenvolvimento e da pobreza (HAMILTON E FONSECA, 2003). Na década de 1950, a atuação do SESP deixa de focar prioritariamente as frentes de expansão da economia, para voltar-se às regiões e comunidades carentes, notadamente o vale do Rio São Francisco, expandindo sua atuação no território (VARGA, 2007).

Significativamente, a partir de então, se verifica uma diminuição nos investimentos americanos no SESP, com um progressivo aumento dos investimentos brasileiros e a atuação do SESP experimentaria uma rápida expansão: em 1952, iniciava sua atuação no Rio Grande do Sul e, em 1953, com a instalação, em Belém, da Superintendência do Plano de Valorização da Amazônia, o SESP passou a atuar em Goiás, Mato Grosso e no Maranhão. (VARGA, 2007, p.34).

\footnotetext{
${ }^{22}$ O Plano evidencia uma clara divisão de tarefas entre Estado e Mercado na assistência à saúde. "Em geral: quando a força de trabalho é afetada no seu rendimento por questões de saúde, os custos do combate às moléstias são socializados e a política é conduzida pelo Estado e seus agentes. Quando são indivíduos isolados que se encontram doentes, o problema da saúde é deixado ao mercado e à iniciativa privada." (PENA, 1977, p.73)
} 
O Governo de Juscelino Kubistchek (1956-1961) não inclui a saúde no seu Plano de Metas (PENA, 1977). Ele retoma a perspectiva de descentralização da organização dos serviços de saúde para os estados, com a participação do SESP (MELLO et al, 2011) e incorpora os serviços de saúde na agenda desenvolvimentista, através de um plano específico de combate às endemias rurais - chamadas "doenças de massa" -, que contava com a cooperação norte-americana e era amparado pelo discurso técnico-científico, no campo da saúde, e pelo discurso político ideológico, no campo do desenvolvimento (MUNIZ, 2009).

Em 1956, o Ministério da Saúde criou o Departamento Nacional de Endemias Rurais (DNERu) para a realização dessas ações. A erradicação das doenças transmissíveis constituía-se uma ação coordenada em larga escala no território nacional; o mesmo não se podia dizer sobre a organização e os investimentos nos serviços assistenciais, muito mais localizados em alguns lugares e regiões (MUNIZ, 2009).

A discussão sobre a organização regional das redes assistenciais se manteve ativa durante essa fase, mas muito restrita à integração dos serviços locais (MELLO et al, 2011). Em São Paulo, Rodolfo Mascarenhas criticou o caráter burocrático da política nacional de saúde, que mascarava seu viés político, a desorganização e a falta de um modelo único, que proporcionasse a integração assistencial com aumento dos gastos na medicina curativa (hospitais), além da preventiva (MELLO, 2010).

Na década de 1960, foi introduzida a ideia de planejamento em saúde nos países da América Latina, por meio da Carta de Punta del Este (OEA, 1961), no âmbito da "Aliança para o Progresso", dentro da estrutura da "Operação PanAmericana”. Essa Carta explicita a proposta de modernização para a América Latina, que os Estados Unidos tinham interesse de empreender para evitar a expansão do socialismo na região ${ }^{23}$. Nessa Carta, a saúde é um dos fatores para se medir o "desenvolvimento relativo" dos países, definido a partir "do nível médio de renda real ou do produto bruto per capita, como também os índices de mortalidade infantil e analfabetismo, e o número de calorias diárias por habitante” (OEA, 1961, p.158).

${ }^{23}$ A Carta enfatiza os objetivos da Aliança para o Progresso - condições, termos e financiamento (incluindo as fontes como os EUA, o BID e outros países desenvolvidos) - esclarecendo que "esse auxílio se destinará tanto ao melhoramento social como ao desenvolvimento econômico (...)" (OEA, 1961, p.162). 
A saúde aparece como um dos objetivos da Aliança para o Progresso, no que diz respeito: ao aumento da esperança de vida ao nascer; à melhoria da saúde individual e coletiva com vistas ao melhor desempenho produtivo e de aprendizado da mão-de-obra; à extensão do saneamento básico; à melhoria do nível nutricional; ao aperfeiçoamento da formação de sanitaristas e outros profissionais da saúde; à melhoria dos serviços básicos de saúde; à intensificação da pesquisa científica e da utilização dos conhecimentos produzidos para a prevenção e cura de doenças. Nesse contexto, em 1965, surgiu o primeiro método de planejamento em saúde conhecido como "Cedes/OPS", por se tratar de uma publicação da Organização Panamericana de Saúde com base nas concepções de desenvolvimento formuladas pela Cepal. Este era caracterizado pela racionalidade estritamente econômica e normativa de redução de custos no sistema público, sendo denominado planejamento normativo.

Em 1963, a saúde volta a ter proeminência no Plano Trienal, formulado por Celso Furtado durante o Governo de João Goulart; e pela primeira vez entra como questão social $^{25}$ do desenvolvimento (ARAÚJO, 1975; PENA, 1977). Destaca-se a atuação dos sanitaristas desenvolvimentistas na defesa de uma política de desenvolvimento includente e articulada ao planejamento nacional da saúde (MACHADO et al, 2010).

O Ministério da Saúde, após dez anos de sua criação, apresentava uma estrutura arcaica que não condizia com a nova realidade dos problemas sanitários do país e nem com os novos conhecimentos técnicos e científicos no âmbito da saúde ${ }^{26}$

\footnotetext{
${ }^{24}$ Problemas Conceptuales y Metodológicos de la Programación de la Salud (OPS/OMS, 1965).

25 Até 1963, a "questão social" entrou de maneira categórica na ideologia desenvolvimentista (TEIXEIRA, 1988).

${ }^{26}$ Segundo o Ministro da Saúde Wilson Fadul, a formulação de uma política sanitária condizente com os interesses do país, preconizada pelas diferentes correntes dos técnicos da Saúde Pública, tem alguns princípios fundamentais: 1 - Prioridades para os programas que beneficiem o maior número de pessoas a custos mais reduzidos; 2 - Utilização apropriada dos modernos conhecimentos científicos, ao alcance dos países subdesenvolvidos, com o objetivo de acelerar o declínio de mortalidade geral; 3 - Integração dos programas de saúde no plano federal de desenvolvimento econômico, com o máximo de aproveitamento dos recursos disponíveis; 4 - Fomento ao estudo dos problemas peculiares ao nosso meio, com incentivo à pesquisa visando à correta solução; 5 - Estímulo à formação de pessoal técnico que atenda à efetiva demanda dos programas assistenciais; 6 - Fortalecimento da indústria farmacêutica estatal, objetivando o aumento da produção de agentes químicos-profilátixos necessários ao tratamento das grandes endemias que prevalecem entre as camadas mais pobres da população; 7 Intensificação do sistema de planejamento para todas as atividades, de maneira a assegurar maior rendimento do instrumental médico-assistencial existente. (BRASIL, 1963).
} 
(BRASIL, 1963). Havia uma crítica à adoção direta de modelos de organização assistenciais provenientes de outros países, apontando a necessidade de uma nova política de saúde com base no conhecimento da realidade econômico-social do Brasil, para enfrentar os graves problemas sanitários, que afetavam grande parte da população, como consequência do pauperismo, e a escassez de recursos locais.

Havia a preocupação em elaborar um plano nacional de saúde, com a participação dos estados e municípios, incluindo mudanças organizacionais no Ministério da Saúde e reformas no sistema de saúde, com maior descentralização do poder para as esferas subnacionais (III Conferência Nacional de Saúde, Brasil, 1963). As desigualdades regionais se expressavam tanto em relação aos indicadores econômicos e sociais, quanto em termos da estrutura assistencial ofertada pelos estados. Nesse sentido, havia uma proposta de fortalecer o papel normativo e coordenador do Ministério da Saúde e proporcionar a integração de serviços e aproveitamento racional dos recursos disponíveis em âmbito estadual e nacional.

As críticas ao modelo de desenvolvimento e ao modelo da saúde no Brasil não chegaram a criar um sistema de proteção social universal, as ideias emergentes ${ }^{27}$ foram abafadas e o processo das reformas interrompido com o início da ditadura militar em 1964

Em meados da década de 1960, consolida-se uma visão fragmentada do processo de desenvolvimento, no âmbito dos planos federais, com a separação entre desenvolvimento econômico e desenvolvimento social, e a política de saúde ${ }^{28}$ passam a integrar a estratégia de desenvolvimento social do governo. Essa separação se concretiza, no Governo Geisel, com a criação dos Conselhos de Desenvolvimento (VELLOSO, 2007). A saúde foi mantida como um dos setores do desenvolvimento social juntamente com a educação e o saneamento no Plano de Ação Econômica do Governo (PAEG), no Plano Estratégico de Desenvolvimento e no I Plano Nacional

\footnotetext{
${ }^{27}$ Dentre os principais desdobramentos do novo debate sobre a relação entre saúde e desenvolvimento (ou subdesenvolvimento), estão as mudanças na concepção da ação do Estado na saúde, que, segundo Teixeira (1988, p.15) “muito provavelmente, teriam repercutido de forma 'revolucionária' na prática concreta dos aparelhos de Estado, não fosse o fato de o golpe de 64 ter interrompido bruscamente o avanço do processo democrático nacional". Contudo, a existência de um setor privado lucrativo na assistência à saúde criava, de certa forma, um obstáculo importante para essa transformação no papel do Estado na saúde, antes mesmo do golpe de 1964 (LIMA et al, 2005, p.27).

${ }^{28}$ Araújo (1975) faz uma revisão sobre as teorias que discutiram a saúde como desenvolvimento social e sua relação com o desenvolvimento econômico.
} 
de Desenvolvimento (PND) (ARAÚJO, 1975; PENA, 1977). No II PND, a saúde foi reconhecida pela sua importância para o desenvolvimento tecnológico e incluída como estratégia do desenvolvimento social, no âmbito da política de valorização dos recursos humanos, abrangendo programas na área de saúde pública e de assistência médica (PENA, 1977).

A partir da Reforma do Estado, em 1967, as secretarias estaduais de saúde também passaram por mudanças. Em São Paulo, a "Reforma Leser" ${ }^{29}$ inaugura uma nova fase da organização regional e planejamento do sistema de saúde. O objetivo era garantir a provisão da atenção básica por meio de uma rede própria de serviços, hierarquizada em cinco níveis, abarcando a gerência de programas e atividades relacionadas à vigilância epidemiológica e sanitária. O distrito sanitário aparece como estrutura intermediária de coordenação para as regionais de saúde e a coordenação de atividades com os municípios era restrita a alguns convênios e cessão de terrenos para construção de unidades (IBAÑEZ et al, 2009). As desigualdades da distribuição dos serviços de saúde em relação às necessidades da população e as diferenças espaciais das taxas de mortalidade marcaram a discussão sobre a organização regional do sistema de saúde e a identificação de áreas mais ou menos desenvolvidas em regiões metropolitanas ${ }^{30}$ (YUNES, 1969a e 1969b). A "Reforma Leser" revaloriza os centros de saúde "como unidades polivalentes" (MELLO et al, 2011), mas também cria divisões regionais para descentralização das ações técnico-administrativas do estado, considerando a complexidade e hierarquização dos serviços de saúde (desde os centros de saúde até hospitais), visando a integração e a integralidade. Além disso, são valorizadas as ações de planejamento, supervisão, coordenação e capacitação a partir da criação de órgãos específicos para a execução dessas funções (VIANA, 1994). A organização regional do sistema ganha uma maior densidade técnica, científica e normativa.

A "Reforma Leser" influenciou outros estados, dentre eles, a Bahia, resultando em processos de descentralização executiva da política de saúde, "que encontrou instrumentalidade no sistema de administração regionalizada" (ARAÚJO, 1973). No caso baiano, o objetivo principal era integrar e coordenar os serviços de

\footnotetext{
${ }^{29}$ Gestão de Walter Leser na Secretaria Estadual de Saúde de São Paulo.

30 "Pelas principais causas de óbitos, São Paulo se coloca numa situação intermediária entre áreas subdesenvolvidas e desenvolvidas." (YUNES, 1969b, p.41).
} 
saúde, aproximando-os das necessidades da população e estendendo-os para o interior do estado, a partir da divisão do estado em 21 regiões administrativas. Em 1966, foram instalados Centros Executivos Regionais de Saúde no estado, cujas regiões foram definidas considerando-se "equipamento comercial e de serviços, relações da cidade com o mundo rural, atividade industrial e função de centros de comunicação" (ARAÚJO, 1973, p.08). Segundo o autor, os resultados foram a melhoria na prestação dos serviços e no processo de planejamento em saúde.

No âmbito nacional, a década de 1970 foi marcada pelo aprofundamento da visão privatista na saúde, pela unificação dos Institutos de Aposentadorias e Pensões (IAPs) e a pela criação de um sistema nacional de saúde, num contexto de centralização política, crescente complexidade do sistema urbano e integração do mercado interno. A institucionalização do Sistema Nacional de Saúde, pela Lei $n^{\circ}$. 6.229, de 17/07/1975, consolida o modelo centralizado privatista (VIANA, 1994). A regionalização aparece como uma das estratégias desse sistema, através da criação das Coordenadorias Regionais de Saúde, que objetivava facilitar a descentralização e o estreitamento dos laços entre Planejamento do Desenvolvimento Sócio-Econômico Regional e os Planos de Saúde.

A organização regional do sistema foi conduzida pela lógica mercantilista (ELIAS, 2001), nas discussões sobre políticas sociais não estava contemplada uma concepção abrangente e ampliada de direitos sociais, implicando restrições e limitações para a expansão de tais políticas. Machado (2007:56) afirma que:

\footnotetext{
Houve certa dinâmica na expansão de algumas políticas sociais, incluindo as de saúde mesmo no período de autoritarismo militar após 1964. Isso ocorreu sob um modelo distorcido que, na área da saúde, teria propiciado um crescimento do segmento privado prestador de serviços ao Estado, um fortalecimento de mercados de saúde e ampliado a escala das operadoras econômicas na saúde, tanto no âmbito do segmento de assistência médica previdenciária, como no bojo do surgimento de um novo tipo de empresariamento na saúde.
}

Em contraposição ao modelo centralizado privatista, ganhou força $o$ movimento pela Reforma Sanitária, que objetivava tornar a saúde um direito social e unificar os serviços públicos em um sistema integrado, descentralizado e regionalizado, voltado para a saúde comunitária e a participação social. O movimento da Reforma Sanitária foi embasado por uma série de acontecimentos 
históricos e debates teóricos em torno da relação entre saúde e desenvolvimento no Brasil. A exemplo de sistemas universais de saúde de países europeus, esse movimento pretendia instituir o direito universal à saúde, garantido sob a responsabilidade do Estado. As principais ideias, gestadas desde antes do golpe de 1964 até o final da década de 1980, quando a Reforma ganhou força, foram amparadas pelo contexto da redemocratização do país e da descentralização. Também contribuiriam para legitimar a Reforma os custos crescentes e os desafios do financiamento do sistema de saúde, além dos problemas de saúde e acesso à assistência agravados pelo aumento das desigualdades urbanas e regionais. O movimento da Reforma foi ainda amparado pela declaração da Conferência Mundial de Saúde, realizada em Alma-Ata (1978): a "saúde é um direito humano fundamental, e que a consecução do mais alto nível possível de saúde é a mais importante meta social mundial, cuja realização requer a ação de muitos outros setores sociais e econômicos, além do setor saúde".

A organização regional do sistema, seja em distritos sanitários ou a partir de redes integradas estaduais, era uma das estratégias para a reorganização do sistema de saúde, aplicada inicialmente em algumas experiências estaduais e municipais, prévias à reforma sanitária, nas décadas de 1970 e 1980. Dentre essas experiências, destaca-se o Projeto Montes Claros, que foi implementado, em 1975, no norte do estado de Minas Gerais, uma região muito empobrecida, com o objetivo de estabelecer um novo modelo de organização e integração regional do sistema de saúde, baseado nos princípios da descentralização, da democracia e da participação popular (TEIXEIRA, 1995).

A proposta de regionalização do Projeto Montes Claros focava a organização técnico-normativa da rede de saúde, com serviços integrados e hierarquizados quanto à complexidade e abrangência espacial, mas focava, sobretudo, a perspectiva de descentralização do planejamento em saúde, envolvendo a participação de uma diversidade de agentes do Estado e da sociedade (TOBAR, 1995). A regionalização era tanto técnica-administrativa quanto política, visando o enfrentamento do autoritarismo e as disputas do poder local ${ }^{31}$ (TEIXEIRA, 1995).

\footnotetext{
31 "Esta modernização autoritária introduzia a problemática da descentralização como uma tensão permanente entre o planejamento centralizado e a administração regionalizada. Por um lado, ao
} 
Por um lado, o projeto estava sob a influência das ideias difundidas pela Organização Pan-americana de Saúde (OPAS) na América Latina, especificamente as noções de sistema integrado de prestação de serviços de saúde, distritos sanitários e medicina simplificada e comunitária, além de recuperar propostas de organização regional do SESP, anteriores a 1964 (TEIXEIRA, 1995). Os termos zona urbana, zona rural, áreas, atenção primária em saúde, comunidade e participação comunitária marcaram as estratégias de extensão de cobertura e organização regional dos serviços e sistemas de saúde na América Latina, na década de 1970. A Organização Panamericana de Saúde propunha a extensão da cobertura em áreas rurais e periferias urbanas com a difusão de serviços de saúde menos especializados e custosos (atenção primária em saúde - modelo norte-americano) (TENTORI, 1977). A "regionalização" da política de extensão da cobertura dos serviços de saúde era definida, primeiramente, com base nas demandas de uma "população determinada" ou comunidade.

Por outro lado, o Projeto aproveitou-se também das críticas que estavam sendo formuladas contra o método do planejamento normativo (difundido pela OPAS para a América Latina no contexto da centralização e autoritarismo político) (TOBAR, 1995). Em contraposição ao planejamento normativo, o planejamento estratégico, proposto por Carlos Matus, incorporava o conceito de poder em saúde a partir de categorias de natureza político-social, do comportamento histórico, do princípio do desequilíbrio, considerando os aspectos quantitativos e qualitativos em saúde (RIVERA, 1982; 1987). O planejamento estratégico da saúde vigorou na América Latina até a década de 1980 (CHORNY, 1998), provocando avanços com a ampliação da discussão de poder em saúde para além dos entes governamentais, iniciando o debate sobre a participação popular no planejamento - debate que foi sufocado durante o período das ditaduras militares na região (GIOVANELLA, 1991).

deslocar a execução das políticas para as regiões, abria-se o espaço para a atualização das disputas pelo poder local, ampliando, através da política pública, as possibilidades de introdução de novos atores que desequilibravam a competição oligárquica. Neste sentido, tanto a burocracia técnica, envolvida na implantação dos projetos regionais quanto a comunidade, entendida como rede de usuários e servidores de extração local nucleados pelos serviços de saúde, introduziram uma cunha redefinindo os contornos da estrutura de poder local”. (TEIXEIRA, 1995, p.252). 
A reformulação do sistema nacional de saúde a partir de estratégias regionais e descentralizadas se difundiu no Brasil, entre 1979 e 1982, com o Programa de Interiorização de Ações de Saúde e Saneamento (PIASS) e o Prev-saúde. Estes programas já apresentavam um modelo de gestão bastante distinto do privatistacentralizado, dando prioridade ao setor público e à assistência primária, buscando novas formas de integração entre as esferas estaduais e municipais de governo (VIANA, 1994, p.36). Nos estados, a estratégia de regionalizar a saúde para estruturar um novo modelo de sistema de saúde, serviu para organizar redes regionalizadas e distritos sanitários, mas seu foco principal foi induzir o processo de descentralização. Esse processo, e seus reflexos no sistema de saúde, tem início no final da década de 1970, caracterizado pelo movimento municipalista, quando prefeitos aliados aos governos estaduais iniciaram um processo de descentralização partindo das esferas subnacionais (VIANA, 1998).

$\mathrm{Na}$ política de saúde, a descentralização ganhou força com as Ações Integradas de Saúde (AIS) (1983-86), amparada por conceitos e mecanismos específicos de financiamento, coordenação e articulação intergovernamental (Lima, 1999). Posteriormente, foi criado o Sistema Unificado e Descentralizado de Saúde (SUDS) (1987-89).

A ideia de organizar regionalmente o sistema de saúde, a partir de arranjos técnico-administrativos, com o objetivo de garantir maior organicidade e racionalidade para o sistema, esteve presente nas comissões interinstitucionais de âmbito regional (Cris) do Programa das Ações Integradas de Saúde (AIS) e nos distritos sanitários municipais no SUDS (NASCIMENTO, 2007).

Nas Ações Integradas de Saúde a estratégia de regionalizar a assistência se manteve centrada na atenção primária e nos centros de saúde, que definiam distritos sanitários, integrando serviços através de redes regionalizadas. Entretanto, a ideia de regionalização passou a abarcar também a complexidade dos outros níveis e especialidades de serviços que compunham a redes assistenciais (hospitais, por exemplo) e a diversidade das esferas administrativas responsáveis pela gestão, planejamento e financiamento dos serviços de saúde. Surge a necessidade de coordenação intergovernamental e espaços para este fim, a exemplo das Comissões Regionais Interinstitucionais de Saúde/AIS, responsáveis por integrar e coordenar as 
ações de saúde ${ }^{32}$ de diferentes esferas administrativas, numa dada região (TANAKA, 1992). As AIS foram uma importante experiência na unificação dos serviços de saúde, um aprendizado para o convívio entre instituições, que "a despeito dos seus objetivos comuns, nada tinham a ver umas com as outras, na gerência de serviços a seu cargo" (BRASIL, 1986).

Desde 1982, quando foi elaborado o Plano do CONASP, e, especialmente, após o estabelecimento da política de Ações Integradas de Saúde (AIS), em 1984, verifica-se uma importante expansão da rede de serviços primários de saúde - basicamente, a rede pública de centros de saúde das prefeituras e dos Estados. O INAMPS teve um papel fundamental no financiamento da expansão dessa rede, comprando seus serviços através dos convênios das AIS. Com isso, em 1986, atingiu 2.418 prefeituras de todos os Estados da Federação. Mais do que mero repasse de recursos do nível federal para os demais níveis de governo, a compra de serviços da rede pública atuou como um poderoso incentivo para que as prefeituras e as secretarias estaduais de saúde passassem a investir em assistência médica e, o que é mais importante do ponto de vista da racionalização do sistema, a dirigir seus investimentos para a atenção ambulatorial. (VIANA, 1994, p.40).

No final da década de 1980, a luta pela redemocratização do país e a mobilização de vários segmentos da sociedade pela ampliação dos direitos sociais fortaleceu a agenda do movimento sanitarista brasileiro. A proposta de universalização da saúde através da criação do Sistema Único de Saúde foi debatida durante a $8^{\text {a }}$ Conferência Nacional de Saúde ( $8^{\text {a }}$ CNS), em 1986.

O lema do Ministro de Estado da Saúde Roberto Figueira Santos, durante a abertura da $8^{\text {a }}$ CNS era “regionalizar já!” (BRASIL, 1986). Tratava-se, contudo, de “descentralizar já!”, pois o desafio era coordenar a descentralização do poder para os entes federativos, "como remédio para a abusiva e sempre crescente concentração de poder político, econômico e administrativo exercida àqueles tempos [regime militar] pelo governo federal" (BRASIL, 1986). A reforma tributária, que estaria entre as matérias da Assembleia Constituinte, deveria assegurar aos estados e municípios maiores poderes de decisão sobre aplicação de recursos da saúde, em percentual da receita superior ao que era destinado até aquele momento. O município tornou-se

\footnotetext{
${ }^{32}$ Em cada região de saúde, nos Estados, criou-se uma Comissão Regional Interinstitucional de Saúde (CRIS), com a atribuição de realizar o planejamento integrado e a coordenação das AIS, contando com a participação de representantes regionais da secretaria estadual e do Inamps, assim como de representantes das diferentes organizações. (VIANA, 1994, p.39).
} 
peça-chave do novo processo de descentralização, como fica evidente nas palavras do ministro: “o município, a verdadeira 'célula' política da nação” (BRASIL, 1986).

A descentralização também estava associada à redemocratização e deveria proporcionar uma participação mais direta dos usuários dos serviços, no planejamento, no controle de qualidade, na gestão e na fiscalização das atividades, fortalecendo o processo de participação social.

O contexto da luta pela descentralização e municipalização no Brasil contribuiu para reforçar algumas estratégias de planejamento da rede assistencial definidas pela Organização Pan-americana de Saúde (OPAS) para a América Latina. Destaca-se o exemplo dos Sistemas Locais de Saúde (SILOS) - modelo de "territorialização" e descentralização da saúde para a estruturação de sistemas locais, que associava distritos sanitários e atenção primária, a partir de uma perspectiva das diferentes situações sociais e de saúde (PAGANINI, 1989; MENDES, 1993). Mas os documentos produzidos pela Organização Pan-americana de Saúde não entraram no mérito das causas das desigualdades e disputas de poder na saúde (GIOVANELLA, 1991).

A partir de 1987, com o Sistema Unificado e Descentralizado de Saúde (SUDS), a descentralização começou a fazer a divisão de tarefas entre os entes (municípios responsáveis pela atenção primária e estados pela média e alta complexidade) e o mecanismo de integração do sistema passou a ser a transferência de serviços federais (Inamps) para estados e municípios. Através do SUDS, a transferência da gerência do Inamps para as Secretarias Estaduais de Saúde criou um novo mecanismo de integração dos serviços, ao invés da cooperação interinstitucional, "a unificação mediante a estadualização e a municipalização dos serviços" (VIANA, 1994, p.41).

Quando o Sistema Único de Saúde (SUS) começou a ser estruturado no território brasileiro, na década de 1990, a estratégia da descentralização políticoadministrativa foi privilegiada para garantir sua estruturação a partir dos estados e, sobretudo, dos municípios.

Por um lado, isso condiz com o próprio momento de constituição do SUS, quando a descentralização de recursos, competências e responsabilidades para as esferas subnacionais foi identificada, no discurso contra o regime militar e o 
autoritarismo, com a ampliação da democracia e maior eficiência governamental (ALMEIDA, 2007). Além disso, o ideário da descentralização tinha o significado de unificar o discurso de diferentes atores políticos interessados em ampliar sua participação nas arenas decisórias, principalmente governamentais, e no bolo tributário. Por outro lado, a prioridade dada à descentralização atendia também aos ideais de redução do papel do Estado e dos gastos públicos previstos na reforma do Estado de inspiração neoliberal (VIANA \& MACHADO, 2009).

Durante os dez primeiros anos de implantação do SUS (1990-2000), a estratégia da descentralização das ações e serviços, sobretudo, para o nível municipal, não esteve associada a uma proposta de regionalização, tensionando a lógica sistêmica e solidária do SUS (VIANA, 1994; YUNES, 1999). Ao mesmo tempo em que se definiam as competências e responsabilidades dos três níveis de governo no âmbito do sistema nacional de saúde, era preciso também se atentar para as formas de relacionamento entre as esferas para garantir a integração e a articulação dos serviços no território, a partir da estratégia de regionalização das redes assistenciais, o que não ocorreu no início da construção do SUS (VIANA, 1994).

No contexto neoliberal, o fraco papel desempenhado pelo Estado brasileiro na formulação de uma agenda de desenvolvimento e do planejamento de médio e longo prazo desfavoreceu a adoção de estratégias de regionalização para a execução das políticas públicas (PIQUET \& RIBEIRO, 2008). Além disso, houve um empobrecimento dos debates político e acadêmico sobre as questões sociais no país e sobre as formas de enfrentá-las, a partir de tendências empiricista e reducionista da política social, com focalização na pobreza (VIANNA, 2011).

A crise política (papel do Estado Regulador) e econômica que se instalou no Brasil afetou diretamente as possibilidades de elaboração e execução de políticas federais de fôlego, condizentes com a dimensão e a complexidade do projeto de universalização da saúde, inclusive no que se refere ao fortalecimento da lógica sistêmica e regional de organização do SUS (VIANA, 1994).

Um processo crescente de centralização financeira do Estado ao lado do exercício continuado de regulação fiscal sobre os entes federativos e um papel decisivo na formulação de políticas produziu uma combinação de centralização 
estatal federal com políticas setoriais descentralizadoras, que no caso da saúde estiveram sempre na dependência da indução federal (VIANA et al., 2008). Cabe lembrar que a capacidade normativa do governo federal se afirmou sobre as esferas subnacionais no processo de ajuste fiscal e renegociação das dívidas dos Estados e mais fortemente quando da instituição da Lei de Responsabilidade Fiscal, o que produziu um enfraquecimento da esfera estadual, com repercussões sobre a capacidade dos estados em formularem políticas públicas de natureza mais autônoma e de recorte supramunicipal.

Nessa fase, a política nacional de saúde não incorporou a dimensão territorial a partir de seus diferentes usos e como estes também condicionavam a conformação do SUS nos estados, dificultando a elaboração de políticas públicas e a definição de investimentos que relacionassem as necessidades de saúde às dinâmicas territoriais diversas, com vistas à diminuição das desigualdades regionais (VIANA et al., 2007). Soma-se a isso a dificuldade de estabelecimento de uma relação intergovernamental mais cooperativa e menos centrada no binômio União-município e a dificuldade de elaboração de uma visão integrada da dinâmica territorial brasileira, em rápida transformação, por conta da fragmentação das políticas extremamente setoriais (VIANA et al, 2008).

A lógica da descentralização, resultando na fragmentação das ações e serviços no território, teve mesmo um sentido contrário à lógica sistêmica que demandava o novo modelo assistencial de saúde no país (VIANA, 1994; CAMPOS, 2006).

No início dos anos 2000, os diagnósticos sobre as limitações da descentralização para estruturar o SUS e lidar com o aumento das desigualdades socioespaciais em saúde confirmaram a necessidade de combinar a descentralização com estratégias regionais. Disso resultou a publicação da primeira diretriz nacional de regionalização do SUS: a Norma Operacional de Assistência à Saúde - Noas $(2001 / 02)$.

A partir de 2006, a estratégia da regionalização se fortaleceu no contexto da proposição de uma nova agenda de desenvolvimento, que visava à redução das desigualdades sociais e regionais em saúde, o fortalecimento da gestão, da 
cooperação intergovernamental e do planejamento do SUS e a ampliação dos investimentos no sistema.

A política nacional de saúde entrou na nova agenda de desenvolvimento brasileiro em duas frentes: (i) como política social, visando a ampliação dos investimentos públicos na rede assistencial e organização da rede através da descentralização, da regionalização, da integração dos serviços, da articulação intergovernamental e da gestão pública e privada, com foco na diminuição das desigualdades em saúde e da fragmentação do sistema; (ii) dialogando com a política de ciência, tecnologia e inovação, visando a institucionalização da Política Nacional de Ciência, Tecnologia e Inovação em Saúde, com ampliação de parcerias entre governo federal e estados para ampliar os investimentos em pesquisas para o SUS; e o uso do poder de compra do Estado, através das aquisições do SUS, para alavancar a produção nacional de medicamentos e equipamentos médico-hospitalares, com investimentos públicos e privados em inovação e P\&D em saúde, e foco na inovação e fortalecimento do parque industrial brasileiro e na diminuição da dependência externa do SUS em relação aos produtos e equipamentos de saúde (déficit na balança).

Na primeira frente, como política social, o Pacto pela Saúde ${ }^{33}$ (2006) elegeu a regionalização do SUS como estratégia prioritária para a integração dos serviços e ações de saúde e a diminuição das desigualdades socioespaciais em saúde. Foram criados os Colegiados de Gestão Regional (CGRs) como espaços para as negociações intergovernamentais (estado e municípios), para organizar as redes assistenciais regionalizadas e orientar a ampliação dos investimentos públicos no SUS.

Em 2011, o Decreto Presidencial no 7.508 deu novas diretrizes à regionalização do SUS incorporando um conceito mais estruturado de redes de atenção à saúde (Portaria 4.279/10), novos instrumentos de planejamento regional, como o Contrato Organizativo da Ação Pública em Saúde (Coap) e o Mapa da Saúde, e definindo o rol mínimo de ações, procedimentos e tecnologias oferecidos pelo SUS.

\footnotetext{
${ }^{33}$ A Portaria $n^{\circ}$. 399/GM de 22 de fevereiro de 2006 divulgou o Pacto pela Saúde 2006 e aprovou as Diretrizes Operacionais do Referido Pacto, com três componentes principais: o Pacto pela Vida, o Pacto em Defesa do SUS e o Pacto de Gestão do Sistema Único de Saúde (SUS).
} 
A trajetória da política de saúde no Brasil e os desafios postos para a universalização da saúde no território indicam a importância crescente da estratégia de regionalização para o planejamento e a gestão do SUS. Ao mesmo tempo, as mudanças nas diretrizes nacionais evidenciam o aumento da complexidade técnica, normativa e política dessa estratégia.

A partir dessas considerações, questiona-se: em que sentido as diretrizes nacionais de regionalização progrediram em relação aos seus objetivos, instrumentos, normas e definições? É possível verificar mudanças induzidas pelas diretrizes nacionais no processo de regionalização do SUS nos estados, a partir da segunda metade da década de 2000? Em que sentido progrediu a regionalização nos estados e como compreender os condicionantes e as especificidades desse processo?

O presente trabalho tem por objetivo analisar o enfoque regional na política de saúde brasileira, entre 2001 e 2011, considerando as mudanças nas diretrizes nacionais de regionalização do Sistema Único de Saúde e o processo de regionalização nos estados.

Parte-se da hipótese de que, em dez anos (2001-2011), o enfoque regional progrediu no sentido de tornar a região de saúde o recorte privilegiado para lidar com a dimensão territorial da universalização da saúde e induzir mudanças na política, no planejamento, financiamento, na gestão e organização técnica do Sistema Único de Saúde (SUS), a fim de assegurar uma ação mais eficaz do Estado na garantia do direito à saúde. A partir de 2010, a forte associação entre as diretrizes de regionalização e das redes de atenção à saúde tendeu a priorizar o enfoque das redes nos estados, tornando mais complexa a ideia de regionalização. Mas a capacidade de induzir mudanças e garantir a universalização a partir das redes e regiões de saúde vai depender das características e dos condicionantes da conformação do sistema e das políticas de saúde nos estados e municípios. As diversidades e desigualdades socioespaciais associadas à forma de organização política do território brasileiro criam limitações e especificidades para o planejamento e gestão regional do SUS.

Neste trabalho, utilizou-se o referencial teórico da geografia humana (geografia nova) e da análise de políticas públicas (institucionalismo histórico), pesquisa bibliográfica sobre o tema, análise de dados secundários, análise 
documental e entrevistas com atores-chave do processo de regionalização nos estados.

Foram elaborados quatro capítulos e as conclusões.

O Capítulo 1. Região e regionalização: atualidade dos conceitos e planejamento regional no Brasil traz um resgate teórico sobre o conceito de região que tiveram maior repercussão na ciência e no planejamento brasileiro; considerando as contribuições da Geografia (trata-se de uma categoria de análise desta disciplina), mas, também, as contribuições da Economia, dada sua grande influência sobre as teorias e práticas do planejamento regional no Brasil e no Mundo. Em seguida, é abordada a relação intrínseca entre regiões e redes geográficas. Por fim, o capítulo traz um breve resgate histórico sobre práticas de regionalização e de planejamento regional do território brasileiro, indicando as principais influências teóricas, os objetivos e a relação das diferentes estratégias de planejamento regional adotadas com o papel assumido pelo Estado na condução do desenvolvimento nacional, entre 1930 e 2011.

A região geográfica é uma categoria de análise científica, que pressupõe um olhar sobre a totalidade do mundo e a análise da dinâmica dos lugares em relação à dinâmica mundial. É um recorte espacial baseado na relação entre os lugares regida pela divisão internacional do trabalho. A região geográfica expressa a diversidade de formas de incorporação das inovações que vem de fora e as conexões geográficas que dinamizam e especializam a produção, a circulação e o consumo numa determinada contiguidade espacial.

Já a região de saúde não é uma região geográfica ou uma região do ponto de vista metodológico, trata-se de uma estratégia de planejamento setorial para a organização política-institucional e técnica-assistencial, com vistas a tornar mais eficaz a ação do Estado de garantir o direito à saúde. As regiões de saúde são constituídas com o propósito principal de regular e organizar as redes assistenciais hierarquizadas (conforme a tipologia dos serviços e sua concentração em polos regionais), para ampliação do acesso à saúde condizente com as necessidades da população e com as possibilidades e responsabilidades técnicas, políticas e financeiras de provisão das ações e serviços por cada ente federado. 
Ainda que a região geográfica não seja sinônima de região de saúde, ou de qualquer outra regionalização decorrente das práticas de planejamento, acredita-se que seu conceito bem definido ajuda a elucidar quais são os motores da divisão territorial do trabalho e das diferenciações espaciais, que interessam diretamente para a elaboração das regionalizações. A discussão específica sobre o conceito de redes geográficas segue esse mesmo propósito e deve auxiliar na compreensão sobre a importância das definições de redes de saúde.

Já o resgate das políticas nacionais de desenvolvimento regional visa identificar a coerência entre as propostas de regionalização do território e as diferentes agendas do desenvolvimento brasileiro, considerando os conceitos de região utilizados, os objetivos do planejamento e o papel exercido pelo Estado a cada momento. Esse panorama deve servir como contexto geral para a análise sobre a evolução das propostas de regionalização do Sistema Único de Saúde.

O Capítulo 2. O enfoque regional nas diretrizes nacionais de planejamento e gestão do Sistema Único de Saúde (2001 - 2011) descreve as principais contribuições e limitações de cada uma das diretrizes nacionais para a regionalização do SUS, contextualizadas pelas mudanças gerais na política nacional de saúde. O capítulo aborda as diferenças entre as definições de região de saúde, os objetivos da regionalização, seus critérios, instrumentos e responsáveis, caracterizando três fases: a "regionalização normativa" (2001), a "regionalização viva" (2006) e a "regionalização contratualizada" (2011).

O Capítulo 3. Redes de atenção à saúde e redes interfederativas como bases técnicas e políticas da regionalização do Sistema Único de Saúde faz um breve resgate sobre as diferentes noções de rede de saúde que influenciaram a política brasileira, considerando as experiências e documentos nacionais e internacionais que serviram como referência para o país. Destacam-se os conceitos de redes de atenção à saúde e redes interfederativas de saúde. Em seguida, o capítulo traz uma análise sobre a inserção dos conceitos de redes de saúde nas diretrizes de regionalização do SUS e elenca os principais eventos relacionados à institucionalização das redes de saúde na política nacional (1990 - 2002), considerando normas, programas, projetos, documentos e mudanças no organograma ministerial. Discute-se a forte associação entre as diretrizes de regionalização e das 
redes de atenção à saúde e como estas tornam mais complexa a estratégia de regionalização.

O Capítulo 4. Experiência recente de regionalização do Sistema Único de Saúde nos estados brasileiros (2007-2010) analisa os dados empíricos ${ }^{34}$ referentes à experiência recente de regionalização nos estados (2007-2010), considerando os diferentes estágios desse processo, segundo os contextos (histórico-estrutural, político-institucional e conjuntural), a direcionalidade (ideologia, objeto, atores, estratégias e instrumentos) e as características da regionalização (institucionalidade e governança). Agregaram-se os estados em quatro grandes regiões brasileiras Região Concentrada, Amazônia, Nordeste e Centro-Oeste, definidas por Santos \& Silveira (2001), com base nas diferentes situações geográficas que marcam o território brasileiro no período da globalização. A partir daí, analisou-se de que maneira as situações geográficas que caracterizam os "quatro Brasis" também condicionam a existência de contextos e características mais ou menos favoráveis para a institucionalidade e a governança da regionalização do SUS nos estados. O capítulo traz uma breve consideração sobre os aprendizados e desafios apontados com base nas experiências analisadas.

Por fim, as conclusões sintetizam as análises elaboradas com base no objetivo proposto e apontam alguns desafios para a atual fase da regionalização do SUS.

34 Os dados empíricos utilizados neste capítulo foram extraídos da pesquisa Avaliação das CIBS Nacionais: as CIBs e os Modelos de Indução da Regionalização do SUS, coordenada pela Dra. Ana Luiza D'Avila Viana (FMUSP), onde tive a oportunidade de participar como pesquisadora. Os resultados dessa pesquisa foram amplamente publicados em Viana \& Lima (2011). 


\section{Capítulo 1. Região e regionalização: atualidade dos conceitos e planejamento regional no Brasil}

A etimologia da palavra região vem do latim e tem dois significados: 1 . regio,ónis "direção, linha reta; caminho direito, freqüentado", 2. de regère "dirigir, guiar, conduzir, reger, governar" (Dicionário Houaiss). O significado de reger, governar, explica-se por ser a região referência para a unidade político-territorial em que se dividia o Império Romano; carrega uma conotação eminentemente política em sua concepção original (CORRÊA, 1997).

A região é uma categoria de análise da Geografia, por vezes, conceituada também por outras ciências, tais como a Economia. A regionalização é uma prática de delimitação das diferenciações espaciais no território e implica elaboração de um planejamento regional, que é uma técnica de aplicação de políticas públicas incluindo seu vínculo com o território (PIQUET \& RIBEIRO, 2008). A Geografia e, sobretudo, a Economia são as duas áreas com maior influência sobre o planejamento regional e as propostas de regionalização.

No Brasil, a regionalização configura-se como uma estratégia de delimitação de áreas para fins de planejamento do desenvolvimento e administração dos serviços públicos (Constituição Federal, 1988).

A regionalização procura responder a uma série de questões relacionadas ao planejamento, à descentralização política e administrativa, à coordenação política, à solidariedade, articulação, segurança jurídica e equilíbrio nas relações entre os entes federados, à resolução de problemas em diferentes escalas e níveis de complexidade, à integração territorial, à organização de grandes sistemas técnicos e à conjugação de esforços no combate às desigualdades socioespaciais.

\subsection{Atualidade do conceito de região}

A região é um fenômeno essencialmente geográfico - ela existe porque nenhum lugar é igual ao outro no mundo, é consequência da diferenciação espacial. 
O que interessa nos estudos regionais é compreender como esta diferenciação se processa, quais são seus motores e as variáveis-chave que definem as formas e os conteúdos regionais, em cada momento histórico.

No final do século XIX, quando a Geografia se firma como disciplina acadêmica, o tema da região se torna clássico na história do pensamento geográfico, marcando as disputas entre seus paradigmas fundadores (CORRÊA, 2007). Por um lado, alguns geógrafos reivindicavam o imperativo dos aspectos físicos (clima, relevo, hidrografia e vegetação) sobre os aspectos humanos (técnica, economia e cultura) na produção das paisagens regionais. Definiam, assim, as regiões geográficas como "naturais", identificadas pelos aspectos físicos das paisagens. Por outro lado, no contexto das disputas europeias sobre as vias do desenvolvimento capitalista, o geógrafo francês Vidal de La Blache questionou o peso dos aspectos físicos na explicação da evolução das sociedades, demonstrando, por exemplo, que a "região natural" não se constituía mais como um referencial ${ }^{35}$ para explicar as diferenças do processo de desenvolvimento econômico e social que se processam no espaço geográfico; fundando, assim, a Geografia Humana (CORRÊA, 1997).

A ideia de progresso técnico e social, que marcou a Europa no século XIX, influenciou fortemente o pensamento de Vidal de La Blache, sobretudo, quanto ao conceito de gênero de vida. Este, compreendido como um conjunto de técnicas e costumes culturais, que diferenciavam os lugares e paisagens no mundo, seria a fonte do progresso humano e da civilização (LA BLACHE, 1956, MORAES, 1999). La Blache defendeu a história e a criatividade humana na produção da técnica e da cultura (gênero de vida) como sendo os imperativos no processo das diferenciações espaciais e da delimitação das regiões (MORAES, 1999).

Na primeira metade do século XX, o crescimento da produção industrial, a expansão das redes de transporte e comunicação e o fenômeno da urbanização, tornaram-se elementos centrais na estruturação das regiões. As metrópoles, principais expressões espaciais da civilização e do desenvolvimento, abrigavam diversos serviços e equipamentos urbanos e se conectavam com outros lugares através de

35 Espanta que nos dias de hoje as bacias hidrográficas ainda sejam utilizadas como referência de planejamento regional no Brasil. As bacias hidrográficas não têm qualquer "poder criador em relação ao fenômeno regional (...). Não têm notável importância no plano das relações humanas e das trocas." (LABASSE, 1960, p.19). Segundo o autor, isso representa uma volta à Geografia Física para fundamentar a divisão regional, já há muito superada. 
redes de transporte, como as ferrovias, caracterizando-se como verdadeiros centros regionais (LA BLACHE, 1943).

Os estudos regionais inspirados em La Blache foram desmembrados em especialidades, originando diversas "geografias" (urbana, agrária, econômica, da população, da indústria, etc.). A Geografia Econômica ganhou importância nas análises regionais, englobando os vários elementos que ajudavam a explicar a situação econômica de uma região; e aproximando-se da Economia, nos Estados Unidos, influenciou a criação da Regional Science (MORAES, 1999; FUJITA \& KRUGMAN, 2004).

Cresce a necessidade de se entender as diferenciações espaciais do ponto de vista econômico, como um resultado da divisão internacional do trabalho, principal motor da acumulação de capital. Do final do século XIX até a primeira metade do século XX, as teorias econômicas avançaram tentando explicar como se processava o padrão de localização industrial e das atividades agrícolas, a partir da elaboração de esquemas regionais. Von Thünen (final do século XIX) foi pioneiro nesse campo, seguido de Lösch (década de 1940) e Walter Isard, que fundou a Regional Science, nos Estados Unidos, na década de 1950 (JUILLARD, 1965). Destaca-se também os trabalhos de Christaller (1933).

Nessa perspectiva, a região era definida a partir de uma racionalidade estritamente econômica ${ }^{36}$ e segundo uma visão de espaço homogêneo, desconsiderando-se outros elementos que criavam as diferenciações espaciais. A regionalização do território era pensada a partir das forças de concentração e dispersão dos fatores de produção (renda da terra, custo dos transportes e matériasprimas), do mercado consumidor e das atividades urbanas, que resultavam na diferenciação espacial do crescimento (economias de aglomeração) (ISARD, 1956; DINIZ, 2001).

No contexto da crise de 1929, o Estado apresenta-se como agente privilegiado na condução de projetos de desenvolvimento "que resultariam não apenas na expansão do produto e do emprego, mas também, na superação das desigualdades espaciais" (PIQUET \& RIBEIRO, 2008, p.50). Em 1933, no contexto do New Deal

\footnotetext{
${ }^{36}$ A racionalidade puramente econômica, voltada para a localização industrial e regionalização dos mercados e investimentos, ainda é a base dos trabalhos desenvolvidos pela Regional Science nos Estados Unidos (FUJITA \& KRUGMAN, 2004).
} 
americano, surge o regional planning a partir de duas experiências de investimentos federais em projetos de potencial hidrelétrico (o Tennessee Valley Authority e o Columbia River Basin Project), com o objetivo geral de elevar os padrões de vida em regiões especializadas na produção agrícola e empobrecidas com a crise (FRIEDMANN \& BLOCH, 1990).

A grande depressão de 1929, também estimulou o desenvolvimento de teorias para explicar as relações espaciais do processo de organização e especialização econômica e a hierarquização dos centros urbanos. A teoria dos lugares centrais de Christaller (1933) revelou-se um modelo facilmente operacional para o planejamento regional do desenvolvimento. Partindo de variáveis como densidade populacional, rede de transportes, mercado consumidor, distribuição dos serviços e da renda, Christaller observou o princípio da centralidade dos núcleos urbanos, concentradores de serviços, população e renda, em torno dos quais passava a existir uma região complementar, que dependia do núcleo central para acessar bens e serviços urbanos especializados. A hierarquia dos núcleos centrais seria dada pela oferta de bens e serviços mais ou menos especializados e sua área de abrangência regional.

Até 1950, o planejamento regional estava atrelado à expansão da urbanização, da industrialização e das atividades agrícolas e à extensão das vias de transporte. Destacam-se as teorias geográficas europeias e americanas que propunham critérios para a definição com base em seus processos e estruturas. Dentre eles: a existência de um centro (cidade) e suas vias de transporte que criam a solidariedade regional (Vidal de La Blache); a centralidade (função da cidade), a hierarquia urbana, complementaridade (áreas urbanas e rurais) e a área de abrangência do mercado (Walter Christaller); a identificação dos processos da dinâmica regional e das nodalidades (Halford Mackinder); a importância das redes de circulação e comunicação (Jean Gottmann).

Contudo, a complexidade da hierarquia urbana começou a dificultar a delimitação das regiões, sempre pensadas a partir de seus centros urbanos, e também sua definição como espaços homogêneos ou uniformes (LABASSE, 1960). O desenho das regiões administrativas mostrava-se ultrapassado conforme mudavam as dinâmicas e os vetores da regionalização (LABASSE, 1960). 
Após a Segunda Guerra Mundial, os motores do desenvolvimento e do crescimento econômico se tornam mais complexos e mais difundidos pelo mundo, configurando uma verdadeira divisão internacional do trabalho. A região passa a ser compreendida como uma particularidade do funcionamento da economia mundial, inserindo-se em diferentes escalas econômicas e políticas, e os fluxos de produtos, pessoas e informações ultrapassam, cada vez mais, os limites regionais (KAYSER, 1967).

A região ganha um caráter universal, e é definida pela relação de interdependência que estabelece com outras regiões no contexto da economia mundial, e não mais por seus processos particulares (KAYSER, 1967). Assim, a região participa de uma escala mais ampla de poder econômico e político, cujas decisões escapam aos limites regionais, tornando-a um instrumento de dominação (KAYSER, 1967). A partir daí, muitas decisões que eram tomadas no âmbito de uma região, passaram a influenciar o que ocorria em outras regiões mais distantes, sobretudo naquelas situadas em países subdesenvolvidos, ajudando a internacionalizar os ideais de desenvolvimento econômico e de planejamento no mundo (BOUDEVILLE, 1973). Conforme aponta Boudeville (1973, p.08): "na escala inter-regional ou internacional, as decisões são tomadas em uma região e aplicadas em uma outra fora de quaisquer laços hierárquicos”.

O contexto de reconstrução da Europa e do Japão e de disputa entre o modelo capitalista e o comunista valorizou sobremaneira a região como recorte privilegiado para as políticas de desenvolvimento econômico. Nessa fase, as estratégias de planejamento regional $^{37}$ ganharam força no âmbito dos Estados Nacionais.

No contexto do desenvolvimentismo capitalista, o Estado apresentava-se como agente privilegiado na condução de projetos de crescimento econômico, aumento da taxa de emprego e diminuição de desigualdades regionais (ROCHEFORT, 1998; PIQUET \& RIBEIRO, 2008).

O planejamento regional deveria servir como estratégia do Estado para ampliar a acumulação de capital, sobretudo industrial, nas diferentes regiões e não

\footnotetext{
37 "Nos meios de ação econômica e social, pensa-se cada vez mais, no desenvolvimento, em termos de planejamento do território, de regionalização.” (JUILLARD, 1965, p.224). Ainda segundo o autor, isso acontecia não apenas nos países capitalistas avançados, mas nos subdesenvolvidos e nos socialistas.
} 
apenas nos polos de crescimento, otimizando o uso e a distribuição de recursos públicos e privados, especializando os fatores de produção nas regiões e melhorando as condições de vida dos trabalhadores (ROCHEFORT, 1998). A regionalização, para essa finalidade, pode ser compreendida como uma tentativa do Estado de induzir uma nova divisão inter-regional do trabalho (LIPIETZ apud SOJA, 1993).

A estratégia da regionalização passa a ser um instrumento do Estado para promover a organização da divisão territorial do trabalho em prol do desenvolvimento econômico e social, segundo as diferentes ideologias vigentes (CORRÊA, 1997; CORRÊA, 2007), recorrendo, sobretudo, aos economistas (JUILLARD, p.225, 1965). Por vezes, a região tornou-se uma categoria ideológica do Estado, um objeto muito mais do discurso do que da prática, suscetível a projetos políticos diferentes (RAFFESTIN, 1993).

A definição da região ligou-se aos estágios do desenvolvimento econômico, à polarização de seu centro e à sua relação com o conjunto, isto é, sua integração funcional em uma economia global, sem se restringir ao espaço econômico (KAYSER, 1967). As regiões eram caracterizadas conforme as condições que ofereciam para o país alcançar um determinado padrão de desenvolvimento.

As metrópoles e polos regionais ganharam enorme peso na definição das regiões, cujo potencial de inserção na economia internacional importava mais do que o desenho dos limites regionais (JUILLARD, 1965). A metrópole regional era definida pela variedade, raridade, especialidade e qualidade de suas atividades urbanas e era cortada por importantes vias de circulação e comunicação, que garantiam a abrangência de sua influência regional (polarização) sobre outros centros urbanos e áreas agrícolas. A metrópole representava um centro de difusão das inovações e do desenvolvimento para toda a região. Cresce a importância dos fluxos regionais (KAYSER, 1967) e das hierarquias e redes urbanas para explicar a conformação da região (ROCHEFORT, 1961).

Nesse período, surge na França, a geografia econômica e aplicada, expressa pela obra de Pierre George, e a política de planejamento do território (aménagement $d u$ territoire $^{38}$ ) (CORRÊA, 2007). A identificação de espaços funcionais ao

38 Corrêa (2007) cita como referência Labasse, Jean. L'organization de l'espace; éléments de géographie volontaire. Paris, Hermann, 1966. 
desenvolvimento, coesos e coordenados pelas metrópoles regionais, definiu "regiões funcionais", onde seus limites importavam menos do que suas forças de coesão (JUILLARD, 1965). A metrópole regional apresentava certos equipamentos, a indústria e importantes vias de circulação e comunicação, e sua função era definida pela variedade de suas atividades urbanas. Ela representava um campo de ação com capacidade de decisão e impulsão, combinando diversas forças motoras regionais (JUILLARD, 1965). As regiões eram definidas por suas zonas de influência, em decorrência da raridade e especialidade dos equipamentos e serviços que sua cidade polo oferecia (LABASSE \& ROCHEFORT, 1965).

Tornam-se critérios importantes para a identificação das regiões: a hierarquia e atratividade dos centros urbanos, a densidade populacional, a concentração industrial, as funções urbanas, a diversificação dos serviços, comércio e equipamentos, a intensidade dos fluxos e as relações de complementaridade com as zonas rurais. As regiões funcionais e a articulação regional da rede urbana expressavam diretamente o padrão de desenvolvimento dos territórios: "consequência do desenvolvimento, a organização regional é, também, a sua condição. De fato, ela o traduz no espaço.” (LABASSE \& ROCHEFORT, 1965, p.236).

Os esforços da política do Estado procuraram contemplar também a escala nacional do planejamento e a polarização dos centros urbanos como base e instrumento eficaz para a integração do território. A constituição de uma rede urbana com polos irradiando os fatores de produção visava diminuir as disparidades regionais quanto ao desenvolvimento e à hierarquia urbana - aglomeração e diversificação das atividades e capacidade de inovação e difusão (BOUDEVILLE, 1973).

No contexto dos Estados de bem-estar social europeus, o planejamento regional questionou a criação dos polos de crescimento (restrito aos indicadores econômicos) e propôs a ideia de polos de desenvolvimento e regiões funcionais (PERROUX, 1981). O planejamento acabou se chocando com os desequilíbrios regionais, revelando as contradições inerentes à ideia de desenvolvimento imbuída da dicotomia econômico versus social e da exploração dos países subdesenvolvidos (PERROUX, 1981). Tais desequilíbrios eram consequência das desigualdades do 
processo de inserção das regiões na divisão internacional do trabalho - existência de centros e periferias. $\mathrm{O}$ planejamento regional questionou os polos de crescimento (restrito aos indicadores econômicos) e propôs a ideia de polos de desenvolvimento, valorizando a relação entre progresso técnico, infraestruturas, redes de transporte e comunicação, instituições e organizações de poder, condições de vida, políticas de bem-estar social, capacidade de inovação e difusão, produtividade e a articulação entre os polos de desenvolvimento de um mesmo território (PERROUX, 1981).

No caso francês, a proposta de distribuição de renda entre regiões e camadas sociais através dos polos de desenvolvimento não se efetivou integralmente, pois a expansão industrial para regiões menos atrativas ficou muito condicionada à ajuda do governo na garantia de condições básicas para o funcionamento capitalista (ROCHEFORT, 1998). Segundo o autor, a desigualdade econômica e produtiva entre as regiões resultaram em tensões sociais, que poderiam prejudicar o crescimento econômico e incentivar movimentos de oposição política ao governo do país, colocando para o Estado a questão de como diminuir tais tensões através do planejamento regional. A região, apesar de ser compreendida pelo predomínio dos vetores econômicos, mostrou-se essencialmente política (LACOSTE, 1985).

Em meados da década de 1970, com a emergência da globalização e do neoliberalismo, que propunha a crença exacerbada nas forças de mercado para impulsionar o crescimento econômico e diminuía o papel do Estado no planejamento, as estratégias de planejamento regional do desenvolvimento começaram a perder centralidade (ROCHEFORT, 1998). O debate sobre desenvolvimento foi suprimido pela ideia de competitividade, inovação tecnológica, estabilidade macroeconômica, rentabilidade financeira e reforma gerencial do Estado.

A consolidação de um mercado global, com empresas atuando em diversos países, a extensão de redes de transporte e comunicação, conformando sistemas de logística planetários, e a necessidade de inserção dos lugares nesse mercado trouxeram novos elementos para a estruturação de regiões (SANTOS, 1996).

Os motores da divisão internacional do trabalho foram atualizados pela unicidade da técnica e das estratégias de acumulação capitalista mundial, com a difusão do meio técnico-científico-informacional, o imperativo das finanças, da 
fluidez, da informação e das inovações sobre a produção e o consumo (SANTOS, 1996).

Ao mesmo tempo, as mudanças técnicas, políticas, econômicas e culturais que vinham ocorrendo no mundo, desde o pós-guerra, tornaram mais complexa a tarefa de identificação de regiões. No período da globalização, houve declarações sobre a "morte" da região, dado o volume e a complexidade dos eventos nos lugares e à nova ideologia da relação "local-global" no contexto do Estado mínimo (neoliberalismo). Outros temas emergiram, tais como a questão urbana e a relação “local-global” (PIQUET \& RIBEIRO, 2008) e o “desenvolvimento local” (BOISIER, 2001).

As teorias baseadas na perspectiva "local-global" também definiram o "espaço das redes" ou "espaço dos fluxos", considerando a difusão mundialmente densa e extensa das redes de transporte e informação (CASTELLS, 1999). Mas a tese da "morte" das regiões foi rapidamente contestada. A globalização aprofundou tal fenômeno geográfico e impôs a necessidade de novas variáveis-chave para explicá-lo (SANTOS, 1996).

A região passou a abrigar um número maior de mediações das ações, em diferentes escalas de espaço e tempo, sob uma mesma lógica produtiva, que estrutura uma solidariedade organizacional ${ }^{39}$ entre os lugares (SANTOS, 1996). Trata-se de um acontecer solidário, mas não homogêneo, que depende de ações realizadas em diferentes escalas, contextualizado pela totalidade do mundo e pela situação geográfica dos lugares. Isso altera sua forma e conteúdo, tornando-a um compartimento espacial conveniente ao mercado global (SANTOS, 1994).

Nesse novo contexto, a região é definida pela coerência funcional entre sua base técnica (equipamentos, infraestrutura, acessibilidade), organizacional (leis locais, impostos, relações trabalhistas), produtiva (eficácia mercantil e fluidez para um determinado produto), informacional (fluxos imateriais que comandam a produção) e comunicacional (cotidiano, co-presença), que caracteriza sua capacidade de oferecer rentabilidade aos investimentos e determina seu papel na divisão internacional do trabalho - regiões do mandar e regiões do fazer (SANTOS, 1994).

\footnotetext{
39 A solidariedade organizacional está baseada na existência de coerências funcionais entre lugares, não necessariamente contíguos, que se relacionam a partir de suas funções na divisão territorial do trabalho (Santos, 1996).
} 
A preocupação central é, portanto, entender os processos, as coerências e não mais os limites regionais: "a região aí está, porém com um nível de complexidade jamais visto pelo homem" (SANTOS, 1994).

As regiões contemporâneas resultam de dois recortes espaciais superpostos: as verticalidades e as horizontalidades (SANTOS, 1996). A divisão internacional do trabalho supõe ações hierárquicas (verticais), que criam solidariedades organizacionais entre lugares distantes e conectados por redes de circulação e comunicação. Ao mesmo tempo, essa divisão supõe ações homólogas e complementares (horizontais), que criam solidariedades orgânicas entre lugares contíguos. A formação das regiões contemporâneas é dada pela proximidade espacial (co-presença; horizontalidades) e pela proximidade organizacional (teleação; verticalidades).

As redes de circulação e informação funcionam como instrumentos das ações verticais, "incumbem-se de transportar o universo ao local, unindo diferentes pontos ou regiões numa mesma lógica produtiva" (SANTOS, 2005). Entretanto, quando as redes se integram nos lugares por meio do trabalho e das diferentes ações que se criam a partir delas, "se estabelece a co-presença num espaço contínuo" (SANTOS, 2005).

As constantes e aceleradas transformações na divisão internacional do trabalho encurtam o tempo de elaboração e duração dos conteúdos e formas regionais, mas permanece a definição da região como um recorte territorial (SANTOS, 1994, p.157). A região é, portanto, um conceito dinâmico, "tecido contínuo e heterogêneo de modernidades e formas herdadas", exprime uma base técnica e política que se caracteriza pela "falta de coincidência entre as escalas da técnica e da política" (SILVEIRA, 2010).

Nesse contexto, as grandes empresas passaram a selecionar as regiões que mais interessavam para organizar novas lógicas de produção e comercialização dos produtos em escala planetária. As regiões ganhadoras (BENKO \& LIPIETZ, 1994), consideradas as mais aptas para viabilizar a produção de bens exportáveis, começaram a receber grandiosos investimentos públicos e privados. A identificação dessas regiões pelas grandes empresas gerou grande competitividade entre lugares no mundo para serem classificados com boas opções para investimentos. As regiões 
passaram a se organizar como "vitrines para o mercado global" (SILVA NETO, 2003, p.363).

Essas mudanças colocam em evidência os lugares com maior capacidade de conexão com o mercado internacional - conexões geográficas - rompendo com a tradicional lógica da hierarquia da rede urbana e da contiguidade regional (SOUZA, 1995).

As regiões competitivas (CASTILLO, 2008) especializaram-se nos parâmetros produtivos internacionais de qualidade e custo, sendo a fluidez territorial intermodal uma variável-chave nesse processo, tornando a competição não apenas um atributo da empresa, mas também da região. O novo paradigma produtivo aproximou ainda mais as noções de região e de rede (circulação e comunicação), evidenciando os embates entre a dinâmica territorial e a logística das redes (Ibidem, 2008). Competitividade, rentabilidade e fluidez tornaram-se atributos não apenas das empresas, mas, também, das regiões.

Verifica-se que a definição dos limites (desenhos) regionais importa cada vez menos para se identificar e compreender uma região geográfica. A organização de diversos elementos para oferecer competitividade e rentabilidade às empresas atuantes no mercado global e as amplas conexões que o polo urbano regional estabelece com outras cidades, não necessariamente contíguas no território, são as principais questões que estruturam as regiões (SANTOS, 2008). A região é, assim, um recorte dinâmico dos usos do território que sofre influência de ações que ocorrem em diferentes escalas de tempo e espaço (SILVEIRA, 2010).

Contudo, nem todos os lugares, nem todas as pessoas e empresas participam e se beneficiam igualmente das condições regionais de produção, circulação e consumo, nessa lógica competitiva. Na contiguidade da região, o cotidiano revela conflitos e contradições que resultam das desigualdades socioespaciais, como consequência da lógica competitiva na qual os lugares se inserem e da falta de elaboração de políticas públicas regionais visando à diminuição das desigualdades.

Desde o início do século XX, o conceito de região vem sendo atualizado pelas teorias econômicas e geográficas, apresentando pontos de interseção e distinção, sendo possível distinguir diferentes fases da evolução do conceito conforme mudam os motores da divisão territorial do trabalho no mundo (Quadro 1). 


\section{Quadro 1 - Contribuições da Geografia e da Economia para a identificação de regiões}

\begin{tabular}{|c|c|}
\hline \multicolumn{2}{|c|}{ Início do século XX até 1950} \\
\hline Geografia & Economia \\
\hline $\begin{array}{l}\text { Identificação de regiões através da existência de um centro } \\
\text { (cidade) e suas vias de transporte. } \\
\text { Elementos: } \\
\text { - Centralidade da cidade na hierarquia urbana, dada a } \\
\text { diversidade e qualidade dos seus serviços e equipamentos } \\
\text { urbanos; } \\
\text { - Complementaridade entre áreas urbanas e rurais e a área de } \\
\text { abrangência do mercado regional; } \\
\text { - Identificação da dinâmica regional e seus nós, isto é, suas } \\
\text { cidades de referência; } \\
\text { - Importância das redes de circulação e comunicação }\end{array}$ & $\begin{array}{l}\text { Identificação de regiões através do } \\
\text { padrão de localização industrial e } \\
\text { das atividades agrícolas. } \\
\text { Elementos: } \\
\text { - Fatores de produção (renda da } \\
\text { terra, custo dos transportes e } \\
\text { matérias-primas); } \\
\text { - Mercado consumidor; } \\
\text { - Atividades urbanas. }\end{array}$ \\
\hline \multicolumn{2}{|c|}{ De 1950 até meados da década de 1970} \\
\hline Geografia & Economia \\
\hline $\begin{array}{l}\text { Identificação de regiões através da polarização da rede urbana } \\
\text { e dos fluxos entre zonas rurais e urbanas. } \\
\text { Elementos: } \\
\text { - Hierarquia, atratividade e polarização dos centros urbanos; } \\
\text { - Densidade populacional; } \\
\text { - Concentração industrial; } \\
\text { - Funções urbanas, diversificação dos serviços, da produção e } \\
\text { dos equipamentos; } \\
\text { - Intensidade dos fluxos; } \\
\text { - Relações de complementaridade com as zonas rurais e outras } \\
\text { regiões industriais e urbanas. }\end{array}$ & $\begin{array}{l}\text { Identificação das regiões através de } \\
\text { polos de crescimento e polos de } \\
\text { desenvolvimento. } \\
\text { Elementos (polos de crescimento): } \\
\text { - Desconcentração e concentração } \\
\text { industrial e agrícola (aglomerações } \\
\text { produtivas) } \\
\text { - Constituição de uma rede urbana } \\
\text { com polos irradiando os fatores de } \\
\text { produção; } \\
\text { - Desequilíbrios regionais (sociais e } \\
\text { setoriais), existência de centros e } \\
\text { periferias. } \\
\text { Elementos (polos de } \\
\text { desenvolvimento): } \\
\text { - Infraestrutura urbana e de } \\
\text { produção; } \\
\text { - Redes de transporte e } \\
\text { comunicação; } \\
\text { - Instituições e organizações } \\
\text { políticas; } \\
\text { - Condições de vida da população; } \\
\text { - Políticas de bem-estar social; } \\
\text { - Políticas de crescimento } \\
\text { econômico; } \\
\text { - Capacidade de inovação e difusão } \\
\text { tecnológica; } \\
\text { - Produtividade e a articulação entre } \\
\text { os polos de desenvolvimento de um } \\
\text { mesmo território }\end{array}$ \\
\hline \multicolumn{2}{|c|}{ De meados da década de 70 até os anos 2000} \\
\hline Geografia & Economia \\
\hline $\begin{array}{l}\text { Identificação de regiões através de sua capacidade de oferecer } \\
\text { competitividade às empresas no mercado mundial. } \\
\text { Identificação de regiões como um recorte dinâmico dos usos } \\
\text { do território, que sofre influência de ações que ocorrem em } \\
\text { diferentes escalas de tempo e espaço. }\end{array}$ & $\begin{array}{l}\text { Identificação de regiões através de } \\
\text { sua capacidade de oferecer } \\
\text { competitividade às empresas no } \\
\text { mercado global. }\end{array}$ \\
\hline
\end{tabular}




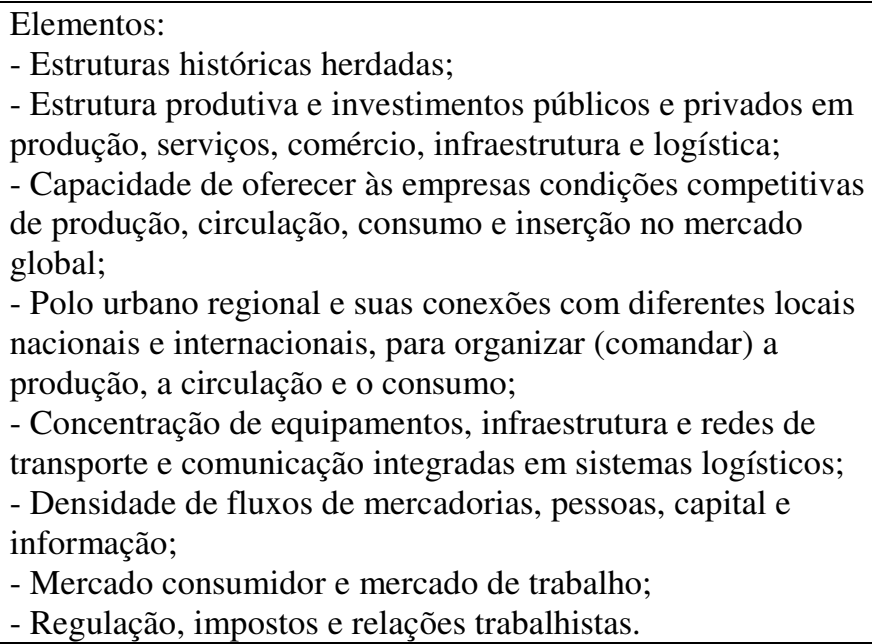

A partir dos anos 2000

Identificação de regiões através de sua capacidade de oferecer competitividade às empresas no mercado mundial e, também, de seu papel na reprodução das desigualdades socioespaciais resultantes da modernização do território.

Novos elementos que se somam aqueles definidos a partir de meados da década de 70:

- Conflitos e contradições que resultam das desigualdades socioespaciais;

- Diferentes grupos sociais que reivindicam sua participação no planejamento regional.
Elementos:

- Capacidade de produção e comercialização dos produtos no mercado global;

- Concentração de investimentos públicos e privados em infraestrutura, serviços, ciência, tecnologia e inovação;

- Capacidade de garantir competitividade para as empresas no mercado nacional e global; - Mercado de trabalho e regulação trabalhista;

- Conexão local-global;
Identificação de regiões através de sua capacidade de inserção numa nova política de desenvolvimento econômico e social.

Novos elementos que se somam aqueles definidos a partir de meados da década de 70:

- Mercado consumidor interno;

- Capacidade produtiva da indústria nacional;

- Níveis de desigualdade econômica e social.

Elaboração própria (adaptado de LIMA et al., 2012a).

A Região é uma categoria de análise da Geografia, entretanto, a elaboração de um conceito para embasar as práticas de regionalização (planejamento) tem sido influenciada, sobretudo, pela Economia, já que se trata de uma tentativa do Estado de coordenar a divisão territorial do trabalho em prol do desenvolvimento econômico.

A Geografia e a Economia apontam para a necessidade de se tratar os processos regionais de forma multiescalar, compreendendo que as regiões participam de projetos e ações que dependem de fatores e grupos de interesses diversos. Muitas vezes, esses processos escapam aos limites regionais, sobretudo, no período da globalização.

A Geografia, por sua vez, tende a olhar para a totalidade dos usos do território e não apenas para aqueles que caracterizam a competitividade das regiões. Apontando o papel de cada região na reprodução das desigualdades socioespaciais. Nesse sentido, a Geografia aponta para as limitações da capacidade do Estado de induzir uma racionalidade espacial ao projeto de desenvolvimento, dado que o 
território usado é uma acumulação desigual de eventos e cria resistência para as ações e políticas (SANTOS, 1996). Outra questão fundamental recai sobre a complexidade das redes geográficas e sua difusão acelerada no mundo contemporâneo. As redes são elementos estruturadores das regiões ${ }^{40}$ contemporâneas e trazem conteúdos e interesses mundiais para os lugares, dificultando o comando estatal sobre a divisão territorial do trabalho.

\subsection{As regiões e as redes geográficas}

Rede é um conceito antigo, que diz respeito à criação de malhas (linhas e pontos articulados), que permitem a conexão entre os lugares e a fluidez territorial circulação material (pessoas e mercadorias) e imaterial (normas, informações, finanças). Hipócrates (séc.V a.C.) definiu as redes a partir de sua matriz orgânica, isto é, relacionada ao corpo humano, e Saint-Simon, em meados do século XVIII, definiu a matriz moderna do conceito de redes técnicas (Dias, 2007). Ao longo da evolução dos sistemas técnicos, as redes de circulação e comunicação passaram a ser compreendidas como mediações técnicas das transformações sociais (DIAS, 2007).

O desenvolvimento técnico possibilita, cada vez mais, o caráter deliberado de criação e traçado das redes no território (SANTOS, 1996). Com os avanços da ciência, da tecnologia e da informação, "a montagem das redes supõem uma antevisão das funções que poderão exercer e isso tanto inclui a sua forma material, como as suas regras de gestão" (SANTOS, 1996, p.211).

O debate contemporâneo está pautado, por um lado, pela densa e extensa difusão das redes, configurando uma malha planetária, especialmente facilitada pelos avanços tecnológicos das redes de comunicação e informação. Por outro lado, aborda as transformações sociais decorrentes da configuração dessa malha, sobretudo no que se refere às ações produtivas e às relações de poder que elas viabilizam no território (RAFFESTIN, 1993; SANTOS, 1996; CASTELLS, 1999). Neste caso, predomina o foco na ação dos agentes hegemônicos da economia capitalista, tais como as grandes empresas privadas, por serem aqueles que detêm maior poder sobre o desenho, a organização, a administração, a regulação, a inovação e o uso das redes. Por vezes, o

\footnotetext{
${ }^{40}$ Vidal de La Blache, em 1920, já havia alertado sobre a intrínseca relação entre expansão das redes ferroviárias e a criação das regiões na França.
} 
debate contemporâneo também é marcado pelo determinismo técnico das redes sobre as transformações sociais e não o contrário.

As redes criam e recriam arranjos técnicos e institucionais, combinando diferentes escalas de ação (local, regional, nacional e mundial), tornando mais complexas as interações socioespaciais (DIAS, 2007). Trata-se de uma materialidade (face visível) e ação (face invisível), organizada hierarquicamente e que permite integrar e criar coesões no território, construindo relações de poder “toda rede é uma imagem do poder" (RAFFESTIN, 1993, P.157). Constituem uma “malha de duplo controle, técnico e político" (BECKER \& EGLER, 2003, p.145).

O suporte das redes são pontos ativados, cuja topografia ultrapassa as fronteiras nacionais, criando conectividade dos lugares com o mundo, uma sociabilidade à distância que traz conteúdos do mundo aos lugares e vice-versa (SANTOS, 1996). De acordo com o autor, a instalação de seus pontos ocorre em diferentes momentos e é condicionada pelo contexto da história complexa da evolução dos lugares e regiões; quando instaladas, possibilitam rapidez, instantaneidade e simultaneidade das ações.

As redes se superpõem num mesmo subespaço, ajudando a comandar as mudanças na divisão territorial do trabalho, nos conteúdos regionais, e "seriam incompreensíveis se apenas as enxergássemos a partir de suas manifestações locais ou regionais" (SANTOS, 1996, p.215). As redes criam diferentes escalas de solidariedade geográfica ${ }^{41}$, mundial, nacional, regional e local, e tornam mais complexa a divisão territorial do trabalho (CASTILLO et al, 1997). Nos lugares e regiões, elas se integram aos demais fenômenos socioespaciais e exercem seu papel de integração funcional e territorial. As redes tornam mais complexa a ideia de região e regionalização no período da globalização.

A configuração pesa diferentemente nos diversos lugares, segundo seu conteúdo material. É a sociedade nacional, através dos mecanismos de poder, que distribui, no país, os conteúdos técnicos e funcionais, deixando os lugares envelhecer ou tornando possível sua modernização. Através das relações gerais direta ou indiretamente impostos a cada ponto do país, seja pela via legislativa ou orçamentária ou pelo exercício do

\footnotetext{
${ }^{41}$ Sobre a discussão do conceito de solidariedades geográficas, como expressão das diferentes formas de relação entre os lugares e as regiões no âmbito da divisão territorial do trabalho, ver Santos (1996) e Castillo et al (1997).
} 
plano, a sociedade nacional pesa com seu peso político sobre a parcela local da configuração geográfica e a correspondente parcela local da sociedade, através das qualificações de uso da materialidade imóvel e duradoura. (...) $\mathrm{O}$ trabalho local depende das infraestruturas localmente existentes e do processo nacional de divisão do trabalho nacional. (SANTOS, 1996, p.217).

A densidade e diversidade das redes nas regiões ajudam a definir sua especialização produtiva, seu grau de fluidez e competitividade, e seu poder como centro de decisão (polarização e comando). Daí a importância das redes para a conformação das hierarquias urbanas e conexões geográficas no território (ROCHEFORT, 1982; SOUZA, 1995).

As redes estruturam e comandam a divisão territorial e internacional do trabalho, especializando e solidarizando os lugares. São objetos técnicos e políticos, que ajudam a conformar as regiões do mandar e do fazer (SANTOS \& SILVEIRA, 2001) e as regiões competitivas (CASTILLO, 2008). As redes também abrigam círculos de cooperação política, social e produtiva, que viabilizam uma série de usos do território e a própria coerência funcional das regiões. A rede oferece suporte ao poder, aos círculos de cooperação.

A divisão do trabalho e a edificação das regiões são condicionadas pela capacidade de renovação técnica ${ }^{42}$ das redes e de atualização dos círculos de cooperação política dos lugares. Tais renovações mudam o valor dos lugares, garantindo maior ou menor poder e competitividade das regiões.

As redes são importantes para a difusão de tecnologias no território, assim como, de informações que organizam a produção, os fluxos e o consumo. Elas viabilizam a inovação e lógica de incorporação tecnológica nos lugares, muitas vezes desconsiderando as demandas e desigualdades regionais. Os agentes que organizam as redes têm grande poder técnico, político e econômico de comando sobre a divisão territorial do trabalho e a difusão de inovações, tecnologias e informações no território. Esses agentes pertencem aos setores mais corporativos da economia, que se utilizam de estratégias verticais de atuação no território, isto é, atuação em rede (MANZONI NETO \& SILVA BERNARDES, 2008).

\footnotetext{
42 "Nessas condições, a tendência atual é de um envelhecimento mais rápido do que antes dos subespaços que não dispõem dos meios de se atualizar, de um ponto de vista da fluidez. (...) Dentro de uma cidade, o mesmo processo de envelhecimento rápido é mais rápido em certos bairros do que em outros." (SANTOS, 1996, p.218-219)
} 
O planejamento regional tem nas redes (urbana, comunicação, transporte, energia, informação, pesquisa e desenvolvimento, institucionais) um de seus principais elementos para organizar regiões. As redes organizam regiões, ao mesmo tempo em que tornam mais complexa a ideia de regionalizar o território, dado que as redes inserem os lugares na divisão internacional do trabalho.

\subsection{Regionalização e planejamento regional no Brasil: breve resgate histórico, aprendizados e desafios}

No início do século $\mathrm{XX}$, surgem as primeiras tentativas de elaboração de modelos de divisão regional do território brasileiro, para fins de interpretação teórica da dinâmica espacial e planejamento estatal (GUIMARÃES, 1942; MAGNAGO, 1995).

Na primeira metade do século, os modelos de divisão regional do país sofreram grande influência do conceito de região natural, enfatizando a correlação dos elementos físicos (clima, relevo, hidrografia, vegetação). Não refletindo ainda a evolução do conceito de região geográfica proposto por Vidal de La Blache.

Em 1913, Delgado de Carvalho divide o Brasil em cinco macrorregiões naturais, considerando as relações entre o relevo, o clima e a vegetação, para fins didáticos do ensino de geografia, servindo de referência para os estudos e pesquisas realizados até a década de 1930 (MAGNAGO, 1995).

A partir da década de 1930, inicia-se o processo de modernização centralizadora do país, que vincula o projeto nacional a um Estado forte e diminui as autonomias estaduais, racionaliza a burocracia estatal e cria um sistema de informações estatísticas ${ }^{43}$ confiáveis sobre o território brasileiro, para fins de planejamento (COSTA, 1988). O desenvolvimento passou a ser sinônimo de industrialização e a política de criação de um parque industrial moderno, por meio da articulação entre capital estatal e capital privado, e de expansão do mercado interno resultou na tomada de consciência sobre a "gravidade dos desequilíbrios regionais

\footnotetext{
${ }^{43}$ Em 1933, é criado o Conselho Nacional de Geografia; em 1934, é criado o Instituto Nacional de Estatísticas; em 1942, estes dois órgãos são unidos na criação do Instituto Brasileiro de Geografia e Estatística (IBGE). (COSTA, 1988).
} 
que vinham produzindo uma industrialização concentrada em uma área limitada do território nacional" (FURTADO, 1999, p. 49).

Com o Estado Novo (1937-45), autoritário, centralizador, focado no progresso e na construção da nação, inicia-se o planejamento governamental e a elaboração de políticas territoriais para dirigir o processo de industrialização do país e integrar o território, legitimando a ação do Estado (BECKER E EGLER, 2003). Havia a necessidade de investimentos públicos para alargar as bases produtivas industriais e estender as redes de transporte, energia e comunicação, para integrar o "sertão" às áreas economicamente mais dinâmicas. Os "arquipélagos", isto é, as regiões que funcionavam a partir de uma conexão direta com o mercado internacional, através das atividades agrário-exportadoras ${ }^{44}$ (café, fumo, borracha, cacau e açúcar), e estavam pouco articuladas internamente por conta da escassez de redes de transporte e comunicação, deveriam ser integradas, constituindo um mercado interno (FURTADO, 1959). Essas regiões também eram denominadas "arquipélagos" por conta da escassa rede de transporte e comunicação para integrálas nacionalmente (SILVA, 1966).

Nesse contexto, o poder público começa a incorporar a técnica de planejamento como instrumento de política econômica, para conferir maior racionalidade na organização das informações, análise de problemas e tomada de decisões (IANNI, 1971). Assim, surgiu a necessidade de definição de uma divisão regional brasileira oficial para servir de referência para a produção e a comparação de estatísticas, que possibilitassem um conhecimento prático para o planejamento do território.

Em 1941, Fábio de Macedo Guimarães, chefe da seção de estudos geográficos do IBGE, elaborou a primeira divisão regional oficial do Brasil para fins de planejamento do território. Para tanto, considerou que "a divisão prática ideal é a que se aproxime o mais possível da divisão em "regiões naturais"”, por reunirem características mais uniformes, "mesmo que tal aproximação não seja possível por motivos de ordem administrativa e econômica", garantindo a inclusão dos estados em cada região (GUIMARÃES, 1942, p.08). Conforme enfatizou o autor, o

\footnotetext{
44 Furtado (1959) definiu cinco grandes regiões segundo as atividades agrário-exportadoras no período: Centro (cafeeiro); Nordeste (açucareiro e algodoeiro); Bahia (açúcar, fumo e cacau); Sul (pecuária e charque); Amazônia (borracha).
} 
"essencial é que haja uniformidade, principalmente para fins estatísticos" (p.08), fixando "uma única divisão regional prática (...) base para a solução do problema prático" (p.09). A região natural garantiria certa estabilidade (quadros fixos) para os estudos estatísticos e comparações regionais sobre a evolução do país, em diversas épocas, ao contrário de regiões humanas, que permitiriam um estudo sobre a situação conjuntural do país, já que são sujeitas às constantes modificações dos fatos econômicos

A primeira divisão regional oficial do Brasil identificou macrorregiões com base nas regiões naturais (traços comuns dos fatores: clima, vegetação e relevo, além da posição geográfica), considerando a divisão regional realizada em 1913 por Delgado de Carvalho, sem desmembrar as unidades políticas, atendendo às necessidades da administração pública (resolução $\mathrm{n}^{\circ}$ 72, de 14 de julho de 1941; circular $n^{\circ} 1$ de 31 de janeiro de 1942). Essa divisão em Norte, Nordeste, Leste, Sul e Centro-Oeste adotada por todos os ministérios, seria atualizada nos anos seguintes por conta da criação de novas unidades político-administrativas (territórios federais). Antes disso, foram elaborados outros zoneamentos com objetivos específicos, para serem utilizados por órgãos públicos e privados, com destaque para: o zoneamento dos tipos regionais de alimentos, de Josué de Castro (1937); o zoneamento da fisionomia econômica brasileira, de Hugo Hamann (1939); o zoneamento para elaboração do anuário estatístico brasileiro, do Ministério da Agricultura (1938); e o zoneamento geoeconômico, do Conselho Técnico de Economia e Finanças (1939) (MAGNAGO, 1995).

Durante o Estado Novo foram elaboradas algumas medidas pontuais e conjunturais para o Nordeste e a Amazônia, sem caracterizar um planejamento regional abrangente: a criação do Banco de Crédito da Borracha (1942), para fortalecer as exportações da borracha na Amazônia; e a criação da Comissão do Vale do São Francisco e da Companhia Hidro Elétrica do São Francisco (1945-48), para combater as secas nordestinas e aproveitar o potencial hidrelétrico da região (COSTA, 1988).

Foi na década de 1950 que a "questão regional" despontou com força na literatura e na política brasileira, associada ao problema das desigualdades regionais, 
com foco principalmente no Nordeste (ARAÚJO, 2001), concomitantemente ao surgimento do debate sobre o desenvolvimento nacional.

Nesse contexto, o conceito de região natural deixa de ser central no planejamento brasileiro, dando lugar às concepções de região geográfica (polarizada ou funcional), resultado do dinamismo da divisão territorial do trabalho, e de região operacional, como uma unidade de coordenação e implantação de um programa de desenvolvimento (SOUZA, 1976). O planejamento regional deveria possibilitar uma intervenção estatal na divisão territorial do trabalho, organizando e potencializando os motores do desenvolvimento econômico: a industrialização, a urbanização, as redes de energia, transporte e comunicação e a integração do mercado interno. De acordo com Souza (1976, p.107), “o binômio cidade-região, passa a se constituir no elemento de manipulação do processo de planejamento".

Os modelos de divisão regional do país sofrem duas principais influências: (i) do aménagement du territoire francês, baseado nas teorias geográficas, econômicas, história e ciências sociais sobre a relação entre funções urbanas, as redes, a hierarquia urbana e o desenvolvimento regional (polos de desenvolvimento e áreas metropolitanas); (ii) do regional planning americano, baseado nas teorias econômicas de difusão espacial das inovações e das atividades produtivas (economias de aglomeração), sobretudo, em relação às atividades industriais (atratividade, localização, concentração, desequilíbrios) (ANDRADE, 1973; SOUZA, 1976; MAGNAGO, 1995; CANO, 2000; SILVA NETO, 2003; MORAES, 2005).

No planejamento, o território brasileiro passa a ser visto como um instrumento e um produto do capitalismo nacional, organizado a partir de “estratégias espaciais implícitas e explícitas do Estado" (BECKER \& EGLER, 2003, p.86). O desenvolvimento torna-se sinônimo de industrialização, apoiada pelo tripé entre capital privado nacional (bens não duráveis), capital estrangeiro (bens duráveis) e capital estatal (bens de produção) (EVANS, 1982), e de urbanização, apoiada pelo crescimento áreas metropolitanas, como importantes mercados produtores e consumidores dos produtos industriais.

A política regional teria que lidar com o mercado nacional, industrial e urbano, concentrado espacialmente no Sudeste e nas áreas metropolitanas, que 
conformava uma nova divisão territorial do trabalho, marcada por desigualdades que distinguiam: centros dinâmicos, periferias deprimidas e fronteiras de recursos (BECKER \& EGLER, 2003).

A Comissão Econômica para a América Latina e o Caribe (Cepal), criada em 1948, teve papel preponderante na formulação do pensamento desenvolvimentista ${ }^{45}$ brasileiro e no planejamento regional. A Cepal trouxe novos conteúdos teóricos e políticos para a formulação do planejamento brasileiro, embasados pelo desenvolvimentismo e pela valorização do papel do Estado, incentivando a elaboração de planos de desenvolvimento regional (CANO, 2000). Destacam-se os trabalhos de Celso Furtado, mais especificamente, a criação da Superintendência de Desenvolvimento do Nordeste (Sudene).

O Plano de Metas (1956) havia acentuado a concentração econômica no território e a integração vertical da indústria no Sudeste (BECKER \& EGLER, 2003), por isso Furtado questiona o processo de industrialização e a política de desenvolvimento do país alegando que, sem um planejamento do Estado com foco na “questão regional”, tenderia à ampliação das desigualdades regionais, em especial entre o Sudeste (industrial) e o Nordeste (agrário), daí a importância da "questão nordestina" (ARAÚJO, 2001). A criação da Sudene trazia uma "preocupação explícita com o desenvolvimento industrial, associada a uma maior interferência estatal na economia" ao mesmo tempo em que "o Nordeste se impõe ao Governo Federal como um problema que exige sua intervenção de modo mais efetivo e

\footnotetext{
${ }^{45} \mathrm{O}$ desenvolvimentismo é uma corrente de pensamento que alcançou seu auge na década de 1950 , associada às 'teorias cepalinas', referência aos pensadores que integravam a Comissão Econômica para a América Latina e o Caribe (Cepal), como Raul Prebish e Celso Furtado, entre outros. Os elementos centrais do desenvolvimentismo são: 1) a noção de que o subdesenvolvimento não constitui uma etapa prévia pela qual os países teriam necessariamente de passar antes de chegarem à condição de desenvolvidos, mas algo decorrente da maneira desigual pela qual se dá o processo de assimilação do progresso tecnológico por parte das diferentes nações no sistema capitalista; 2) a ideia de que a posição dominante ocupada pelos países desenvolvidos (ou 'centrais') em relação à geração e à difusão da tecnologia tenderia a fazer com que os países subdesenvolvidos (ou 'periféricos') permanecessem em uma situação de dependência, exportando matérias primas e importando produtos de elevado conteúdo tecnológico e alto valor agregado. Esse movimento seria amplificado adicionalmente pela tendência à reprodução, pelas elites dos países periféricos, de padrões de consumo originados nos países desenvolvidos por meio das importações de produtos industrializados, dificultando o surgimento de polos de geração de tecnologia na periferia. O principal caminho para a superação da dependência e da própria condição de subdesenvolvimento seria a industrialização, já que a indústria é a atividade econômica com maior capacidade de estimular o progresso tecnológico. Assim, as técnicas de planejamento passaram a ser valorizadas como base para a elaboração e execução de planos nacionais de desenvolvimento conduzidos pelo Estado. (LIMA et al, 2012, p.25).
} 
sistemático, devido ao agravamento das tensões sociais e políticas da região no decorrer da década de 50" (COHN, 1978, p. 64).

Uma das propostas centrais da Sudene ${ }^{46}$ era promover a industrialização na região, de forma a criar uma burguesia industrial para enfrentar as velhas estruturas agrárias e políticas que perpetuavam o empobrecimento nordestino (ARAÚJO, 2001). Contudo, a industrialização acabou sendo promovida pelos investimentos da burguesia industrial de outras regiões do país e multinacionais, com exceção do Ceará, cujos empresários tomaram a frente do processo. E a questão social não foi enfrentada pela Sudene, por conta de interesses das elites econômicas e políticas nacionais e internacionais, que isolaram a atuação dos movimentos populares (OLIVEIRA, 1977). O projeto foi derrotado com o golpe de 1964.

Durante o regime militar, as políticas regionais explícitas adotadas pelo governo brasileiro no Nordeste e na Amazônia, a partir de um conjunto de planos, incentivos e investimentos públicos e privados, provocaram uma nova dinâmica econômica regional, integrando-as à dinâmica nacional e criando condições para o enfrentamento das desigualdades econômicas, mas não sociais, expressando uma modernização conservadora (ARAÚJO, 2001).

Os planos de desenvolvimento econômico tinham como objetivo a industrialização do país, a integração do território e do mercado interno e o fortalecimento da soberania do Estado e de sua aliança com a burguesia industrial. Esses objetivos estavam associados às metas internacionais de expansão e fortalecimento do capitalismo e das corporações mundiais, concretizados na figura dos Estados Unidos. As instituições internacionais criadas pós-II Guerra Mundial tiveram papel fundamental e preponderante na difusão da ideologia do desenvolvimento capitalista que permeava os planos brasileiros. A criação da Organização dos Estados Americanos em 1948, e a difusão de seus documentos (atas, cartas e tratados), começando pela Ata de Bogotá (OEA, 1960), deixaram claro que havia a intenção do estabelecimento de um "Plano Marshall" para a América Latina.

\footnotetext{
${ }^{46}$ A Sudene foi criada em 1959, pela lei $\mathrm{n}^{\mathrm{o}}$ 3.692, de 15 de dezembro. Sobre o processo de criação e evolução dos trabalhos da Sudene ver: Oliveira, 1977 e Cohn, 1978.
} 
Os fundamentos das estratégias territoriais do período militar constam na obra Geopolítica e poder, do general Golbery do Couto e Silva (1966): integração, ocupação efetiva e valorização do território nacional; valorização da posição geopolítica do Brasil; valorização de núcleos urbanos populosos, industrializados, dinâmicos e tecnologicamente adiantados; aumento do poder e da segurança nacional; aumento do grau de desenvolvimento tecnológico; produção de estudos de avaliação do potencial estratégico das "áreas geopolíticas" (grandes regiões), em termos físicos, econômicos, políticos e militares; centralização do planejamento e das informações estratégicas.

As demandas de produção e consumo do centro industrial do país e a expansão das redes de infraestrutura (transportes, comunicação, energia) e das cidades tornaram-se os principais motores da divisão territorial do trabalho e vetores de integração do território e do mercado interno. A integração territorial servia também como um "recurso ideológico essencial utilizado para ampliar o controle do território nacional e encobrir as políticas seletivas espaciais e sociais", para criar a ideia de "Brasil potência", abafando setores populares e reforçando um desenvolvimento centralizador e excludente (BECKER \& EGLER, 2003, p.126). Outro ponto essencial da política de desenvolvimento nessa fase foi a busca pela autonomia tecnológica em setores estratégicos (aeronáutica, indústria bélica, nuclear e de computação), que levou ao surgimento de uma fronteira tecnológica na região Centro-Sul, muito bem caracterizada pela concentração de investimentos públicos e privados na região do Vale do Paraíba (BECKER \& EGLER, 2003).

Durante o regime militar, foram criadas mais três superintendências de desenvolvimento regional - a Superintendência do Desenvolvimento da Amazônia (Sudam), em 1966 e a Superintendência de Desenvolvimento do Centro-Oeste (Sudeco) e a Superintendência do Desenvolvimento da Região Sul (Sudesul) em 1967 - com o objetivo de ocupar "vazios territoriais", promover a industrialização e o maior controle das fronteiras internacionais, cooptando as oligarquias regionais através de um novo pacto de modernização patrocinado por grandes incentivos governamentais (BECKER \& EGLER, 2003). Essa divisão das superintendências reflete as mudanças na regionalização oficial do país, constituída por cinco 
macrorregiões $^{47}$, elaborada pelo IBGE em 1967 e institucionalizada pelo Decreto $\mathrm{n}^{\circ}$ 67.647 de 23/11/1970.

O I Plano Nacional de Desenvolvimento (I PND, 1971-74) focou na integração nacional com base no desenvolvimento regional, visando a articulação entre recursos abundantes e ociosos nas distintas regiões, com destaque para a criação dos polos de desenvolvimento no Nordeste, Centro-Oeste e na Amazônia (SOUZA, 2004). Mas foi o II Plano Nacional de Desenvolvimento (II PND, 197579) que consolidou o projeto de planejamento territorial segundo os objetivos governamentais vigentes, através de duas principais estratégias, mais seletivas e subregionais ${ }^{48}$ : organização, desconcentração e expansão da rede urbana; e a criação de polos de desenvolvimento (BECKER \& EGLER, 2003).

Em 1973, foram criadas oito ${ }^{49}$ Regiões Metropolitanas (Lei Complementar 14/73), sob o comando do governo estadual e com financiamento federal, cujo objetivo era promover a elaboração do Plano de Desenvolvimento integrado e a programação dos serviços comuns, conforme os programas e projetos de interesse metropolitano. O II PND privilegiou o desenvolvimento urbano e industrial como categorias essenciais para a definição das Regiões Metropolitanas (SOUZA, 1992). Havia duas preocupações centrais: a primeira com a criação de uma rede urbana hierarquizada (sistema urbano), como forma de ocupar o território e promover a articulação entre os polos de desenvolvimento; e a segunda, que acabou prevalecendo na política nacional, com o desenvolvimento intra-urbano (SOUZA, 2004). O foco nas regiões metropolitanas indicava, entretanto, uma reorientação da visão federal sobre o planejamento territorial, que deixava de centralizar as ações na

\footnotetext{
${ }^{47}$ Magnago (1995) esclarece dois pontos importantes a esse respeito. O primeiro deles é: baseado na noção de regiões funcionais, do ponto de vista dos polos de desenvolvimento, e de regiões homogêneas, do ponto de vista econômico-produtivo, o IBGE definiu a nova macrorregionalização brasileira para fins estatísticos (Norte, Nordeste, Centro-Oeste, Sul e Sudeste). O segundo diz respeito às quatro principais mudanças em relação à regionalização oficial anterior: (i) o conceito de região natural foi substituído pelo de região geográfica; (ii) além das cinco macrorregiões, o IBGE identificou microrregiões homogêneas, agrupadas por estado, criando níveis intermediários de amostragem e tabulação estatística; (iii) São Paulo passou a integrar a região Sudeste, ao invés da região Sul; (iv) Os estado da Bahia e Sergipe passaram a integrar a região Nordeste, como proposto pela Sudene em 1959.

${ }^{48}$ Segundo Becker \& Egler (2003), a crise econômica de 1973 afetou a capacidade de investimento do estado levando à adoção de políticas de desenvolvimento não mais macrorregionais e, sim, subregionais, traduzidas pelos polos de desenvolvimento. Enfatizam ainda que "poucos são os países do mundo que levaram tão longe as ideias de Perroux como o Brasil" (p.148).

${ }^{49}$ São Paulo, Belo Horizonte, Porto Alegre, Recife, Salvador, Curitiba, Belém e Fortaleza.
} 
reorganização do sistema urbano, a partir da distribuição dos recursos e atividades para as cidades médias, para incentivar a instalação de empresas nas grandes cidades, já favorecidas pelas condições que ofereciam à rápida acumulação de capital (ROCHEFORT, 1988).

A principal dificuldade de formulação da política era incorporar a compreensão de que "as concentrações urbanas refletiam uma concentração de renda" (SOUZA, 2004, p.117). Sob uma visão setorialista do urbano "entendida como a somatória da habitação, do transporte, do saneamento básico, da gestão administrativa, das finanças", as prioridades eram estabelecidas por setor e "não nos lugares numa perspectiva de promoção do desenvolvimento da totalidade do território urbano brasileiro" (SOUZA, 2004, p.114-118).

A gestão metropolitana foi marcada pela centralização, pelo autoritarismo e pela ausência de mecanismos de cooperação entre as esferas governamentais (SOUZA C., 2003). Além disso, havia um forte antagonismo entre as diretrizes da Política Nacional de Desenvolvimento Urbano (PNDU, 1974), de caráter descentralizador e desconcentrador, e as diretrizes do II PND de caráter centralizador e concentrador, já que os grandes investimentos deste plano estavam direcionados prioritariamente para a região Sudeste, a mais concentrada em termos urbanos e industriais (SOUZA, 2004).

A criação de polos de desenvolvimento industrial parecia ser o modelo mais adequado para organizar o território segundo as diretrizes do Estado autoritário, com a criação de locais sob a administração das superintendências regionais, privilegiados pelos recursos públicos e privados investidos nas especializações regionais (vantagens comparativas) e capazes de interligar os circuitos econômicos nacionais e internacionais (BECKER \& EGLER, 2003).

Os polos de desenvolvimento concentravam os investimentos públicos prioritários em especializações produtivas regionais (mineração, siderurgia, metalurgia, químico-petroquímica, cimento, celulose e papel, bens de capital, agricultura, energia, transportes e comunicação) para serem capazes de responder às demandas da indústria, da urbanização e da integração do território, numa fase de substituição de importações (PINTO, 2004). 
No início da década de 1980, a política regional foi substituída pela implantação de grandes projetos de exploração mineral, cujo marco é o Programa Grande Carajás, com o objetivo de manter o crescimento econômico através de investimentos das empresas estatais e atração de investimentos estrangeiros, bem como, aumentar as exportações e a internacionalização das empresas estatais (Becker \& EGLER, 2003).

A crise política e a recessão que se instalou no país, nos anos 80 , provocaram uma verdadeira desorganização da economia nacional ${ }^{50}$ (FIORI, 1990). O planejamento estatal do desenvolvimento foi substituído pelos planos de estabilização econômica, num período que vai de 1986, com o Plano Cruzado, até 1994, com o Plano Real; apesar da Constituição de 1988 trazer mudanças no modo de se fazer planejamento no Brasil, com o surgimento dos planos plurianuais (Brito, 2004). O Plano Plurianual (PPA) constituiu-se, juntamente com a Lei de Diretrizes Orçamentárias (LDO) e a Lei Orçamentária Anual (LOA), um arranjo programáticooperacional, definindo prazos, critérios e executores, não sendo "capaz, por si, de ocupar a contento o vazio da falta de reflexões e debates mais amplos sobre os rumos do desenvolvimento nacional" (GALVÃO \& BRANDÃO, 2003, p.190). Além disso, os autores ressaltam que, entre 1990 e 2002, os limites que o neoliberalismo e a globalização impuseram ao papel do Estado e à economia brasileira, reduziram o grau de liberdade da sociedade para definir os rumos do seu desenvolvimento; fato agravado pela não democratização do planejamento:

(...) evitou-se constituir uma sistemática que propiciasse a discussão aberta de seus pontos fundamentais e possibilitasse um engajamento adequado das várias forças sociais na discussão dos rumos e caminhos principais da sociedade brasileira. Dessa forma, o planejamento assumiu, na sociedade que se democratiza, traços que apresentava no seu momento

\footnotetext{
${ }^{50}$ Nas palavras de José Luis Fiori: “... a crise dos anos 80 maximizou e foi consequência, ao mesmo tempo, da contradição básica da estratégia desenvolvimentista da relação do Estado com o mercado, imposta pelo compromisso assumido, já na década de 30, entre as várias e heterogêneas frações do nosso empresariado. Este fator eminentemente político é que fez da nossa crise econômica uma crise de Estado, e de nossa transição democrática, um lento processo de implosão do próprio Estado desenvolvimentista, de tal forma que, ao longo dos anos 80 , as empresas privadas se ajustaram financeiramente, acumulando lucros, gerando poupança e reduzindo o seu endividamento, usufruindo, como contra-face perversa, do desajustamento progressivo que levou o setor público à falência e a autoridade político-econômico à mais completa paralisia, expropriada do último e decisivo instrumento: a política monetária." (FIORI, 1990, p.144).
} 
de maior visibilidade na ditadura (GALVÃO \& BRANDÃO, 2003, p.193).

A globalização neoliberal gerou uma intensa despolitização e uma privatização da política, conduzida por uma minoria, evidenciando uma crise do coletivo, do público (Estado) e da cidadania (HOBSBAWN, 2000). O discurso do desenvolvimento regional passou a ser utilizado para "a cessão de parcelas do território como instrumento de negociação direta com os capitais transnacionais" e a "dimensão social do planejamento, que passou ao largo de trinta anos de modernização conservadora", tornou-se o grande desafio da sociedade brasileira e a força de luta pela redemocratização do país e pela conquista da cidadania (BECKER \& EGLER, 2003, p.226-250).

Os Planos Nacionais de Desenvolvimento modernizaram o país no sentido de torná-lo urbano-industrial, criando um mercado interno crescente e integrado. Porém, não conseguiram diminuir as grandes desigualdades socioespaciais entre as regiões do Brasil, que seriam agravadas com agenda neoliberal e a difusão seletiva e concentrada do meio técnico-científico-informacional ${ }^{51}$ nas áreas mais dinâmicas economicamente do território.

A crise urbana resultou da modernização perversa do território, cuja maior expressão é a metrópole corporativa e fragmentada (SANTOS, 1990). A industrialização consolidada nas regiões e cidades mais ricas do Brasil, sobretudo nas capitais do Sul, Sudeste e Nordeste, era acompanhada por intenso processo de crescimento das grandes metrópoles e pelo agravamento das desigualdades socioespaciais, com expansão das periferias empobrecidas. A atuação do Estado na implantação dos modelos viários, habitacionais, sanitários, entre outros, foi fundamental para que o sentido dos usos do território também se tornasse a reprodução da pobreza. As políticas públicas, atraindo a modernidade, fizeram com que as metrópoles atraíssem também as esperanças dos pobres de outras regiões menos enriquecidas e modernizadas do Brasil. O intenso processo de migração interna, associado às políticas públicas voltadas aos interesses corporativos de uso do

\footnotetext{
${ }^{51}$ A partir da década de 1970, inicia-se o período técnico-científico-informacional, com a difusão de um sistema técnico planetário de grande conteúdo científico e informacional que permite a instalação, nas formações socioespaciais, de uma racionalidade financeira e corporativa de uso do território pelas grandes empresas internacionais (SANTOS, 1996).
} 
território - aqueles ligados ao capital monopolista e oligopolista -, agravou a crise urbana, a partir da década de 1970 (SANTOS, 1990).

Em meados da década de 1980, a regionalização começa a se aproximar das tentativas de redemocratização e descentralização do Estado. Este é o caso da criação de regiões de governo em São Paulo (decreto $n^{\circ}$ 22.592/1984), que tinham por objetivo a descentralização e a participação democrática no planejamento regional, mas, como alerta Silva Neto (2003, p.366), também eram uma forma de delegar a resolução de problemas estruturais às comunidades regionais, "detentoras do conhecimento empírico", porque conheciam melhor as realidades locais.

No final da década de 1980, o IBGE reformulou a regionalização oficial do Brasil, a partir de uma nova metodologia para a definição de meso e microrregiões, mantendo as macrorregiões estabelecidas na década de 1970. A noção de região homogênea produtiva, que havia embasado o estabelecimento das sub-regiões não conseguia mais explicar as mudanças espaciais, resultantes da complexa divisão territorial do trabalho e da inserção cada vez maior do Brasil no período da globalização. O IBGE reconheceu que o desenvolvimento econômico afetava de maneira diferenciada o território brasileiro, gerando um leque maior de situações de modernização, conforme as mudanças institucionais e os avanços socioeconômicos alcançados pelos lugares e regiões, nas últimas décadas (MAGNAGO, 1995).

De acordo com a autora, as condições físicas, o processo de metropolização e de industrialização continuaram sendo considerados como elementos estruturantes das diferenciações espaciais, entretanto, a metodologia de regionalização baseava-se na totalidade nacional para a identificação de meso e microrregiões, que passaram a ter a denominação de "geográficas". A mesorregião geográfica foi recortada no limite de uma Unidade da Federação e representava um processo social, um quadro natural e redes de comunicação e urbanas como elemento de articulação espacial. Já a microrregião, recortada no limite da macrorregião, representava uma especialidade produtiva (agropecuária, industrial, mineral e pesqueira), além de uma especificidade do quadro natural e das interações espaciais e socioeconômicas. A nova regionalização apresentava "um número maior tanto de unidades de menor área quando de espaços intermediários (MAGNAGO, 1995, p.86). 
No início da década de 1990, o Nordeste permanece como “questão regional", a Amazônia constitui-se a "grande fronteira" e o Centro-Oeste especializa-se como polo agroindustrial (BECKER \& EGLER, 2003). Contudo, o planejamento regional não foi prontamente retomado pelo Estado após a redemocratização, seja por conta da crise fiscal e da falta de capacidade técnica, política e econômica para implantar as reformas necessárias, seja pela adoção da agenda neoliberal, também restringida por essas questões, que configurou uma nova ordem política e econômica entre Estado e Mercado (SOLA, 1993).

No contexto da política neoliberal (Estado mínimo, regulador) e de redemocratização do Brasil, a questão regional foi substituída pela descentralização (municipalismo) e pela relação "global-local" (desenvolvimento local). O debate sobre desenvolvimento foi suprimido pela ideia de competitividade, inovação tecnológica, estabilidade macroeconômica, rentabilidade financeira e reforma gerencial do Estado. E a "crença exacerbada no jogo das forças de mercado levou à rejeição do planejamento" e da questão regional, que perdeu centralidade, com a emergência dos temas urbanos/locais (PIQUET \& RIBEIRO, 2008, p.50).

Na globalização, a região tornou-se um lócus privilegiado da competitividade das grandes empresas e da integração internacional dos países. As regiões passaram a se organizar como "vitrines para o mercado global" e novas ideologias embasaram sua definição (SILVA NETO, 2003, p.363).

$\mathrm{O}$ aumento das desigualdades socioespaciais se acelera em decorrência das modernizações e da internacionalização da economia brasileira, revelando grande concentração dos recursos, infraestrutura e fluxos no território (SANTOS \& SILVEIRA, 2001). Isso provoca uma maior competição entre os entes federados na luta por investimentos internos e externos, dificultando o estabelecimento de relações intergovernamentais mais cooperativas.

A corrida pela criação de municípios, nessa fase, mostrou que a fragmentação do território em novas fronteiras internas atendia, por um lado, às demandas de descentralização e, por outro, aos interesses corporativos de atuação de empresas no mercado mundial (CATAIA, 2001). Uma verdadeira "guerra entre os lugares" (SANTOS, 1996) se instalou na medida em que estes competiam pelos investimentos 
do mercado, em escala global, oferecendo, por exemplo, isenção fiscal às empresas, terrenos, equipamentos e infraestruturas urbanas e de circulação.

A nova fase de modernização priorizou as regiões mais competitivas, que se especializaram nos parâmetros produtivos internacionais de qualidade e custo, concentrando os investimentos públicos e privados (CASTILHO, 2008). Os investimentos públicos modernizaram infraestruturas que foram sendo transferidas para o comando privado, como as redes de telecomunicações, ampliando os usos corporativos dos lugares e regiões (TOZI, 2009). O Centro-Oeste e parte da Amazônia, tomados pela expansão dos fronts agrícolas, ilustram muito bem a tendência à maior especialização produtiva dos lugares e à ampliação das conexões com o mercado internacional, ao mesmo tempo em que esses processos reproduzem, nas cidades do agronegócio ${ }^{52}$, “as mesmas desigualdades inerentes às grandes metrópoles brasileiras" (FREDERICO, 2010, p.244).

Embasado pelo objetivo de maior aproximação com o capital internacional e da integração competitiva de áreas do território ao mercado global (MOURÃO, 1994; ARAÚJO, 2000), o Estado brasileiro concentrou os esforços políticos e financeiros nos Eixos Nacionais de Integração e Desenvolvimento (Enid) (Plano Plurianual 1996/1999; Plano Plurianual 2000/2003).

Segundo Galvão \& Brandão (2003), entre os apelos técnicos e políticos da estratégia dos Eixos, destacam-se: (i) a eleição de um novo presidente (Fernando Henrique Cardoso, do PSDB); (ii) a estabilidade econômica promovida pelo Plano Real, de 1994, gerando um ativo político; (iii) a retomada dos fluxos de investimento direto estrangeiro e financeirização da economia, alcançando importante soma de recursos; (iv) a continuidade das opções neoliberais na política brasileira; e (v) o "Custo Brasil" da infraestrutura, do mercado de trabalho e do sistema fiscal, para a inserção do país no mercado internacional.

As redes de transporte, comunicação e energia que viabilizavam a logística de integração dos centros mais dinâmicos com o mercado internacional, configuravam os grandes eixos de desenvolvimento e integração ${ }^{53}$. O objetivo central era aumentar

\footnotetext{
52 "A desigualdade, mais do que a modernidade, passa a ser o principal signo representativo das cidades do campo moderno" (FREDERICO, 2010, p.244).

53 A ideia dos eixos nacionais de integração e desenvolvimento foi embasada, sobretudo, pelo documento "Infra-Estrutura para o Desenvolvimento Sustentado e Integração da América Latina", de
} 
o potencial exportador dessas áreas, sobretudo de commodities minerais e agroindustriais, através de investimentos em infraestrutura para ampliar a fluidez territorial (aeroportos, portos, rodovias e ferrovias; telefonia fixa e móvel; hidrelétricas e termelétricas). Outros projetos complementares e difusos, de desenvolvimento social e informação e conhecimento, eram encarados apenas na medida em que favoreciam o objetivo central (GALVÃO \& BRANDÃO, 2003). Tratava-se de uma visão setorial e seletiva do território.

As novas regionalizações não se prendiam mais às áreas de influência de uma capital regional, mas, sim, na centralidade dos grandes sistemas de engenharia: redes logísticas de fluidez do território (SILVA NETO, 2003). A relação entre dinamismo econômico espacial e redes de transporte foi desenvolvida desde os primórdios das análises econômicas espaciais elaboradas por Von Thünen e Lösch, sendo atualizada ao longo do tempo; inclusive nos anos de 1970, no Brasil, os "corredores de transporte" foram utilizados no planejamento (GALVÃO \& BRANDÃO, 2003). Contudo, é possível identificar uma tentativa de relacionar os Eixos com alguns aspectos da teoria da polarização de Boudeville (ABLAS, 2003), pois os estudos dos Eixos apontam que "as atividades dominantes estariam localizadas em 'centros dinâmicos', apresentados como polos de infraestrutura econômica, responsáveis pelo dinamismo econômico do eixo" e cada eixo especializado desempenharia um papel na divisão territorial do trabalho (MANZONI NETO \& SILVA BERNARDES, 2008, p.66). Os Eixos seriam uma "vertebração logística" que dinamizaria uma área de influência contígua e complementar (ABLAS, 2003, p.173).

$\mathrm{Na}$ política territorial dos dois Governos de Fernando Henrique Cardoso, a integração competitiva se sobressaiu à integração interna, priorizando áreas economicamente mais dinâmicas e exportadoras, em detrimento daquelas com menor dinamismo, ampliando a competitividade das regiões já competitivas e concentrando

autoria de Eliezer Batista e equipe, quando ministro da Secretaria de Assuntos Estratégicos da Presidência da República (SAE), durante o Governo Itamar Franco. "Baseada numa visão de logística a partir da infra-estrutura de transportes - especialmente ferrovias, portos, navegação de longo curso e de cabotagem - e voltada especialmente para as commodities minerais e agroindustriais, a proposta defendia uma perspectiva de exploração de potencialidades nas duas metades - cinturões Sul e Norte - da América do Sul, sugerindo a realização de obras voltadas à conexão dos centros de produção do Continente aos mercados Globais." (GALVÃO \& BRANDÃO, 2003, p.194). Contudo, segundo os autores (p.200), três importantes propostas da concepção original foram cortadas no projeto dos Eixos: "a articulação costeira via navegação de cabotagem, as articulações com o Pacífico e a integração latino-americana”. 
investimentos no Sul-Sudeste, fronteira Noroeste e pontos dinâmicos do Nordeste e Norte (ARAÚJO, 2000). Os Eixos aprofundavam ainda mais estas estratégias de cunho estritamente econômico, investindo em grandes obras de infraestrutura (transporte, energia e comunicação), acentuando a especialização produtiva de determinadas regiões. O estudo dos Eixos ressaltava ainda o papel regulador do Estado na condução dos investimentos, atraentes para a iniciativa privada, seguindo as orientações neoliberais.

Segundo Araújo (2000), a abordagem dos Eixos restringia a compreensão da complexidade regional brasileira e os objetivos da política, pois o Estado não cumpria sua missão de contrabalançar as desigualdades regionais, com investimentos em áreas menos dinâmicas ("não competitivas"), pelo contrário, acentuava ainda mais a concentração de recursos públicos e privados nas áreas já concentradas, reforçando a lógica do mercado e as desigualdades socioespaciais.

Para Galvão \& Brandão (2003), apesar de todas as críticas que se possa fazer aos Eixos, a proposta representou a retomada do planejamento territorial no Brasil. Ressalta-se, entretanto, que a elaboração dos estudos e dos planos de investimento e modernização dos Eixos ficou a cargo de um consórcio internacional de empresas de consultoria (Consórcio Brasiliana ${ }^{54}$ ), deixando claro o papel do Estado como regulador e não planejador, interventor. O planejamento territorial conduzido por agentes da globalização (MANZONI NETO \& SILVA BERNARDES, 2008) é um dos fatos que distingue essa fase das anteriores e da fase posterior (a partir dos anos 2000), quando o Estado atua como planejador e utiliza, para isso, as teses produzidas nacionalmente.

Durante a década de 1990, a produção e o controle das informações sobre o território brasileiro, indispensáveis ao exercício da soberania e da proposição de projetos de desenvolvimento, foram sendo apropriados por empresas transnacionais

\footnotetext{
${ }^{54}$ Constituído em 1997, o Consórcio Brasiliana era liderado pela empresa Booz Allen \& Hamilton, incluindo a Bechtel International e o ABN Amro Bank. A Booz-Allen também participou ativamente do Programa Nacional de Desnacionalização (PND) (MANZONI NETO \& SILVA BERNARDES, 2008). Segundos os autores, nessa época, essas empresas estavam entre as principais firmas de consultoria do mundo, atuando em diversos países junto às corporações privadas e aos governos. Publicações citadas por Galvão \& Brandão (2003):

Consórcio Brasiliana. (Booz Allen, Bechtel \& ABN Amro). Relatório preliminar do marco inicial do serviço e visão estratégica 2020. Brasília: BNDES e Ministério do Orçamento e Gestão, 1998. . Identificação de oportunidades de investimentos públicos e/ou privados (Estudo dos Eixos). Brasília: BNDES e Ministério do Orçamento e Gestão, 2000, v.3.
} 
de consultoria que atuaram junto ao BNDES no Programa Nacional de Desestatização (PND) e na proposição do PPA e das políticas territoriais (FARIAS \& SILVA BERNARDES, 2008). Segundo os autores, as empresas adquiriram uma posição central no planejamento e assumiram funções estratégicas no Estado brasileiro, ao controlarem informações sobre o território e assessorarem a burocracia estatal, reforçando as diretrizes neoliberais na política do país.

Diante do quadro exposto, ponderamos que as concepções de planejamento territorial em curso se afastam de uma visão integrada do território usado. Tende-se a adotar, hoje, para o planejamento das cidades e regiões, as bases teóricas da Business Administration, aplicando ao planejamento do território tudo aquilo que é aplicado ao planejamento de uma empresa. Elabora-se para o território uma lista de ameaças, oportunidades, obstáculos, que corresponde basicamente aos mesmos estabelecidos para uma empresa. Nesse processo, as empresas de consultoria, sobretudo transnacionais, adquirem uma força inequívoca, pois aparecem como agentes indispensáveis para a sistematização de informações sobre as virtualidades dos lugares. (MANZONI NETO \& SILVA BERNARDES, 2008, p.70).

A atuação do Estado através da política dos Eixos aprofundou as disputas entre estados e municípios para se tornarem economicamente dinâmicos (ARAÚJO, 2000), acentuando a "guerra entre os lugares", os usos corporativos e a fragmentação do território em espaços nacionais da economia internacional (SANTOS, 1996). Com a maior inserção de certas regiões na divisão internacional do trabalho, competindo com outras regiões no mundo por investimentos privados, o território ficou "mais vulnerável às decisões externas" (FREDERICO, 2010, p.245).

Os processos históricos de modernização incompleta e seletiva do território brasileiro resultaram em desigualdades regionais, marcadas por situações de concentração e escassez de recursos técnicos, científicos, informacionais e financeiros (SANTOS \& SILVEIRA, 2001). O Brasil adentrou o século XXI caracterizado por situações que distinguem quatro grandes regiões geográficas: Amazônia, Nordeste, Centro-Oeste e Região Concentrada; na qual a Região Concentrada, formada pelos estados do Sul e Sudeste, se caracterizaria pela concretização mais densa e contínua do meio técnico-científico-informacional, em comparação às outras regiões; a Região Centro-Oeste surgiria como um novo front de ocupação, fundamentado na rápida e crescente difusão das variáveis do período voltadas para os usos da agricultura e da urbanização globalizadas; a Região 
Nordeste seria caracterizada por uma ocupação antiga e uma difusão mais pontual (manchas) e pouco densa do meio técnico-científico-informacional; e a Amazônia representaria a difusão mais pontual e menos densa do meio técnico-científicoinformacional, sendo caracterizada pela rarefação e descontinuidade demográfica e técnica (SANTOS \& SILVEIRA, 2001).

No início dos anos 2000, o esgotamento das políticas neoliberais, a crise financeira global, a estagnação do crescimento econômico dos países centrais e o aumento das desigualdades socioespaciais propiciaram a retomada do debate sobre o papel do Estado e novas estratégias de desenvolvimento no Brasil. Os países emergentes tomaram a dianteira nessa discussão (EVANS, 2012).

Durante os Governos de Luis Inácio Lula da Silva (2003-2010), do Partido dos Trabalhadores - PT, o Estado brasileiro investiu na construção de um projeto nacional de desenvolvimento, tendo como objetivo central o crescimento econômico e a redução das desigualdades sociais e regionais. O Estado recuperou sua liderança no processo de desenvolvimento, procurando fortalecer a cooperação intergovernamental e a participação social no planejamento.

Essa nova fase denominada de neodesenvolvimentista se distingue da fase nacional-desenvolvimentista ${ }^{55}$, dentre outros fatores, pela prioridade dada à redução da pobreza e das desigualdades (ERBER, 2011). Anteriormente, o Estado havia priorizado a industrialização, o mercado interno e as classes de média e alta renda; a grande novidade do momento presente foi priorizar as camadas de renda mais baixa, incentivando o dinamismo econômico a partir do potencial de consumo da maioria da população brasileira, e duas variáveis foram muito importantes nesse sentido: as políticas de distribuição direta de renda e o aumento do crédito (ARAÚJO, 2012).

Dentre os principais pontos da nova agenda, destacam-se: (i) a ampliação do mercado interno, com o fortalecimento do parque produtivo nacional, incluindo

\footnotetext{
55 “A obra intelectual e executiva de [Celso] Furtado nos anos 50 e início dos 60 já continha uma forte preocupação com os problemas sociais e inclinava-se crescentemente para a defesa de reformas. Refletia, porém, o pensamento de um intelectual que acreditava que o processo de industrialização constituísse a grande solução para os problemas sociais básicos e, além disso, de um servidor público que tinha uma carreira aberta à ascensão política no interior do Estado - entidade indispensável, segundo o projeto de sua corrente, para que se realizasse a industrialização. Predominou, por essa razão, em seu pensamento, como no dos demais desenvolvimentistas nacionalistas, a defesa de medidas de política econômica relativas ao desenvolvimento industrial." (BIELSCHOWSKY, 2000, p.154)
} 
incentivos à inovação, e o aumento do consumo das famílias, auxiliado por programas de transferência direta de renda e pelo aumento do crédito e do emprego; (ii) fortalecimento da democracia e da participação social nos debates sobre o desenvolvimento; (iii) aumento dos investimentos em infraestrutura, habitação, inovação e na produção, através de incentivos governamentais e parcerias públicoprivadas; e (v) diminuição das desigualdades sociais e regionais, com a elaboração do planejamento regional através da cooperação intergovernamental e da participação da sociedade.

$\mathrm{O}$ neodesenvolvimentismo tem como instrumentos o Plano Plurianual de 2003-2007, a Política Industrial, Tecnológica e de Comércio Exterior (Pitce), a Política Nacional de Desenvolvimento Regional (PNDR) e o incentivo às relações público-privadas. Sendo reforçado no segundo Governo Lula, com os instrumentos: Plano de Aceleração do Crescimento (PAC 2007-2010) e a Política de Desenvolvimento Produtivo (PDP).

A partir de 2003, com a retomada do papel do Estado no planejamento do desenvolvimento, a questão regional é revisitada, com a incorporação de novos temas (MIN, 2005; PIQUET \& RIBEIRO, 2008). E a estratégia da regionalização volta como um instrumento poderoso de reconhecimento das forças políticas e sociais que podem ser mobilizadas nas regiões em função do novo projeto de desenvolvimento. Isto sem perder de vista que as regiões compreendem necessariamente fluxos, poderes e projetos cujas intencionalidades e capacidade de comando ultrapassam os limites regionais e as fronteiras nacionais.

O avanço das políticas de desenvolvimento regional passa a depender da priorização dos aspectos políticos, mais do que dos aspectos econômicos, além da renovação das ideias, da compreensão da realidade e de uma visão integrada do território brasileiro, atualizando os motores de reprodução da riqueza e da pobreza, não sendo possível pensar uma região sem pensar o Brasil (FURTADO, 2003). O autor ressalta ainda que "o projeto de desenvolvimento do Brasil é feito a partir das potencialidades do mercado interno" e de mudanças estruturais que permitam melhorar a distribuição de renda, devendo tratar de problemas nacionais, considerando que "nossos desafios são de natureza política e não propriamente econômica". 
Entre 2003 e 2006, foram realizados estudos e seminários para embasar as novas políticas nacionais de ordenamento territorial ${ }^{56}$ e de desenvolvimento regional, contando com as contribuições de geógrafos, economistas e trabalhadores do setor governamental brasileiro (MIN, 2005; BRASIL, MI, 2006). Foram elencados os desafios políticos e metodológicos a serem enfrentados, considerando os objetivos da nova agenda de desenvolvimento e a complexidade da realidade brasileira.

Dentre os desafios políticos, destaca-se a necessidade de associar o planejamento regional aos processos de descentralização política, à participação social (RÜCKERT, 2005, MORAES, 2005) e às desigualdades das relações de poder, não apenas entre os governos, mas no âmbito de toda a sociedade (HAESBAERT, 2005). O planejamento territorial deve "exprimir um pacto territorial" coordenado pela União e baseado na cooperação e parceria entre os níveis de governo, considerando também as relações bilaterais e multilaterais com os países vizinhos (MORAES, 2005). Entretanto, o funcionamento do sistema federativo brasileiro que, desde a Constituição Federal de 1988, vem experimentando a revalorização do papel dos estados e o exercício da autonomia dos municípios tornou mais complexa a relação intergovernamental (COSTA, 2005), sobretudo num contexto de grande desigualdade regional. As bases de articulação política deveriam resultar em novos arranjos institucionais de gestão nas regiões (SANTOS T., 2005). Outro desafio recai sobre a tentativa de integração regional das políticas públicas, que tendem à fragmentação em decorrência da "crescente especialização dos aparelhos do Estado e à setorização dos planos, programas e projetos", além de terem que responder às "demandas frequentemente conflitantes, geradas pelos novos e poderosos fluxos internacionais e nacionais (de capitais, bens, serviços e informações)", reduzindo a eficácia das macropolíticas (COSTA, 2005, P.55-56).

Dentre os desafios metodológicos e conceituais, destaca-se a tentativa de renovação do conceito de região em relação à teoria dos polos de desenvolvimento, predominante nas décadas de 1950-80, e à "geografia dos fluxos ou das redes", característica do período da globalização (HAESBAERT, 2005; COSTA, 2005; BECKER, 2005; BRASIL, MIN, 2006). Sendo imperativo um olhar estratégico da

\footnotetext{
56 O termo "Ordenação do Território" está fixado legalmente através do artigo 21, inciso IX da
} Constituição Federal de 1988. 
União sobre a sociedade e o território brasileiro contemporâneos, distinguindo as escalas e direcionalidades dos vetores hegemônicos da globalização, que aceleram as diferenciações espaciais internas e resultam em usos divergentes, desiguais, competitivos e conflituosos (COSTA, 2005). Para articular as políticas setoriais e induzir as políticas estaduais e municipais, seria necessária a construção de uma visão geoestratégica a partir de uma abordagem da integralidade e da contiguidade do território nacional e da produção de um diagnóstico geográfico, para indicar tendências, demandas e potencialidades regionais (MORAES, 2005). Haveria necessidade de análise da capacidade do Estado de efetivo poder de indução da inserção de todas as regiões no processo de distribuição da riqueza e modernização do território (RÜCKERT, 2005), considerando-se a complexidade para ordenar o território quando as organizações em redes transcendem as fronteiras nacionais (BECKER, 2005).

O planejamento regional deveria, por um lado, criar uma nova metodologia para atualizar os dados e análises sobre as desigualdades socioespaciais e definir regionalizações segundo as diferentes escalas de ação, e, por outro, criar uma nova estratégia política para compatibilizar as ações setoriais nos lugares, definir as responsabilidades dos entes e coordenar as políticas, desde o nível federal (COSTA, 2005; BECKER, 2005).

A "questão regional" foi retomada como resultado dos diferentes contornos que as relações políticas e econômicas foram adquirindo ao longo do tempo (BRASIL, 2010a). O desenvolvimento regional foi definido como um "conjunto de ações para promover processos socioeconômicos em áreas definidas do território, com uma visão integradora e sustentável ${ }^{57}$, que induzam ao bem estar social e à redução de desigualdades regionais" (BRASIL, MIN, 2006, p.16).

Três pontos foram destacados na elaboração do novo planejamento (BRASIL, MIN, 2006). Primeiro, a logística, pensada como um serviço de alto valor agregado que reduz o custo e agiliza a circulação, com investimentos visando a competitividade das regiões, a integração com a América do Sul e a interiorização do sistema de logística no território, ampliando o acesso dos produtores nacionais e dos

\footnotetext{
57 A influência das ideias de "desenvolvimento sustentável" no planejamento regional incide tanto
} sobre o uso dos recursos naturais, quanto sobre os conflitos sociais daí decorrentes. 
consumidores às redes, aumentando o valor agregado da produção e o consumo interno, isto é, pensar no mercado interno também a partir de uma "logística do pequeno" (p.107). Segundo, as cidades como elemento-chave da estruturação da divisão territorial do trabalho, concentrando os nós das redes e as possibilidades de geração de emprego e renda, e as múltiplas escalas que devem servir como referência para se repensar o planejamento e o acesso aos serviços públicos, a exemplo da regionalização do Sistema Único de Saúde. Terceiro, as formas de conjugar ações do Estado com ações do mercado e da sociedade civil, para a implantação e administração dos processos de decisão das políticas territoriais, observando as principais experiências internacionais ${ }^{58}$ e considerando a coexistência de diferentes formas de organização socioeconômica e a multidimensionalidade da interação entre diversos atores e circuitos em diferentes níveis (regional, nacional, internacional), que condicionam os acordos regionais.

O Governo Lula herdou algumas propostas de políticas regionais do governo anterior, tais como os Eixos Nacionais de Integração e Desenvolvimento ${ }^{59}$, as Regiões Integradas de Desenvolvimento Econômico (Ride) ${ }^{60}$, os Arranjos Produtivos Locais (APLs) ${ }^{61}$ e o Zoneamento Econômico Ecológico (ZEE) ${ }^{62}$, atualizando-as e modificando-as conforme os novos objetivos da nova política.

\footnotetext{
${ }^{58}$ Nafta - North America Free Trade Agreement (com destaque para as experiências do México e Canadá), e União Europeia (com destaque para as experiências da França e Itália). Neste caso, com foco no sistema de governança territorial (legislação e arranjos institucionais) e no planejamento continuado (política de governo e instrumento de governabilidade) (BRASIL, MIN, 2006).

59 Além disso, como aponta o documento da Política Nacional de Ordenamento Territorial (BRASIL, 2006, p.131): “O PPA 2004-2007, já no governo Lula, também conhecido por "Brasil de Todos”, teve como modelo a gestão orientada para resultados e como premissa a disponibilidade de informações gerenciais, em tempo real, para todos os gestores envolvidos com a implementação dos programas. Esse novo PPA atualizou os eixos nacionais de desenvolvimento - trabalho desenvolvido por firmas contratadas para atualizar o portfólio de oportunidades de investimentos - e contou com uma nova proposição de investimento público-privado".

${ }^{60}$ As Regiões Integradas de Desenvolvimento foram instituídas pela Lei Complementar $\mathrm{n}^{\mathrm{a}}$ 94/1998, com o objetivo de planejar áreas metropolitanas que ultrapassam os limites de um estado, tendo como base os complexos geoeconômicos (Art. 43 da CF, 1988).

${ }^{61}$ Segundo o Ministério do Desenvolvimento, Indústria e Comércio Exterior, os Arranjos Produtivos Locais tiveram grande difusão no país a partir da década de 1990 e foram incorporados no PPA desde 2000. O MDIC traz a seguinte definição: "Arranjos Produtivos Locais são aglomerações de empresas, localizadas em um mesmo território, que apresentam especialização produtiva e mantêm vínculos de articulação, interação, cooperação e aprendizagem entre si e com outros atores locais, tais como: governo, associações empresariais, instituições de crédito, ensino e pesquisa" (http://www.desenvolvimento.gov.br).

62 O Zoneamento Econômico-Ecológico (ZEE) (CF, artigo n ${ }^{\circ} 165$, parágrafo primeiro), constante no PPA 2000-2003, também teve continuidade no Governo Lula (PPA 2004-2007).
} 
A Política Nacional de Desenvolvimento Regional (PNDR), lançada em 2007, tem como objetivo principal a redução das desigualdades sociais e regionais e suas estratégias devem ser convergentes com os objetivos de inclusão social, de produtividade, sustentabilidade ambiental e competitividade econômica (Decreto $\mathrm{n}^{\mathrm{o}}$ 6.047/2007; BRASIL, MIN, 2007). O financiamento ${ }^{63}$ dos projetos públicos e privados advém dos fundos constitucionais existentes nas áreas selecionadas, de recursos orçamentários do governo, do BNDES e do Banco do Brasil.

A PNDR utiliza os recortes regionais elaborados pelo IBGE, com base nas dinâmicas socioeconômicas e espaciais (conforme analisado anteriormente neste item): as macrorregiões definidas em 1969; as meso e microrregiões definidas em 1989 (BRASIL, 1990). O uso desses recortes facilitou a definição de diferentes escalas de ação e o uso dos dados censitários, utilizados para caracterizar o grau de dinamismo econômico e de desenvolvimento social das regiões. As microrregiões serviram como referência de análise estatística dos dados dos Censos, para o estabelecimento de um quadro referencial das desigualdades regionais, construído com base em indicadores econômicos, ainda que outros indicadores tenham sido utilizados de forma complementar ${ }^{64}$.

A metodologia priorizou duas variáveis (Decreto 6.074/2007, Anexo II): (i) Rendimento Médio Mensal por Habitante, englobando todas as fontes declaradas (salários, benefícios, pensões, etc); e (ii) Taxa Geométrica de Variação dos Produtos Internos Brutos Municipais por habitante. A classificação das microrregiões segundo o cruzamento dessas duas variáveis econômicas resultou em quatro grandes categorias sub-regionais:

\footnotetext{
${ }^{63}$ Fundo de Desenvolvimento da Amazônia - FDA; Fundo de Desenvolvimento do Nordeste - FDNE; Fundo Nacional do Meio Ambiente - FNMA; Fundos Constitucionais de Financiamento - FCO, FNE, FNO; Fundo de Amparo ao Trabalhador - FAT; Fundo Nacional de Assistência Social - FNAS; fundos de pensões, incentivos fiscais de IR e outras fontes, que atendam ao financiamento público e privado de investimento no território nacional, além de acordos de empréstimo com bancos e doações de organismos internacionais (BRASIL, MIN, 2006, p.149). Os Fundos Constitucionais de Financiamento (FCO, FNE e FNO) foram instituídos pelo ar.t 159, inciso I, alínea "c", da Constituição Federal e regulamentados pela Lei $n^{\circ} 7.827$, de 27/09/1989 e pela Lei $n^{\circ} 10.177$, de $12 / 01 / 2001$.

64 "Das variáveis reconhecidas como determinantes e/ou condicionantes das desigualdades regionais, algumas eram relacionadas à estrutura da ocupação das regiões (densidade demográfica, crescimento populacional e grau de urbanização). Outras diziam respeito à escolaridade da população em idade de trabalho (percentuais da população com menos de quatro anos e com mais de doze anos de estudo)." (LEITE, 2011, p.04).
} 
- Alta Renda - microrregiões com alto rendimento domiciliar, independente do dinamismo econômico observado;

- Estagnadas - microrregiões com médio rendimento domiciliar e médio ou baixo dinamismo econômico;

- Dinâmicas - microrregiões com baixo ou médio rendimento domiciliar e alto dinamismo econômico;

- Baixa Renda - microrregiões com baixo rendimento domiciliar e baixo dinamismo econômico.

Posteriormente, essa metodologia foi atualizada, com a aplicação do índice de cesta básica (valores Dieese), para obter a paridade do poder de compra, e com a adoção da escala municipal para cinco estado da região Norte (Acre, Amapá, Amazonas, Pará e Roraima), devido às grandes dimensões dos territórios municipais, acima da média brasileira, a fim de evitar distorções no mapeamento da tipologia (LEITE, 2011).

A PNDR elegeu como prioridade as microrregiões de baixa renda, dinâmicas e estagnadas para servirem de objeto de ação dos programas de redução das desigualdades regionais e integração das políticas públicas.

A partir dessa classificação, o Ministério da Integração Nacional definiu os limites territoriais das Mesorregiões Diferenciadas, compreendidas como regiões que recortam um ou mais estados e compartilham elementos integradores (dimensões econômica, físicoambiental, sociocultural e político-institucional), e que devem ser priorizadas na busca da redução das desigualdades a partir da potencialização da organização social e das especializações econômicas (BRASIL, MIN, 2009). Outras áreas de tratamento prioritário e estratégico na PNDR são o Semiárido, a Faixa de Fronteira e as Regiões Integradas de Desenvolvimento - RIDE's.

No que se refere às macrorregiões, entre 2007 e 2009, foram recriadas ${ }^{65}$ as Superintendências de Desenvolvimento do Nordeste - Sudene (LCP 125/2007), da Amazônia - Sudam (LCP 124/2007) e do Centro-Oeste - Sudeco (LCP 129/2009), aproveitando os Fundos Constitucionais de Desenvolvimento Regional.

65 A Medida Provisória no 2.146-1, de 04 de maio de 2001, que extinguiu as Superintendências de Desenvolvimento do Nordeste (SUDENE) e da Amazônia (SUDAM), criou as Agências de Desenvolvimento do Nordeste (ADENE) e da Amazônia (ADA) e os Fundos de Desenvolvimento do Nordeste - FDNE e da Amazônia - FDA. 
Os Territórios da Cidadania ${ }^{66}$ também constituem um recorte regional prioritário no planejamento do desenvolvimento, entretanto, estão sob o comando do Ministério do Desenvolvimento Social e Combate à Fome (MDS).

A proposta de renovação da Política Nacional de Desenvolvimento Regional (BRASIL, MIN, 2010; LEITE, 2011; BRASIL, MIN, 2012) está em fase de discussão. Dentre os principais objetivos, estão: ascender de Política de Governo à categoria de Política de Estado; abarcar todo o território nacional, incluindo programas destinados às regiões de "Alta Renda"; atualizar a tipologia regional com dados do Censo de 2010 e adotar uma nova nomenclatura regional ${ }^{67}$, "mais apropriada ao tipo de ação a ser empreendida pela política"; criar o Fundo Nacional de Desenvolvimento Regional, o Sistema Nacional de Informação para o Desenvolvimento Regional e, finalmente, o Sistema Nacional de Desenvolvimento Regional e Integração Territorial, como superestrutura institucional, construindo, assim um novo modelo de gestão regional (BRASIL, MIN, 2010; LEITE, 2011, P.13).

As discussões e os estudos que subsidiaram a nova Política Nacional De Desenvolvimento Regional evidenciam a dificuldade de se atualizar o conceito de

66 "O Governo Federal lançou, em 2008, o Programa Territórios da Cidadania, que tem como objetivos promover o desenvolvimento econômico e universalizar programas básicos de cidadania por meio de uma estratégia de desenvolvimento territorial sustentável. A participação social e a integração de ações entre Governo Federal, estados e municípios são fundamentais para a construção dessa estratégia" (http://www.territoriosdacidadania.gov.br).

${ }^{67}$ Grupo 1 - G1: Territórios com padrão consolidado de competitividade - reúne microrregiões (MRGs) de alta renda, independente do dinamismo observado. São regiões que dispõem de recursos suficientes para reverter situações de desigualdades encontradas em partes restritas de seus territórios e que se caracterizam por forte uso do potencial produtivo.

Grupo 2 - G2: Territórios em processo de incorporação econômica à dinâmica nacional - reúne MRGs com dinamismo crescente, acelerado ou emergente nos últimos anos, ainda que com padrões médios ou baixos de rendimento mensal médio por habitante. Grupo caracterizado por regiões que experimentaram transformações recentes na estrutura produtiva, em especial na agricultura.

Grupo 3 - G3: Territórios com padrão prolongado de estagnação - reúne MRGs que experimentaram um processo contínuo de estagnação econômica, em geral com potencial produtivo ocioso, acompanhados de reduções mais ou menos intensas de dinamismo, e com médio rendimento mensal da renda. Geralmente se caracterizam por territórios que possuíram dinamismo vigoroso em períodos passados.

Grupo 4 - G4: Territórios com fragilidade econômica - reúne MRGs que apresentam características de baixo rendimento e baixo dinamismo econômico. São espaços geográficos tradicionalmente excluídos da dinâmica social e econômica brasileira e que representam desafio extraordinário à PNDR. São territórios, portanto, para os quais convergem, prioritariamente, ações e atividades próprias da política regional, em estreita articulação com estratégias das políticas sociais. Apresentam situações de pobreza, déficit de cidadania e debilidade da base econômica, e estão concentrados sobretudo nas Regiões Norte e Nordeste do país. (LEITE, 2011, p.12-13). 
região de planejamento no contexto de transição do neoliberalismo para o neodesenvolvimentismo. Verifica-se uma combinação de regiões geográficas, definidas pelo IBGE no final da década de 1990, com regiões econômicas, definidas e atualizadas pela tipologia da PNDR. Por fim, se sobressai o aspecto político da regionalização, com a elaboração de planos e programas específicos para cada região (Regiões-Programa - RPs) (BRASIL, MIN, 2012b).

Conforme o termo usado pelo Ministério da Integração Nacional, a Política Nacional de Desenvolvimento Regional baseia-se em Regiões-Programa $(R P s)^{68}$, definidas segundo as escalas e os objetivos de ação política (BRASIL, MIN, 2012a).

A avaliação dos resultados da PNDR apontou como desafios o financiamento da política, a sua institucionalização em todos os níveis de governo, a ampliação do controle e da participação popular, a integração territorial das políticas setoriais e os impactos na redução das desigualdades regionais (LEITE, 2011; BRASIL, MI, 2012B; ROCHA NETO, 2012).

A proposta de criação do Fundo Nacional de Desenvolvimento Regional (FNDR), para ampliar os investimentos públicos, ainda está sendo discutida no âmbito da reforma tributária, no Congresso Nacional. O financiamento se concentrou nas macrorregiões Norte, Nordeste e Centro-Oeste, por conta dos fundos constitucionais, e os recursos orçamentários disponíveis foram limitados, com destaque para a elevada participação das emendas parlamentares (BRASIL, MIN, 2012b).

A PNDR conseguiu disseminar a temática regional no nível estadual, ainda que de maneira heterogênea, a exemplo dos programas regionais estaduais e criação de organismos específicos para o planejamento regional (LEITE, 2011). Entretanto, a PNDR "pouco dialoga com outras políticas setoriais”, que são construídas e operadas segundo lógicas e trajetórias próprias, condicionadas pelos grupos de interesse, políticas partidárias e pelo espaço que ocupam na agenda de governo (ROCHA

\footnotetext{
${ }^{68}$ Planos Macrorregionais de Desenvolvimento: para Amazônia (PAS), para o Nordeste (PNDE) e para o Centro-Oeste (PDCO). Planos sub-regionais: Plano do Semi-Árido (PDSA); Plano BR-163 Sustentável e Planos Mesorregionais de Desenvolvimento. Programas sub-regionais: Programa da Sustentabilidade de Espaços Sub-Regionais - Promeso; Promoção e Inserção Econômica de SubRegiões - Promover; Desenvolvimento Integrado e Sustentável do Semi-Árido - Conviver; Desenvolvimento Social da Faixa de Fronteira; Desenvolvimento da Região Integrada do Distrito Federal - Ride; e Organização Produtiva de Comunidades Pobres - Produzir.
} 
NETO, 2012, p.125). Essa questão expõe uma fragilidade da Política Nacional de Ordenamento Territorial que é a falta de um "sistema nacional integrado com capacidade de hierarquizar e possibilitar uma ação coordenada dos diferentes níveis de governo nos territórios", resultando numa diversidade de planos, projetos, leis e instrumentos de intervenção da União, Estados e Municípios, "frequentemente elaborados de forma conflitante e sem diálogos ou interlocuções" (PERES \& CHIQUITO, 2012, p.79).

No PNDR, as instituições que dialogam a partir de cada programa regional muitas vezes competem em relação às orientações programáticas e pelo próprio protagonismo do desenvolvimento regional, ao mesmo tempo em que as instâncias colegiadas do planejamento regional são esvaziadas de poder decisório (ROCHA NETO, 2012). Essa competição desde o nível federal até o regional dificulta a integração das políticas. A PNDR também não previu espaços de controle social e participação popular no desenvolvimento regional, cuja discussão fica restrita aos órgãos de governo, limitando seu potencial de democratização do planejamento (ROCHA NETO, 2012). Segundo a avaliação do Ministério da Integração, "faltou base política e consenso federativo" para possibilitar a coordenação das políticas setoriais no território, com baixa articulação dos programas com as políticas estaduais e limitada integração dos demais programas federais; por isso foi adotada a estratégia de realização das conferências nacional, macrorregional, estadual e mesorregional de desenvolvimento regional, abertas também à participação popular a partir de 2012 (BRASIL, MIN, 2012).

A análise dos dados do Censo de 2010, segundo a tipologia da PNDR de dinamismo das microrregiões, mostrou uma "leve tendência quanto à redução das disparidades regionais, mas em ritmo modesto" (LEITE, 2011, p.08). A PNDR resultou, em geral, em "ações pontuais, difusas e sem continuidade, com baixa capacidade de transformar a dinâmica regional" (BRASIL, MI, 2012b). Leite (2011) ressalta a interiorização do crescimento econômico, a consolidação das regiões produtoras de commodities agrícolas e minerais e a pequena reversão do processo de estagnação econômica em regiões de todo o país.

Independentemente dos resultados da PNDR, Araújo (2012) atenta para o maior crescimento do PIB, da taxa de emprego formal, das taxas de crédito e do 
consumo nas regiões Norte e Nordeste, expressando um maior impacto relativo das regiões mais pobres no dinamismo do crescimento brasileiro na primeira década dos anos 2000. A autora aponta que os investimentos do Plano de Aceleração do Crescimento (PAC) representaram grande peso nas regiões mais pobres. Destaca, ainda, que a região Nordeste concentra a pobreza extrema e também o ritmo mais acelerado de redução da pobreza, em relação às outras regiões.

O Quadro 2, a seguir, sintetiza as transformações ocorridas em relação à estratégia de planejamento regional no Brasil, desde a década de 1930 até 2011, segundo as mudanças nas agendas de desenvolvimento do país, no papel do Estado e nos conceitos e objetivos do planejamento. 
Quadro 2 - Planejamento regional no Brasil no contexto das diferentes agendas de desenvolvimento (1930-2011): papel do Estado, conceitos e objetivos.

\begin{tabular}{|c|c|c|c|c|}
\hline & $\begin{array}{c}\text { Progresso nacional }^{69} \\
(1930-50)\end{array}$ & $\begin{array}{c}\text { Nacional-desenvolvimentismo } \\
(1950-80)\end{array}$ & $\begin{array}{c}\text { Neoliberalismo } \\
(1980-2000)\end{array}$ & $\begin{array}{c}\text { Neodesenvolvimentismo } \\
(2000-2011)\end{array}$ \\
\hline $\begin{array}{l}\text { Papel do } \\
\text { Estado }\end{array}$ & $\begin{array}{l}\text { Construção da ideia de nação. } \\
\text { Consciência intervencionista, } \\
\text { assumindo papel direto na } \\
\text { acumulação capitalista, como } \\
\text { regulador, planejador e empresário. } \\
\text { Estruturação da burocracia estatal. } \\
\text { Investimentos públicos na indústria } \\
\text { de base visando menor dependência } \\
\text { do mercado externo. Segurança } \\
\text { nacional. Maior penetração e } \\
\text { controle da sociedade e do } \\
\text { território. }\end{array}$ & $\begin{array}{l}\text { Construção da ideia de } \\
\text { desenvolvimento nacional e das } \\
\text { alianças entre capital estatal, nacional e } \\
\text { estrangeiro. Planejador, financiador, } \\
\text { regulador, acionista e investidor. } \\
\text { Crescimento dos projetos estatais em } \\
\text { atividades estratégicas para a } \\
\text { industrialização, visando menor } \\
\text { dependência do mercado externo. } \\
\text { Expansão da participação na economia. }\end{array}$ & $\begin{array}{l}\text { Construção da ideia de } \\
\text { modernização a partir da } \\
\text { inserção do país na } \\
\text { globalização. Alianças com o } \\
\text { capital estrangeiro. Mínima } \\
\text { intervenção, papel regulador. } \\
\text { Abertura do mercado interno } \\
\text { e adequação do país às } \\
\text { demandas externas de } \\
\text { investimento. Incentivo às } \\
\text { exportações. }\end{array}$ & $\begin{array}{l}\text { Construção da ideia de desenvolvimento } \\
\text { associado ao combate à desigualdade social e de } \\
\text { renda. Alianças com o capital nacional e } \\
\text { estrangeiro, com foco na expansão do capital } \\
\text { nacional (pequenas, médias e grandes empresas). } \\
\text { Planejador, financiador, regulador, acionista e } \\
\text { investidor. Alianças com as esferas subnacionais } \\
\text { e a sociedade civil para construir e efetivar o } \\
\text { projeto de desenvolvimento. }\end{array}$ \\
\hline $\begin{array}{l}\text { Conceito de } \\
\text { região }\end{array}$ & Região natural & $\begin{array}{l}\text { Regiões funcionais e polos de } \\
\text { desenvolvimento (região operacional) }\end{array}$ & $\begin{array}{l}\text { Eixos nacionais de } \\
\text { integração e } \\
\text { desenvolvimento (região } \\
\text { competitiva) }\end{array}$ & $\begin{array}{l}\text { Macro, meso e microrregiões geográficas (IBGE), } \\
\text { economicamente mais ou menos dinâmicas e } \\
\text { distributivas (renda da população). } \\
\text { (Região-Programa) }\end{array}$ \\
\hline $\begin{array}{l}\text { Objetivos da } \\
\text { regionalização }\end{array}$ & $\begin{array}{l}\text { Divisão prática única para fins } \\
\text { administrativos e estatísticos } \\
\text { (conhecimento da realidade do } \\
\text { país). Legitimação da atuação do } \\
\text { Estado e integração territorial. }\end{array}$ & $\begin{array}{l}\text { Crescimento econômico, industrial e } \\
\text { urbano. Constituição e fortalecimento } \\
\text { do mercado interno. Integração } \\
\text { territorial (rede urbana) e integração } \\
\text { das áreas mais dinâmicas ao mercado } \\
\text { internacional (polos). }\end{array}$ & $\begin{array}{l}\text { Modernização seletiva de } \\
\text { sistemas logísticos (redes de } \\
\text { transporte, energia e } \\
\text { comunicação) para ampliar } \\
\text { as exportações brasileiras } \\
\text { (commodities). Integração } \\
\text { internacional e competitiva } \\
\text { das áreas dinâmicas e } \\
\text { modernizadas do território } \\
\text { brasileiro. }\end{array}$ & $\begin{array}{l}\text { Redução das desigualdades e valorização das } \\
\text { diversidades (ativos) regionais. Inclusão de } \\
\text { regiões menos dinâmicas e distributivas no } \\
\text { processo de desenvolvimento. Desconcentração } \\
\text { da produção e da renda. Integração competitiva } \\
\text { das regiões no mercado nacional, sul-americano e } \\
\text { internacional. Democratização do planejamento e } \\
\text { fortalecimento da coordenação } \\
\text { intergovernamental na gestão descentralizada e } \\
\text { integrada das políticas públicas. Estabelecimento } \\
\text { de diferentes escalas de informação, ação e } \\
\text { integração das políticas no território. }\end{array}$ \\
\hline
\end{tabular}

Fonte: elaboração própria.

69 "Em primeiro lugar, o desenvolvimentismo, isto é, a ideologia de superação do subdesenvolvimento nacional com base numa estratégia de acumulação de capital na indústria, só viria a tornar-se hegemônico na segunda metade dos anos 50. No período 1930-45, o que ocorria era, principalmente, uma primeira e limitada tomada de consciência da problemática da industrialização por parte de uma nova elite técnica, civil e militar, que então se instalava nas instituições de orientação e controle implantadas pelo Estado centralizador pós-1930" (BIELSCHOWSKY, 2000, p.250). 
A regionalização como ferramenta do planejamento compreende a institucionalização de recortes regionais na busca de programar uma ação específica (analítica, política, econômica e social) e pressupõe objetividade, fím, instrumentalidade, articulando-se com ideologias e recursos político-administrativos (RIBEIRO, 2004b). A multiplicidade de elementos que caracterizam a existência das regiões geográficas cede lugar a um conjunto de variáveis pré-estabelecidas, segundo a finalidade a se alcançar, e acompanha a transformação da eficácia em meta política e a imposição do agir instrumental e estratégico: assim se distingue a região como fato e a regionalização como ferramenta (RIBEIRO, 2004). Não existe uma regionalização à priori, o estabelecimento dos recortes regionais depende dos objetivos propostos pelo planejamento público.

No caso da criação de regiões de desenvolvimento, o Estado brasileiro procurou imprimir uma determinada racionalidade espacial ao funcionamento dos motores do desenvolvimento, visando potencializá-los, articulando esforços políticos, econômicos, técnicos e sociais. Esse tipo de regionalização resulta da identificação e delimitação das coerências espaciais entre dois elementos fundamentais: o estado das técnicas e o estado da política (SANTOS, 2000, p.23), em um dado momento. A regionalização procura estabelecer uma relação entre os arranjos institucionais e objetivos das políticas públicas com as oportunidades e limitações oferecidas pelos usos do território para sua efetivação, visando aumentar a capacidade estatal de comando sobre a evolução da divisão territorial do trabalho. $\mathrm{O}$ Estado pode elaborar diferentes regionalizações conforme ocorrem mudanças nas propostas de desenvolvimento e na própria dinâmica espacial, enfatizando alguns critérios de diferenciação das áreas em detrimento de outros. A regionalização pode resultar ainda na criação de instâncias de coordenação política e participação e controle social, colaborando para a democratização do planejamento.

As políticas regionais continuam incidindo sobre a capacidade do Estado de comandar e coordenar as forças produtivas no território, mas os motores da divisão internacional do trabalho, suas redes técnicas, financeiras e políticas, extrapolam as fronteiras nacionais e reproduzem desigualdades sociais e regionais. Faz-se necessário, portanto, levar em conta a natureza hierárquica da geração e apropriação 
da riqueza entre as múltiplas escalas intermediárias que se impõem entre os lugares e o mundo, além das diferentes escalas de formulação da política (BRANDÃO, 2007).

O agravamento do federalismo competitivo (ABRUCIO, 2005) e das desigualdades socioespaciais, na década de 1990, são problemas associados e que devem ser enfrentados na busca por um federalismo mais cooperativo, pois as desigualdades socioespaciais também acarretam desigualdades quanto às capacidades técnicas, políticas e financeiras dos governos para a formulação e execução das políticas. A coordenação intergovernamental e o papel redistributivo e regulador do governo federal tendem a reverter essa situação (ARRETCHE, 2010). As políticas regionais podem ser um instrumento de ajustamento das divergências políticoinstitucionais ou podem acentuá-las, caso priorizem apenas uma determinada ação setorial (ROCHA NETO \& BORGES, 2011). Neste caso, ressalta-se que a existência de estratégias regionais setoriais, nem sempre vinculadas a uma proposta mais ampla de desenvolvimento, relacionadas, sobretudo, à descentralização políticaadministrativa e à organização e desconcentração da oferta de serviços públicos no território, podem criar limitações para um planejamento regional de caráter mais amplo e integrado. As regiões setoriais sobrepostas geram uma visão da dinâmica territorial extremamente recortada e setorializada, dificultando o estabelecimento de nexos e coerências funcionais entre as políticas públicas e destas com as demandas sociais e econômicas, impondo sérias limitações para a elaboração de propostas de planejamento mais integradas territorialmente e que visem o desenvolvimento (MELGAÇO E ALBUQUERQUE, 2004).

Os processos histórico-estruturais dos usos do território também se impõem como condição para a implantação de políticas regionais de desenvolvimento. As heranças territoriais e os usos atuais caracterizam-se por situações de extrema concentração e rarefação das atividades, infraestruturas, investimentos, população, informação, tecnologias, entre outros (SANTOS \& SILVEIRA, 2001). O Nordeste e a Amazônia, por exemplo, persistem como "questões regionais", ainda que, nos últimos dez anos, as desigualdades estejam sendo enfrentadas com maior efetividade (ARAÚJO, 2012).

As políticas de caráter regional podem contribuir ou não para a diminuição das desigualdades socioespaciais, a depender da sua condução, sendo classificadas 
atualmente em três tipos (ARAÚJO, 2012): (i) políticas implícitas de desenvolvimento regional, quando as políticas setoriais trabalham a questão regional; (ii) políticas regionais explícitas, construídas para enfrentar diretamente o debate da questão regional; e (iii) políticas territoriais, que estimulam o protagonismo dos estados e regiões na condução de projetos específicos de desenvolvimento econômico e combate às desigualdades, a partir da leitura de seus territórios.

O enfrentamento das desigualdades é tão importante quanto a valorização das diversidades regionais (SILVEIRA, 2011; ARAÚJO, 2012), demandando a leitura do território usado e a formulação de políticas em diversas escalas: nacional, macro, meso e microrregional. Ao mesmo tempo, "o planejamento urbano-regional atual não mais comporta fórmulas pré-fabricadas", devendo ser fundamentado "na própria história contemporânea, história conjunta do mundo e dos lugares, que devemos nos inspirar tanto para entender os problemas, como para tentar resolvê-los" (SANTOS, 1991, p.39).

A regionalização deve considerar, assim, os interesses e práticas dos distintos agentes e suas influências nas esferas da vida coletiva (RIBEIRO, 2004, p.200), sendo necessário atentar para a relevância de identificar os agentes que definem os recortes regionais, isto é, identificar quem fala pela região: "quem se propõe a dizer: a região quer, a região luta por, a região reivindica, a região necessita de?", além da importância de identificar que recortes estão em confronto ${ }^{70}$ (VAINER, 1996, p.20).

As políticas regionais precisam valorizar a multiplicidade dos usos do território brasileiro, nem sempre hegemônicos (CATAIA, 2008; SILVEIRA, 2011). A federação é construída e reconstruída com base nas diversidades e nas desigualdades socioespaciais, tornando fundamental a criação de espaços institucionais de participação social no planejamento, que tenham como base os territórios e não os setores das políticas públicas (CATAIA, 2010). Os compromissos enunciados em políticas públicas precisam expressar interesses espacialmente referenciados nos diversos projetos dos agentes sociais e econômicos, fundamentando um planejamento compartilhado entre Estado e a Sociedade, com vistas à transformação social (STEINBERGER, 2006).

70 "É, enfim, romper com o fetichismo que toma a região como inscrita, por si, no território" (VAINER, 1996, p.20) 
As diversidades e desigualdades dos usos do território brasileiro e a organização política da federação, que garante autonomia para mais de cinco mil municípios, criam limitações para o planejamento regional. Ao longo do tempo, a "questão regional" tornou-se mais complexa, demandando do planejamento brasileiro considerações sobre: (i) as desigualdades e diversidades dos usos do território na formulação das políticas públicas; (ii) os distintos interesses e agentes públicos e privados envolvidos direta ou indiretamente nos projetos regionais; (iii) as diferentes escalas espaciais e temporais dos eventos e das ações que interferem no projeto regional; (iv) a complexa relação entre redes e regiões na estruturação da divisão internacional do trabalho; (v) as dificuldades de coordenação e cooperação intergovernamentais no sistema federativo brasileiro, e os problemas de integração das políticas públicas setoriais nos lugares; e (vi) a coexistência no território de diferentes políticas de caráter regional, nem sempre convergentes quanto aos seus instrumentos, recortes espaciais e objetivos.

Essas questões que representam hoje alguns dos principais desafios para a elaboração de políticas públicas de caráter regional no Brasil incidem, inclusive, sobre a estratégia de regionalização do Sistema Único de Saúde. Nesse sentido, é importante verificar de que maneira tais questões têm sido enfrentadas pela política nacional de saúde e através dos desdobramentos do processo de regionalização do SUS nos estados. 


\section{Capítulo 2. 0 enfoque regional nas diretrizes nacionais de planejamento e gestão do Sistema Único de Saúde (2001 -}

\section{1)}

A regionalização da assistência à saúde está prevista na Constituição Federal $^{71}$ de 1988 e na Lei Orgânica da Saúde ${ }^{72}$ de 1990 como estratégia para auxiliar a descentralização político-administrativa do Sistema Único de Saúde (SUS), através da organização das ações e serviços em redes assistenciais integradas e hierarquizadas. Desde então, foram publicadas três diretrizes nacionais de regionalização do sistema: a Norma Operacional de Assistência à Saúde - Noas (2001/02); o Pacto pela Saúde (2006); e o Decreto n 7.508 (2011).

Em dez anos, as mudanças nas diretrizes nacionais distinguiram três fases da proposta de regionalização do SUS: a primeira, caracterizada pela "regionalização normativa", que deu início ao processo; a segunda, caracterizada pela "regionalização viva", que conferiu uma nova institucionalidade ao processo e favoreceu a transição para a terceira fase; esta, denominada aqui como "regionalização contratualizada", que introduziu novas regras e definições, novos instrumentos e objetivos, conferindo maior complexidade técnica, informacional, normativa e política ao processo.

71 “Art. 198. As ações e serviços públicos de saúde integram uma rede regionalizada e hierarquizada e constituem um sistema único, organizado de acordo com as seguintes diretrizes: I descentralização, com direção única em cada esfera de governo; II - atendimento integral, com prioridade para as atividades preventivas, sem prejuízo dos serviços assistenciais; III - participação da comunidade." (Brasil. Constituição Federal, 1988)

72 "Art. 7. As ações e serviços públicos de saúde e os serviços privados contratados ou conveniados que integram o Sistema Único de Saúde - SUS são desenvolvidos de acordo com as diretrizes previstas no artigo 198 da Constituição Federal, obedecendo ainda aos seguintes princípios: IX - descentralização político-administrativa, com direção única em cada esfera de governo: a) ênfase na descentralização dos serviços para os municípios; b) regionalização e hierarquização da rede de serviços de saúde. Art. 16. À direção nacional do Sistema Único de Saúde-SUS compete: III - definir e coordenar os sistemas: a) de redes integradas de assistência de alta complexidade; b) de rede de laboratórios de saúde pública; c) de vigilância epidemiológica; e d) de vigilância sanitária." (Brasil, Lei $n .^{\circ} 8.080$ de 19 de Setembro de 1990) 


\subsection{A "regionalização normativa": Norma Operacional de Assistência à Saúde (2001)}

Durante a década de 1990, no contexto da agenda neoliberal, a política de saúde brasileira acompanhou a tendência de contenção de gastos, expansão da prestação privada e fragmentação das políticas sociais, sem a formulação de um plano nacional de saúde abrangente (MACHADO, 2006). As estratégias-chave foram a descentralização, o incentivo às parcerias público-privadas, o estímulo ao controle social e as ações focalizadas em áreas de pobreza (VIANA \& SILVA, 2012). Predominava o planejamento gerencialista, com estratégias de regulação e de curto prazo (MACHADO et al. 2010, p.2373).

O governo federal priorizou o Programa Saúde da Família (PSF), cujo caráter inovador era o foco na família e na comunidade (MACHADO, 2006). A noção de territorialidade - ligada às ideias de comunidade e desigualdades locais/intra-urbanas - foi muito valorizada na organização das ações do PSF. Entretanto, como afirma Machado (2006; 2007), durante a década de 1990, o predomínio de políticas de corte nacional e escassa consideração sobre as diversidades regionais associados à fragmentação das ações federais e à ênfase municipalista (com baixa coordenação intergovernamental) prejudicaram a formulação de políticas de redução das desigualdades em saúde no país.

A maior parte dos gastos federais em saúde se destinou à manutenção da rede assistencial já existente, por meio de pagamento de serviços, programas de investimentos ou transferências para estados e municípios, concentrando os recursos federais nas regiões brasileiras historicamente mais favorecidas pela densidade e diversidade dos serviços públicos de saúde, mantendo as desigualdades regionais (OLIVEIRA, 2005 E GADELHA et al., 2011).

A descentralização enfatizou a atenção primária e o fortalecimento dos sistemas municipais de saúde, através do Programa Saúde da Família (PSF), e ocorreu sob forte indução federal, através de normas e incentivos, com escassa consideração das diversidades regionais (LEVCOVITZ et al, 2001; MACHADO et al, 2010). A municipalização, com tendência "à autonomização dos municípios" contrastou com a própria noção do sistema único, hierarquizado, descentralizado, regionalizado e integrado (VIANA, 1994, p.168-9). A descentralização ocorreu com 
ênfase na relação direta entre governo federal e governos municipais. Três graves problemas surgiram a partir daí: (i) a norma era igual para todos os municípios, mas estes eram muito desiguais entre si em termos do seu poder econômico e político no contexto da federação; (ii) ao vir desacompanhada de uma proposta de regionalização do sistema, a descentralização contribuiu para acirrar as desigualdades socioespaciais existentes, dificultando a cooperação intergovernamental ${ }^{73}$ e maiores avanços na efetivação dos princípios e integração regional dos serviços do SUS; (iii) a relação direta entre União e municípios fragilizou o papel das esferas estaduais no planejamento e coordenação das redes assistenciais regionalizadas.

O governo federal manteve uma comunicação mais direta com os municípios, em detrimento de uma mediação mais presente dos estados nos investimentos e organização das redes assistenciais. As normas de gestão e descentralização do SUS e os mecanismos de financiamento federais indutores desse processo, possibilitaram uma atuação dos municípios mais regulada e dependente do nível federal. Esse foi um dos aspectos que contribuiu para a fragilização do papel da esfera estadual como articuladora e planejadora regional do SUS.

Ao transferir para os municípios a sua rede ambulatorial e parte da rede hospitalar, alguns estados abandonaram seu papel de prestador de serviços, mas não se capacitaram para assumir suas novas atribuições. $\mathrm{O}$ processo de descentralização instaurado pelo SUS, centrado na relação União-municípios, deixou à margem os estados como instâncias de planejamento, financiamento, avaliação e controle. Com isso, permaneceram na disputa pelo papel de prestador, com o SUS deixando de dispor de uma instância articuladora e otimizadora dos recursos disponíveis em cada município, atravancando assim a possibilidade de se programar e de operar redes de serviços de âmbito regional. (YUNES, 1999, p.68).

Embora tenha garantido a construção do SUS, sem dúvida a descentralização logo impôs limitações para avanços na universalização da saúde no país. Destaca-se que: (i) o sistema não poderia garantir a integralidade do atendimento na circunscrição de um único município e (ii) o enfrentamento das desigualdades em

73 A Constituição Federal aprovou a autonomia municipal, mas o contexto neoliberal e da globalização estabeleceu um clima de competição entre os entes, muito bem exemplificado pelas guerras fiscais na disputa por investimentos privados nacionais e estrangeiros. A implantação do SUS ocorreu nesse clima de competição entre os entes pela disputa de investimentos públicos e privados. 
saúde dependia da combinação de diferentes estratégias e políticas, articuladas entre os três níveis de governo, atendendo às características históricas, estruturais, conjunturais, territoriais, políticas e institucionais dos estados e regiões brasileiras.

O municipalismo no Brasil, num contexto de Estado mínimo, entrada de capital estrangeiro, inserção do país na globalização e aumento das desigualdades socioespaciais, incentivou uma forte disputa entre os entes municipais pela atração de investimentos públicos e privados, incluindo aqueles destinados aos serviços de saúde. Os municípios mais populosos, economicamente dinâmicos e concentradores das variáveis do meio geográfico (técnica, ciência e informação), possuíam maior atratividade para os investimentos em saúde e manutenção de equipamentos, profissionais e tecnologias assistenciais.

O grau e o perfil de implementação do SUS acompanhou as desigualdades e a concentração do desenvolvimento econômico nas regiões brasileiras (ALMEIDA, 2005), revelando debilidades na capacitação dos municípios para responder às distintas modalidades de gestão do sistema, deixando a maior parte apenas com a gerência de serviços públicos de saúde sob sua jurisdição e não com a gestão da saúde no âmbito local (ELIAS et al, 2001:17).

Está claro, no entanto, o caráter paradoxal de tais medidas [de descentralização] quando, no início da década de 90, o país adotara como estratégia o ajuste macroeconômico, a partir de planos de estabilização monetária e da abertura da economia para atrair capitais externos e de redução dos gastos públicos, e que acabaram por acentuar os problemas e estimular as demandas por programas sociais. Essa conjuntura, associada à escassa tradição democrática e à debilidade das estruturas de governo, principalmente das esferas subnacionais, tem se traduzido na baixa capacidade dos governos para enfrentar a complexidade daquelas questões e as consequências da autonomia conferida constitucionalmente às esferas subnacionais. Isso, por sua vez, acaba também por colocar sérios constrangimentos ao processo de descentralização das políticas públicas (NASCIMENTO, 2001, p.30).

As Normas Operacionais Básicas (NOBs) de 1991, 93 e 96, que delinearam o processo de descentralização da política de saúde, apesar de não abordarem diretamente a regionalização do SUS, contribuíram com a criação de alguns elementos que seriam importantes para o início dessa estratégia. Dentre eles destacase o estabelecimento de referências intermunicipais, ordenadas por instrumentos de planejamento e gestão, e de espaços de negociação intergovernamentais. 
A NOB de 1991 reconheceu a necessidade de "organização das referências intermunicipais no financiamento das atividades ambulatoriais e na política de investimento" (ELIAS et al, 2007, p.186). A NOB 1993 criou as Comissões Intergestoras Bipartites (CIBs) nos estados e a Comissão Intergestores Tripartite (CIT) no âmbito nacional, formatando "um processo de normalização das relações intragovernamentais" (COSTA, 2001, p.312). Finalmente, a NOB 1996 introduziu a Programação Pactuada Integrada (PPI), que pode ser considerado o primeiro instrumento de regionalização do SUS, porque determinou a responsabilidade de cada município na garantia de acesso da população aos serviços de saúde e definiu os encaminhamentos de pacientes entre os municípios, "sempre por intermédio de relações entre gestores municipais, mediadas pelo gestor estadual" (BRASIL, 1996, p.18).

O consórcio intermunicipal de saúde ${ }^{74}$ também surgiu como um instrumento para a organização regional das políticas de saúde, sendo incentivado a partir da publicação da NOB 96 e outros documentos ministeriais. Previsto na Lei $\mathrm{n}^{\circ}$ 8.080/1990 (artigo $\mathrm{n}^{\circ} 10$ ), e amparados por experiências da década de 1980, a organização dos consórcios administrativos intermunicipais era uma estratégia de regionalização da oferta pública, através da articulação e mobilização de municípios que compartilhavam necessidades comuns em saúde, sobretudo relacionadas à compra de serviços e à organização das regras de financiamento e dos fluxos assistenciais regionais (COSTA \& RIBEIRO, 2000). Os consórcios surgiram como uma alternativa de curto e médio prazo para a resolução de dificuldades comuns que não encontravam respostas na fragilidade técnica e política da estrutura regional do SUS (VIANA et al. 2008).

As Comissões Intergestores Bipartite (CIBs) tornaram-se os espaços de negociação e aprovação das PPIs e, posteriormente, de negociação da regionalização do sistema. A PPI foi usada como um dos instrumentos de planejamento regional do SUS até 2010, sendo extinta pelo Decreto $n^{0} 7.508 / 2011$.

\footnotetext{
74 "O ministério lança também o documento '1997 - O Ano da Saúde no Brasil' (MS, 1997b), onde cita a necessidade de criação dos consórcios. No mesmo ano, convoca a primeira oficina sobre consórcios, editando o manual 'Os Consórcios e a Gestão Municipal em Saúde' (MS, 1997c)." (LIMA AP, 2000, p.987).
} 
Entre 1996 e 2001, a PPI não havia sido implementada na maior parte dos estados, "prevalecendo a utilização de critérios pouco participativos para distribuição dos recursos financeiros no âmbito intraestadual" (QUEIROZ, 2004, p.20). Tal situação dificultava a integração intermunicipal e o planejamento e a coordenação das SES, aumentando o risco de atomização dos sistemas municipais, as barreiras de acesso a pacientes de outros municípios e a falta de racionalidade no processo de incorporação tecnológica no sistema (SOUZA, 2001). Ainda assim, o processo de condução da PPI pelas Comissões Intergestores Bipartite fortaleceu este fórum como um espaço permanente de negociação intergovernamental (LEVCOVITZ et al, 2001).

Os limites da descentralização para a consolidação do SUS levaram à proposição da Norma Operacional de Assistência à Saúde - Noas (BRASIL, 2001/2002). Formulada sob a coordenação do Ministério da Saúde, em parceria com o Conselho Nacional dos Secretários Estaduais de Saúde (Conass), o Conselho Nacional dos Secretários Municipais (Conasems) e com o Conselho Nacional de Saúde e aprovada na Comissão Intergestores Tripartite (CIT) (SOUZA, 2001).

A Noas definiu as diretrizes, os instrumentos de planejamento e a responsabilidade dos entes sobre o processo de regionalização do sistema de saúde brasileiro. A regionalização estava baseada na lógica do planejamento integrado e na noção de sistema de saúde funcional e resolutivo (BRASIL, 2002), organizado a partir de regiões de saúde (micro e macro), módulos assistenciais, redes assistenciais regionalizadas e hierarquizadas e da solidariedade entre os entes federados.

A ideia de sistema de saúde funcional tem forte inspiração no Relatório Dawson, de 1920 (Informe, 1964), que serviu de referência para a construção do sistema nacional de saúde britânico e outros sistemas universais. Segundo este documento, a definição das funções de cada tipo de ações e serviço (gerais, especiais, laboratórios e outros serviços auxiliares) e sua lógica de distribuição e referência no território (centros primários e secundários, localizados em zonas urbanas mais e menos adensadas e zonas rurais), determinava a forma de organização dos serviços em redes hierarquizadas e regionalizadas. Tratava-se do papel do Estado de organizar e gerir a divisão territorial do trabalho em saúde e suas redes regionalizadas para garantir o acesso universal à saúde, conforme as especialidades dos serviços, sua 
concentração nos lugares, as referências estabelecidas para garantir a integralidade do cuidado, as informações sobre tratamentos e demandas da população e a abrangência espacial dos fluxos assistenciais. O Relatório também sugeriu que cada região estivesse sob a coordenação de uma única autoridade de saúde e que fosse subdividida em distritos, microrregiões ou sub-regiões, conforme os níveis de assistência. A partir desse relatório, a organização de redes regionalizadas e hierarquizadas, sob a responsabilidade do Estado, tornou-se uma estratégia de sistemas nacionais e universais de saúde, para garantir o acesso e diminuir as desigualdades em saúde (KUSCHNIR \& CHORNY, 2010).

$\mathrm{Na}$ política de saúde brasileira, a ideia de sistema de saúde funcional e resolutivo introduzido pela Noas trouxe a regionalização como macroestratégia de organização da assistência pública, visando à integração do sistema em redes hierarquizadas, o ordenamento dos fluxos assistenciais intermunicipais e o combate às desigualdades no acesso à saúde. Havia questões importantes a serem equalizadas, tanto do ponto de vista operacional do sistema (regulação, financiamento, referências entre serviços, distribuição dos serviços e garantia de acesso), como do ponto de vista da relação intergovernamental (efetivação de instrumentos pactuados sobre a distribuição dos fluxos assistenciais, recursos financeiros, planejamento integrado, mudanças na lógica de financiamento pela oferta e definição de atribuições a estados e municípios). A macroestratégia da regionalização do SUS teria que enfrentar uma situação complexa, que se caracterizava pela grande desigualdade regional das condições de funcionamento, gestão e financiamento do sistema de saúde.

Três pontos eram cruciais para a implantação da regionalização: (i) a elaboração de novos instrumentos de planejamento integrado, com a definição das responsabilidades de cada ente e o estabelecimento do elenco mínimo de procedimentos na atenção básica, média e alta complexidade; (ii) o fortalecimento do papel dos estados como principais responsáveis pela regionalização, atuando na coordenação, regulação, no financiamento e planejamento das redes regionalizadas; (iii) mudanças nas regras de habilitação da gestão do sistema pelos estados e municípios, para tornarem-se condizentes com os objetivos e propostas da regionalização. 
A Noas veio resgatar a noção sistêmica de organização do SUS, procurando estabelecer uma articulação entre estados e municípios. Tinha como objetivos específicos: 1. Definição do papel dos estados no planejamento regional, dado que nem tudo se resolvia no município; 2. Diminuição das desigualdades regionais em saúde, considerando a discrepância das realidades municipais e as necessidades em saúde; 3. Definição das regiões e organização de redes assistenciais regionalizadas, hierarquizadas para integrar os serviços de forma sistêmica; 4. Ordenamento dos fluxos financeiros entre os municípios relativos aos repasses federais para média e alta complexidade, de forma a regular os investimentos em políticas e serviços específicos e organizar o acesso regional dos pacientes; 5. Ampliação do acesso e melhoria da qualidade da Atenção Básica, com definição dos procedimentos mínimos a serem ofertados e repasses federais vinculados (Piso de Atenção Básica Ampliado); 6. Ampliação dos investimentos e do acesso aos serviços de média e alta complexidade através da definição de procedimentos mínimos a serem ofertados e repasses federais vinculados (valor per capita nacional mínimo, com destinação descrita na Programação Pactuada e Integrada - PPI); 7. Implantação de um sistema de controle, regulação e avaliação do sistema pactuado entre os três gestores.

Pela primeira vez, a política nacional de saúde expressava a necessidade do poder público em ordenar a divisão territorial do trabalho na saúde. Essa tarefa demandava a identificação de redes de serviços, fluxos assistenciais intermunicipais, polos especializados em determinada oferta de serviços, da distribuição dos recursos financeiros, tecnológicos, dos investimentos no sistema e o conhecimento das necessidades em saúde. As secretarias estaduais de saúde eram as principais responsáveis pela definição dos limites regionais, o que dependia fundamentalmente de suas capacidades políticas e técnicas de coordenação, regulação e planejamento da divisão do trabalho e da negociação com os municípios. Ao contrário do processo de descentralização ocorrido durante a década de 1990, que focou o papel dos municípios, no início dos anos 2000, o foco da regionalização é o papel do nível estadual.

As secretarias estaduais de saúde deveriam elaborar o Plano Diretor de Regionalização (PDR) e o Plano Diretor de Investimentos (PDI) para estabelecer o papel de cada município no sistema, garantir instrumentos de referência do acesso 
nas redes assistenciais, evitar a sobreposição de serviços e tecnologias, assim como, vazios assistenciais e orientar as prioridades de investimento dos recursos estaduais e federais em média e alta complexidade.

O planejamento regional deveria organizar a assistência no que se refere à integração dos serviços, à regulação do acesso, aos investimentos prioritários e à definição e ampliação do rol de procedimentos ofertados nos três níveis de atenção. Havia uma preocupação em garantir a resolutividade de um conjunto de patologias e agravos em cada um dos diferentes níveis de assistência, visando também a economia de escala.

O Plano Diretor de Regionalização deveria conter a descrição do desenho regional de saúde, com a identificação do papel dos municípios (sede, polo e demais), o mapa da regionalização, informações sobre a abrangência populacional por módulo assistencial e região de saúde, a proposta de estruturação das redes de referência de serviços especializados e o cronograma de implantação do PDR. O Plano deveria contemplar ainda uma perspectiva de redistribuição geográfica de recursos tecnológicos e humanos, explicitando o desenho futuro e desejado da regionalização estadual, prevendo os investimentos necessários para a conformação das novas regiões/microrregiões e módulos assistenciais, visando possibilitar o acesso do cidadão a todas as ações e serviços necessários para a resolução de seus problemas de saúde, o mais próximo possível de sua residência (BRASIL, 2002, p.11)

Já o Plano Diretor de Investimentos deveria trazer a descrição, por microrregião, dos investimentos necessários para a conformação de sistemas funcionais e resolutivos de saúde, e um quadro sobre as necessidades de investimento para garantir a implementação do PDR, considerando a suficiência tecnológica para oferta de serviços necessários às microrregiões e módulos assistenciais. O PDI deveria atender às prioridades de intervenção identificadas em cada região/microrregião.

A Programação Pactuada e Integrada (PPI), primeiro instrumento de planejamento do SUS de caráter regional, introduzida pela Norma Operacional Básica de 1996 (NOB 96), foi retomada pela Noas. Envolvendo as atividades ambulatoriais, hospitalares e de vigilância em saúde, organizava a alocação de 
recursos pelos três entes federados e estabelecia as responsabilidades de cada município com a garantia de acesso da população aos serviços de saúde, seja no próprio município ou por meio de encaminhamento a outros municípios. A relação intermunicipal expressa pela PPI era definida através de um processo ascendente de planejamento, mediada pelo gestor estadual e negociada na CIB, e deveria conformar as redes regionalizadas e hierarquizadas de serviços. Órgãos federais, estaduais e municipais, assim como prestadores conveniados e contratados, tinham obrigação de descrever sua programação para o atendimento no município e os demais referenciados. A programação das ações considerava os critérios e parâmetros definidos pelas Comissões Intergestores, aprovados pelos Conselhos (BRASIL, 1996, p.12-13).

A qualificação da atenção básica nos municípios era uma questão central para melhorar a assistência e organizar as redes regionalizadas, sendo identificadas "as áreas estratégicas mínimas, relacionadas a problemas de saúde de abrangência nacional (saúde da mulher, saúde da criança, saúde bucal, controle da hipertensão e diabetes, controle da tuberculose e eliminação da hanseníase)" para direcionar os investimentos em saúde (SOUZA, 2001, p.454). Os gestores estaduais e municipais poderiam ainda definir, complementarmente, outras áreas estratégicas relacionadas às especificidades epidemiológicas locais (SOUZA, 2001).

A proposta da Noas definia rol mínimo de ações e serviços de atenção básica para todos os municípios brasileiros, sem exceção, e um rol mínimo de ações e serviços de média complexidade e habilitação na gestão em saúde como critérios do recorte regional. O conjunto mínimo de serviços de média complexidade compreendia as atividades ambulatoriais de apoio diagnóstico e terapêutico e de internação hospitalar. Apesar da preocupação com a atenção básica, as redes de referência eram pensadas a partir de serviços de média e alta complexidade, com preponderância daqueles considerados estratégicos, isto é, mais especializados e concentrados territorialmente, com maior densidade tecnológica e de alto custo para o sistema de saúde.

O desenho regional era determinado pelos seguintes critérios: especialidades oferecidas pelos municípios polos; escala de abrangência intermunicipal da referência de acesso; população atendida; e habilitação da gestão. O desenho regional 
também deveria atentar para as características demográficas, socioeconômicas, geográficas, sanitárias, epidemiológicas, relações entre municípios, entre outras.

Mas tratava-se, fundamentalmente, de critérios de regionalização baseados na concentração e especialização da oferta assistencial, na economia de escala e os graus de descentralização política.

De acordo com a Noas, a região de saúde era definida como:

Região de saúde - base territorial de planejamento da atenção à saúde, não necessariamente coincidente com a divisão administrativa do estado, a ser definida pela Secretaria Estadual de Saúde, de acordo com as especificidades e estratégias de regionalização da saúde em cada estado, considerando as características demográficas, socioeconômicas, geográficas, sanitárias, epidemiológicas, oferta de serviços, relações entre municípios, entre outras. Dependendo do modelo de regionalização adotado, um estado pode se dividir em macrorregiões, regiões e/ou microrregiões de saúde. Por sua vez, a menor base territorial de planejamento regionalizado, seja uma região ou uma microrregião de saúde, pode compreender um ou mais módulos assistenciais. (BRASIL, 2002, p.10)

Os conceitos de Módulo Assistencial, de Município-sede do módulo assistencial (relacionados com os graus de descentralização da gestão - Gestão Plena do Sistema Municipal - GPSM ou Gestão Plena da Atenção Básica - GPAB-A), de Município-pólo (GPSM ou GPAB-A) e Unidade territorial de qualificação na assistência à saúde, utilizados para o recorte das microrregiões de saúde nos estados (Figura 1, a seguir), foram definidos como:

Módulo Assistencial - módulo territorial com resolubilidade correspondente ao primeiro nível de referência, definida no Item 8 Capítulo $\mathrm{I}^{75}$ desta Norma, constituído por um ou mais municípios, com área de abrangência mínima a ser estabelecida para cada Unidade da Federação, em regulamentação específica, e com as seguintes características: - conjunto de municípios, entre os quais há um municípiosede, habilitado em Gestão Plena do Sistema Municipal/GPSM ou em Gestão Plena da Atenção Básica Ampliada (GPAB-A), com capacidade de ofertar a totalidade dos serviços de que trata o Item 8 - Capítulo I desta Norma, com suficiência, para sua população e para a população de outros municípios a ele adscritos; ou - município em Gestão Plena do

\footnotetext{
75 “Capítulo I, Item 8: Definir um conjunto mínimo de procedimentos de média complexidade como primeiro nível de referência intermunicipal, com acesso garantido a toda a população no âmbito microrregional, ofertados em um ou mais módulos assistenciais. 8.1 Esse conjunto mínimo de serviços de média complexidade compreende as atividades ambulatoriais de apoio diagnóstico e terapêutico (M1) e de internação hospitalar, detalhadas no Anexo 3 desta Norma." (BRASIL, 2002, p.13)
} 
Sistema Municipal ou em Gestão Plena da Atenção Básica Ampliada (GPAB-A), com capacidade de ofertar com suficiência a totalidade dos serviços de que trata o Item 8 - Capítulo I para sua própria população, quando não necessitar desempenhar o papel de referência para outros municípios.

Município-sede do módulo assistencial (GPSM ou GPAB-A) município existente em um módulo assistencial que apresente a capacidade de ofertar a totalidade dos serviços de que trata o Item 8 Capítulo I, correspondente ao primeiro nível de referência intermunicipal, com suficiência, para sua população e para a população de outros municípios a ele adscritos.

Município-pólo (GPSM ou GPAB-A) - município que, de acordo com a definição da estratégia de regionalização de cada estado, apresente papel de referência para outros municípios, em qualquer nível de atenção.

Unidade territorial de qualificação na assistência à saúde - representa a base territorial mínima a ser submetida à aprovação do Ministério da Saúde e Comissão Intergestores Tripartite para qualificação na assistência à saúde. Deverá ser a menor base territorial de planejamento regionalizado com complexidade assistencial acima do módulo assistencial, conforme definido no PDR. Poderá ser uma microrregião ou uma região de saúde, de acordo com o desenho adotado pelo estado.

(BRASIL, 2002, p.10)

\section{Figura 1 - Qualificação das Microrregiões na Assistência à Saúde nos estados (exemplo)}

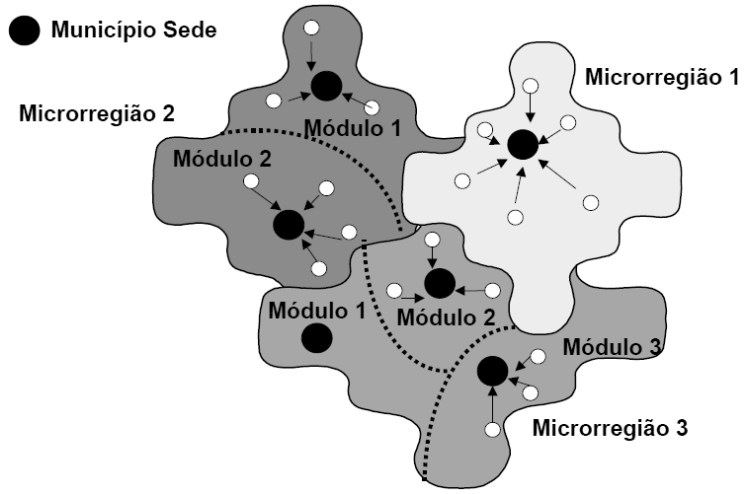

Fonte: Brasil (2001, p.20)

A NOAS estruturou, pela primeira vez, uma proposta concreta e detalhada de regionalização da assistência à saúde trazendo instrumentos de planejamento, gestão e financiamento, definição das responsabilidades e objetivos claros quanto aos desafios a serem superados. Apesar desse mérito, recebeu muitas críticas. A principal delas denominou essa proposta como uma "regionalização normativa" (BRASIL, 2004), devido à rigidez das regras e regulações federais sobre o processo (definições 
dos recortes e padrão de oferta dos serviços e repasses de recursos condicionados ao cumprimento das regras e requisitos mínimos por estados e municípios).

Essa crítica fundamentava-se principalmente em relação ao modelo federal de condução da descentralização do SUS, entre 1998 a 2002, cuja "intensa normatização atrelada aos incentivos financeiros teria gerado, entre outros fatores, uma excessiva burocratização das relações intergovernamentais e fragmentação acentuada dos mecanismos de transferência de recursos federais" (LIMA \& QUEIROZ, 2012, p. 235).

Apesar da forte indução federal, a implantação da regionalização do SUS encontrava limitações devido ao distanciamento entre as propostas normativas e as reais condições político-institucionais, estruturais, conjunturais dos estados e municípios para sua efetivação (QUEIROZ, 2004). A autora aponta como dois principais empecilhos para a implantação da Noas a necessidade de mudanças nas regras e condições políticas para habilitação de estados e municípios e o planejamento econômico da regionalização, dado que a região de saúde não é uma unidade executora de orçamento. Algumas modificações foram feitas na versão de 2001 da Noas, para atender às demandas técnicas, políticas e econômicas de estados e municípios.

As resistências apresentadas relacionavam-se, em parte, às dificuldades de alguns gestores estaduais no processo de transferência do comando de unidades assistenciais localizadas em municípios habilitados em GPSM, para os gestores municipais. Por outro lado, da parte dos gestores municipais, havia dúvidas sobre a conveniência do financiamento proposto para o PAB-A e EPM-1, bem como disputas locais no processo de definição de municípios-sede de módulo e pólos regionais, que se relacionavam às perdas de espaço e de recursos que poderiam advir deste novo recorte, ameaçando posições historicamente construídas e acirrando aspectos competitivos do relacionamento intermunicipal. [...] a NOASSUS 01/2002 (BRASIL 2002), cuja principal alteração consiste na possibilidade de configuração do módulo assistencial com municípiosede habilitado em GPABA, o que possibilita a persistência do comando sobre os serviços de média e alta complexidade pelo gestor estadual, dela decorrendo os demais ajustes. (QUEIROZ, 2004, p.24).

Ainda de acordo com a autora, até 2004, constataram-se a lentidão das habilitações municipais e a inexistência de regiões assistenciais qualificadas, por conta das dificuldades nas transferências de recursos para os níveis de referência assistencial regional. 
...o cálculo relativo às transferências per capita, para as sedes de módulo, dos recursos atualmente pagos por produção de serviços, foi considerado desvantajoso pelos gestores de municípios sedes de módulo que, cautelosamente, optaram por não assumir as responsabilidades previstas na norma. (QUEIROZ, 2004, p.29).

A regionalização sugerida pela NOAS e seus instrumentos de planejamento ajudaram a construir uma visão da organização regional do SUS focada mais nos fluxos assistenciais e sua relação com a configuração e hierarquização da rede urbana brasileira e menos focada nas disputas políticas e financeiras em torno da gestão regional do sistema. Os módulos assistenciais tinham uma definição muito rígida, estritamente técnica e normativa, o que dificultava a criação de regiões de saúde mais coerentes com a realidade dos lugares (BRASIL, 2004; ALMEIDA, 2005) e com a própria noção de região, organizada por conteúdos provenientes de diferentes escalas geográficas $^{76}$ (GUIMARÃES RB, 2005).

O funcionamento da divisão territorial do trabalho em saúde proposta pela Noas se aproximou claramente das noções de centralidade, hierarquia e complementaridade, propostos pela teoria dos lugares centrais de Chistaller (1933). A região é compreendida como um espaço homogêneo, definida prioritariamente pelas secretarias estaduais de saúde, caracterizada por um desenho próprio, uma determinada suficiência e hierarquização de serviços oferecidos pela rede assistencial, tendo como parâmetros a divisão territorial do trabalho na rede de saúde (especializações e capacidades municipais - polos, sedes - e dos recortes regionais) e as escalas dos fluxos assistenciais (áreas de abrangência dos recortes e referências municipais).

As regiões de saúde eram concebidas apenas como uma categoria de territorialização (recorte espacial da dinâmica assistencial), sem maior expressão da relação política e econômica de sua organização, dificultando a descentralização e a relação intergovernamental no processo de efetivação do PDR e da PPI (FLEURY \& OUVERNEY, 2007).

\footnotetext{
76 Por conta dos processos globalizados, as regiões abrigam conteúdos e eventos de diferentes dimensões escalares, isto é, que são de natureza internacional, nacional, regional e local. Como afirma Guimarães (2005), o sistema de saúde tem que lidar com essas múltiplas escalas geográficas dos acontecimentos, principalmente, no processo de regionalização do Sistema Único de Saúde. O autor faz uma crítica à regionalização da NOAS por não permitir essa visão das múltiplas escalas dos acontecimentos.
} 
A organização da divisão territorial do trabalho em saúde pelos estados dependia de uma reorganização das relações intergovernamentais, porque, por um lado, o governo federal ainda operava na lógica União-município e possuía um alto poder indutor das políticas através de seus mecanismos de transferências financeiras. Por outro lado, os municípios disputavam entre si os recursos estaduais e federais, cuja lógica de distribuição estava muito baseada na oferta de ações e serviços e reforçava o poder dos municípios polos e das metrópoles. O comando da regionalização passava, portanto, pelo governo federal, pelas SES, pelas metrópoles e polos municipais.

A visão federal sobre a organização regional do SUS era restrita pelas concepções normativa (cumprimento das regras de gestão, financiamento e responsabilidades da descentralização política), técnica (parâmetros e prioridades assistenciais nacionais) e econômica (eficiência dos gastos e escala de produção). Neste caso, sob forte influência do modelo neoliberal vigente no país, que se baseava no "primado da eficácia como conceito tomado da economia, e mais uma vez mantendo-se a tônica econômico-financeira sob a lógica da descentralização da saúde" (ELIAS et al, 2001:17).

A concentração territorial de recursos e serviços de média e alta complexidade e as disparidades nas condições de financiamento e gestão do SUS reforçavam as desigualdades regionais em saúde (ALMEIDA, 2005) e dificultavam o processo de regionalização. A lógica de financiamento do sistema vinculada à capacidade de oferta de ações e serviços e regulada pela série histórica de gastos e produção e pelas unidades existentes, reforçava as desigualdades em saúde, mantendo "a concentração de recursos nas áreas mais desenvolvidas e em ações nem sempre compatíveis com o perfil de necessidades da população" (SOUZA, 2001, p.452).

As NOBS e NOAS não foram capazes de realocar recursos ou de trazer novos, o que impediu a compensação entre municípios para a prestação de serviços, com problemas tanto para os municípios pequenos quanto para os maiores: o pequeno não tinha como "liberar" teto para o grande, que não tem como financiar a atenção para os menores. Como consequência, embora a descentralização tenha logrado conseguir avanços (atenção básica em todos os municípios, incremento do 
PSF e PACS, etc.), não foi capaz de permitir um mesmo grau de expansão nos serviços especializados, leitos hospitalares, terapia intensiva, cirurgias eletivas etc. A oferta desses serviços foi ampliada pelo setor privado, sem que o Estado fosse capaz de regulá-la adequadamente, salvo honrosas exceções (ASSIS et al., 2009, p.18). Ao mesmo tempo, o enfrentamento das desigualdades regionais estava constrangido pelas demandas da política econômica (SOUZA C, 2001) e por uma visão muito centrada num parâmetro nacional (per capita nacional, rol mínimo de ações e serviços de $\mathrm{AB}$, estratégias de média e alta complexidade conforme prioridades nacionais).

A implantação da Noas regulou o aumento das transferências federais para estados e municípios, entre 2002 a 2006, mas não provocou reduções significativas nas desigualdades regionais em relação aos recursos federais destinados à média e alta complexidade em saúde, dado que a população e a oferta estavam concentradas territorialmente, sobretudo nas áreas de maior dinamismo econômico. Na fase inicial, a regionalização não foi uma estratégia suficiente para vencer a situação das desigualdades, agravadas durante a década de 1990, resultantes da adoção do modelo de contenção dos gastos e equilíbrio fiscal, com falta de planejamento prévio para as transferências redistributivas, que restringiu, sobretudo, a autonomia dos estados (LIMA, 2007, 2008).

A desconcentração da oferta de serviços não foi alcançada de modo a diminuir consideravelmente as disparidades regionais, tanto por motivos macroestruturais - ajuste econômico e baixa capacidade de investimento dos estados e municípios (QUEIROZ, 2004) - quanto por motivos setoriais dos mecanismos de transferência ainda muito baseados na lógica da oferta (QUEIROZ, 2004; LIMA C, 2011).

$\mathrm{Na}$ verdade, a disparidade na capacidade de financiamento e planejamento das instâncias subnacionais prejudicou a regionalização. A implantação da NOAS evidenciou que as desigualdades socioespaciais estruturais do território brasileiro e o modelo de ajuste e estabilização econômica repercutiam negativamente na capacidade político-institucional e financeira dos estados para organizarem seus sistemas de saúde e o planejamento regional das redes assistenciais (QUEIROZ, 2004). 
A regionalização desenhada nos Planos Diretores Regionais não correspondeu à realidade da política de saúde pactuada entre estados e municípios e nem mesmo à dinâmica dos fluxos assistenciais intermunicipais, e não se tornou a principal referência para o planejamento do sistema (VIANA \& LIMA, 2011).

Não havia uma formulação mais elaborada, por parte do governo federal, sobre os diferentes usoss do território brasileiro e suas implicações para a organização, gestão e financiamento do sistema de saúde (VIANA et al., 2007). Essa tarefa foi designada aos estados, porém, sem que a maioria tivesse tradição de planejamento regional em saúde e mesmo capacidade técnica para tal elaboração. Independentemente disso, tratava-se de uma tarefa estratégica para as diferentes escalas de poder e que foi abdicada pelo governo federal ao focar os estados como os responsáveis pela regionalização do SUS. O Ministério da Saúde garantia um apoio técnico à elaboração dos planos de regionalização e da PPI e um aporte adicional de recursos (valor per capita nacional) para a expansão da média complexidade (SOUZA, 2001).

A PPI, o PDI e o PDR representavam instrumentos de planejamento de curto e médio prazo, sem o estabelecimento de um projeto regional mais amplo, com definição de metas de acesso, qualidade e investimentos articulados pelos três entes.

As Comissões Intergestores Bipartite tornaram-se espaços de negociação do processo de regionalização do SUS. Contudo, se por um lado vinham desempenhando um papel fundamental na operacionalização das diretrizes nacionais e na descentralização do sistema de saúde, por outro, reforçavam o papel do governo federal como regulador e indutor do processo de descentralização; tutelada por instrumentos da programação, controle e avaliação, cujos critérios, cálculos, regras e mecanismos de controle a serem respeitados e efetuados deixam pouco tempo e espaço para o planejamento e a viabilização de políticas, inclusive regionais (LIMA LD, 2001).

A política de saúde nos anos 90 perdeu sua dimensão integradora, no âmbito nacional, regional e estadual, privilegiando ações focalizadas e a "gestão local" como esfera capaz de responder a todas as necessidades da população, o que, na verdade, significou um "abandono por parte do Estado de seu papel ativo e determinante nas condições de vida da população" (NORONHA \& SOARES, 2001). Isso refletiu na 
estratégia de regionalização, pois seu foco estava mais voltado para os avanços na descentralização (habilitação) e para a responsabilização dos estados como planejadores e reguladores dos sistemas de referência intermunicipal de saúde, do que para a capacidade de articulação, coordenação e cooperação intergovernamentais e para a participação de atores não governamentais no processo. A Noas não foi suficiente para "incentivar mecanismos de co-gestão regional do SUS", sobretudo, considerando-se que "o poder político-institucional é exercido por um amplo conjunto de atores sociais" (GUIMARÃES RB, 2005, p.1024).

A "regionalização normativa" criou instrumentos com baixo potencial de promoção da gestão compartilhada e cooperativa do SUS, pouco abrangentes em termos dos conteúdos tratados e planejados e pouco efetivos quanto ao reforço do papel estratégico dos entes estaduais no planejamento em saúde.

Assim, a "regionalização normativa" amarrou o projeto regional à lógica da oferta, das habilitações e dos fluxos assistenciais e financeiros, reforçando as desigualdades e a competitividade entre os entes federados. Isso dificultou o alcance dos objetivos principais da regionalização: o fortalecimento da lógica sistêmica para além do nível municipal, o fortalecimento da atuação dos estados no planejamento e a diminuição das desigualdades socioespaciais em saúde. Também não induziu o aumento dos gastos públicos em saúde, a formulação de projetos regionais com metas de médio e longo prazo e tampouco a elaboração de uma visão territorial mais abrangente e estratégica, baseada em informações sobre as situações de saúde e suas relações com as situações geográficas dos lugares.

As críticas à NOAS e as mudanças na política de saúde subsidiaram uma nova proposta de regionalização do SUS, divulgada pelo Pacto pela Saúde (BRASIL, 2006). 


\subsection{A "regionalização viva”: Pacto pela Saúde (2006)}

A partir da segunda metade dos anos 2000, a política de saúde sofreu mudanças incrementais, com predominância de elementos de continuidade em relação à fase anterior, persistindo os problemas estruturais do sistema de saúde: financiamento limitado, fragmentação da política, distorções da relação públicoprivada e desigualdades em saúde (TEIXEIRA E PAIM, 2005; MACHADO et al, 2011; MENICUCCI, 2011).

Entre 2003 e 2008, o governo federal priorizou a atenção primária à saúde (Estratégia Saúde da Família), apresentando pequenas alterações em relação ao modelo da década de 1990, e também priorizou outras áreas frágeis do ponto de vista da atuação federal: a saúde bucal (Brasil Sorridente), a atenção às urgências (Serviços de Atendimento Móvel de Urgência) e a assistência farmacêutica (Farmácia Popular) $^{77}$ (MACHADO el al, 2011). O principal objetivo foi a expansão do acesso. Dentre as mudanças incrementais na política de saúde, as autoras também apontam as iniciativas de articulação da saúde com os demais ministérios e políticas sociais, incluindo a saúde no debate do novo modelo de desenvolvimento do país.

Permaneceu o incentivo à atenção primária, priorizando sua expansão nas regiões mais ricas e adensadas do país (Sul e Sudeste) e nos municípios maiores (cidades médias e metrópoles) (VIANA \& SILVA, 2012). Também houve debate sobre a flexibilização do modelo original do Programa Saúde da Família como tentativa de melhor adequação às diferentes realidades municipais, contudo, sem maior êxito (CASTRO \& MACHADO, 2012).

A unificação dos programas de transferência de renda no Programa Bolsa Família, com inovações gerenciais e estímulo de articulação com outras políticas públicas evidenciou a prioridade dada às políticas focalizadas. A ampliação do

\footnotetext{
${ }^{77}$ De acordo com as autoras, a saúde bucal e a atenção às urgências foram elaboradas no governo anterior, porém, obtiveram avanços importantes com os investimentos federais em serviços odontológicos especializados e o destaque dado ao Serviço de Atendimento Móvel de Urgência (SAMU). O Programa Farmácia Popular trouxe maiores inovações, ao expandir a oferta gratuita de medicamentos no sistema público, desde aqueles de atenção primária até os de alto custo, e introduzir o copagamento Estado-usuário na compra dos medicamentos. As autoras ressaltam que a saúde bucal e a assistência farmacêutica tradicionalmente apresentam grande peso dos gastos privados, contudo, o Brasil Sorridente resultou na expansão da oferta pública e gratuita de serviços e a Farmácia Popular resultou na expansão da oferta pública e privada.
} 
Programa Bolsa Família e de outras políticas voltadas para o combate à pobreza e às desigualdades sociais e regionais, assim como, a política de emprego e de aumento do salário mínimo repercutiram no crescimento maior da renda e do consumo dos mais pobres e das regiões mais pobres, em relação aos mais ricos e às regiões mais ricas do país (NERI, 2011), refletindo nas condições de vida e de saúde da população (VIANA \& SILVA, 2012).

No primeiro Governo Lula, enfatizou-se a implementação gradativa do SUS, através da busca de ampliação do acesso, garantia da integralidade da assistência, integração das políticas nacionais, articulação com outras políticas sociais e elaboração de planos de ação focalizados em grupos específicos, tais como: saúde da mulher, saúde da criança e do adolescente, saúde do idoso e saúde do trabalhador (MENICUCCI, 2011). Também existiu a preocupação em integrar as ações da política nacional de saúde, sobretudo de atenção básica com os níveis mais especializados de atenção, dar destaque aos recursos humanos, ao desenvolvimento científico tecnológico e priorizar a gestão democrática, a partir da reorganização do Ministério da Saúde (TEIXEIRA E PAIM, 2005). Os autores destacam ainda o processo participativo de construção do Plano Plurianual 2004-2007, que contou com a colaboração de trabalhadores, colegiados da saúde e o Conselho Nacional de Saúde, e o compromisso com o controle social através da realização das Conferências Nacionais de Saúde, de Saúde Bucal e de Ciência, Tecnologia e Inovação em Saúde.

A execução do orçamento federal da saúde oscilou entre 2003 e 2005, sem grande variação quanto à porcentagem do PIB, apresentando um aumento progressivo dos gastos com ações e serviços a partir de 2006 e crescimento das transferências federais diretas para estados e municípios, a partir de 2003 (MACHADO, 2012). O Pacto pela Saúde e a criação dos grandes blocos de financiamento, segundo nível de atenção à saúde, tipo de serviço, programas e funções, impulsionaram o aumento das transferências federais para as instâncias subnacionais, continuando a regulação federal através das condicionalidades e vinculações das transferências a programas nacionais específicos (MACHADO, 2012). 
A publicação do Pacto pela Saúde teve como objetivo principal "promover inovações nos processos e instrumentos de gestão", estabelecendo compromissos, indicadores e metas sanitárias para os três entes federados, mobilizando a sociedade para a ampliação dos recursos financeiros (regulamentação da Emenda Constitucional $\mathrm{n}^{\circ} 29$ de $2000^{78}$ ), definindo as diretrizes e responsabilidades dos entes federados, fortalecendo as relações intergovernamentais cooperativas e consolidando as transferências federais em blocos de gestão, para diminuir a fragmentação do financiamento e aumentar a autonomia de gestão dos recursos pelos entes (MENICUCCI, 2011, p.525).

Destaca-se nessa fase a revalorização do papel do Estado na condução de um planejamento nacional integrado e participativo, compreendido como um "processo técnico-político e social, que requer o envolvimento de vários atores" (MACHADO et al., 2010, p.2381). Diferentemente de gestões anteriores que se basearam em agendas, quadros de metas, planos anuais e projetos temáticos, o Ministério elaborou em 2003 um Plano Nacional de Saúde para firmar o compromisso do gestor federal com a saúde, dar visibilidade e articular as prioridades nacionais e orientar os acordos entre os gestores (MACHADO et al., 2010). A orientação predominante no planejamento e gestão de saúde nessa fase foi a democrático-participativa e a gerencialista, com definição de compromissos, metas, programação financeira e contratualização (MACHADO, 2012).

Antes da publicação das novas diretrizes de regionalização do SUS (Pacto pela Saúde), a “questão regional” se expressou na política federal de saúde através da

\footnotetext{
78 A Emenda Constitucional no 29 aprovada em 2000, assegurou uma base estável de recursos mínimos para o financiamento das ações e serviços públicos de saúde. A EC 29 foi regulamentada pela Lei $n^{\circ} 141$ de 13 de janeiro de 2012, que dispõe sobre os valores mínimos a serem aplicados anualmente pela União, Estados, Distrito Federal e Municípios em ações e serviços públicos de saúde; estabelece os critérios de rateio dos recursos de transferências para a saúde e as normas de fiscalização, avaliação e controle das despesas com saúde nas três esferas de governo. Recursos mínimos destinados às ações e serviços públicos de saúde: (i) União: aplicará o montante correspondente ao valor empenhado no exercício financeiro anterior acrescido de, no mínimo, o percentual correspondente à variação nominal do Produto Interno Bruto (PIB), sem possibilidade de redução do montante de recursos em caso de variação negativa do PIB; (ii) Estados e Distrito Federal: aplicarão no mínimo 12\% (doze por cento) da arrecadação dos impostos a que se refere o art. 155 e dos recursos de que tratam o art. 157, a alínea "a" do inciso I e o inciso II do caput do art. 159, todos da Constituição Federal, deduzidas as parcelas que forem transferidas aos respectivos Municípios; (iii) Municípios: aplicarão no mínimo $15 \%$ (quinze por cento) da arrecadação dos impostos a que se refere o art. 156 e dos recursos de que tratam o art. 158 e a alínea "b" do inciso I do caput e o $§ 30$ do art. 159, todos da Constituição Federal.
} 
publicação do Plano Saúde Amazônia - PAS (BRASIL, 2005). Essa estratégia inédita teve como propósito criar um diálogo da política de saúde com outras políticas públicas no âmbito da Política Nacional de Desenvolvimento Regional (PNDR), em processo de elaboração e implementação. Contudo, segundo a avaliação do PAS realizada por Viana et al. (2007; 2011), para garantir coerência, sustentação e articulação da política com outras no nível federal e nos estados, como estratégia de enfrentamento das desigualdades em saúde, o Ministério da Saúde deveria ter, dentre outras coisas, formulado políticas diferenciadas considerando a diversidade de situações geográficas e de saúde existentes na Amazônia Legal, o que não ocorreu. O nível federal não logrou elaborar uma visão sobre a dimensão territorial dos desafios de saúde na região, mantendo a lógica tradicional de indução vertical e foco nas redes assistenciais (BRASIL, 2005). Outras iniciativas direcionadas para regiões específicas (SIS-Fronteiras ${ }^{79}$ e Ride- $\mathrm{DF}^{80}$ ) não chegaram a fortalecer a lógica territorial na formulação e articulação da política de saúde, com escassez de estratégias e instrumentos para redução das desigualdades sociais e regionais (GADELHA et al., 2011).

O Pacto pela Saúde ${ }^{81}$ (BRASIL, 2006) surgiu da necessidade de fomentar a cooperação intergovernamental para avançar na universalização da saúde em um contexto territorial complexo - tanto pela divisão tripartite do poder, quanto pela diversidade de situações sanitárias existentes. O Pacto trouxe novas diretrizes da

\footnotetext{
79 "Instituído pela Portaria GM 1.120/05, o Sistema Integrado de Saúde das Fronteiras (SIS-Fronteira) é um Projeto da Secretaria de Atenção à Saúde do Ministério da Saúde voltado para a integração de ações e serviços de saúde na região fronteiriça do Brasil. O SIS-Fronteira contribui para o fortalecimento dos sistemas locais de saúde dos municípios situados na fronteira do país, além de ser uma importante estratégia para uma futura integração entre os países da América Latina" (Ministério da Saúde).

${ }^{80}$ A Região Integrada de Desenvolvimento do Distrito Federal e Entorno -Ride/DF- foi criada pela Lei Complementar $\mathrm{n}^{\circ} 94$ de 19 de Fevereiro de 1998, para enfrentar os problemas sociais e urbanos resultantes do rápido processo de crescimento populacional da Região do Distrito Federal. Na RideDF foi implantada a primeira experiência de constituição de um Colegiado de Gestão Regional Interestadual no Pacto pela Saúde. (Fonte: Guimarães L, Silva MDF, Fraga LO, Silva MA, Goulart FAA. Colegiado de Gestão Regional Interestadual: a experiência Ride-DF. Disponível em: www.saude.gov.br/dad).

${ }^{81}$ A Portaria $\mathrm{n}^{\circ}$. 399/GM de 22 de fevereiro de 2006 divulgou o Pacto pela Saúde 2006 e aprovou as Diretrizes Operacionais do Referido Pacto, que tem três componentes principais: o Pacto pela Vida, o Pacto em Defesa do SUS e o Pacto de Gestão do Sistema Único de Saúde (SUS). Esse último componente constata as iniquidades regionais do Brasil e afirma que "mais do que definir diretrizes nacionais é necessário avançar na regionalização e descentralização do SUS, a partir de uma unidade de princípios e uma diversidade operativa que respeite as singularidades regionais" (Portaria $\mathrm{n}^{\circ}$. $399 / \mathrm{GM})$.
} 
regionalização do SUS, com objetivo de diminuição das desigualdades regionais, respeito às diversidades regionais e fortalecimento do papel dos estados no planejamento regional e da coordenação intergovernamental no âmbito das regiões de saúde.

O Pacto trouxe uma nova definição de região de saúde:

Regiões de saúde - recortes territoriais inseridos em espaços geográficos contínuos. Identificá-los é responsabilidade dos gestores municipais e estaduais, tendo como base a existência de identidades culturais, econômicas e sociais, assim como de redes nas áreas de comunicação, infraestrutura, transportes e saúde. Nessas regiões, as ações e serviços devem ser organizados com o objetivo de atender às demandas das populações dos municípios a elas vinculados, garantindo o acesso, a eqüidade e a integralidade do cuidado com a saúde local. Para tanto, deve estar garantido o desenvolvimento da atenção básica da assistência e parte da média complexidade, assim como as ações básicas de vigilância em saúde. As Regiões de Saúde podem assumir diferentes desenhos, desde que adequados às diversidades locais, mesmo que não acompanhando as divisões administrativas regionais já utilizadas por alguns estados na organização de seus trabalhos. A delimitação das Regiões de Saúde não pode ser vista, portanto, como um processo meramente administrativo. Para que seja eficaz e efetiva, deve levar em conta todos os fatores envolvidos, viabilizando dessa forma o desenvolvimento de uma "regionalização viva" (BRASIL MS, 2006, p.23, grifo nosso).

Os critérios para a delimitação das regiões passam a englobar as identidades culturais, econômicas e sociais, as características epidemiológicas, a existência de redes de comunicação e transporte, além da infraestrutura assistencial da saúde. Neste caso, o Pacto pela Saúde não determina um rol mínimo de ações a serem executadas pela região de saúde, mas prevê as ações de Atenção Básica, parte da média complexidade e ações básicas de vigilância em saúde. A demanda de saúde da população passa a ser citada como critério importante de regionalização, além da capacidade da oferta de serviços. Outro critério fundamental passa a ser a existência de cooperação intergovernamental entre o estado e os municípios que compõem a região de saúde.

Pode-se afirmar que o Pacto pela Saúde inicia uma nova fase da regionalização - a "regionalização viva" - ao procurar trazer os conteúdos do território para dentro da lógica do sistema de saúde, buscando maior coerência na sua organização (VIANA et al, 2008). Representa também uma inflexão na forma de 
atuação do governo federal e avança no estabelecimento de compromissos regionais de gestão, definindo responsabilidades, objetivos e metas associados aos indicadores de monitoramento (MACHADO et al., 2010). Ao mesmo tempo, o Pacto tornou o processo de regionalização mais complexo do ponto de vista institucional e político e associou-o "a uma perspectiva mais ampla e integrada de transformação sócioeconômica e de redução das desigualdades regionais, sendo amparada pela expansão dos investimentos públicos federal e estadual” (LIMA \& VIANA, 2011, p.49)

A grande inovação introduzida pelo Pacto foi a obrigatoriedade de criação, nas regiões de saúde, da instância de negociação intergovernamental denominada Colegiado de Gestão Regional (CGR). O documento se preocupou em não reduzir a regionalização a um "conjunto de normas complexas que se sobreponham a um efetivo processo político" (BRASIL, 2006, p.09). Sendo assim, os CGRs constituíam-se como "espaços de permanente pactuação e co-gestão solidária", compostos por todos os gestores municipais de saúde que integram a região de saúde e por representantes da gestão estadual (e da gestão federal, no caso das regiões em áreas de fronteiras internacionais). Cada região deveria ter um CGR e "os desenhos e formas de organização dos CGRs devem espelhar as diversas possibilidades de conformação das Regiões de Saúde” (BRASIL, 2006b, p.35).

Dentre as ações que deveriam compor as agendas dos CGRs, destacam-se: fazer a identificação e o reconhecimento das Regiões de Saúde; adotar processos dinâmicos no planejamento regional; atualizar e acompanhar a Programação Pactuada Integrada (PPI) de atenção à saúde; elaborar o desenho do processo regulatório, definindo claramente os fluxos e protocolos necessários; priorizar as linhas de investimentos; estimular estratégias que contribuam para a qualificação do controle social; apoiar processos de qualificação da gestão do trabalho e da educação em saúde; construir estratégias para que sejam alcançadas as metas priorizadas no Pacto pela Vida, com a definição, se necessário, de outras prioridades loco-regionais; constituir processos dinâmicos para a avaliação e o monitoramento regional; aprimorar os mecanismos de regulação da assistência à saúde; fortalecer as iniciativas e ações contidas no Pacto em defesa do SUS; coordenar a agenda e o trabalho da(s) Câmara(s) Técnica(s) Permanente(s); dentre outras. (BRASIL, 2006b, pp.35-37). 
O PDR, a PPI e o PDI foram mantidos, ainda que atualizados por portarias ministeriais e pelas oficinas regionais realizadas nos estados, conforme as novas regras do Pacto. Foram propostos três novos instrumentos de planejamento regional em relação à Noas: (i) o Termo de Compromisso de Gestão, que substituiu o processo de habilitação, como um documento de formalização do Pacto pela Vida e de Gestão, assinado pelos estados e municípios para fins de repasse financeiro federal, conforme objetivos e metas definidos; (ii) os indicadores de monitoramento do Termo de Compromisso de Gestão; e (iii) os grandes blocos de financiamento, agregando o orçamento às prioridades políticas definidas no Pacto pela Vida e de Gestão. A principal mudança ocorreu em relação aos blocos de financiamento e à elaboração de uma lista de indicadores de monitoramento e avaliação da implantação do Pacto pela Saúde nos estados, distrito federal e municípios.

Os indicadores foram pactuados na Comissão Intergestores Tripartite e nas CIBs e os resultados das metas alcançadas foram divulgados em forma de relatório (estaduais e municipais), no sistema informatizado do Ministério da Saúde denominado SISPACTO. Os indicadores nacionais serviam de parâmetro para outros indicadores acordados nos estados e municípios e seguiram as prioridades ${ }^{82}$ definidas pelo Pacto pela Vida, revisadas a cada dois anos pela CIT. Contudo, não foram elaborados relatórios regionais, dificultando uma análise mais integrada e consolidada dos impactos desses indicadores por região de saúde.

A adesão ao Pacto foi realizada através do Termo de Compromisso de Gestão, que deveria ser assinado pelos estados, distrito federal e municípios e compreendia as "responsabilidades sanitárias e atribuições do respectivo gestor, as metas e objetivos do Pacto pela Vida, que definem as prioridades dos três gestores para o ano em curso e os indicadores de monitoramento" (Portaria ${ }^{\circ}$ 699/GM de 30 de março de 2006). O Termo deveria trazer como anexos: I - o termo de cooperação entre entes públicos; II - a declaração da CIB de comando único do sistema pelo

\footnotetext{
${ }^{82}$ Prioridades para o biênio 2010 - 2011: atenção à saúde do idoso; controle do câncer de colo de útero e de mama; redução da mortalidade infantil e materna; fortalecimento da capacidade de respostas às doenças emergentes e endemias, com ênfase na dengue, hanseníase, tuberculose, malária, influenza, hepatite e aids; promoção da saúde; fortalecimento da atenção básica; saúde do trabalhador; saúde mental; fortalecimento da capacidade de resposta do sistema de saúde às pessoas com deficiência; atenção integral às pessoas em situação ou risco de violência; e saúde do homem (Portaria $\mathrm{n}^{\circ} 2.669$, de 3 de novembro de 2009).
} 
gestor municipal; III - o termo do limite financeiro global do município, estado e DF; e IV - relatório dos indicadores de monitoramento. Os Termos de Compromisso de Gestão eram aprovados pelos Conselhos de Saúde, CIBs e homologados na CIT.

Uma das principais contribuições do Pacto pela Saúde foi a diminuição da fragmentação do sistema de financiamento federal da saúde ${ }^{83}$, a partir de sua reorganização em cinco grandes blocos: I - Atenção Básica; II - Atenção de Média e Alta Complexidade Ambulatorial e Hospitalar; III - Vigilância em Saúde; IV Assistência Farmacêutica; e V - Gestão do SUS (Portaria no 204/GM de 29 de janeiro de 2007). O repasse dos recursos passou a ocorrer conforme o nível de atenção à saúde, tipo de serviços, programas e funções (forma preponderante) (VIANA \& LIMA, 2011). Também foram incluídos novos critérios para o financiamento do bloco da Atenção Básica considerando as especificidades regionais, com vistas à diminuição das desigualdades em saúde, para alocação de recursos compensatórios correspondentes a 5\% do valor mínimo do Piso de Atenção Básica (PAB Fixo) multiplicado pela população do Estado (Portaria $N^{\circ}$ 204, de 29 de janeiro de 2007).

A liberação dos incentivos financeiros federais do Pacto pela Saúde, para estados, distrito federal e municípios, dependia da assinatura do Termo de Compromisso de Gestão e a execução de parte das metas nele expressas. Especificamente no caso do Bloco V e do componente para a Qualificação da Gestão do $\mathrm{SUS}^{84}$, as transferências federais estavam totalmente condicionadas à adesão ao Pacto pela Saúde.

\footnotetext{
${ }^{83}$ Antes do Pacto pela Saúde, o financiamento ocorria através do repasse direto ao prestador segundo produção aprovada e transferências segmentadas em várias parcelas ("projectgrants") por nível de atenção à saúde, tipo de serviço e programas, incluindo a definição de referências intermunicipais (forma preponderante) (VIANA \& LIMA, 2011).

${ }^{84}$ Art. 30. O Componente para a Qualificação da Gestão do SUS [Bloco V] apoiará as ações de: I Regulação, Controle, Avaliação, Auditoria e Monitoramento; II - Planejamento e Orçamento; III Programação; IV - Regionalização; V - Gestão do Trabalho; VI - Educação em Saúde; VII - Incentivo à Participação e Controle Social; VIII - Informação e Informática em Saúde; IX - Estruturação de serviços e organização de ações de assistência farmacêutica; e X - outros que vierem a ser instituídos por meio de ato normativo específico. $\S 1^{\circ}$ A transferência dos recursos no âmbito deste Componente dar-se-á mediante a adesão ao Pacto pela Saúde, por meio da assinatura do Termo de Compromisso de Gestão e respeitados os critérios estabelecidos em ato normativo específico e no Anexo II a esta Portaria, com incentivo específico para cada ação que integra o Componente. (Portaria $n^{\circ}$ 204/GM de 29 de janeiro de 2007)
} 
Do ponto de vista jurídico, o Termo de Cooperação entre Entes Públicos ${ }^{85}$ adotado na proposta de regionalização, serviu para formalizar a relação entre os entes federados "quando unidades públicas prestadoras de serviços, situadas no território de um Município, estão sob a gerência de determinada Unidade da Federação e gestão de outra" (Portaria n ${ }^{\circ} 161$, de 21 de Janeiro de 2010). O Termo formalizava as responsabilidades dos gestores no território frente aos serviços de saúde ofertados (próprios, conveniados ou contratados) e contemplava a definição da oferta e fluxos de serviços, metas qualitativas e quantitativas e mecanismos de acompanhamento e avaliação, sendo que os recursos de custeio transferidos deveriam ser condicionados pelo cumprimento das metas pactuadas e não pela produção de serviços. Apesar disso, Pacto não superou a falta de "mecanismos constitucionais ou legislação ordinária que possibilitem a cooperação entre os entes federados, com exceção para a recente lei que regulamenta os consórcios públicos" (NASCIMENTO, 2007, p.202).

A nova diretriz de regionalização procurou relacionar a Programação Pactuada Integrada de assistência à saúde (PPI) à nova política de regulação dos complexos reguladores (BRASIL, 2006c) e aos indicadores de monitoramento do Pacto pela Vida. O objetivo foi tentar flexibilizar a PPI para torná-la mais próxima e coerente com as necessidades regionais em saúde e os níveis de complexidade tecnológica, além de superar os limites da programação para a estruturação das redes assistenciais e das regiões de saúde (BRASIL, 2006b).

A revisão da PPI priorizou a estimativa mais detalhada das necessidades de saúde, considerando uma série de indicadores, incluindo aqueles do Pacto pela Vida, e as metas estabelecidas nos termos de compromisso de gestão (BRASIL, 2006b). Para dimensionar a regionalização e as redes assistenciais, o financiamento na programação incluiu modalidades sob-responsabilidade dos orçamentos estaduais e

\footnotetext{
85 “Art. $3^{\circ} \mathrm{O}$ Termo de Cooperação entre Entes Públicos, cujo conteúdo será pactuado entre Ministério da Saúde, Conass e Conasems em portaria específica, é destinado à formalização da relação entre gestores quando unidades públicas prestadoras de serviço, situadas no território de um município, estão sob gerência de determinada esfera administrativa e gestão de outra.

$\S 1^{\circ} \mathrm{O}$ Termo de Cooperação entre Entes Públicos deve conter as metas e um plano operativo do acordo.

$\S 2^{\circ}$ As unidades públicas prestadoras de serviço devem, preferencialmente, receber os recursos de custeio correspondentes à realização das metas pactuadas no plano operativo e não por produção.

$\S 3^{\circ}$ A transferência de recursos, objeto do Termo de Cooperação entre Entes Públicos, deverá ser feita conforme pactuação" (Portaria no 699/GM, de 30 de março de 2006).

A Portaria n 161, de 21 de Janeiro de 2010 versa sobre o Termo de Cooperação entre Entes Públicos.
} 
municipais, entretanto, não abarcou a totalidade dos recursos dificultando a visualização da distribuição espacial do orçamento estadual por região de saúde.

A Noas já previa a implantação de complexos reguladores, "entendidos como uma ou mais centrais de regulação", mas o Pacto pela Saúde definiu a regulação como uma diretriz, que "configura uma linha de financiamento de custeio específico através do bloco de financiamento da Gestão", além de conceituar as estruturas regulatórias, listar os princípios orientadores, definir metas e explicitar as responsabilidades de cada esfera governamental (BRASIL, 2006c). Apesar disso, nota-se a fragilidade da regulação em saúde em praticamente todos os estados (ALBUQUERQUE et al., 2011).

As Comissões Intergestores Bipartite continuaram sendo os espaços privilegiados para negociação e pactuação dos Termos de Cooperação entre Entes Públicos, assim como, dos instrumentos de planejamento regional: PPIs, PDRs e PDIs.

Nessa fase, a efetivação e institucionalização do processo de regionalização do SUS nos estados passaram a depender de bases técnica e política bem articuladas (ALBUQUERQUE et al., 2011). Ainda que os estados continuassem como os principais responsáveis pela coordenação dessa estratégia, todos os municípios tornam-se corresponsáveis pela construção do processo.

Os fóruns de coordenação federativa foram valorizados e ganharam maior peso técnico e político. Destacam-se, nesse sentido, as Comissões Intergestores Bipartite (CIBs) que, em sua maioria, conseguiram alcançar maior diversidade e aderência à realidade estadual dos temas debatidos, "realizando esforços para adaptação de proposições nacionais ao contexto estadual", facilitando, inclusive, a indução e consolidação do processo de regionalização (MACHADO et al, 2011b, p.183). Na maioria das CIBs, os temas foram definidos de forma compartilhada entre estados e municípios, a partir de relações de poder relativamente equilibradas entre as esferas de governo e participação ativa dos municípios (MACHADO et al, 2011b).

O Pacto pela Saúde foi muito bem recebido pelos gestores do SUS, sobretudo, quanto à proposta de regionalização da saúde (VIANA \& LIMA, 2011) porque, dentre outras coisas, gerou maior estímulo à participação e integração entre 
os municípios (ASSIS et al., 2009) e representou um engenhoso modelo para induzir o federalismo cooperativo (DOURADO \& ELIAS, 2011).

Os CGRs possibilitam preencher aquilo que chamamos de "vazio" de governança regional no SUS*. Eles são espaços privilegiados para a identificação de problemas, a definição de prioridades e de soluções para a organização da rede assistencial, bem como para a formalização de novos modelos de relacionamento e regulação de provedores públicos e privados. Dessa forma, tendem a favorecer a constituição de objetivos compartilhados e o estabelecimento de uma lógica voltada para as necessidades regionais de saúde na provisão dos serviços (visão regional). (LIMA \& VIANA, 2011, p.57) [*nota das autoras: não se quer com isso desconsiderar o importante papel desempenhado pelas Comissões Intergestores Bipartites regionais instituídas em alguns estados, como por exemplo, MG, RS e MT]

Apesar do avanço em relação ao foco político da regionalização, observa-se uma "desarticulação entre os processos de planejamento e de pactuação intergovernamental”, pois o Pacto pela Saúde não trouxe mudanças nos instrumentos de planejamento regional do SUS, pelo contrário, tais instrumentos e recursos foram pouco valorizados no documento (MACHADO et al., 2010; VIANA \& LIMA, 2011; LIMA \& QUEIROZ, 2012, p.248). Essa desarticulação prejudicou inclusive o poder de indução federal, "que não se restringe à coordenação de um processo 'de base local e ascendente', uma vez que existem atributos próprios do planejamento em cada âmbito territorial" (MACHADO et al., p.2376). Soma-se a isso a falta de relações claras entre o processo de regionalização e de assinatura dos Termos de Compromisso de Gestão, visto que isto pode ocorrer sem que a regionalização esteja fortalecida, e a falta de estrutura e recursos dos CGRs para permitir o desenvolvimento de parcerias e resolução de conflitos intergovernamentais (LIMA \& VIANA, 2011).

A diretriz de regionalização do Pacto pela Saúde procurou conversar com novas e velhas regionalizações em vigor: regiões metropolitanas, regiões de fronteira, territórios da cidadania, consórcios de saúde, Regiões Integradas de Desenvolvimento (Ride), áreas indígenas, etc. Contudo, não houve progresso na elaboração de estratégias e instrumentos de planejamento, regulação e financiamento para os diferentes recortes e suas especificidades regionais (LIMA \& QUEIROZ, 2012). 
A estruturação da "regionalização viva" dependia das redes e fluxos assistenciais existentes, mas, sobretudo, das negociações intergovernamentais coordenadas e cooperativas. Apesar de fortalecer o papel dos estados e dos municípios no planejamento regional, com a criação dos colegiados de gestão regional, o Pacto não alterou significativamente os instrumentos de planejamento, à exceção dos blocos de financiamento e dos indicadores de monitoramento e avaliação, limitando maiores avanços na gestão compartilhada do SUS. A dimensão territorial no planejamento em saúde ganhou uma nova percepção, menos normativa e mais política, também voltada para a diversidade de configuração das redes assistenciais nos lugares. Contudo, o nível federal não conseguiu elaborar uma visão mais estratégia sobre a dimensão territorial das desigualdades de organização, funcionamento e uso do SUS e da universalização da saúde no Brasil (VIANA et al., 2007, 2008, 2011; GADELHA et al., 2011; LIMA \& QUEIROZ, 2012; ALBUQUERQUE, 2012).

As diretrizes da "regionalização viva" possibilitaram a configuração de regiões de saúde muito diversas quanto ao número de municípios envolvidos, à capacidade de oferta de ações e serviços assistenciais, às características socioeconômicas, políticas e territoriais (dados do Ministério da Saúde; VIANA \& LIMA, 2011; DUARTE et al, 2013).

A grande heterogeneidade entre as regiões de saúde evidenciou que o processo nos estados seguiu racionalidades e critérios diversificados, conforme as realidades e acordos políticos locais, e que houve baixa capacidade de indução federal sobre as especificidades desse processo. Essa situação despertou uma preocupação no nível federal sobre como equilibrar os fundamentos técnicos e políticos da regionalização nos estados de forma a garantir maior poder de indução sobre as mudanças no sistema, a partir das regiões de saúde constituídas, e potencializar essa estratégia para alcançar maior efetividade na universalização da saúde. A publicação da Portaria 4.279 de 2010, referente à estruturação das redes de atenção à saúde no Brasil, também reforçou a necessidade de mudanças nas diretrizes de regionalização do SUS.

Pode-se afirmar que a "regionalização viva" representou uma fase de transição para a "regionalização contratualizada", uma vez que promoveu avanços 
fundamentais para o processo nos estados, notadamente a implantação das instâncias colegiadas regionais, mas não reformulou os instrumentos de planejamento e gestão regionais.

Esse descompasso entre avanços técnicos e políticos nas diretrizes de regionalização do SUS e a emergência, a partir de 2007, de políticas voltadas para a estruturação de redes temáticas de atenção à saúde demandaram mudanças importantes nas normas estabelecidas, resultando na nova fase da "regionalização contratualizada".

\subsection{A "regionalização contratualizada": Decreto no 7.508 (2011)}

Entre 2007 e 2010, a política de saúde permaneceu com uma orientação gerencialista, mas aproximou-se fortemente da agenda de desenvolvimento proposta no segundo Governo Lula (MACHADO et al., 2010).

O diálogo da política de saúde com a nova agenda de desenvolvimento, pautada pelo crescimento econômico, distribuição de renda e diminuição das desigualdades socioespaciais, ocorreu em duas frentes principais: (i) como setor intensivo em inovação científica e tecnológica (complexo econômico da saúde), que possibilita grande acumulação de capital; e (ii) como sistema público e universal de ações e serviços assistenciais, que deve garantir o direito à saúde e promover melhoria nas condições de vida e saúde da população (VIANA \& ELIAS, 2007).

O Programa Mais Saúde (BRASIL, 2007) (também chamado de "PAC da Saúde" em alusão ao Plano de Aceleração do Crescimento - PAC) marcou a entrada da política de saúde na agenda de desenvolvimento do país, centrando suas ações na ampliação do acesso, melhoria da gestão do SUS e no investimento no setor industrial ligado aos equipamentos médicos e hospitalares e à produção de medicamentos para aumento da geração de riqueza no país.

A saúde possui, assim, duas dimensões que se associam a uma nova aposta para o desenvolvimento do Brasil. É parte da política social e do sistema de proteção social e fonte de geração de riqueza para o País. O direito à saúde articula-se com um conjunto altamente dinâmico de atividades econômicas que podem se relacionar virtuosamente num 
padrão de desenvolvimento que busque o crescimento econômico e a equidade como objetivos complementares (BRASIL, 2007, p.5).

A política também enfatizou os determinantes sociais de saúde e a articulação com outras políticas públicas voltadas para o combate à pobreza e às desigualdades sociais e regionais (MENICUCCI, 2011). A ampliação do Programa Bolsa Família, a política de emprego e o aumento do salário mínimo repercutiram no crescimento proporcionalmente maior da renda e do consumo dos mais pobres e das regiões mais pobres, em relação aos mais ricos e às regiões mais ricas do país (NERI, 2011). De acordo com Menicucci (2011, p.528), a priorização de políticas de inclusão social, de habitação e saneamento "sugere uma busca da garantia do direito à saúde pela via de outras políticas públicas, que não apenas a garantia do acesso a ações e serviços de saúde". Por outro lado, a redução da desigualdade na distribuição da renda do trabalho e o aumento do contingente da classe trabalhadora não resultaram em maior politização na base da pirâmide social e a interpretação do surgimento de uma nova classe média gerou "apelo à orientação das políticas públicas para a perspectiva fundamentalmente mercantil", fortalecendo os sistemas privados de saúde, educação, assistência e previdência e as propagandas de desvalorização dos serviços públicos (POCHMANN, 2012, p.11).

No que se refere ao setor saúde como fonte de geração de riquezas, a prioridade foi dada ao complexo industrial da saúde, a partir de ações articuladas com outros ministérios e com o BNDES no âmbito da política industrial, para fortalecer a capacidade produtiva e de inovação das empresas e produtores públicos e privados nacionais, utilizando o uso do poder de compra do Estado, incentivando a inovação, a pesquisa científica, e redefinindo o marco regulatório, sob a justificativa de aproximar os centros de pesquisa com indústrias nacionais e com as necessidades do Sistema Único de Saúde e reduzir a vulnerabilidade da política social brasileira em relação às oscilações dos produtos no mercado internacional. O Programa Mais Saúde introduziu ainda dois eixos novos na política: o da promoção da saúde e o da cooperação internacional.

No que se refere à qualificação da gestão, o foco do Programa residiu na ampliação das responsabilidades das três esferas de governo, visando melhorias nos "resultados da saúde", e o estabelecimento de novos modelos de gestão, a exemplo 
das fundações públicas, para permitir às instituições de saúde operar "com maior eficiência e qualidade, pactuando compromissos com resultados".

A ampliação do acesso na atenção básica focou a expansão da Estratégia Saúde da Família, com medidas específicas para a qualificação dos profissionais e criação dos Núcleos de Apoio à Saúde da Família (NASFs), do Programa Brasil Sorridente e do trabalho dos agentes comunitários de saúde, incluindo sua atuação no âmbito das escolas (MENICUCCI, 2011). Houve também preocupação com a melhoria no acesso aos serviços especializados e internações, através de novas formas de compra de serviços, com contratualização dos filantrópicos, do tratamento de hipertensão e diabetes e dos investimentos em Centros de Especialidades Odontológicas, em infraestrutura para duplicação da cobertura do SAMU e na implantação de complexos reguladores (MENICUCCI, 2011). O Programa Farmácia Popular se expandiu, a partir de 2006, com os convênios firmados com farmácias privadas, sobretudo nas regiões Sudeste e Sul (MACHADO et al., 2011).

O governo federal investiu em novos equipamentos, como os Centros de Atenção Psicossocial (CAPS) e as Unidades de Pronto Atendimento (UPAs), neste caso, procurando ampliar as portas de entrada do SUS, sobretudo em áreas de "vazios assistenciais", e agilizar os atendimentos de urgência e emergência de média e baixa complexidades (VIANA \& IBAÑEZ, 2010). Além disso, investiu na criação da Universidade Aberta do Sistema Único de Saúde - UNA-SUS, com a finalidade de atender às necessidades de capacitação e educação permanente dos trabalhadores do SUS, por meio da educação à distância.

Apesar do fim da CPMF em 2007, houve crescimento progressivo dos gastos federais em saúde, entre 2006 e 2009, em grande parte, como resultado do crescimento econômico do país ${ }^{86}$ (MACHADO, 2012). Contudo, observam-se baixos valores dos investimentos federais em relação aos grupos de despesa, limitando sua capacidade de induzir a diminuição das desigualdades em saúde no território nacional. Ainda que entre 2002 e 2009, a variação na execução orçamentária do Ministério da Saúde tenha apresentado um crescimento maior nas regiões Norte $(59,6 \%)$, Centro-Oeste $(55,4 \%)$ e Nordeste $(49,2 \%)$, a distribuição per capita mostra

\footnotetext{
86 “A exceção foi o ano de 2009, em que houve aumento da execução orçamentária do Ministério da Saúde apesar da queda do PIB, endossando o argumento do governo federal de adoção de políticas anticíclicas em face da crise econômica." (MACHADO, 2012, p.142).
} 
a concentração dos valores nas regiões Sul e Sudeste (MACHADO, 2012, p.133). Os investimentos federais tenderam a privilegiar, na escala macrorregional, as regiões mais carentes de oferta e cobertura assistenciais, sem representar, entretanto, uma mudança estrutural na quantidade e qualidade dos serviços nessas regiões (GADELHA et al., 2011). Além da insuficiência de recursos, outro problema apontado pelos autores é a falta de orientação estratégica desses investimentos macrorregionais, e mesmo de uma política de longo prazo de combate às desigualdades nessa escala, resultando na pulverização das ações e demonstrando uma visão fragmentada do território brasileiro. Soma-se a isso a crescente aprovação de emendas parlamentares da saúde, desvinculadas de um planejamento nacional de investimentos (BAPTISTA et al., 2011).

O Ministério da Saúde, através do adensamento das estratégias e instrumentos de planejamento, buscou fortalecer seu papel e dar direcionalidade à política (MACHADO et al, 2010). Contudo, houve limitações na elaboração de análises situacionais e incorporação da dimensão territorial para a formulação de políticas diferenciadas regionalmente, escassez de mecanismos de coordenação para lidar com a variedade de ações e metas, além da política de saúde "ocupar um lugar modesto" na agenda desenvolvimentista, resultando na não regulamentação da Emenda Constitucional no29 e no baixo enfrentamento de questões estruturais, como as distorções resultantes das relações público-privadas e das desigualdades em saúde (MACHADO et al, 2010, p.2381) A despolitização do debate sobre saúde na sociedade e no legislativo restringiu a discussão ao volume necessário de recursos financeiros a serem aplicados no SUS (MENICUCCI, 2011) e às demandas segmentadas por grupos de interesse (BAPTISTA et al., 2012).

Em dezembro de 2010, foi publicada a Portaria $n^{\circ} 4.279 / 10$ introduzindo na política nacional o conceito de redes de atenção à saúde e definindo as diretrizes para a estruturação das mesmas no âmbito das regiões de saúde. Havia uma preocupação de integrar ações e serviços em redes de atenção à saúde e recuperar o papel de indução do gestor federal através de um "vigoroso programa de investimento", além 
de priorizar as metas do Pacto pela Saúde, referentes aos problemas prioritários e programas específicos ${ }^{87}$.

Em 2011, durante o Governo Dilma Rousseff, a Emenda Constitucional nº29 foi regulamentada, possibilitando a definição do que é compreendido como "ações e serviços de saúde", para evitar o uso dos recursos em ações fora do setor, e mantendo percentual de recursos da União para a saúde, sem avanços na garantia de aumento dos recursos, adiando novamente a discussão sobre o financiamento (BAPTISTA et al., 2012).

No Governo Dilma, a política de saúde apareceu integrada no Programa de Aperfeiçoamento do SUS (PPA 2012-2015, Brasil, MP, 2011), com objetivo de universalidade, integralidade e equidade no acesso à saúde.

O foco na ampliação e qualificação do acesso, de forma a garantir, em tempo hábil, os atendimentos de qualidade e necessários à população, marcou o discurso ministerial. Algumas estratégias confirmam essa preocupação: as alterações na política de assistência farmacêutica, com a implantação do programa Saúde Não Tem Preço $^{88}$, no âmbito do Programa Farmácia Popular; a priorização de redes temáticas de atenção à saúde, como a Rede Cegonha para a saúde materno-infantil e a Rede de Urgência e Emergência; a elaboração de um Programa de Avaliação para Qualificação do SUS; a proposição do Programa Nacional de Melhoria do Acesso e da Qualidade da Atenção Básica (PMAQ-AB); e a regulamentação da Lei nº 8.080 de 1990 através do Decreto nº 7.508 de 2011 (Ipea, 2012).

Os investimentos em atenção básica continuaram priorizando o Programa Saúde da Família, a saúde bucal, as Unidades Básicas de Saúde e a qualificação profissional das equipes. Também houve intenção de expansão do Programa

87 "Priorizar em todas as medidas as metas do Pacto pela Saúde, referentes à saúde do idoso, ao controle do câncer de colo de útero e de mama, à redução da mortalidade infantil e materna, ao fortalecimento da capacidade de resposta às emergências de saúde pública, de relevância nacional para a redução da ocorrência de doenças, envolvendo o controle de enfermidades como dengue, hanseníase, tuberculose, malária e influenza. Implementar ações integradas para o atendimento a populações em situações de risco, como as indígenas, as quilombolas e de assentamentos" (BRASIL, 2007, p.25).

${ }^{88}$ O Programa "Saúde Não Tem Preço" disponibiliza gratuitamente medicamentos para o tratamento da hipertensão e diabetes na rede credenciada no "Aqui tem Farmácia Popular". Essa ação resulta de um acordo entre o Ministério da Saúde e entidades da indústria e comércio, beneficiando 33 milhões de hipertensos e 7,5 de diabéticos, além de diminuir o comprometimento da renda dos mais pobres com a compra de medicamentos (Fonte: Ministério da Saúde). 
Farmácia Popular, sobretudo nas regiões mapeadas pela política de combate à extrema pobreza.

$\mathrm{Na}$ atenção de média e alta complexidade permaneceu a perspectiva de ampliação da rede assistencial, através de investimentos públicos e habilitação de unidades. Verifica-se a ênfase na estruturação e extensão das redes temáticas de atenção à saúde (oncologia, cardiovascular, materno-infantil, saúde mental e de urgência e emergência) como uma das estratégias prioritárias para a expansão dos investimentos públicos.

$\mathrm{O}$ desenvolvimento produtivo e o investimento em atividades intensivas no uso de ciência e tecnologia são priorizados. No PPA 2012-2015, no âmbito do programa de desenvolvimento produtivo, destaca-se aquele direcionado ao fortalecimento do complexo produtivo industrial da saúde, que visa ampliar a produção nacional de fármacos, biofármacos, medicamentos, imunobiológicos, equipamentos e materiais de uso em saúde, sobretudo, daqueles de maior conteúdo tecnológico e considerados estratégicos para o SUS. O Programa Brasil Maior (política produtiva) e a Estratégia Nacional para a Ciência, Tecnologia e Inovação têm dentre suas áreas estratégicas e prioritárias atividades correspondentes ao complexo produtivo industrial da saúde.

A questão regional no planejamento em saúde continuou sendo valorizada e associou-se fortemente à necessidade de articulação intergovernamental, aliada à expansão dos investimentos públicos em equipamentos de saúde e programas direcionados ao combate à pobreza, com estímulo às parcerias público-privadas (VIANA \& SILVA, 2012). A proposta de integração das ações e serviços de saúde em redes temáticas de atenção à saúde, seguindo diferentes linhas de cuidado, ganhou centralidade no planejamento regional.

A coordenação federativa permaneceu como preocupação fundamental da política federal. Antigos e novos instrumentos foram utilizados para aperfeiçoar o modelo de gestão do sistema e garantir ampliação e qualidade no acesso aos serviços de saúde, a ampliação da capacidade regulatória do Estado, a gestão participativa e o financiamento estável do sistema (BRASIL MP, 2011, p.134). Dentre os instrumentos priorizados para induzir a gestão coordenada e cooperativa do SUS, 
destacam-se o Cartão Nacional de Saúde e os Contratos de Ação Pública em Saúde (Coaps).

A grande mudança na política nacional de saúde foi a regulamentação da Lei 8.080 de 1990 através do Decreto $n^{\circ} 7.508$ de 2011. Este documento e seus desdobramentos normativos resultaram numa importante reformulação do planejamento regional do SUS, dando início à fase da "regionalização contratualizada".

O Decreto $n^{\circ} 7.508 / 11$ determina a organização do Sistema Único de Saúde, o planejamento em saúde, a assistência à saúde e a articulação interfederativa (sic). Dentre os objetivos, estão: estabelecer o padrão de oferta de ações e serviços de saúde no SUS; proporcionar maior transparência na gestão do sistema; integrar as políticas de saúde e os instrumentos de planejamento no nível regional; fortalecer o controle social; e garantir a segurança jurídica nas relações intergovernamentais (VIANA \& SILVA, 2012).

O Decreto $\mathrm{n}^{\mathrm{o}} \quad 7.508 / 11$ e seus dispositivos introduziram mudanças relacionadas à definição de região de saúde, aos instrumentos de planejamento e aos mecanismos de articulação federativa, consolidando a região de saúde como recorte privilegiado para a indução e integração das políticas, expansão do financiamento, estruturação das redes temáticas e garantia da integralidade no acesso ao sistema.

$\mathrm{O}$ art. $2^{\circ}$ define:

Região de Saúde - espaço geográfico contínuo constituído por agrupamentos de Municípios limítrofes, delimitado a partir de identidades culturais, econômicas e sociais e de redes de comunicação e infraestrutura de transportes compartilhados, com a finalidade de integrar a organização, o planejamento e a execução de ações e serviços de saúde.

Mantendo a flexibilidade dos desenhos regionais e respeitando as diversidades territoriais e pactuações políticas, o Decreto $\mathrm{n}^{\circ} 7.508 / 11$ determina $o$ cumprimento de rol mínimo de ações e serviços na região de saúde, para garantir a integralidade do atendimento (Resolução CIT no 1, de 17/01/2012). Além disso, a região de saúde deve ser capaz de estruturar redes de atenção à saúde (Portaria ${ }^{\circ}$ 4.279/10) e ser solidária com outras regiões, garantindo aos cidadãos o acesso a todas as ações e serviços que constam da Relação Nacional de Ações e Serviços de Saúde 
(Renases) (Resolução CIT $n^{\circ}$ 2, de 17/01/2012) e da Relação Nacional de Medicamentos Essenciais (Rename) (Resolução no 3, de 29/09/2011).

Para concretizar a integração das ações e serviços de saúde nas regiões, o Decreto $n^{\circ}$ 7.508/11 introduziu o Contrato Organizativo da Ação Pública da Saúde (Coap), baseados na definição de regras e acordos jurídicos entre os entes federados nas regiões de saúde. No Coap devem estar discriminadas as responsabilidades organizativas, executivas, orçamentárias e avaliativas de cada ente federado para o cumprimento dos objetivos e metas definidos para uma dada região de saúde (Resolução CIT n ${ }^{\circ}$ 3, de 30/01/2012, BRASIL, 2012). Cada região terá um Coap, assinado pelos gestores das três esferas de governo, com prazo de vigência, preferencialmente, de quatro anos (Art. 18 da Resolução). Os primeiros contratos serão construídos com base nos objetivos da Política Nacional de Saúde e nos indicadores herdados do Pacto pela Saúde (BRASIL, 2011d).

O processo de planejamento ascendente e integrado do sistema, baseado nas problemáticas e necessidades $^{89}$ de saúde da população local e na discussão permanente da política de saúde e sua execução nas Comissões Intergestores - CIT, CIB e CIR, e o Mapa da Saúde servirão como subsídio ${ }^{90}$ para a construção dos Coaps regionais.

O mapa constitui-se um documento único que agrega informações produzidas e disponibilizadas pelos três níveis de governo e outras instituições públicas e privadas, abrangendo ${ }^{91}$ obrigatoriamente a descrição dos fixos (equipamentos,

\footnotetext{
89 “As necessidades de saúde da população são base para o planejamento e identificadas por meio de critérios epidemiológicos, demográficos, sócio-econômicos, culturais, cobertura de serviços, entre outros, como também, levando em consideração a escuta das comunidades" (Diretrizes do Planejamento Integrado. Comissão Intergestores Tripartite, Brasília: janeiro de 2012).

90 “A produção resultante do processo de planejamento da saúde integrado, realizado no âmbito da região de saúde, compõe o Contrato Organizativo da Ação Pública da Saúde (COAP)". (Diretrizes do Planejamento Integrado. Comissão Intergestores Tripartite, Brasília: janeiro de 2012).

${ }^{91}$ I. $\quad$ Estrutura do Sistema de Saúde:

a. Capacidade instalada existente pública (própria e privada complementar) e privada, evidenciando os estabelecimentos de saúde, serviços, equipamentos e profissionais;

b. Oferta e cobertura de ações e serviços de saúde mediante uso de indicadores construídos a partir de parâmetros reconhecidos e da produção das ações e serviços de saúde prestados, quando não existir parâmetros definidos.

II. Redes de atenção à saúde: contempla indicadores ou marcadores que permitam evidenciar a atenção básica como ordenadora da rede de atenção à saúde, além de indicadores afetos à implementação das redes prioritárias para o sistema: rede materno-infantil, a rede de atenção às urgências, a rede de atenção psicossocial, além de outras que venham a ser conformadas e identificadas como prioridade.
} 
tecnologias, especialidades, profissionais, redes) e fluxos assistenciais do SUS (serviço próprio e privado complementar) e da iniciativa privada, os investimentos públicos em saúde, os indicadores de desempenho do sistema e a produção científica e tecnológica ligada à assistência à saúde. O mapa da saúde deverá auxiliar a identificação das necessidades de saúde da população referentes às condições de vida e acesso aos serviços e também à definição de metas para vencer lacunas, excessos e o reordenamento dos fixos e fluxos assistenciais e dos investimentos financeiros (mapa de metas $^{92}$ ).

As Comissões Intergestores Regionais (CIRs) (nova denominação dada aos Colegiados de Gestão Regional, instituídos pelo Pacto pela Saúde) são responsáveis pela elaboração e negociação intergovernamental dos Coaps e pela coordenação das redes regionalizadas de atenção à saúde. A necessidade de consolidar a "rede interfederativa" no SUS (SANTOS E ANDRADE, 2007, 2008) por meio da criação de uma "força vinculante entre as esferas governamentais" (ANDRADE, 2012) está subjacente à proposta.

III. Condições sociossanitárias: evidenciada por meio de indicadores de nascimento, mortalidade, morbidade, dados sócio-econômicos e demográficos. Sistematiza também informações sobre a situação de saúde de grupos populacionais de maior vulnerabilidade, bem como informações relativas aos determinantes sociais da saúde. Guarda relação direta com o Indicador Nacional de Acesso e Qualidade, na medida em que reflete indicadores que o compõe.

IV. Fluxos de acesso: evidenciando o caminho e distância percorridos pelos usuários, constituindo os fluxos assistenciais, mediante a apuração de residência e ocorrência de eventos.

V. Recursos financeiros: explicita os recursos de investimentos e custeio das três esferas de governo que financiam o sistema.

VI. Gestão do trabalho e da educação na saúde: identifica a quantidade de trabalhadores de acordo com os serviços e redes temáticas; condições de trabalho, contemplando: jornada média de trabalho, jornada média de trabalho segundo quantidade de vínculos de trabalho, número médio e tipo de vínculos de trabalho e indicadores de saúde do trabalhador; formação e qualificação profissional e características dos centros formadores.

VII. Ciência, tecnologia, produção e inovação em saúde: apresenta a distribuição das instituições e suas capacidades e especialidades técnicas, públicas e privadas, de pesquisa, produção e inovação em saúde.

VIII. Gestão: evidencia indicadores relativos aos processos de regionalização, planejamento, regulação, participação e controle social, bem como informações afetas às pesquisas de satisfação dos usuários do SUS e o resultado do Indicador Nacional de Acesso e Qualidade.

(Diretrizes do Planejamento Integrado. Comissão Intergestores Tripartite, Brasília: janeiro de 2012).

92 "Com a definição das metas da saúde contratualizadas no COAP, é elaborado o Mapa de Metas, retrato da situação a ser buscada (imagem-objetivo) e que evidencia as metas de saúde a serem alcançadas dentro de um marco de tempo definido no referido contrato, no tocante à estrutura e produção de serviços de saúde." (Diretrizes do Planejamento Integrado. Comissão Intergestores Tripartite, Brasília: janeiro de 2012). 
Alguns dos principais dispositivos introduzidos pelo Decreto têm referência em duas experiências recentes de organização regional de sistemas universais de saúde: a do estado de Sergipe (Brasil) e a da Catalunha (Espanha), que serviu de inspiração para a primeira.

De acordo com o relatório sobre o processo de regionalização em Sergipe, produzido no âmbito da pesquisa Avaliação Nacional das Comissões Intergestores Bipartites (CIBs): As CIBs e os Modelos de Indução da Regionalização no SUS ${ }^{93}$ (VIANA \& LIMA, 2011), as estratégias e instrumentos previstos na reforma sanitária e gerencial $^{94}$ do estado incluíram a constituição de redes assistenciais interfederativas regionais e a contratualização entre os entes federativos, substituindo os termos de compromisso previstos no Pacto pela Saúde. Nesse processo, foram instituídos os Colegiados Interfederativos Regionais (CIRs). A regionalização em Sergipe objetivou estruturar redes assistenciais interfederativas para garantir o acesso dos usuários e obter o Padrão de Integralidade da Assistência à Saúde ${ }^{95}$. Cinco redes integraram a proposta: (1) rede de atenção básica/saúde da família; (2) rede de atenção ambulatorial especializada; (3) rede de atenção hospitalar; (4) rede de atenção de urgência e emergência/ SAMU; (5) rede de atenção Psicossocial. As redes foram conformadas a partir de um amplo diagnóstico, e processo de planejamento e programação de ações e serviços de saúde, que prevê a

\footnotetext{
${ }^{93}$ Pesquisa realizada entre 2007 e 2010. Coordenação geral: Ana Luiza d'Ávila Viana - Departamento de Medicina Preventiva da Faculdade de Medicina da Universidade de São Paulo (DMP/FM/USP). Subcoordenação: Luciana Dias de Lima - Departamento de Administração e Planejamento em Saúde da Escola Nacional de Saúde Pública Sergio Arouca da Fundação Oswaldo Cruz (DAPS/ENSP/FIOCRUZ). A pesquisa contou com ampla equipe de pesquisadores, envolvendo três instituições de pesquisa - Departamento de Medicina Preventiva da Faculdade de Medicina da Universidade de São Paulo, Escola Nacional de Saúde Pública Sergio Arouca da Fundação Oswaldo Cruz e Instituto de Saúde Coletiva da Universidade Federal do Mato Grosso. Financiamento: a pesquisa contou com recursos do Ministério da Saúde, em parceria com a Organização Panamericana de Saúde; do Conselho Nacional de Desenvolvimento Científico e Tecnológico (CNPq); da Fundação Carlos Chagas de Amparo à Pesquisa do Estado do Rio de Janeiro (FAPERJ); do PAPES/Fundação Oswaldo Cruz; e da Fundação Faculdade de Medicina da Universidade de São Paulo. A síntese dos resultados da pesquisa está disponível em:

http://bvsms.saude.gov.br/bvs/descentralizacao/cibs/relatorio_final.php e em Viana \& Lima (2011).

${ }^{94}$ Lei Estadual no 6.345 de 2008, dispõe sobre organização e funcionamento do Sistema Único de Saúde no Estado de Sergipe - SUS/SE, e dá outras providências.

${ }_{95}$ O Padrão de Integralidade da Assistência à Saúde em SE corresponde "a todas as ações e serviços públicos de saúde prestados à população usuária, e deverá ser sempre o mesmo em toda a rede de serviços do SUS, organizada de maneira regionalizada e hierarquizada, em nível de complexidade crescente". Estão estabelecidos como direito dos usuários todos aqueles relacionados aos princípios e diretrizes do SUS, bem como as ações e serviços previstos nas Tabelas de Procedimentos e Lista Oficial de Medicamentos.
} 
integração e articulação entre municípios, servindo de base para a constituição das redes interfederativas regionais e para o estabelecimento da contratualização entre os gestores.

A concepção da reforma sanitária e gerencial em Sergipe contou com o trabalho de técnicos da Secretaria Estadual de Saúde, principalmente para a elaboração do diagnóstico e planejamento das ações e serviços das redes interfederativas regionais. A Secretaria também contou com o apoio de consultores externos. Destaca-se a participação do Instituto de Direito Sanitário Aplicado, na elaboração das Leis de Sergipe e do Contrato de Ação Pública; do grupo de consultoria da Catalunha (Espanha), Consórcio Hospitalar da Catalunya $(\mathrm{CHC})^{96}$, na formulação do Padrão de Integralidade, do Mapa Sanitário e das estratégias de contratualização e monitoramento; da Fiocruz e Unifesp, no que se refere à gestão hospitalar e nos projetos de criação das Fundações Estatais. Nesse processo de reforma sanitária e gerencial, houve maior envolvimento do Poder Legislativo com a política de saúde, em função das diversas leis aprovadas desde 2007.

No processo de elaboração do Decreto $n^{\circ} 7.508$ de 2011 e da minuta do Coap, entre 2008 e 2011, Lenir Santos (Instituto de Direito Sanitário Aplicado) foi a principal consultora do Ministério da Saúde (CARVALHO, 2011; BRASIL, 2012; SANTOS, 2012). A ex-secretária adjunta de saúde de Sergipe Monica Sampaio, que participou da reforma sanitária e gerencial no estado, também foi convidada a integrar a equipe da Secretaria de Gestão Estratégica e Participativa (SGEP/MS), secretaria responsável pela condução da elaboração dos dispositivos do Decreto $\mathrm{n}^{\circ}$ 7.508. O grupo de consultores do Consórcio Hospitalar da Catalunya (CHC) foi chamado pelo Ministério da Saúde para colaborar na definição dos novos instrumentos de planejamento introduzidos pelo Decreto nº 7.508: o Mapa da Saúde, as redes de atenção à saúde segundo linhas de cuidado, o Coap e a Relação Nacional de Ações e Serviços de Saúde (Renases). Da experiência Catală ${ }^{97}$ foram observadas as seguintes ferramentas estratégicas de planejamento e gestão do sistema: a carteira de serviços (cobertura, cobertos e efetividade), a compra e contratualização de

96 Agência Sergipe de Notícias. Saúde estuda convênio com o Consórcio Hospitalar da Catalunya. Aracaju, 02 de Outubro de 2008. (http://www.agencia.se.gov.br/noticias/leitura/materia:9413).

${ }^{97}$ Informações e análises sobre as reformas e o funcionamento do sistema de saúde catalão podem ser obtidas em: Departamento de Salud de Cataluña (http://www.gencat.cat/temes/cas/salut.htm); Belenes (2003); Villalbí et al. (2006); Guimarães \& Freire (2007); Silva (2007). 
serviços, o modelo de atenção (focalizando a atenção básica) e de organização das redes de serviços por linhas de cuidado (objetivando eficiência, continuidade, integração e coordenação), o planejamento com mapa sanitário (estabelecendo diretrizes e linhas estratégicas de ação), os recursos necessários (definidos pelo poder legislativo), o monitoramento e avaliação dos contratos (disponibilidade de recursos estruturais, financeiros, tecnológicos, profissionais e tendências futuras). O foco está nos resultados e nas necessidades de saúde da população.

O Decreto $\mathrm{n}^{\circ} 7.508$ representa um progresso normativo para as diretrizes de regionalização do SUS, em comparação à Noas e ao Pacto pela Saúde (Quadro 3), possibilitando avanços técnicos, políticos, normativos e informacionais para o processo de regionalização nos estados.

Em relação à definição de região de saúde, o Pacto pela Saúde representou um progresso em relação à Noas, ao condicionar o recorte regional à existência de um colegiado gestor agregando todos os municípios e o representante estadual e enfatizando a necessidade de cooperação e coordenação intergovernamental para a organização regional do sistema. Além disso, o Pacto tornou livre a definição dos desenhos regionais para incorporar a diversidade dos arranjos técnicos e políticos regionais da conformação do SUS nos estados. O Decreto 7.508 avançou em relação às regras do Pacto pela Saúde ao incorporar as redes de atenção à saúde e um rol mínimo de ações e serviços de saúde (com base na Renases e Rename) como elementos constitutivos das regiões de saúde.

Em relação aos objetivos da regionalização, o Pacto pela Saúde inovou ao focar as demandas de saúde da população, a integralidade, a diminuição das desigualdades socioespaciais em saúde e o fortalecimento do papel dos estados no planejamento e na coordenação e cooperação intergovernamental. Além de considerar os objetivos propostos pelo Pacto, o Decreto $\mathrm{n}^{\circ} 7.508$ ampliou-os significativamente, conferindo maior complexidade técnica, política e normativa ao processo de regionalização. Focou: a compatibilização e integração do processo de planejamento em saúde, considerando as diretrizes da política nacional, estadual e municipal; a segurança jurídica na relação intergovernamental regional (Coap); a integração das ações e serviços em redes de atenção à saúde e o fortalecimento da coordenação das redes; a associação entre planejamento e orçamento, tendo a região 
de saúde como referência para a transferência de recursos; e a condução da política regional baseada em resultados e metas. O Decreto $\mathrm{n}^{\circ} 7.508$ destacou o papel das redes de atenção no planejamento regional do SUS, que devem ser estruturadas e pactuadas regionalmente, ainda que seus componentes e fluxos assistenciais extrapolem esse limite. O sistema logístico das redes (transporte sanitário e regulação) e a perspectiva de garantia do acesso integral às ações e serviços conforme as necessidades da população devem ordenar os fluxos assistenciais regionais e entre as regiões de saúde.

Em relação aos critérios de regionalização, o Pacto pela Saúde inovou ao considerar as identidades (e não apenas as características) culturais, sociais e econômicas regionais, as redes de comunicação, infraestrutura e transporte, as demandas da população (e não apenas a oferta de serviços de saúde) e, finalmente, a necessidade de cooperação intergovernamental. Além desses, o Decreto $\mathrm{n}^{\mathrm{o}} 7.508$ considera critérios de acessibilidade, economia de escala e um rol mínimo de ações e serviços, que inclui atenção primária, urgência e emergência, atenção psicossocial, ambulatorial especializada e hospitalar, e vigilância em saúde (definidos com base na Renases e Rename). A existência de redes de atenção à saúde não é um critério de regionalização, mas, sim, um de seus objetivos, dado que as diretrizes e as políticas para a estruturação das mesmas (redes temáticas) são muito recentes.

Em relação aos desenhos regionais, o Pacto pela Saúde tornou livre a divisão regional, incluindo a possibilidade de conformação de regiões interestaduais de saúde. O Decreto relativizou a liberdade do desenho regional ao condicionar a existência de regiões de saúde ao cumprimento dos critérios mínimos de oferta de ações e serviços assistenciais, restringindo coexistência de diferentes escalas (macro e micro) de regionalização nos estados.

Em relação ao conjunto de instrumentos de planejamento, gestão e financiamento regional, o Decreto $\mathrm{n}^{\mathrm{o}} 7.508$ modificou-o radicalmente visando compatibilizar e coordenar as políticas dos entes federados nas regiões e vincular as metas e os investimentos às necessidades de saúde da população. Manteve apenas os indicadores de monitoramento e os grandes blocos de financiamento, agregando o orçamento às prioridades políticas definidas. 
Considera-se um grande avanço a proposta de construção do Mapa da Saúde, pois este se constitui instrumento imprescindível para o planejamento regional, integrando espacialmente um conjunto de informações estratégicas sobre a conformação do sistema de saúde e outras necessárias à compreensão das realidades locais. O Mapa deverá facilitar a sistematização, a consulta e a análise integrada dos dados mapeados por município, região de saúde, estados e macrorregiões brasileiras. Destaca-se que o mapeamento dos recursos financeiros por região de saúde, agregando informações dos três níveis de governo, será uma contribuição fundamental ao planejamento. Possivelmente, por razões diversas, serão os dados mais difíceis de serem obtidos e mapeados. Destaca-se ainda que, apesar do discurso ministerial marcar a necessidade de garantir o atendimento em tempo hábil, o mapeamento dos fluxos assistenciais abrange apenas "caminho e distância percorridos pelos usuários, mediante a apuração de residência e ocorrência de eventos" $"$, mas, não o tempo de espera para a realização do atendimento e para a resolução do problema de saúde. A demora no acesso e na resolução das demandas é uma das questões mais críticas do atendimento do SUS à população, tratando-se, portanto, de uma informação estratégica para a identificação de intervenções necessárias no combate às desigualdades em saúde.

Chama a atenção o fato de que o mapa de saúde só começou a ser elaborado no âmbito da política nacional a partir da segunda década dos anos 2000, um atraso inexplicável considerando-se a importância estratégica de tal instrumento para o planejamento da universalização da saúde, as possibilidades tecnológicas de mapeamento (geoprocessamento) já disponíveis no mundo e no Brasil na década de 1990, e a produção de mapeamentos pelas esferas municipais e estaduais para o planejamento do sistema e de sua organização regional, nos anos 2000. Esse fato corrobora com a constatação de que o território não foi objeto principal da política nacional para a implantação do SUS (VIANA et. al., 2007, 2011).

A maior inovação introduzida pelo Decreto 7.508 foi o Contrato Organizativo da Ação Pública de Saúde (Coap) que, diferentemente do termo de compromisso de gestão, trata-se de um instrumento multilateral de gestão e que tem um valor jurídico reconhecido (Ipea, 2012). Parte-se do pressuposto de que o alcance da integralidade

\footnotetext{
${ }^{98}$ Diretrizes do Planejamento Integrado. Comissão Intergestores Tripartite, Brasília: janeiro de 2012.
} 
no acesso e da integração dos serviços e ações em redes de atenção à saúde depende, dentre outras coisas, do estabelecimento de regras claras e de acordos jurídicos entre os entes federados (BRASIL, 2012). O Coap deverá "concretizar" os acordos intergovernamentais regionais, estabelecendo responsabilidades sanitárias e financeiras de cada ente federado para o cumprimento das metas estabelecidas para a região de saúde.

O financiamento permaneceu organizado por blocos, como definido previamente pelo Pacto pela Saúde, mas foi regulamentado pela Lei n ${ }^{\circ}$ 141/2012, que definiu recursos mínimos destinados às ações e serviços públicos de saúde, as responsabilidades de cada esfera de governo e o que é considerado gasto em saúde. A Parte III do Coap, que dispõe sobre as responsabilidades orçamentárias e financeiras, configura o financiamento regional a partir da definição: das responsabilidades dos entes federativos, do custeio, dos investimentos, das formas de incentivo, do cronograma de desembolso e das regras nacionais e estaduais sobre financiamento (Resolução no 3, Art.09, BRASIL, 2012). Contudo, observa-se que os recursos não aparecem vinculados diretamente às metas estabelecidas por indicador e objetivo da política de saúde.

A região e as redes de atenção à saúde tornaram-se as principais referências para as transferências de recursos e os investimentos estaduais e federais no SUS. No caso das redes, os recursos federais são transferidos aos estados e municípios conforme definido nas portarias específicas das redes temáticas e seus planos de ação nos estados. Está em processo de elaboração uma portaria que altera os blocos de financiamento, incluindo um específico de Investimentos na Rede de Serviços de Saúde (reunião da CIT $^{99}$, dezembro de 2012). Com o fim dos termos de compromisso de gestão (Pacto pela Saúde), o financiamento federal dos componentes das redes de atenção à saúde representa um recurso novo e, por enquanto, o principal poder de indução do Ministério da Saúde sobre as políticas regionais.

Outra importante inovação foi criação da Relação Nacional de Ações e Serviços de Saúde (Renases) que, juntamente com a Relação Nacional de

${ }^{99}$ Disponível em: http://portal.saude.gov.br/portal/arquivos/pdf/3a_121212.pdf. 
Medicamentos Essenciais (Rename), existente desde $1998^{100}$, definem o que está coberto pelo SUS e em que condições, isto é, criam parâmetros para os conceitos de integralidade da atenção e de acesso universal e igualitário aos serviços. A delimitação das ações, serviços e medicamentos oferecidos pelo SUS a toda população é importante por dois motivos. Primeiro, porque se define detalhadamente o que está garantido como direito universal à saúde, o que é essencial e o que é prioritário. Segundo, porque qualifica os instrumentos de gestão de tecnologias em saúde, dado que a atualização do rol de serviços, ações e medicamentos deverá ser realizada com base em estudos de custo-efetividade, criando uma barreira para a incorporação desenfreada e aleatória de tecnologias em saúde; processo que vem encarecendo sobremaneira os sistemas de saúde no mundo. Terceiro, porque favorece a incorporação de uma diversidade de tecnologias assistenciais utilizadas nos lugares e regiões do país, pois possibilita a adoção de relações específicas e complementares de ações, serviços e medicamentos pelos estados e municípios, em consonância com a Renases e a Rename. Essas relações complementares devem ser pactuadas nas respectivas Comissões Intergestores, respeitadas as responsabilidades dos entes pelo seu financiamento (Art.23, 24 e 27 do Decreto $n^{\circ}$ 7.508/11).

Finalmente, a política focada nas metas, nos resultados e na satisfação das necessidades de saúde dos usuários tem como um dos instrumentos de avaliação do sistema o Índice de Desempenho do SUS (IDSUS). Criado em 2011, o IDSUS é um indicador síntese que avalia o acesso (potencial e obtido) e a efetividade das ações e serviços conforme o nível de atenção (básica, ambulatorial, hospitalar, urgências e emergências). O IDSUS cruza uma série de indicadores simples e compostos para avaliar o acesso e a efetividade, organizando os municípios, regiões de saúde e estados por grupos homogêneos ${ }^{101}$, evitando distorções comparativas entre realidades brasileiras muito diversas quanto às condições sociais, econômicas, culturais, setoriais e territoriais. Os resultados da avaliação podem ser mapeados, agregando

\footnotetext{
${ }^{100}$ De acordo com o Ministério da Saúde, o Brasil elabora listas de medicamentos essenciais desde 1964. Mas, foi a partir da publicação da Portaria n ${ }^{\circ}$ 3.916/GM, de 30 de outubro de 1998, que aprovou a Política Nacional de Medicamentos, é que a atualização constante dessa lista, denominada Relação Nacional de Medicamentos Essenciais (Rename), se tornou prioritária.

${ }^{101} \mathrm{~A}$ formação dos Grupos Homogêneos, segundo as suas semelhanças, ocorreu por meio da utilização de três índices: o Índice de Desenvolvimento Socioeconômico (IDSE); o Índice de Condições de Saúde (ICS); e o Índice de Estrutura do Sistema de Saúde do Município (IESSM) (Fonte: Ministério da Saúde).
} 
mais informações à análise espacial sobre o funcionamento do SUS e sobre a evolução das condições de saúde da população, essencial para o planejamento regional.

Por fim, em relação aos responsáveis pela regionalização, a principal inovação foi introduzida pelo Pacto pela Saúde, que responsabilizou o estado e todos os municípios que compõem a região de saúde pelo planejamento e criou um espaço específico para a negociação intergovernamental regional (CGR). O Decreto $\mathrm{n}^{\circ} 7.508$ manteve esse espaço, mudando a nomenclatura para Comissão Intergestores Regional (CIR), adequando à forma e função das comissões intergestoras do SUS (Lei 12.466, de 2011). Destaca-se que a Comissão Intergestora Tripartite (CIT) ganhou maior importância na regionalização após o Pacto e, sobretudo, o Decreto $\mathrm{n}^{\circ}$ 7.508, porque além de ser um espaço de negociação do planejamento regional no caso das regiões instituídas na zona de fronteira internacional, a CIT também foi o espaço privilegiado para a negociação das novas diretrizes de regionalização do SUS, durante o processo de formulação do Decreto n 7.508 , em 2011. 
Quadro 3 - Diretrizes nacionais de regionalização do Sistema Único de Saúde: definições, critérios, objetivos, responsáveis, divisões e instrumentos (Brasil, 2001-2011)

\begin{tabular}{|c|c|c|c|}
\hline & $\begin{array}{c}1^{\text {a }} \text { fase } \\
\text { NOAS }(2001 / 02) \\
\text { "REGIÃO NORMATIVA" }\end{array}$ & $\begin{array}{c}2^{\mathrm{a}} \text { fase } \\
\text { PACTO PELA SAÚde (2006) } \\
\text { "REGIÃo VIVA” }\end{array}$ & $\begin{array}{c}3^{\text {a }} \text { fase } \\
\text { DECRETO 7508 (2011) } \\
\text { “REGIÃO CONTRATUALIZADA" }\end{array}$ \\
\hline $\begin{array}{l}\text { Definição de } \\
\text { região }\end{array}$ & $\begin{array}{l}\text { Base territorial de planejamento da atenção à } \\
\text { saúde, não necessariamente coincidente com a } \\
\text { divisão administrativa do estado. } \\
\text { Elementos: limite geográfico dos territórios } \\
\text { municipais envolvidos, população usuária, } \\
\text { fluxos assistenciais, ações e serviços de média } \\
\text { complexidade (MC) e responsabilidades } \\
\text { (habilitação da gestão) dos entes federativos. }\end{array}$ & $\begin{array}{l}\text { Recortes territoriais inseridos em espaços } \\
\text { geográficos contínuos, não necessariamente } \\
\text { coincidentes com a divisão administrativa do } \\
\text { estado. } \\
\text { Elementos: limite geográfico dos territórios } \\
\text { municipais envolvidos, população usuária, fluxos } \\
\text { assistenciais, ações e serviços de Atenção Básica } \\
\text { (AB), Média e Alta Complexidade e Vigilância } \\
\text { Sanitária (VS), Colegiados de Gestão Regional. }\end{array}$ & $\begin{array}{l}\text { Espaço geográfico contínuo constituído por } \\
\text { agrupamentos de Municípios limítrofes. } \\
\text { Elementos: limite geográfico dos territórios } \\
\text { municipais envolvidos, população usuária, fluxos } \\
\text { assistenciais, redes de atenção à saúde com rol } \\
\text { mínimo de ações e serviços (Atenção Primária em } \\
\text { Saúde - APS, Urgência e Emergência - UE, atenção } \\
\text { psicossocial; ambulatorial especializada e hospitalar } \\
\text { e Vigilância Sanitária), Comissão Intergestores } \\
\text { Regional (CIR). }\end{array}$ \\
\hline $\begin{array}{l}\text { Objetivo da } \\
\text { regionalização }\end{array}$ & $\begin{array}{l}\text { Ampliar o acesso às ações e serviços de saúde } \\
\text { em todos os níveis de atenção, por meio da } \\
\text { conformação de sistemas funcionais de saúde } \\
\text { e definindo-se um conjunto mínimo de } \\
\text { procedimentos de média complexidade (MC) } \\
\text { como primeiro nível de referência } \\
\text { intermunicipal a toda a população no âmbito } \\
\text { microrregional, ofertados em um ou mais } \\
\text { módulos assistenciais. Descentralizar as ações } \\
\text { e serviços em saúde. Fortalecer o papel dos } \\
\text { estados no planejamento. Equidade. }\end{array}$ & $\begin{array}{l}\text { Atender às demandas das populações dos } \\
\text { municípios a elas vinculados, garantindo o acesso, } \\
\text { a equidade e a integralidade do cuidado com a } \\
\text { saúde local. Diminuir as desigualdades } \\
\text { socioespaciais de universalização da saúde, } \\
\text { superar os limites do modelo de descentralização } \\
\text { municipalista da saúde e fortalecer o papel dos } \\
\text { estados no planejamento e na coordenação / } \\
\text { cooperação intergovernamental. }\end{array}$ & $\begin{array}{l}\text { Compatibilizar e integrar o processo de } \\
\text { planejamento dos entes federativos. Garantir } \\
\text { segurança jurídica para as relações intergovernamentai } \\
\text { na região de saúde (Contrato organizativo - Coap). } \\
\text { Integrar a organização, o planejamento e a execução } \\
\text { de ações e serviços de saúde, por meio da conformação } \\
\text { das Redes de Atenção à Saúde. Associar } \\
\text { planejamento e orçamento: região como referência } \\
\text { para transferência de recursos entre os entes } \\
\text { federados. Diminuir as desigualdades socioespaciais } \\
\text { de universalização da saúde, superar os limites do } \\
\text { modelo de descentralização municipalista da saúde e } \\
\text { fortalecer o papel dos estados no planejamento e na } \\
\text { coordenação / cooperação intergovernamental. } \\
\text { Governança das redes. Metas e resultados. }\end{array}$ \\
\hline
\end{tabular}




\begin{tabular}{|c|c|c|c|}
\hline $\begin{array}{l}\text { Critérios para } \\
\text { regionalização }\end{array}$ & $\begin{array}{l}\text { Características demográficas, } \\
\text { socioeconômicas, geográficas, sanitárias, } \\
\text { epidemiológicas, oferta de serviços, relações } \\
\text { entre municípios, entre outras. O conjunto } \\
\text { mínimo de serviços de média complexidade } \\
\text { compreende as atividades ambulatoriais de } \\
\text { apoio diagnóstico e terapêutico e de } \\
\text { internação hospitalar. }\end{array}$ & $\begin{array}{l}\text { Identidades culturais, econômicas e sociais, } \\
\text { características epidemiológicas, existência de } \\
\text { redes nas áreas de comunicação, infraestrutura, } \\
\text { transportes e saúde. Deve estar garantido o } \\
\text { desenvolvimento da atenção básica (AB) da } \\
\text { assistência e parte da média complexidade (MC), } \\
\text { assim como as ações básicas de vigilância em } \\
\text { saúde (VS). Considera as demandas da } \\
\text { população. Cooperação intergovernamental. }\end{array}$ & $\begin{array}{l}\text { Identidades culturais, econômicas e sociais, } \\
\text { características epidemiológicas, e redes de } \\
\text { comunicação e transportes compartilhadas. Deve } \\
\text { conter, no mínimo, ações e serviços de: atenção } \\
\text { primária (APS); urgência e emergência } \\
\text { (UE); atenção psicossocial; atenção ambulatorial } \\
\text { especializada e hospitalar; e vigilância em saúde } \\
\text { (VS). Critérios de acessibilidade e escala. }\end{array}$ \\
\hline $\begin{array}{l}\text { Desenhos } \\
\text { regionais }\end{array}$ & $\begin{array}{l}\text { Macrorregiões; regiões e/ou microrregiões de } \\
\text { saúde; módulos assistenciais. }\end{array}$ & $\begin{array}{l}\text { As Regiões de Saúde podem assumir diferentes } \\
\text { desenhos, intraestaduais e interestaduais. } \\
\text { "Regionalização viva" }\end{array}$ & $\begin{array}{l}\text { As Regiões de Saúde podem assumir diferentes } \\
\text { desenhos, intraestaduais e interestaduais, desde que } \\
\text { garantam a oferta do rol mínimo de ações e serviços de } \\
\text { saúde (critérios de regionalização; referência: Renases } \\
\text { e Rename). Não mais existindo diferentes escalas } \\
\text { (macro e micro) de regionalização. }\end{array}$ \\
\hline $\begin{array}{l}\text { Instrumentos de } \\
\text { planejamento } \\
\text { regional }\end{array}$ & $\begin{array}{l}\text { Habilitações } \\
\text { Programação Pactuada e Integrada (PPI) } \\
\text { Plano Diretor de regionalização (PDR) } \\
\text { Plano Diretor de Investimentos (PDI) } \\
\text { Centrais de regulação } \\
\text { Financiamento por elenco de procedimentos } \\
\text { (níveis de atenção, tipo de serviços, programas } \\
\text { e funções) e transferências per capita. }\end{array}$ & $\begin{array}{l}\text { Termos de compromisso de gestão } \\
\text { PPI, PDR, PDI } \\
\text { Indicadores de monitoramento } \\
\text { Complexos reguladores } \\
\text { Financiamento por blocos (Atenção básica, } \\
\text { Atenção de média e alta complexidade, Vigilância } \\
\text { em Saúde, Assistência Farmacêutica e Gestão do } \\
\text { SUS) } \\
\text { Normas internacionais (regiões de fronteira) }\end{array}$ & $\begin{array}{l}\text { Contrato Organizativo da Ação Pública de Saúde } \\
\text { (Coap) } \\
\text { Planos de saúde contendo metas de saúde } \\
\text { (planejamento integrado dos entes) } \\
\text { Mapa de Saúde (federal, estadual e regional) } \\
\text { Renases } \\
\text { Rename } \\
\text { Redes de atenção à saúde } \\
\text { Índice de desempenho do SUS (IDSUS) } \\
\text { Sistema logístico das redes (transporte sanitário e } \\
\text { regulação) } \\
\text { Financiamento por blocos e por componentes das } \\
\text { redes de atenção à saúde } \\
\text { Normas internacionais (regiões de fronteira) }\end{array}$ \\
\hline $\begin{array}{l}\text { Responsáveis pela } \\
\text { regionalização }\end{array}$ & $\begin{array}{l}\text { Secretarias Estaduais de Saúde } \\
\text { Comissão Intergestores Bipartite (CIB) }\end{array}$ & $\begin{array}{l}\text { Secretarias Estaduais de Saúde } \\
\text { Secretarias Municipais de Saúde } \\
\text { Colegiados de Gestão Regional } \\
\text { CIB } \\
\text { Comissão Intergestores Tripartite (CIT) (no } \\
\text { caso de regiões nas áreas de fronteira } \\
\text { internacional) }\end{array}$ & $\begin{array}{l}\text { Secretarias Estaduais de Saúde } \\
\text { Secretarias Municipais de Saúde } \\
\text { Comissão Intergestores Tripartite (CIT) (no caso de } \\
\text { regiões nas áreas de fronteira internacional; na } \\
\text { discussão das diretrizes de regionalização) } \\
\text { Comissão Intergestores Bipartite (CIB) } \\
\text { Comissão Intergestores Regional (CIR) }\end{array}$ \\
\hline
\end{tabular}

Elaboração própria, adaptado de Ibañez \& Albuquerque (2012, p.123-125), com base nas diretrizes nacionais de regionalização do SUS. 
O Decreto $\mathrm{n}^{\mathrm{o}} 7.508$ inaugurou a fase da "regionalização contratualizada", cuja institucionalização depende do acordo jurídico entre as três esferas de governo em torno da construção e efetivação de um plano regional de universalização da saúde.

Por conta das inovações introduzidas, esta terceira fase se caracteriza pela maior densidade e complexidade normativa, técnica, científica, informacional e política dos instrumentos de planejamento, financiamento e gestão regional do SUS.

O nível federal tenta aumentar seu poder de indução sobre os processos de regionalização nos estados, sem ferir autonomias e diversidades locais de conformação do SUS, mas incentivando agrupamentos municipais que apresentem uma maior capacidade técnica, política e financeira para ampliação dos investimentos públicos e da oferta assistencial, buscando responder às necessidades de saúde da população. Procura-se, assim, amenizar o quadro das desigualdades territoriais da universalização da saúde através das solidariedades organizacionais entre os entes federados, formalizadas por meio dos contratos organizativos da ação pública em saúde.

Esse tipo de regionalização procura estabelecer as regras da descentralização (autonomia federativa) e, sobretudo, os instrumentos de gestão compartilhada (de interdependência organizativa do SUS) reforçando o caráter cooperativo e solidário entre os entes federados e oferecendo uma estrutura jurídico-administrativa ao sistema, necessários à integração e à integralidade das ações e serviços de saúde (SANTOS, 2012). O Coap estabelece "os elos necessários entre os entes federativos na fixação de suas responsabilidades sanitárias" (SANTOS, 2012, p.89).

A região de saúde existe em função do compartilhamento de questões comuns e de processos e políticas assistenciais integrados. Mas a região não existe por ela mesma, mas, sim, em relação às outras regiões de saúde.

O rol mínimo e máximo de ações e serviços de saúde garantidos na região (especialidades produtivas) e a forma de solidariedade ou cooperação com outras regiões para cumprir a integralidade na assistência à saúde (redes e fluxos assistenciais) estruturam o processo produtivo no SUS e definem as funções de cada lugar e região na divisão territorial do trabalho em saúde. 
Os COAP deverão expressar o papel de cada uma das regiões de saúde na divisão territorial do trabalho em saúde e a universalização e a integralidade dependerão da solidariedade organizacional intra e inter-regiões de saúde.

Conforme apontou Lenir Santos (2012, p.88-89):

Até o presente momento, são poucas as reais redes de atenção à saúde, uma vez que não há sistema informatizado que interligue seus serviços no âmbito da rede regional ou inter-regional, dando-lhe o substrato necessário para atuar como uma real rede integrada de ações e serviços de saúde. [...] Por fim, a rede ainda não se construiu (impedimentos políticos; resistências dos hospitais em se integrar pelo medo de aumentar o controle sobre seu funcionamento; dificuldade dos estados em compor regiões etc.). [...] Por isso é importante que a instituição da região de saúde seja ato obrigatório do estado, com a finalidade de garantir institucionalidade a essa forma organizativa, com o contrato estabelecendo os elos necessários entre os entes federativos na fixação de suas responsabilidades sanitárias.

Os novos instrumentos de planejamento e gestão compartilhada revelam maior complexidade e institucionalidade da regionalização do SUS na política nacional de saúde.

Entretanto, a região contratualizada não se concretiza apenas por meio dos contratos organizativos $^{102}$, mas, sobretudo, pelas relações intergovernamentais estabelecidas e pelas conexões geográficas entre lugares contíguos que compartilham fixos e fluxos assistenciais diversos e questões comuns a serem resolvidas pelas políticas públicas. A regionalização do SUS é condicionada por fatores históricoestruturais, territoriais, políticos-institucionais e conjunturais (VIANA \& LIMA, 2011), que resultam em diferentes capacidades técnicas, políticas, financeiras e informacionais dos estados e municípios para a conformação de regiões contratualizadas e suas redes de atenção à saúde.

Em tese, a "região de saúde contratualizada" se estrutura a partir da conjugação de esforços técnicos, políticos e financeiros dos três entes federados em torno de um projeto regional de saúde comum. O contrato organizativo deve expressar o interesse e o projeto que gerou determinado agrupamento de municípios. Contudo, a regionalização do SUS envolve diferentes projetos e interesses, sendo

102 A região de saúde contratualizada deverá ter a mesma duração da vigência do Contrato Organizativo (Coap), que vai variar conforme cada contrato, ainda que o tempo sugerido pelas normas seja de quatro anos. 
fortemente influenciada pela diversidade de atores e instituições envolvidos na conformação do sistema e das políticas de saúde nos estados (FLEURY E OUVERNEY, 2007; VIANA \& LIMA, 2011).

As regiões de saúde possuem distintas densidades tecnológicas e capacidades de oferta de ações e serviços de saúde. A própria noção de rede regionalizada de atenção à saúde pressupõe a região como atributo fundamental para sua organização e funcionamento. Esta depende da existência de um conjunto de unidades (ou pontos de atenção), com diferentes funções, complexidades e perfis de atendimento, e de sistemas de informação e regulação para que as unidades operem de forma ordenada e articulada no território, de modo a atender as necessidades de saúde da população.

Muitas regiões de saúde existentes desde a Noas e o Pacto poderão ser reformuladas seguindo as mudanças introduzidas pelo Decreto 7.508. Entretanto, as dinâmicas territoriais e as regionalizações pretéritas criam estruturas espaciais produtivas, fluxos e identidades que não se desfazem prontamente em resposta às mudanças políticas e normativas (SILVA NETO, 2003), constrangendo as intenções e as ações de planejamento regional do Estado.

O Mapa da Saúde, o IDSUS e o Coap têm grande potencial para criar uma nova e importante base regionalizada de dados e informações sobre o sistema de saúde e as situações sanitárias. Mas é cedo para avaliar se essa base informacional regional servirá como subsídio para a caracterização e avaliação dos condicionantes citados, assim como, para a elaboração de uma visão mais ampla e estratégica sobre o papel dos usos do território na determinação das desigualdades e dos desafios de organização, integração, contratualização, gestão, acesso, financiamento e planejamento do sistema de saúde; sobretudo, por parte do governo federal.

O planejamento regional do SUS requer a incorporação de elementos de diferenciação e diversidade socioespacial na formulação e implementação de políticas de saúde (VIANA et al., 2007 e 2008), a integração de diversos campos da atenção à saúde e a articulação de políticas econômicas e sociais voltadas para a redução das desigualdades regionais (GADELHA ET AL., 2009).

Em síntese, a descentralização, na década de 1990, não favoreceu processos de coordenação intergovernamentais para gerar uma racionalidade sistêmica e cooperativa da divisão territorial do trabalho em saúde. Pelo contrário, ajudou a 
aprofundar as desigualdades territoriais concentrando recursos, equipamentos e fluxos assistenciais nos municípios e estados já concentradores de outras variáveis do desenvolvimento econômico. A descentralização acabou incentivando a competitividade entre os entes federados pela atratividade de recursos públicos e privados no sistema de saúde, prejudicando o estabelecimento de relações intergovernamentais mais cooperativas e coordenadas no âmbito da assistência à saúde.

A descentralização num contexto de crise fiscal e de grande desigualdade quanto às condições sociais e econômicas entre os municípios brasileiros, desfavoreceu não apenas a adoção de estratégias de regionalização, mas, também, a estruturação de redes assistenciais regionalizadas.

O atraso para a elaboração de uma definição de redes de saúde e seus instrumentos de planejamento e gestão também prejudicou a materialização da lógica sistêmica, coordenada, cooperativa e regional de funcionamento do SUS. A região de saúde depende das redes, pois este é o grande instrumento para integrar serviços e ações assistenciais e criar uma solidariedade organizacional entre lugares (fluxos, especializações e responsabilidades), concretizando a divisão territorial e regional do trabalho na saúde.

A regionalização surgiu como uma diretriz que busca reverter a lógica fragmentada, competitiva, desigual e desordenada de conformação do SUS, procurando construir uma racionalidade sistêmica e cooperativa para a divisão territorial do trabalho na saúde pública. A complexidade dessa estratégia exigiu a definição de novos instrumentos e conceitos de planejamento e gestão, que aumentaram a densidade normativa, informacional, técnica e política do processo de regionalização do SUS.

Em dez anos, as diretrizes nacionais progrediram no sentido de tornar a região de saúde o lócus privilegiado para induzir mudanças técnicas e políticas no sistema, visando construir uma racionalidade sistêmica e cooperativa na divisão territorial do trabalho e garantir uma ação mais eficaz do Estado na universalização da saúde, em todo o território. 
De uma "regionalização normativa" passou-se para a "regionalização viva" e, em seguida, para a fase da "regionalização contratualizada", quando o enfoque das redes de atenção à saúde ganhou centralidade.

A capacidade do Estado de induzir e regular a divisão territorial do trabalho na saúde tende a ser reforçada pelas normas e instrumentos de planejamento, financiamento e gestão do SUS. Contudo, nos estados, a complexa dinâmica socioespacial, econômica e política impõem limitações e adaptações às lógicas regionais idealizadas pelas diretrizes nacionais. 


\section{Capítulo 3. Redes de atenção à saúde e redes interfederativas como bases técnicas e políticas da regionalização do Sistema Único de Saúde}

As redes são elementos estruturadores das regiões de saúde. Diferentes noções de rede assistencial influenciaram mudanças nas diretrizes de regionalização do SUS. Na fase atual da regionalização contratualizada, destacam-se os conceitos de redes de atenção à saúde e de redes interfederativas de saúde; e o vínculo das regiões de saúde com a conformação das redes aumenta ainda mais a complexidade do planejamento regional da saúde.

\subsection{As diferentes noções de rede de saúde que influenciaram a política nacional}

Duas correntes internacionais tiveram maior influência sobre as noções de rede de saúde incorporadas no planejamento regional do Sistema Único de Saúde. A primeira de origem inglesa, vinculada ao sistema universal de saúde, com a proposta da organização das redes assistenciais regionalizadas e hierarquizadas (Informe Dawson, 1920). A segunda de origem norte-americana, vinculada ao setor privado, com a proposta de sistemas integrados de saúde, adaptada para o Brasil a partir do conceito de redes de atenção à saúde (OPAS, 2010; MENDES, 2010; KUSCHINIR \& CHORNY, 2010).

Antes da criação do SUS, a constituição e organização de redes assistenciais sofreu grande influência do modelo norte-americano de Centros de Saúde (CS), difundido pela Fundação Rockfeller no início do século XX, deixando marcas na organização do SUS até recentemente, através da ideia de integração das ações assistenciais, sendo contraposto atualmente pelos novos componentes gerenciais das redes integradas de atenção à saúde (MELLO et al., 2011; MELLO \& VIANA, 2012).

O Informe Dawson, produzido na Inglaterra em 1920, continha uma proposta de reorganização dos serviços médicos em redes com centros de saúde primários, 
secundários e hospitais de ensino e a abrangência regional de acesso aos mesmos, é uma importante referência para o debate sobre redes assistenciais e regionalização do SUS.

Este documento inspirou, no contexto dos sistemas universais de saúde, a ideia de rede regionalizada como forma de organização da provisão de serviços de saúde para uma população, numa dada região, com o objetivo de articular a medicina preventiva e curativa e garantir a atenção integral à saúde de forma equitativa para toda população (KUSCHINIR \& CHORNY, 2010). Alguns dos conceitos que embasaram esta proposta tornaram-se referências importantes e ainda atuais para a organização dos serviços de saúde em rede e para a definição de regiões de saúde: critérios de delimitação; a ideia de comunidade; a eficiência/escala e qualidade; e a criação da autoridade de saúde única no território, responsável pela coordenação das referências entre os níveis e/ou regiões.

O Informe Dawson apontava a necessidade de expansão dos serviços de saúde com o objetivo de garantir a melhoria das condições de saúde da população, a partir da organização do sistema de serviços em uma dada "região" (não chegou a definir região ou regionalização). O Informe também indicava a revisão da administração dos serviços mediante sua expansão e organização regional, conforme as necessidades da população de uma dada área - a comunidade ${ }^{103}$.

Tratava-se de uma divisão técnica, gerencial e territorial do trabalho no setor saúde. Dawson relacionou hierarquia dos serviços (especialidade do tratamento; variedade de equipamentos e profissionais) com a hierarquia urbana (porte populacional; equipamentos e serviços; função rural ou urbana) e a rede de transporte e comunicação, criando uma organização regional de um sistema de serviços de saúde, conforme a complexidade e a complementaridade entre eles (Informe 1964).

\footnotetext{
103 "La disponibilidad general de los servicios médicos sólo puede asegurarse mediante una organización nueva y ampliada, distribuída en función de las necesidades de la comunidad. Tal organización es indispensable por razones de eficiencia y costo, como asimismo en beneficio del público y de la profesión médica. Con la expansión del conocimiento, las medidas necesarias para resolver los problemas de la salud y las enfermedades se tornan más complejas, reduciéndose el ámbito de la acción individual y exigiendo, en cambio, esfuerzos combinados. Para que éstos puedan rendir los mejores resultados deben concentrarse en la misma institución.” (Informe, 1964, p.03).
} 
Além disso, introduziu a ideia de autoridade única de saúde local ${ }^{104}$, que inspiraria as regionalizações de cunho administrativo.

Para garantia de acesso ao cuidado integral, a regionalização deveria ser baseada em territórios de grande porte populacional, com autossuficiência em recursos de saúde em todos os níveis de atenção, subdivididos em distritos, subregiões ou microrregiões. O conjunto estaria sob um único comando e deveria operar de forma coordenada através de mecanismos de referência entre níveis (e/ou territórios), alimentados por sistemas de informação e de transportes. (KUSCHNIR \& CHORNY, 2010, p.2309)

O Relatório Dawson foi engavetado e posteriormente retomado pelo Relatório Beveridge, em 1942, como subsídio para a estruturação do National Health System (NHS) inglês.

A proposta de organização de redes assistenciais regionalizadas e hierarquizadas tornou-se um referencial fundamental do planejamento dos sistemas universais de saúde, inclusive no Brasil. A primeira diretriz de regionalização do SUS, a Noas, surgiu embasada por essa ideia. Já o Pacto pela Saúde representou uma transição entre essa ideia e o conceito de redes de atenção à saúde, que estava sendo difundido internacionalmente pela Organização Mundial da Saúde e pela Organização Pan-americana de Saúde. Mas foi somente em 2010, quando o Ministério da Saúde publicou a Portaria 4.279, que se institucionalizou o conceito e as diretrizes para a conformação das redes de atenção à saúde no SUS, influenciando, posteriormente, as diretrizes de regionalização apresentadas no Decreto 7.508 de 2011.

O conceito de redes de atenção à saúde utilizado atualmente no Brasil é inspirado na ideia de sistemas integrados de saúde ${ }^{105}$ (SHORTELL et al., 1994),

\footnotetext{
104 "La práctica vigente en materia de administración de salud, que entraña una gran diversidad de responsabilidades, no permitirá lograr esta condición esencial, por lo que se necesitará un nuevo tipo de autoridad de salud que unifique el control local de todos los servicios de salud, tanto curativos como preventivos." (Informe, 1964,p.23)

$105 \mathrm{O}$ conceito de sistema integrado de saúde (integrated delivery systems-IDS) foi definido no trabalho de Shortell et al. The new world of managed care: creating organized delivery systems. Health Affairs, 1994. Conforme definido por Shortell et al (apud Mendes, 2007), a rede implica integração funcional para agregar valor ao sistema (gestão financeira, gerência de recursos humanos, planejamento estratégico, marketing, melhoria da qualidade), em integração profissional (grau de integração econômica dos médicos ao sistema, utilização dos serviços e participação no planejamento e gestão), e em integração clínica (continuidade do cuidado, coordenação, gestão de patologia,
} 
desenvolvido para o mercado privado americano e adaptado para sistemas públicos de saúde (MENDES, 2007, 2010; KUSCHNIR \& CHORNY, 2010; LIMA et al., 2012).

As redes de atenção à saúde, ainda que tenham suas origens na década de 20, no Reino Unido, a partir da concepção dawsoniana de sistemas públicos de saúde, toma forma, contemporaneamente, com os sistemas integrados de saúde, uma proposta surgida no início dos anos 90, nos Estados Unidos. Isso significa que foi gestada modernamente no ambiente de um sistema segmentado, com hegemonia do setor privado. Dos Estados Unidos foi levada, com as adaptações necessárias, a sistemas de saúde públicos e privados de outros países (MENDES, 2007, p.04).

Nos anos 2000, a ideia de sistemas integrados de saúde voltada para as políticas públicas começou a ser difundida pela Organização Mundial da Saúde (OMS), com a proposição de critérios e desenhos para a integração dos sistemas em arranjos organizacionais e a definição de um "novo universalismo", baseado na atenção primária de saúde mais seletiva (pacote essencial de serviços), na performance e no custo-efetividade das ações e serviços ofertados (WHO, 2000a, 2000b, p.15).

Em 2001, a OMS ${ }^{106}$ publicou um artigo valorizando a experiências dos países europeus na elaboração de políticas para a conformação de sistemas integrados de saúde, a partir da adaptação dos termos e mecanismos do modelo americano, tomando como exemplo o sistema integrado de saúde da Catalunha (Espanha) (GRÖNE et al., 2001). Em 2003, a Organização propôs substituir a classificação das doenças em transmissíveis e não-transmissíveis, pela classificação de condições crônicas $^{107}$ e condições agudas das enfermidades (WHO/HEN, 2003), contribuindo para os fundamentos dos sistemas integrados e redes de atenção à saúde nas políticas

comunicação entre prestadores para evitar duplicação de procedimentos). As redes também implicam integração vertical e horizontal no contexto da cadeia de valor (TOOD, 1996 apud MENDES, 2007): a integração horizontal entre duas ou mais unidades que produzem serviços semelhantes visa ganho de escala e fatias de mercado; a integração vertical ocorre dentro de uma organização ou entre diferentes unidades que complementam os serviços oferecidos, visando redução de custos e aumento de produtividade através do compartilhamento de recursos. Os principais tipos de integração vertical seriam a fusão das unidades numa mesma organização ou contratos e franquias (integração virtual).

${ }^{106}$ WHO European Office for Integrated Health Care Services.

107 Abarca doenças transmissíveis (HIV/AIDS, tuberculose, hanseníase), doenças não transmissíveis (cardíacas, diabetes, câncer), os distúrbios mentais e as deficiências físicas. As condições crônicas são a principal causa de morbimortalidade no mundo. 
públicas, facilitando a identificação de estratégias de gerenciamentos similares e eficazes para as condições crônicas ${ }^{108}$ (MENDES, 2007).

Os modelos de gestão de sistemas integrados de saúde e de cuidado às condições crônicas foram introduzidos em países como Canadá, França, Espanha, Alemanha e Inglaterra, no contexto das reformas dos sistemas de proteção social de saúde ${ }^{109}$, nos anos 90. Na América Latina, esses modelos começaram a ser adaptados a partir da conformação das redes no Peru e no Chile, durante a década de 1990, e em países como Colômbia, Cuba, México, República Dominicana e Brasil, a partir dos anos 2000.

No Chile, utilizaram a denominação de redes territoriais, organizadas pela oferta de ações e serviços; na República Dominicana as redes conformaram os Serviços Regionais de Saúde; e na Colômbia foi definida uma regionalização para as redes de atenção à saúde, estruturadas por níveis de complexidade dos serviços e coordenadas pelas diretorias territoriais de saúde (MENDES, 2007).

No Brasil, a experiência pioneira de regionalização com base na concepção de sistemas integrados de saúde, através da microrregionalização cooperativa, aconteceu no estado do Ceará, em 1998, com o apoio do Reino Unido (KEINERT, 2001; MENDES, 2003; SILVA, 2004; LOPES, 2007). Curitiba foi o primeiro município a implantar a experiência de sistema integrado de saúde com redes de atenção à saúde, em 2001, e o Estado de Minas Gerais foi o primeiro a formular uma política de redes de atenção à saúde, em 2006, que resultou na revisão da regionalização da saúde, com a incorporação dos princípios de estruturação das redes: escala, escopo, qualidade e acesso (MENDES, 2007; PEREIRA, 2009).

\footnotetext{
${ }^{108}$ Dentre os enfoques dos cuidados inovadores para as condições crônicas, propostos pela OMS, que se relacionam com a proposta de redes de atenção e regionalização estão: "ii. Enfoque na população: as ações devem estar dirigidas a uma população adscrita ao sistema de saúde, mais que a indivíduos isolados. v. Integração: a integração é o cerne do modelo porque, em relação aos problemas crônicos, a atenção à saúde requer integração sob múltiplos aspectos. A integração deve dar-se nos níveis micro [indivíduos e famílias], meso [organização de saúde e comunidade] e macro [políticas de saúde] do sistema de saúde e a integração, coordenação e continuidade devem ocorrer ao longo do tempo e em todos os âmbitos da saúde, incluindo as atenções primária, especializada e hospitalar. vi. Flexibilidade e adaptabilidade: Os sistemas de saúde devem estar preparados para se adaptarem a situações instáveis, informações novas e eventos imprevisíveis." (MENDES, 2007, p.21).

109 "Ao colocar no centro do debate a discussão da integração/coordenação do cuidado, o processo de reforma dos sistemas nacionais, em sua fase mais recente, passou a utilizar mecanismos e instrumentos próximos aos desenvolvidos no mercado americano." (KUSCHNIR \& CHORNY, 2010, p.2314).
} 
Os debates em torno do conceito de sistemas integrados de saúde e redes de atenção à saúde no âmbito da política nacional ganharam força com os estudos elaborados por consultores e pesquisadores nacionais e internacionais.

Dentre os organismos internacionais que investiram na implantação de redes de atenção à saúde no Brasil, destaca-se o Banco Mundial e a Organização Panamericana de Saúde.

O Banco Mundial propôs implantação de redes integradas de saúde no país como uma das estratégias para aumentar a eficiência de escala e escopo para os hospitais públicos brasileiros, diminuir a fragmentação do sistema e melhorar as condições de coordenação da atenção e do financiamento (La Forgia \& Couttolenc, 2008). Em 2009, o Banco aprovou um empréstimo para o Governo Brasileiro, de US\$ 235 milhões, para investimentos nas redes de atenção à saúde em regiões metropolitanas e outras priorizadas pelo Ministério da Saúde, no âmbito do Projeto de Investimentos para a Qualificação do Sistema Único de Saúde - QualiSUS Rede (BRASIL SF, 2009).

Em 2010, com base na consulta aos países latino-americanos e no trabalho de Shortell et al. (1994) (OPAS, 2008; 2010a), a Organização Pan-Americana de Saúde definiu o conceito de Redes Integradas de Serviços de Saúde - RISS para servir como marco conceitual para as políticas públicas de saúde dos países da região (OPAS, 2010a).

No Brasil, a OPAS relacionou o conceito de RISS com o processo de regionalização proposto no Pacto pela Saúde, utilizando o termo Redes de Atenção à Saúde (RAS) como sinônimo de RISS:

\footnotetext{
...uma rede de organizações que presta, ou faz arranjos para prestar, serviços de saúde equitativos e integrais a uma população definida e que está disposta a prestar contas por seus resultados clínicos e econômicos e pelo estado de saúde da população a que serve (OPAS, 2010b, p.17).
}

Sendo os elementos básicos das RAS: a população (sob a responsabilidade sanitária da rede, cadastrada na atenção primária à saúde); a estrutura operacional (nós das redes e as ligações materiais e imateriais que comunicam os diferentes nós); e o modelo de atenção à saúde (sistema lógico que estratifica a população por riscos 
e define os focos e os diferentes tipos das intervenções sanitárias do sistema de saúde, as linhas de cuidado).

O objetivo principal da implantação das redes de atenção à saúde no Brasil era aumentar o financiamento público de saúde e alinhar os recursos com os objetivos das RAS. Foi proposto um movimento de mudança que articulasse um incremento dos recursos financeiros para o SUS com a implantação concomitante das redes de atenção à saúde.

Só essa ação conjugada fará com que os recursos adicionais colocados no SUS gerem valor para a população brasileira. (...) Além disso, é necessário que o aporte de mais recursos seja acompanhado pela implantação de novo modelo de atenção à saúde, orientado pelas linhas de cuidado e de base territorial. Isso demandará incremento dos repasses financeiros per capita ("recursos seguindo usuários"), na redução radical da forma de repasse por produção e na efetivação de um modelo de gestão pautado no monitoramento e acompanhamento de indicadores de saúde. O maior aporte de recursos deverá tornar suficiente o financiamento da atenção primária e da média complexidade, além da alta complexidade. (OPAS, 2010b, p.63-67).

Segundo Kuschnir \& Chorny (2010, p.2314), ao citar os serviços de saúde equitativos e integrais o conceito de RAS "alinha-se no campo das redes regionalizadas dos sistemas públicos e fornece um marco conceitual para a organização de redes no caso brasileiro". Além disso, a proposta considera o contexto institucional do federalismo brasileiro e a necessidade de cooperação intergovernamental para a conformação das RAS.

Entretanto, além da tendência ao "novo universalismo", a proposta das RAS cria uma confusão entre as noções de rede, região e território, ao definir o território sanitário ou região de saúde como recortes espaciais de organização das redes, tendo como critério a população-alvo das redes. A regionalização aparece como sinônimo de territorialização das redes: cadastramento das famílias em um território sanitário singular (OPAS, 2010, p.19). Ao mesmo tempo, denomina diferentes "tipos" de território, conforme a escala de ação das redes e dos serviços de saúde: territórios de responsabilização dos agentes comunitários de saúde; territórios de responsabilização da atenção primária em saúde; territórios municipais; territórios mesorregionais; territórios estaduais; territórios interestaduais; território nacional; e microterritórios de vida da população. Considera o território como "parte da 
determinação social da saúde e de uma lógica racional de organização dos sistemas de saúde" (OPAS, 2010, p.49).

No contexto nacional, dentre as principais referências sobre a adaptação do conceito de sistema integrado de saúde à realidade brasileira, estão os trabalhos de Mendes $(2003 ; 2007 ; 2010)$. O autor criticou as diretrizes de regionalização do SUS na Noas (2001/02) por não considerarem aspectos mais específicos da gestão em saúde, tais como a economia de escala e escopo, a conformação de sistemas integrados de saúde, a microrregionalização cooperativa e as redes horizontais integradas de saúde:

A concepção piramidal vigente na NOAS SUS 01/02 será substituída pela concepção de uma rede horizontal integrada de serviços de saúde onde todos os pontos são importantes e formam um contínuo de atenção, ainda que se reconheça que há diferentes complexidades e densidades tecnológicas em cada uma dos pontos de atenção à saúde. Daí que não se operará com as categorias de atenção básica ampliada, média e alta complexidade, mas por níveis de atenção primário, secundário e terciário. O objetivo será desenvolver e implementar, em cada microrregião de saúde, um sistema integrado de serviços de saúde que articulasse os serviços de atenção primária e secundária à saúde. E que, estes, por sua vez, estarão articulados, numa macrorregião, com os serviços de atenção terciária à saúde. (MENDES, 2003, p.90-91).

O objetivo das redes de atenção à saúde no Brasil seria criar sistemas integrados de prestação de serviços de saúde com foco nas necessidades de saúde da população, na coordenação e integração do cuidado, na economia de escala e escopo, no fluxo de informações entre pacientes, prestadores e gestores, no uso de incentivos financeiros e organizacionais para criar governança, e na melhoria da qualidade dos serviços prestados (MENDES, 2007; 2010). Segundo o autor, a questão da concentração, do acesso e dos custos dos serviços também aparece como uma preocupação da literatura sobre redes de atenção, que indica a atenção primária de saúde $^{110}$ (APS) como principal meio para melhoria do acesso e redução dos custos.

\footnotetext{
${ }^{110}$ O conceito de Atenção Primária em Saúde foi definido pela Declaração de Alma Ata (1978): “Os cuidados primários de saúde são cuidados essenciais de saúde baseados em métodos e tecnologias práticas, cientificamente bem fundamentadas e socialmente aceitáveis, colocadas ao alcance universal de indivíduos e famílias da comunidade, mediante sua plena participação e a um custo que a comunidade e o país possam manter em cada fase de seu desenvolvimento, no espírito de autoconfiança e automedicação. Fazem parte integrante tanto do sistema de saúde do país, do qual constituem a função central e o foco principal, quanto do desenvolvimento social e econômico global da comunidade. Representam o primeiro nível de contato dos indivíduos, da família e da comunidade
} 
Mendes (2010, p.2300) define as redes de atenção à saúde como:

...organizações poliárquicas de conjuntos de serviços de saúde, vinculados entre si por uma missão única, por objetivos comuns e por uma ação cooperativa e interdependente, que permitem ofertar uma atenção contínua e integral a determinada população, coordenada pela atenção primária à saúde - prestada no tempo certo, no lugar certo, com o custo certo, com a qualidade certa e de forma humanizada -, e com responsabilidades sanitárias e econômicas por esta população.

Os elementos constituintes das RAS são: a população pela qual a rede se responsabiliza; a estrutura operacional e o modelo de atenção. As redes podem ser temáticas segundo as linhas de cuidado e as condições crônicas ou agudas das enfermidades, que servem como diretrizes para a estratégia de articulação e gerenciamento das unidades e dos atendimentos na rede (MENDES, 2007; LIMA et al., 2012).

A estratégia de conformação das redes de atenção à saúde no SUS objetiva a coordenação das ações a partir da atenção primária em saúde (APS) e a garantia da integralidade (cuidado contínuo). O estabelecimento da APS ou da Atenção Básica ${ }^{111}$ (AB) como coordenadora e principal porta de entrada do sistema visa superar a fragmentação das ações e serviços e diminuir as desigualdades em saúde, através da

com o sistema nacional de saúde, pelo qual os cuidados de saúde são levados o mais proximamente possível aos lugares onde pessoas vivem e trabalham, e constituem o primeiro elemento de um continuado processo de assistência à saúde."

111 “A Política Nacional de Atenção Básica considera os termos 'atenção básica' e 'Atenção Primária à Saúde', nas atuais concepções, como termos equivalentes”. (BRASIL MS, 2012e, p.22). “A atenção básica caracteriza-se por um conjunto de ações de saúde, no âmbito individual e coletivo, que abrange a promoção e a proteção da saúde, a prevenção de agravos, o diagnóstico, o tratamento, a reabilitação, a redução de danos e a manutenção da saúde com o objetivo de desenvolver uma atenção integral que impacte na situação de saúde e autonomia das pessoas e nos determinantes e condicionantes de saúde das coletividades. É desenvolvida por meio do exercício de práticas de cuidado e gestão, democráticas e participativas, sob forma de trabalho em equipe, dirigidas a populações de territórios definidos, pelas quais assume a responsabilidade sanitária, considerando a dinamicidade existente no território em que vivem essas populações. Utiliza tecnologias de cuidado complexas e variadas que devem auxiliar no manejo das demandas e necessidades de saúde de maior frequência e relevância em seu território, observando critérios de risco, vulnerabilidade, resiliência e o imperativo ético de que toda demanda, necessidade de saúde ou sofrimento devem ser acolhidos. É desenvolvida com o mais alto grau de descentralização e capilaridade, próxima da vida das pessoas. Deve ser o contato preferencial dos usuários, a principal porta de entrada e centro de comunicação da Rede de Atenção à Saúde. Orientase pelos princípios da universalidade, da acessibilidade, do vínculo, da continuidade do cuidado, da integralidade da atenção, da responsabilização, da humanização, da equidade e da participação social. A atenção básica considera o sujeito em sua singularidade e inserção sociocultural, buscando produzir a atenção integral." (BRASIL MS, 2012e, p.19-20). 
efetividade do atendimento e responsabilização das três instâncias de gestão do SUS pela APS (LAVRAS, 2011).

A integralidade depende necessariamente: da integração clínica (ações e serviços, conhecimentos e equipamentos médicos; coordenação das organizações); da integração normativa (valores e referências comuns para a interação das organizações); da integração sistêmica (coerência e eficiência no atendimento; conexão temporal e espacial entre os níveis de cuidado) e da integração funcional (estratégias de gestão, financiamento e informação) por meio das redes assistenciais, isto é, resulta da interdependência, cooperação e coordenação entre diferentes atores e organizações para realizar um projeto coletivo, como resolver os problemas de saúde de uma dada população, em uma dada região (CONTANDRIOPOULOS et al., 2001; HARTZ \& CONTANDRIOPOULOS, 2004). As redes teriam uma dupla leitura: (i) como estrutura organizacional de produção de serviços e (ii) como dinâmica de atores e organizações "em permanente renegociação de seus papéis, favorecendo novas soluções para velhos problemas num contexto de mudanças e compromissos mútuos" (HARTZ \& CONTANDRIOPOULOS, 2004, p.334).

As redes de atenção à saúde seriam uma expressão política de interesses comuns compartilhados por diversos atores e instituições, que se organizam como rede em prol de objetivos claros e pactuados (MENDES, 2007; FLEURY \& OUVERNEY, 2007).

Nesse sentido, Santos \& Andrade $(2007,2011)$ utilizam o conceito de redes assistenciais interfederativas, considerando que a conformação das redes de atenção à saúde, incluindo seus objetivos, linhas de cuidado, protocolos clínicos, financiamento, logística e critérios de incorporação tecnológica, deve ser negociada pelos três entes federados, nos espaços colegiados de gestão do SUS. As redes assistenciais interfederativas partem do conceito de redes de atenção à saúde, mas não se limitam a estas. Trata-se de compreender que a conformação das RAS depende das redes interfederativas, que se caracterizam "pela necessidade de haver, no SUS, 'gestão' intergovernamental, e não apenas relações entre os governos" (SANTOS \& ANDRADE, 2011, p.1676).

A rede interfederativa engloba a rede de serviços, mas não é esta; a rede de serviços tem postos de saúde, hospitais, tecnologias, profissionais, 
unidades; a rede interfederativa tem colegiados e agentes políticos que "deliberam sobre o sistema". A rede interfederativa é o todo; a rede de serviços, uma parte desse todo. (...) A rede interfederativa comporta em si as redes de serviços em todas as suas formas (...). Ela é a interconexão dos entes políticos responsáveis pela saúde (ações e serviços), que devem, conjuntamente, em espaços como os colegiados, decidir de comum acordo todas as questões referentes à saúde, como planejamento integrado, financiamento compartilhado, prestação de serviços em rede, fiscalização. Para manter a unicidade do sistema, há que se definir conjuntamente o padrão de integralidade, critérios de incorporação tecnológica, regulamentos técnicos, protocolos clínicos, critérios para controle e avaliação, entre outros fatores. A rede interfederativa deve ter como abrangência o Estado federal (nacional) com seus recortes políticos (União, estados, Distrito Federal e municípios) e pode, ainda, se organizar por regiões (interestadual, metropolitana, regional e intermunicipal). (...) Além do mais, não seria inadequado dizer que a rede interfederativa se confunde com o próprio Sistema Único de Saúde, por ser este concebido como uma "rede de entes políticos, interdependentes na gestão e no financiamento da saúde". (SANTOS \& ANDRADE, 2011, p.1677).

Verifica-se que a conceituação das redes de atenção à saúde tem inspiração não apenas nas teorias econômicas de mercado, mas também na teoria dos "espaços de fluxos", conforme definido por Manuel Castells (SANTOS L, 2008). O dado informacional aparece como variável-chave, sendo fundamental a utilização de tecnologias de informação para a estruturação e o funcionamento das RAS. Há uma sobrevalorização da noção de rede, inclusive, considerando-se que "a administração pública contemporânea reconhece a necessidade de atuar como se fora um Estadorede, um Estado negociador-consensual" (SANTOS L, p.33).

Uma das principais diferenças da adaptação da proposta de redes, forjada no sistema americano, para países com sistemas universais de saúde, é a questão da regionalização, que implica universalidade e diminuição das desigualdades (KUSCHNIR \& CHORNY, 2010).

Enquanto a rede se destaca como estratégia de atuação do Mercado na saúde, a regionalização se caracteriza como estratégia de ação do Estado no planejamento do sistema. As redes enfatizam o caráter gerencial dos sistemas de saúde (sistema de gestão, integração econômica vertical e horizontal, economia de escala e escopo, coordenação), enquanto que a regionalização enfatiza o caráter público, universal e equitativo do planejamento em saúde. 
Para o sistema americano, por exemplo, não se coloca a questão da regionalização - intrinsecamente derivada dos princípios de universalidade e equidade dos sistemas universais. Os sistemas integrados americanos são, por definição, destinados aos que podem pagar, com planos diferenciados que pressupõem acesso desigual e naturalmente não incorporam as questões da saúde pública e da ação sobre os condicionantes sociais, próprias do Estado. Os sistemas nacionais, ao contrário, não podem abdicar de sua responsabilidade de garantia do direito e a organização de redes regionalizadas constitui-se num instrumento para ampliação do acesso e diminuição de desigualdades. (KUSCHNIR \& CHORNY, 2010, p.2308).

Na política nacional de saúde brasileira, as noções e diretrizes das redes e da regionalização do SUS evoluíram ao longo do tempo, aproximando essas duas estratégias e tornando-as cada vez mais interdependentes.

\subsection{Redes e a regionalização do SUS}

A Constituição Federal cita no Art. 198 que "as ações e serviços públicos de saúde integram uma rede regionalizada e hierarquizada". A Lei Orgânica da Saúde 8.080 de 1990 cita a rede regionalizada e hierarquizada e a diretriz da integralidade de assistência, que ressalta a necessidade de integração em rede ao ser definida como "um conjunto articulado e contínuo das ações e serviços preventivos e curativos" (art. 7).

Mas a institucionalização da construção de redes assistenciais regionalizadas só começou a se concretizar na política nacional a partir da edição da Norma Operacional de Assistência à Saúde (Noas), em 2001.

A Noas, buscando a conformação de sistemas funcionais e resolutivos de saúde, utilizou o termo rede regionalizada e hierarquizada de serviços e focou o estabelecimento de mecanismos e fluxos de referência e contra-referência intermunicipais para garantir a integralidade assistencial e a integração das ações e serviços numa dada região de saúde. Apesar dos critérios da regionalização incluirem características demográficas, socioeconômicas e epidemiológicas, além do rol de serviços, o desenho regional era pré-determinado pela existência de certa capacidade instalada em média complexidade e de fluxos intermunicipais. Assim, os municípios polo, concentradores da oferta e dos fluxos, ganharam centralidade na definição das 
redes assistenciais e no desenho regional. A responsabilidade de conformação das redes regionalizadas e hierarquizadas recaiu principalmente sobre os estados, enquanto os municípios ficaram responsáveis pela organização da rede de atenção básica no seu território.

Com a Noas, a rede assistencial regionalizada e hierarquizada aparece como o principal elemento estruturador do recorte regional do SUS. Entretanto, podem-se apontar duas limitações em relação a isso. Primeiro, a região de saúde, mesmo que definida a partir da organização das redes assistenciais, não se resume ao funcionamento destas. Há uma série de outros elementos que influenciam direta ou indiretamente a evolução da situação de saúde, da organização das redes, da capacidade de proposição e execução das políticas e da capacidade de oferta, gestão, financiamento e organização do sistema público de saúde no território, e que devem ser considerados no planejamento regional da saúde. O foco prioritário nas redes ajudou a firmar uma visão de região de saúde muito vinculada à capacidade de oferta de ações e serviços e aos fluxos assistenciais decorrentes dessa oferta, hierarquizados e regulados conforme a complexidade dos serviços. Segundo, chama a atenção o fato de não haver a elaboração de um conceito de rede regionalizada e hierarquizada de saúde e tampouco diretrizes específicas de organização, gestão, financiamento e logística das mesmas, no momento de implantação da regionalização proposta pela Noas. Esta diretriz foi publicada no período da globalização, em que uma das características mais marcantes foi a excessiva valorização das redes tecnológicas, das ações em redes globais, da comunicação em rede (CASTELLS, 1999; DIAS, 2007). O termo rede foi exaustivamente discutido em várias áreas das ciências durante a década de 1990 e poderia ter resultado em maior influência sobre o planejamento regional do SUS. Ao mesmo tempo, havia documentos e experiências nacionais (estados) e internacionais relevantes sobre a conformação de redes assistenciais de saúde, que poderiam ter embasado a elaboração de um conceito de rede mais específico para orientar a regionalização do SUS e a política nacional de saúde. A ausência de diretrizes e conceitos de redes no momento de institucionalização da regionalização do SUS (Noas) talvez possa ser explicada pela baixa capacidade de planejamento regional e financiamento estatal e pela dificuldade de valorização das políticas públicas universais durante a vigência da agenda neoliberal, além do 
incentivo à descentralização municipalista (União-município), que agravou a fragmentação das políticas e do sistema de saúde, incentivou a competitividade entre os governos e acelerou a reprodução das desigualdades territoriais.

$\mathrm{Na}$ Noas, a rede regionalizada e hierarquizada aparece estreitamente ligada à capacidade de oferta de serviços e à racionalidade da regulação dos fluxos assistenciais, e a rigidez normativa dificulta a consideração da complexidade dos fluxos e dos diversos interesses e conflitos existentes entre os agentes e instituições envolvidos na produção e na regulação dos serviços. Os fluxos assistenciais em si não estruturam redes, da mesma forma que o sistema de regulação também não estrutura redes, porque estas necessitam de uma série de mecanismos de coordenação, instituições, financiamento, informação, gestão, regulação, hierarquização e tecnologias, constituindo subsistemas técnicos e políticos assistenciais.

Em 2001, a Portaria n ${ }^{\circ} 1.020$ estabeleceu os objetivos gerais da Programação Pactuada e Integrada - PPI da assistência, visando à construção das redes regionalizadas e hierarquizadas. Considerando as diretrizes definidas pela Noas, entre 2001 e 2005, uma série de portarias ministeriais estabeleceram normas e incentivos federais para a conformação de Redes Estaduais de Assistência regionalizadas, de acordo com as especialidades médicas, níveis de atenção e público alvo (Hanseníase; Cardiovascular; Nefrologia; Saúde Auditiva; Neurologia; Serviços de Atendimento Móvel à Urgência - Samu; Oftalmologia; Atenção Cardiovascular de Alta Complexidade; Reprodução Humana Assistida; Oncológica; Saúde do Idoso; e Serviços de Reabilitação para Pessoas com Deficiência).

A Rede de Serviços de Atendimento Móvel à Urgência - Samu teve prioridade na agenda federal a partir de 2003. De início, focou a implantação de serviços de abrangência municipal e, posteriormente, em 2008, buscou a abrangência regional, alcançando cobertura de $50 \%$ da população brasileira em 2009 (MACHADO et al., 2011c).

Em 2006, a publicação do Pacto pela Saúde também não veio embasada por uma definição de rede de saúde ou diretrizes específicas para sua estruturação. Contudo, o documento traz uma nova nomenclatura: rede de atenção à saúde e suas variações (redes regionalizadas de atenção à saúde; rede regional de ações e serviços 
de atenção à saúde). $\mathrm{O}$ termo rede regionalizada e hierarquizada de ações e serviços aparece como referência à Constituição Federal de 1988, nas considerações da Portaria 399/06, e poucas vezes são citadas suas variações (redes regionais hierarquizadas estaduais e rede de ações e serviços de saúde). O Caderno da PPI fala também em redes funcionais (BRASIL MS, 2006b).

A mudança de nomenclatura para rede de atenção à saúde aponta o início da influência, na política nacional brasileira, dos debates internacionais promovidos pela OMS sobre a questão dos sistemas integrados de saúde e das redes integradas de saúde. O Pacto expressa um processo de mudança conceitual na política nacional, que só iria se consolidar com a publicação da Portaria 4.279, em 2010, e do Decreto 7.508, em 2011.

A questão mais importante no Pacto pela Saúde diz respeito ao uso do termo rede de cooperação entre os três entes federados (Portaria 399, item 4 Planejamento do SUS, subitem 4.2) ao se referir à necessidade de maior coordenação e cooperação entre as esferas governamentais na gestão regional do SUS. A rede de atenção à saúde é pensada a partir da capacidade instalada, das necessidades em saúde e dos fluxos assistenciais existentes, mas, o foco principal recai sobre a capacidade de negociação e cooperação intergovernamental. Esta é a grande novidade introduzida pelo Pacto para pensar as redes e as regiões de saúde, corroborando com a principal inovação introduzida pela norma em relação à regionalização - a criação dos Colegiados de Gestão Regional (CGR).

A ausência de definições e mecanismos específicos para a integração das ações e serviços em redes de atenção talvez possa ser explicada pelo fato das diretrizes de regionalização do Pacto terem focado prioritariamente a questão do funcionamento do federalismo brasileiro. Procurando fugir da rigidez normativa da Noas, a integralidade e a integração das ações e serviços dependeriam sobremaneira da articulação regional entre os gestores estaduais e municipais, portanto, da existência de espaços de negociação regionais (CGRs). O próprio desenho da região de saúde resultaria das negociações intergovernamentais. Há uma sobrevalorização da base política da regionalização em relação à base técnica e normativa (instrumentos de planejamento, redes assistenciais e diagnósticos regionais). 
O principal elemento estruturador do recorte regional do SUS no território continuou sendo a constituição de redes, mas estas são tanto políticas, quanto técnico-assistenciais. Isso reflete a orientação geral da política nacional de ampliar e consolidar parcerias intergovernamentais para a elaboração e efetivação dos projetos políticos, no contexto de retomada do papel do Estado na elaboração de uma agenda desenvolvimentista e de estratégias de planejamento regional.

Em 2006, o Ministério da Saúde continuou editando portarias para a conformação das redes assistenciais regionalizadas e criou um grupo técnico de assessoramento para o planejamento, avaliação e aprovação da rede de atenção oncológica nos estados. Mas o fato mais importante foi o início das negociações do MS com o Banco Mundial para a contratação do Projeto QualiSUS-Rede, voltado para investimentos nas redes de atenção à saúde no SUS (BANCO MUNDIAL, 2008; BRASIL SF, 2009).

Em 2007, o MS criou a Diretoria de Articulação de Redes de Atenção à Saúde (DARAS/SAS/MS), posteriormente denominada, em 2011, por Departamento de Articulação de Redes de Atenção à Saúde, continuando com as mesmas funções ${ }^{112}$.

Em 2008, o MS elaborou um documento-base sobre a implantação das redes de atenção no país: "Redes regionalizadas de Atenção à Saúde: contexto, premissas, diretrizes gerais, agenda tripartite para discussão e proposta de metodologia para apoio à implementação" (BRASIL MS, 2008d). A publicação tinha como objetivo

\footnotetext{
112 "Nossa missão é articular os atores sociais implicados na organização das RAS, induzindo e apoiando os processos para suas conformações nos territórios, visando a integralidade da gestão e a integralidade do cuidado, com garantia do acesso e da qualidade da atenção à saúde para os usuários do SUS. Ao DARAS/SAS/MS compete: • Promover a integração da atenção básica aos serviços de urgência e emergência, à atenção especializada e às ações de vigilância em saúde visando à melhoria da gestão clínica, promoção e prevenção da saúde e uso racional de recursos; • Promover ações da rede de atenção à saúde numa integração sistêmica de serviços de saúde com provisão de atenção contínua, integral, de qualidade, humanizada, com acesso, equidade, eficácia clínica e sanitária e eficiência econômica; - Proceder à análise técnica de projetos apresentados por instituições que tenham por objeto ações/atividades voltadas para organização de redes de atenção à saúde; • Apoiar técnica e financeiramente Estados, Municípios e o Distrito Federal na organização das ações de rede de atenção à saúde; • Desenvolver mecanismos de gestão, sistemas, controle e avaliação das ações de rede de atenção à saúde para monitoramento das ações planejadas; - Apoiar as ações de contratualização e pactuação intra e intersetoriais; - Apoiar o desenvolvimento de mecanismos inovadores que fortaleçam a organização de sistemas de saúde e a capacidade de gestão do SUS nas três esferas de governo; • Monitorar e avaliar as ações voltadas à organização e implementação de redes de atenção à saúde; e • Promover a interface entre os financiadores e as unidades executoras das ações previstas para os projetos do Departamento". (www.saude.gov.br. Acesso em março de 2013).
} 
formular conceitos e estratégias para a adaptação do modelo de sistemas integrados de saúde para a realidade brasileira e para cada uma das regiões de saúde, procurando fortalecer as relações de complementaridade, interdependência e a articulação funcional e sistêmica, através da organização e gestão em rede. O documento previa fundamentar o processo de regionalização na organização das redes regionalizadas de atenção à saúde, orientando a construção de sistemas integrados no espaço regional.

No mesmo ano, portarias ministeriais definiram as diretrizes para a implementação regionalizada das redes de atenção às urgências e Serviços de Atendimento Móvel à Urgência (SAMU). Em 2009, a Portaria 1020 estabeleceu as diretrizes para a implantação do componente pré-hospitalar fixo - Unidades de Pronto Atendimento (UPA) e Salas de Estabilização (SE) - visando a organização de redes loco-regionais de atenção integral às urgências.

Em 2010, o Ministério da Saúde institucionalizou as redes de atenção à saúde na política nacional, através da Portaria $\mathrm{n}^{\circ} 4.279$, que estabeleceu as diretrizes para a organização da rede de atenção à saúde no SUS, com base nas teorias e proposições apresentadas pelos documentos internacionais, pelo MS e pelos trabalhos de Mendes (2007).

O modelo de atenção à saúde do SUS foi apontado como insuficiente para dar conta dos desafios sanitários atuais, caracterizado pela "tripla carga de doenças", isto é, pela coexistência doenças infecciosas e aquelas resultantes do empobrecimento, problemas de saúde que resultam de causas externas (violência, por exemplo) e as doenças crônicas e degenerativas. A Portaria apontou a complexidade da interrelação entre os fatores para construção das redes de atenção à saúde (acesso, escala, escopo, qualidade, custo e efetividade) e a fragmentação do SUS, que se expressa por:

(1) lacunas assistenciais importantes; (2) financiamento público insuficiente, fragmentado e baixa eficiência no emprego dos recursos, com redução da capacidade do sistema de prover integralidade da atenção à saúde; (3) configuração inadequada de modelos de atenção, marcada pela incoerência entre a oferta de serviços e a necessidade de atenção, não conseguindo acompanhar a tendência de declínio dos problemas agudos e de ascensão das condições crônicas; (4) fragilidade na gestão do trabalho com o grave problema de precarização e carência de profissionais em número e alinhamento com a política pública; (5) a pulverização dos 
serviços nos municípios; e (6) pouca inserção da Vigilância e Promoção em Saúde no cotidiano dos serviços de atenção, especialmente na Atenção Primária em Saúde (APS). (BRASIL, 2010, p.02)

As redes são "estratégias para superar a fragmentação da atenção e da gestão nas regiões de saúde e aperfeiçoar o funcionamento político-institucional do SUS”, e de qualificação do cuidado em saúde (BRASIL, 2010, p.01). A conformação de redes de atenção à saúde é uma estratégia de reestruturação do sistema e têm fundamento no arcabouço normativo do SUS.

A rede de atenção à saúde é definida como:

Arranjos organizativos de ações e serviços de saúde, de diferentes densidades tecnológicas, que integradas por meio de sistemas de apoio técnico, logístico e de gestão, buscam garantir a integralidade do cuidado. (...) Caracteriza-se pela formação de relações horizontais entre os pontos de atenção com o centro de comunicação na Atenção Primária à Saúde (APS), pela centralidade nas necessidades em saúde de uma população, pela responsabilização na atenção contínua e integral, pelo cuidado multiprofissional, pelo compartilhamento de objetivos e compromissos com os resultados sanitários e econômicos. Fundamenta-se na compreensão da APS como primeiro nível de atenção, enfatizando a função resolutiva dos cuidados primários sobre os problemas mais comuns de saúde e a partir do qual se realiza e coordena o cuidado em todos os pontos de atenção. Os pontos de atenção à saúde são entendidos como espaços onde se ofertam determinados serviços de saúde, por meio de uma produção singular. (BRASIL, 2010, p.04)

O objetivo é promover a integração sistêmica de ações e serviços de saúde com continuidade da atenção. Os pontos de atenção à saúde ${ }^{113}$ são os nós (fixos) das redes, diferenciando-se em função da densidade tecnológica que abrigam e das especialidades que ofertam. Os sistemas logísticos articulam os fluxos das redes (sistema informacional, regulação e transporte sanitário), igualmente importantes para garantir a continuidade do cuidado.

A integração do sistema e adequação do modelo de atenção necessita de uma articulação cooperativa entre as instâncias de gestão do SUS, visando a "associação

\footnotetext{
113 "São exemplos de pontos de atenção à saúde: os domicílios, as unidades básicas de saúde, as unidades ambulatoriais especializadas, os serviços de hemoterapia e hematologia, os centros de apoio psicossocial, as residências terapêuticas, entre outros. Os hospitais podem abrigar distintos pontos de atenção à saúde: o ambulatório de pronto atendimento, a unidade de cirurgia ambulatorial, o centro cirúrgico, a maternidade, a unidade de terapia intensiva, a unidade de hospital/dia, entre outros." (BRASIL, 2010, p.04)
} 
fina da técnica e da política” para garantir os recursos necessários (BRASIL, 2010, p.03).

A Portaria 4279 define o sistema de governança das redes:

A governança é definida pela Organização das Nações Unidas como o exercício da autoridade política, econômica e administrativa para gerir os negócios do Estado. Constitui-se de complexos mecanismos, processos, relações e instituições através das quais os cidadãos e os grupos sociais articulam seus interesses, exercem seus direitos e obrigações e mediam suas diferenças (RONDINELLI, 2006). (BRASIL, 2010, p.13)

Este sistema conta com o protagonismo dos Colegiados de Gestão Regional $^{114}$ (atuais Comissões Intergestores Regionais - CIR), apontando, inclusive, a necessidade de fortalecimento das mesmas para que se realize uma "governança solidária nas regiões de saúde" (compartilhamento de estruturas administrativas, de recursos, sistema logístico e apoio, e processo contínuo de monitoramento e avaliação da Rede de Atenção à Saúde).

A governança da RAS é entendida como a capacidade de intervenção que envolve diferentes atores, mecanismos e procedimentos para a gestão regional compartilhada da referida rede. Nesse contexto, o Colegiado de Gestão Regional desempenha papel importante, como um espaço permanente de pactuação e co-gestão solidária e cooperativa onde é exercida a governança, a negociação e a construção de consensos, que viabilizem aos gestores interpretarem a realidade regional e buscarem a conduta apropriada para a resolução dos problemas comuns de uma região. Exercer uma governança solidária nas regiões de saúde implica o compartilhamento de estruturas administrativas, de recursos, sistema logístico e apoio, e de um processo contínuo de monitoramento e avaliação da Rede de Atenção à Saúde. Assim, a governança da RAS é diferente da gerência dos pontos de atenção à saúde, dos sistemas de apoio e dos logísticos. O exercício da governança implica, ainda, o enfrentamento de questões políticas e estruturais do processo de regionalização, como as relações federativas, as relações públicoprivadas, as capacidades internas de gestão, a sustentabilidade financeira, a regulação da atenção e o estabelecimento de padrões de qualidade para a provisão de serviços (públicos e privados), bem como os padrões de gestão e desempenho das unidades de saúde, entre outros. (BRASIL, 2010, p.13).

114 “O processo de Planejamento Regional, discutido e desenvolvido no CGR, estabelecerá as prioridades de intervenção com base nas necessidades de saúde da região e com foco na garantia da integralidade da atenção, buscando a maximização dos recursos disponíveis." (BRASIL, 2010, p.14) 
A Portaria prevê a participação da população no processo de contratualização, através da criação de mecanismos e instrumentos para o controle social das redes, tais como fóruns regionais e pesquisas de satisfação do usuário, que podem subsidiar o monitoramento e avaliação das políticas de saúde nas regiões de saúde.

O compromisso em torno dos objetivos comuns é formalizado através da contratualização entre os entes reguladores/financiadores e os prestadores de serviços. A contratualização ou contratos de gestão foram definidos pela Portaria 4279 como:

\begin{abstract}
...modo de pactuação da demanda quantitativa e qualitativa na definição clara de responsabilidades, de objetivos de desempenho, incluindo tanto os sanitários, quanto os econômicos, resultando dessa negociação um compromisso explícito entre ambas as partes. (...) adotam três áreas de aplicação que são: cuidados primários, atenção especializada (ambulatorial e hospitalar) e cuidados de urgência e emergência. (BRASIL, 2010, p.04-05)
\end{abstract}

O novo modelo de contrato de gestão supera o foco na população isolada por hospitais ou centros de saúde e passa para uma contratualização no âmbito da região de saúde, "seguindo critérios de adscrição da população estratificada por grau de risco, e abordando os diversos estabelecimentos de saúde em termos de uma rede de cuidados" (BRASIL, 2010, p.05). O novo modelo deve basear-se na noção de suficiência, definida como "conjunto de ações e serviços disponíveis em quantidade e qualidade para atender às necessidades de saúde da população" (BRASIL, 2010, p.06).

O documento traz uma definição de região de saúde vinculada à organização das redes, trata-se do limite geográfico de abrangência das redes de atenção à saúde ou abrangência da base populacional atendida pelas redes. O objetivo de identificar as regiões de saúde ou de abrangência é fundamentar as estratégias de organização das redes de atenção à saúde e identificar a área geográfica e população sobresponsabilidade das mesmas.

A Portaria 4279 não substituiu a definição de região de saúde do Pacto pela Saúde, pelo contrário, reafirmou que as regiões eram definidas por este documento. Entretanto, a Portaria criou uma segunda forma de "enxergar" a região de saúde (Quadro 4). 
Na definição de região de saúde, a Portaria 4279 associa o limite geográfico regional ao limite de abrangência das redes de atenção à saúde e classifica o rol de ações e serviços regionais "como arranjos produtivos conformados segundo as densidades tecnológicas singulares", sendo a atenção primária em saúde (APS) o nível de menor densidade, a atenção secundária o nível de densidade tecnológica intermediária e a atenção terciária o nível de maior densidade tecnológica. Nos critérios para a regionalização, a Portaria 4279 inclui aqueles de acessibilidade e escala econômica. Dentre os objetivos da regionalização, abarca a organização das redes de atenção à saúde, a identificação da população sob-responsabilidade das mesmas, a integralidade e a continuidade do cuidado e a governança das redes no espaço regional. Neste caso, indica os Colegiados de Gestão Regional como fóruns de exercício da governança das redes. No que se refere às possíveis divisões regionais do SUS, a Portaria 4279 sugere que os limites regionais coincidam com a base populacional sob-responsabilidade das redes de atenção à saúde, a acessibilidade e a escala de produção e acesso, sendo que as redes podem abranger uma ou mais regiões de saúde. Finalmente, em relação aos instrumentos de planejamento regional do SUS, a Portaria 4279 inclui aqueles específicos de organização e gestão das redes de atenção à saúde: diretrizes clínicas; linhas de cuidado; modelo de atenção; auditoria clínica; lista de espera; e sistema logístico de informação, regulação e transporte sanitário. Além disso, indica que o exercício da governança $^{115}$ das redes de atenção à saúde deve enfrentar questões políticas e estruturais do processo de regionalização: as relações federativas, as relações público-privadas, as capacidades internas de gestão, o financiamento, a regulação da atenção e o estabelecimento de padrões de qualidade, de gestão e desempenho das unidades de saúde.

\footnotetext{
115 "No processo de governança são utilizados instrumentos e mecanismos de natureza operacional, tais como: roteiros de diagnóstico, planejamento e programações regionais, sistemas de informação e identificação dos usuários, normas e regras de utilização de serviços, processos conjuntos de aquisição de insumos, complexos reguladores, contratos de serviços, sistemas de certificação/acreditação, sistema de monitoramento e avaliação, comissões/câmaras técnicas temáticas, etc. Alguns desses mecanismos podem ser viabilizados por intermédio de consórcio público de saúde, que se afigura como uma alternativa de apoio e fortalecimento da cooperação interfederativa para o desenvolvimento de ações conjuntas e de objetivos de interesse comum, para melhoria da eficiência da prestação dos serviços públicos e operacionalização da Rede de Atenção à Saúde.” (BRASIL, 2010, p.14)
} 
Quadro 4 - Duas formas de “enxergar” a regionalização do Sistema Único de Saúde: o Pacto pela Saúde e a Portaria 4.279/2010

\begin{tabular}{|c|c|c|}
\hline & Pacto pela Saúde (2006) & Portaria 4.279 (2010) \\
\hline $\begin{array}{l}\text { Definição de } \\
\text { região }\end{array}$ & $\begin{array}{l}\text { Recortes territoriais inseridos em espaços geográficos contínuos, } \\
\text { não necessariamente coincidentes com a divisão administrativa do } \\
\text { estado } \\
\text { Elementos: limite geográfico, população usuária, fluxos } \\
\text { assistenciais, ações e serviços de AB, MC e VS, Colegiados de } \\
\text { Gestão Regional. }\end{array}$ & $\begin{array}{l}\text { Limite geográfico de abrangência das redes de atenção à } \\
\text { saúde. } \\
\text { Elementos: limite geográfico, população usuária, fluxos } \\
\text { assistenciais, rol de ações e serviços (APS, secundária e } \\
\text { terciária), Colegiados de Gestão Regional. }\end{array}$ \\
\hline Critérios & $\begin{array}{l}\text { Identidades culturais, econômicas e sociais, características } \\
\text { epidemiológicas, existência de redes nas áreas de comunicação, } \\
\text { infraestrutura, transportes e saúde. Deve estar garantido o } \\
\text { desenvolvimento da atenção básica (AB) da assistência e parte da } \\
\text { média complexidade (MC), assim como as ações básicas de } \\
\text { vigilância em saúde (VS). } \\
\text { Considera as demandas da população. } \\
\text { Cooperação intergovernamental. }\end{array}$ & $\begin{array}{l}\text { Amplo conhecimento das necessidades, preferências e grau } \\
\text { de risco de uma dada população, rol de ações e serviços } \\
\text { ofertados (atenção primária - APS, secundária e terciária), } \\
\text { acessibilidade escala para a conformação dos serviços. } \\
\text { Critérios de acessibilidade e escala. }\end{array}$ \\
\hline Objetivos & $\begin{array}{l}\text { Atender às demandas das populações dos municípios a elas } \\
\text { vinculados, garantindo o acesso, a equidade e a integralidade do } \\
\text { cuidado com a saúde local. Diminuir as desigualdades } \\
\text { socioespaciais de universalização da saúde, superar os limites do } \\
\text { modelo de descentralização municipalista da saúde e fortalecer o } \\
\text { papel dos estados no planejamento e na coordenação / } \\
\text { cooperacãa intergovernamental. }\end{array}$ & $\begin{array}{l}\text { Organização das redes de atenção à saúde, identificação da } \\
\text { área geográfica e a população sob-responsabilidade das } \\
\text { mesmas e integralidade e continuidade do cuidado. } \\
\text { Governança das redes. }\end{array}$ \\
\hline Responsáveis & $\begin{array}{l}\text { Secretarias Estaduais de Saúde } \\
\text { Secretarias Municipais de Saúde } \\
\text { Colegiados de Gestão Regional } \\
\text { CIB } \\
\text { Comissão Intergestores Tripartite (CIT) (no caso de regiões nas } \\
\text { áreas de fronteira internacional) }\end{array}$ & $\begin{array}{l}\text { Secretarias Estaduais de Saúde } \\
\text { Secretarias Municipais de Saúde } \\
\text { Colegiados de Gestão Regional (participam da governança } \\
\text { das redes) } \\
\text { CIB }\end{array}$ \\
\hline
\end{tabular}




\begin{tabular}{|l|l|l|}
\hline $\begin{array}{l}\text { Desenhos } \\
\text { regionais }\end{array}$ & $\begin{array}{l}\text { As Regiões de Saúde podem assumir diferentes desenhos, } \\
\text { intraestaduais e interestaduais. "Regionalização viva" }\end{array}$ & $\begin{array}{l}\text { Abrangência da base populacional sob-responsabilidade das } \\
\text { redes de atenção à saúde, acessibilidade e escala } \\
\text { (Redes de atenção à saúde podem abranger uma ou mais regiões } \\
\text { de saúde) }\end{array}$ \\
\hline $\begin{array}{l}\text { Instrumentos } \\
\text { de } \\
\text { planejamento } \\
\text { regional }\end{array}$ & $\begin{array}{l}\text { Termos de compromisso de gestão } \\
\text { PPI, PDR, PDI } \\
\text { Indicadores de monitoramento } \\
\text { Complexos reguladores } \\
\text { Financiamento por blocos (Atenção básica, Atenção de média e } \\
\text { alta complexidade, Vigilância em Saúde, Assistência Farmacêutica } \\
\text { e Gestão do SUS) } \\
\text { Normas internacionais (regiões de fronteira) }\end{array}$ & $\begin{array}{l}\text { PDR } \\
\text { PDI } \\
\text { Diretrizes clínicas } \\
\text { Linhas de cuidado } \\
\text { Modelo de atenção } \\
\text { Auditoria clínica } \\
\text { Lista de espera } \\
\text { Sistema logístico de informação, regulação e transporte } \\
\text { sanitário }\end{array}$ \\
\hline
\end{tabular}

Adaptado de Ibañez \& Albuquerque (2012, p.123-125). 
A Rede de Atenção à Saúde (RAS) ganhou institucionalidade a partir dos conceitos e das diretrizes definidos pela Portaria 4279. Por um lado, isso representou um ganho para a regionalização do SUS, já que esta se baseia fundamentalmente na estruturação das redes assistenciais de saúde. Não existe região sem rede. Mas, por outro lado, as RAS introduziram novos elementos para se pensar a regionalização do SUS, criando certa "confusão" entre os conceitos de rede e região no planejamento da saúde.

Em 2011, o Decreto 7.508 procurou dialogar duas dimensões da conformação das RAS - a técnica e a política - a partir da organização regional do sistema. Incorporou a RAS nas diretrizes de organização e regionalização do SUS, focando um rol mais detalhado da oferta de ações e serviços, os critérios de acessibilidade e escala e a conformação das redes de atenção à saúde nas regiões. Ao mesmo tempo, ressaltou o fator político para se referir às redes, introduzindo um novo termo, a rede interfederativa de atenção à saúde. Conforme o Art. 33 (seção II): "O acordo de colaboração entre os entes federativos para a organização da rede interfederativa de atenção à saúde será firmado por meio de Contrato Organizativo da Ação Pública da Saúde (Coap)". Dentre os objetivos da regionalização aparece a governança das redes, sendo as Comissões Intergestores Bipartite (CIB) e Regionais (CIR) os espaços privilegiados para essa finalidade.

A Relação Nacional de Medicamentos Essenciais (Rename) e a Relação Nacional de Ações e Serviços de Saúde (Renases) criaram parâmetros para os conceitos de integralidade da atenção e de acesso universal e igualitário aos serviços. As Comissões Intergestores e o Coap reforçaram os instrumentos de gestão compartilhada do SUS. Contudo, o Decreto não enfatizou a questão do financiamento para a regionalização das redes interfederativas de atenção à saúde, que depende "de novos arranjos financeiros" (IPEA, 2012, p.81). No Coap, os indicadores e metas referem-se às redes temáticas priorizadas pela política nacional, mas não estabelecem um vínculo direto com o financiamento das três esferas governamentais (BRASIL MS, 2012). O principal instrumento de indução federal para a conformação das RAS tem sido as portarias das redes temáticas, onde são definidos os investimentos nos componentes das redes. 
$\mathrm{Na}$ fase da regionalização contratualizada, a questão regional se vinculou fortemente à estruturação das redes de atenção à saúde no território - priorizadas pela política nacional de saúde, através da implantação das redes temáticas.

Em 2011, o governo federal elencou as redes de temáticas prioritárias ${ }^{116}$ : Rede Cegonha, Rede de Atenção Psicossocial e Rede de Urgência e Emergência. Posteriormente, foram definidas mais duas redes: Rede de Cuidado à Pessoa com Deficiência e a Rede de Atenção às Doenças e Condições Crônicas.

Essas redes também passaram a integrar os compromissos do governo com a redução das desigualdades nas regiões Nordeste e Amazônia Legal, a exemplo da Rede Cegonha. As diretrizes operacionais para a conformação das redes temáticas nas regiões de saúde, podem ser observadas no Quadro 5, a seguir.

\footnotetext{
116 • Rede Cegonha, que tem um recorte de atenção à gestante e de atenção à criança até 24 meses;

- Rede de Atenção às Urgências e Emergências: Saúde Toda Hora;

- Rede de Atenção Psicossocial (com prioridade para o Enfrentamento do Álcool, Crack, e outras Drogas);

- Rede de Atenção às Doenças e Condições Crônicas: iniciando-se pelo câncer (a partir da intensificação da prevenção e controle do câncer de mama e colo do útero);

- Rede de Cuidado à Pessoa com Deficiência.
} 
Quadro 5 - Diretrizes nacionais para conformação das redes temáticas nas regiões de saúde (Brasil, 2011-2013)

\begin{tabular}{|c|c|c|c|c|c|}
\hline & Rede Cegonha & $\begin{array}{l}\text { Rede de atenção às urgências } \\
\text { e emergências (UE) }\end{array}$ & $\begin{array}{l}\text { Rede de atenção } \\
\text { psicossocial }\end{array}$ & $\begin{array}{l}\text { Rede de Cuidado à } \\
\text { Pessoa com Deficiência }\end{array}$ & $\begin{array}{c}\text { Rede de Atenção à } \\
\text { Saúde das Pessoas com } \\
\text { Doenças Crônicas } \\
\end{array}$ \\
\hline 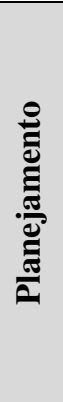 & $\begin{array}{l}\text { Programação dos } \\
\text { componentes da rede } \\
\text { conforme matriz } \\
\text { diagnóstica das } \\
\text { necessidades regionais. } \\
\text { Desenho regional da } \\
\text { rede. }\end{array}$ & $\begin{array}{l}\text { Regionalização do } \\
\text { atendimento às UE com } \\
\text { articulação das diversas redes } \\
\text { de atenção e acesso regulado } \\
\text { aos serviços de saúde. } \\
\text { Conforme necessidades de } \\
\text { saúde da população na região, } \\
\text { seus mapas de riscos e } \\
\text { vulnerabilidades específicas. } \\
\text { Desenho regional da rede. }\end{array}$ & $\begin{array}{l}\text { Programação dos } \\
\text { componentes da rede } \\
\text { conforme matriz } \\
\text { diagnóstica das } \\
\text { necessidades regionais e } \\
\text { diferentes modalidades } \\
\text { dos componentes da rede. } \\
\text { Desenho regional da rede. }\end{array}$ & $\begin{array}{l}\text { Realização de diagnóstico } \\
\text { e análise da situação de } \\
\text { saúde e elaboração do } \\
\text { desenho regional da } \\
\text { Rede. }\end{array}$ & $\begin{array}{l}\text { Organização e } \\
\text { operacionalização de } \\
\text { linhas de cuidado } \\
\text { específicas, considerando } \\
\text { os agravos de maior } \\
\text { magnitude. }\end{array}$ \\
\hline 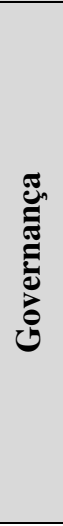 & $\begin{array}{l}\text { Comissão Intergestores } \\
\text { Bipartite (CIB). } \\
\text { Grupo condutor } \\
\text { estadual* } \\
\text { Comissões Intergestores } \\
\text { Regionais (CIR). } \\
\text { Grupo condutor } \\
\text { municipal. } \\
\text { Fórum Rede Cegonha, } \\
\text { como espaço coletivo } \\
\text { plural para participação } \\
\text { cidadã na região. }\end{array}$ & $\begin{array}{l}\text { Comissão Intergestores } \\
\text { Bipartite (CIB). } \\
\text { Grupo condutor estadual* } \\
\text { Comissões Intergestores } \\
\text { Regionais (CIR). } \\
\text { Grupo condutor municipal. } \\
\text { Comitês Gestores Estaduais e } \\
\text { os Comitês Gestores Regionais } \\
\text { do Sistema de Atenção às } \\
\text { Urgências. }\end{array}$ & $\begin{array}{l}\text { Comissão Intergestores } \\
\text { Bipartite (CIB). } \\
\text { Grupo condutor estadual* } \\
\text { Comissões Intergestores } \\
\text { Regionais (CIR). } \\
\text { Grupo condutor } \\
\text { municipal. } \\
\text { Fórum Rede de Atenção } \\
\text { Psicossocial, como } \\
\text { espaço coletivo plural } \\
\text { para participação cidadã } \\
\text { na região. }\end{array}$ & $\begin{array}{l}\text { Comissão Intergestores } \\
\text { Tripartite (CIT). } \\
\text { Comissão Intergestores } \\
\text { Bipartite (CIB), } \\
\text { Grupo condutor } \\
\text { estadual*. } \\
\text { Conselho de Secretários } \\
\text { Municipais de Saúde } \\
\text { (COSEMS). } \\
\text { Comissão Intergestores } \\
\text { Regional (CIR). } \\
\text { Apoio institucional do } \\
\text { Ministério da Saúde. }\end{array}$ & $\begin{array}{l}\text { Comissão Intergestores } \\
\text { Tripartite (CIT). } \\
\text { Comissão Intergestores } \\
\text { Bipartite (CIB). } \\
\text { Comissão Intergestores } \\
\text { Regional (CIR). }\end{array}$ \\
\hline
\end{tabular}




\begin{tabular}{|c|c|c|c|c|c|}
\hline 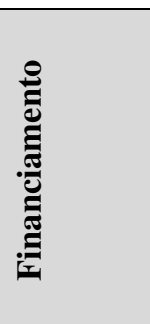 & $\begin{array}{l}\text { Recursos necessários } \\
\text { garantidos pelas três } \\
\text { esferas de governo, } \\
\text { conforme Plano de Ação } \\
\text { Regional. Repasses fundo } \\
\text { a fundo e incentivos } \\
\text { financeiros. }\end{array}$ & $\begin{array}{l}\text { Recursos necessários } \\
\text { garantidos pelas três esferas de } \\
\text { governo, conforme Plano de } \\
\text { Ação Regional. Repasses } \\
\text { fundo a fundo e incentivos } \\
\text { financeiros. }\end{array}$ & $\begin{array}{l}\text { Recursos necessários } \\
\text { garantidos pelas três } \\
\text { esferas de governo, } \\
\text { conforme Plano de Ação } \\
\text { Regional. Repasses fundo } \\
\text { a fundo e incentivos } \\
\text { financeiros. }\end{array}$ & $\begin{array}{l}\text { Recursos necessários } \\
\text { garantidos pelas três } \\
\text { esferas de governo, } \\
\text { conforme Plano de Ação } \\
\text { Regional. Repasses fundo } \\
\text { a fundo e incentivos } \\
\text { financeiros. }\end{array}$ & $\begin{array}{l}\text { Financiamento das linhas } \\
\text { de cuidado priorizadas e } \\
\text { de cada um dos seus } \\
\text { componentes será } \\
\text { regulamentado em atos } \\
\text { normativos específicos a } \\
\text { serem editados pelo } \\
\text { Ministério da Saúde }\end{array}$ \\
\hline 忥 & $\begin{array}{l}\text { Plano de ação regional e } \\
\text { Planos de ação } \\
\text { Municipais, contendo a } \\
\text { programação, as metas, } \\
\text { as atribuições, as } \\
\text { responsabilidades, o } \\
\text { monitoramento, a } \\
\text { avaliação e o aporte de } \\
\text { recursos pelas três esferas } \\
\text { de governo. } \\
\text { Contratualização com os } \\
\text { pontos de atenção à } \\
\text { saúde sob a gestão } \\
\text { federal, estadual e } \\
\text { municipal. }\end{array}$ & $\begin{array}{l}\text { Plano de ação regional e } \\
\text { Planos de ação Municipais, } \\
\text { contendo a programação, as } \\
\text { metas, as atribuições, as } \\
\text { responsabilidades, o } \\
\text { monitoramento, a avaliação e o } \\
\text { aporte de recursos pelas três } \\
\text { esferas de governo. } \\
\text { Contratualização com os } \\
\text { pontos de atenção à saúde sob } \\
\text { a gestão federal, estadual e } \\
\text { municipal. }\end{array}$ & $\begin{array}{l}\text { Plano de ação regional e } \\
\text { Planos de ação } \\
\text { Municipais, contendo a } \\
\text { programação, as metas, as } \\
\text { atribuições, as } \\
\text { responsabilidades, o } \\
\text { monitoramento, a } \\
\text { avaliação e o aporte de } \\
\text { recursos pelas três esferas } \\
\text { de governo. } \\
\text { Contratualização com os } \\
\text { pontos de atenção à saúde } \\
\text { sob a gestão federal, } \\
\text { estadual e municipal. }\end{array}$ & $\begin{array}{l}\text { Plano de ação regional e } \\
\text { Planos de ação } \\
\text { Municipais, contendo a } \\
\text { programação, as metas, as } \\
\text { atribuições, as } \\
\text { responsabilidades, o } \\
\text { monitoramento, a } \\
\text { avaliação e o aporte de } \\
\text { recursos pelas três esferas } \\
\text { de governo. } \\
\text { Contratualização com os } \\
\text { pontos de atenção à saúde } \\
\text { sob a gestão federal, } \\
\text { estadual e municipal. }\end{array}$ & $\begin{array}{l}\text { A Rede será integrada ao } \\
\text { Contrato Organizativo de } \\
\text { Ação Pública em Saúde } \\
\text { (COAP). }\end{array}$ \\
\hline 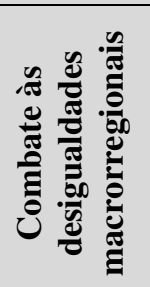 & $\begin{array}{l}\text { Redução da mortalidade } \\
\text { infantil e da desigualdade } \\
\text { na Região Nordeste e na } \\
\text { Amazônia Legal }\end{array}$ & $\begin{array}{l}\text { Incentivo financeiro acrescido } \\
\text { de } 30 \% \text { para custeio das } \\
\text { Unidades Móveis Municipais, } \\
\text { das Centrais de Regulação das } \\
\text { Urgências e das Bases } \\
\text { Descentralizadas situadas na } \\
\text { região da Amazônia Legal. }\end{array}$ & Não mencionado. & Não mencionado. & Não mencionado. \\
\hline
\end{tabular}

Fonte: elaboração própria com base nas portarias do Ministério da Saúde. Rede Cegonha: Portaria 1.459/2011; Portaria no 650/2011. Rede de atenção às urgências e emergências: Portaria no 1.600/2011; Portaria 1.010/2012. Rede de atenção psicossocial: Portaria no 3.088/ 2011. Rede de Atenção à Saúde das Pessoas com Doenças Crônicas: Portaria n ${ }^{\circ}$ 252/2013. *Grupo condutor Estadual formado pela Secretaria Estadual de Saúde e pelo Conselho de Secretarias Municipais de Saúde, com apoio institucional do Ministério da Saúde. 
Em 2011, teve início a experiência de implantação das redes de atenção à saúde, temáticas e prioritárias, considerando a Portaria 4.279 e as diretrizes de regionalização do Decreto 7.508, a partir da execução do Projeto de Investimentos para a Qualificação do Sistema Único de Saúde - QualiSUS-Rede (Portarias ministeriais $n^{\circ} 396 / 2011 ; n^{\circ} 601 / 2011 ; n^{\circ} 1.375 / 2012$ ).

Os objetivos do Projeto são: (i) melhorar a qualidade da atenção e da gestão através do desenvolvimento de tecnologias e do apoio à organização das redes de atenção à saúde; e (ii) melhorar a capacidade de resposta do SUS aos atuais desafios sanitários diante do cenário de crescimento e prevalência das condições crônicas de saúde (BRASIL MS, 2012f). Os recursos obtidos através de empréstimo do Banco Internacional para Reconstrução e Desenvolvimento (BIRD), aprovado em 2009, totalizam US\$ 235 milhões (aproximadamente R \$ 444 milhões), sendo distribuídos conforme os três componentes do projeto: (1) Qualificação do cuidado e organização das RAS, com aporte de US\$ 205 milhões; (2) Intervenções sistêmicas, com aporte de US\$ 26,3 milhões; (3) Gestão, com aporte de US\$ 3,8 milhões (BRASIL MS, 2012f). A execução será realizada em duas fases (2011-2014 e 2015-2020).

O Projeto prevê a elaboração de subprojetos regionais e assinatura de termos de adesão para a implantação de pelo menos duas redes temáticas (Cegonha e Urgência/Emergência) nas regiões selecionadas. Tais regiões não necessariamente coincidem com as regiões de saúde estabelecidas no contexto de implantação do Pacto pela Saúde e, por vezes, são regiões priorizadas no âmbito da Política Nacional de Desenvolvimento Regional (PNDR), a exemplo da Região Integrada de Desenvolvimento Econômico do Distrito Federal e entorno (RIDE-DF).

Foram selecionadas 15 regiões para a implantação dos subprojetos QualiSUSRede, sendo 10 Regiões Metropolitanas e 5 "Regiões Singulares", que expressam a diversidade de situações do país. A seleção incidiu sobre regiões diversas, mas também, com problemas associados ao processo de regionalização e conformação das RAS (BRASIL MS, 2012f).

Os critérios gerais de seleção consideraram: (i) indicadores socioeconômicos: tamanho da população, IDH; (ii) indicadores sanitários: condições de saúde da população, cobertura e qualificação da oferta assistencial, atividades regulatórias dos fluxos assistenciais; (ii) indicadores políticos-institucionais: capacidade de gestão 
pública, recursos próprios aplicados na saúde, existência de instrumentos de planejamento, existência de instituições de ensino superior, sinergia com outros programas e ações ministeriais e capacidade da região para a condução do subprojeto. Os critérios específicos para a seleção de Regiões Metropolitanas (RM) e "Regiões Singulares" (RS) consideraram: (i) RM: locais estratégicos, prioritários e desafiadores para o desenvolvimento do SUS, importância demográfica, contradição entre concentração de riquezas e nível de desigualdades sociais, complexidade e polarização dos recursos e coexistência de diferentes redes de serviços de saúde; (ii) RS: região amazônica com grande presença indígena, fronteira internacional, fronteira interestadual, fronteira de desenvolvimento agropecuário e região do semiárido (Portaria 1375/12).

A seguir estão elencadas as 15 regiões selecionadas pelo Projeto QualiSUSRede e os recursos ${ }^{117}$ destinados para cada uma (Tabelas 1 e 2; Gráficos 1 e 2). Verifica-se que todas as macrorregiões e 17 das 27 Unidades da Federação (UF) foram contempladas pelos subprojetos regionais. Os estados das regiões Sul e Sudeste foram contemplados com $64 \%$ dos recursos totais destinados aos subprojetos metropolitanos das RAS. Já as regiões Norte, Nordeste e Centro-Oeste, historicamente menos favorecidas pela concentração de recursos, infraestruturas, profissionais e equipamentos de saúde, contemplaram a totalidade dos recursos destinados aos subprojetos das RAS nas "regiões singulares".

117 “Com relação à definição dos valores para financiar as intervenções do QualiSUS-Rede nas quinze Regiões, optou-se por estabelecer um critério que considerasse a dimensão/população e, ao mesmo tempo, garantisse um volume mínimo de recursos, sob a perspectiva de assegurar o desenvolvimento de ações que se apresentam como estratégicas à estruturação das Redes de Atenção à Saúde. Assim, o total de recursos destinados ao Componente 1 foi dividido em duas partes iguais, que compõem a parte fixa e a parte variável do total destinado aos projetos desenvolvidos em cada região (denominados Subprojetos). Deste modo, para cada Subprojeto foram destinados, como parte fixa, $1 / 15$ avos sobre $50 \%$ do total de recursos do Componente 1 . Os outros $50 \%$ foram distribuídos de acordo com a população a ser coberta por cada Rede de Atenção à Saúde. Chegou-se então à seguinte fórmula aplicada à distribuição dos recursos:

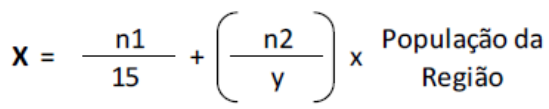

Sendo: X o montante de recursos a ser recebido pela região; n1 (componente fixo) 50\% do total de recursos do Componente 1; n2 (componente variável) os demais 50\% do total de recursos do Componente 1; y o total da população a ser coberta pelo Componente 1." (BRASIL MS, 2012f, p.04). 
Tabela 1 - Regiões Metropolitanas selecionadas para a implantação dos subprojetos QualiSUS-Rede (Brasil, 2012)

\begin{tabular}{|c|c|c|c|c|}
\hline Região Metropolitana & $\mathbf{U F}$ & Macrorregião & $\begin{array}{l}\text { Aporte de recursos por } \\
\text { UF (R\$) }\end{array}$ & $\begin{array}{l}\text { Aporte total de } \\
\text { recursos }(\mathbf{R} \$)\end{array}$ \\
\hline Florianópolis & $\mathrm{SC}$ & Sul & - & $14.146 .999,52$ \\
\hline Grande Teresina & $\mathrm{PI}$ & Nordeste & - & $15.405 .985,72$ \\
\hline Belém & $\mathrm{PA}$ & Norte & - & $18.390 .673,81$ \\
\hline ABC - São Paulo & $\mathrm{SP}$ & Sudeste & - & $20.464 .378,04$ \\
\hline Curitiba & PR & Sul & - & $23.290 .493,03$ \\
\hline Porto Alegre & $\mathrm{RS}$ & Sul & - & $25.037 .727,32$ \\
\hline \multirow{3}{*}{$\begin{array}{l}\text { Ride DF, Ride GO e } \\
\text { Ride MG }\end{array}$} & $\mathrm{DF}$ & Centro-Oeste & $12.455 .723,26$ & \multirow[t]{3}{*}{$25.455 .723,26$} \\
\hline & $\mathrm{GO}$ & Centro-Oeste & $10.800 .000,00$ & \\
\hline & MG & Sudeste & $2.200 .000,00$ & \\
\hline Recife & $\mathrm{PE}$ & Nordeste & - & $26.299 .769,00$ \\
\hline Rio de Janeiro & RJ & Sudeste & - & $30.450 .097,05$ \\
\hline Belo Horizonte & $\mathrm{MG}$ & Sudeste & - & $30.450 .097,05$ \\
\hline & & & Total & 229.391.943,80 \\
\hline
\end{tabular}

Fonte: Portaria $\mathrm{n}^{\mathrm{o}} 1.375 / 2012$

Gráfico 1 - Recursos totais destinados para subprojetos QualiSUS-Rede, nas Regiões Metropolitanas selecionadas, segundo macrorregiões (Brasil, 2012)

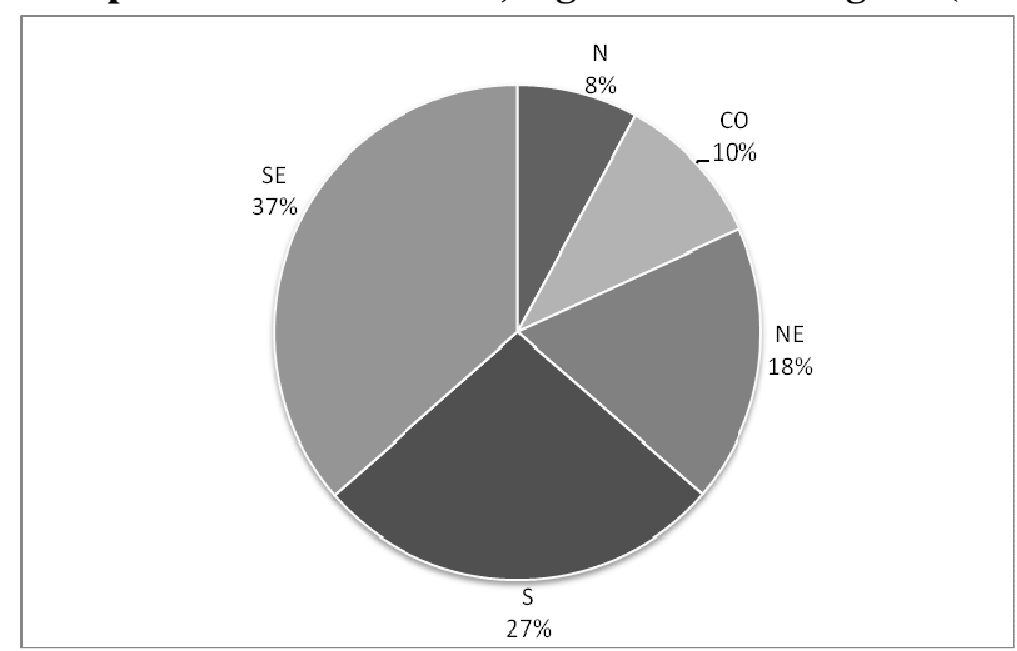

Fonte: elaboração própria com base nas informações da Portaria $n^{\circ}$ 1.375/2012. 
Tabela 2 - Regiões Singulares selecionadas para a implantação dos subprojetos QualiSUS-Rede (Brasil, 2012)

\begin{tabular}{|c|c|c|c|c|}
\hline Região Singular & UF & Macrorregião & $\begin{array}{l}\text { Aporte de } \\
\text { recursos por UF } \\
(\mathbf{R} \$)\end{array}$ & $\begin{array}{l}\text { Aporte total de } \\
\text { recursos (R\$) }\end{array}$ \\
\hline $\begin{array}{l}\text { Região amazônica com destacada } \\
\text { presença indígena: Região do Alto } \\
\text { Solimões }\end{array}$ & $\overline{\mathrm{AM}}$ & Norte & - & $11.373 .396,15$ \\
\hline $\begin{array}{l}\text { Região do Semi-árido: Região do } \\
\text { Cariri }\end{array}$ & $\overline{\mathrm{CE}}$ & Nordeste & - & $12.933 .507,52$ \\
\hline $\begin{array}{l}\text { Região de fronteira internacional: } \\
\text { Região de Ponta Porã }\end{array}$ & $\overline{\mathrm{MS}}$ & Centro-Oeste & - & $13.580 .369,75$ \\
\hline \multirow{2}{*}{$\begin{array}{l}\text { Fronteira de desenvolvimento } \\
\text { agropecuário: Região do } \\
\text { Juazeiro/Petrolina }\end{array}$} & $P E$ & Nordeste & $6.712 .061,09$ & \multirow[t]{2}{*}{$13.723 .168,04$} \\
\hline & $\mathrm{BA}$ & Nordeste & $7.011 .106,95$ & \\
\hline \multirow{3}{*}{$\begin{array}{l}\text { Região de fronteira interestadual: } \\
\text { Região do Bico do Papagaio }\end{array}$} & $\mathrm{TO}$ & Norte & $5.772 .696,09$ & \multirow[t]{3}{*}{$17.318 .088,27$} \\
\hline & $\mathrm{PA}$ & Norte & $5.772 .696,09$ & \\
\hline & MA & Nordeste & $5.772 .696,09$ & \\
\hline & & & Total & 68.928.529,73 \\
\hline
\end{tabular}

Fonte: Portaria ${ }^{\circ} 1.375 / 2012$

\section{Gráfico 2 - Recursos totais destinados para subprojetos QualiSUS-Rede, nas Regiões Singulares selecionadas, segundo macrorregiões (Brasil, 2012)}

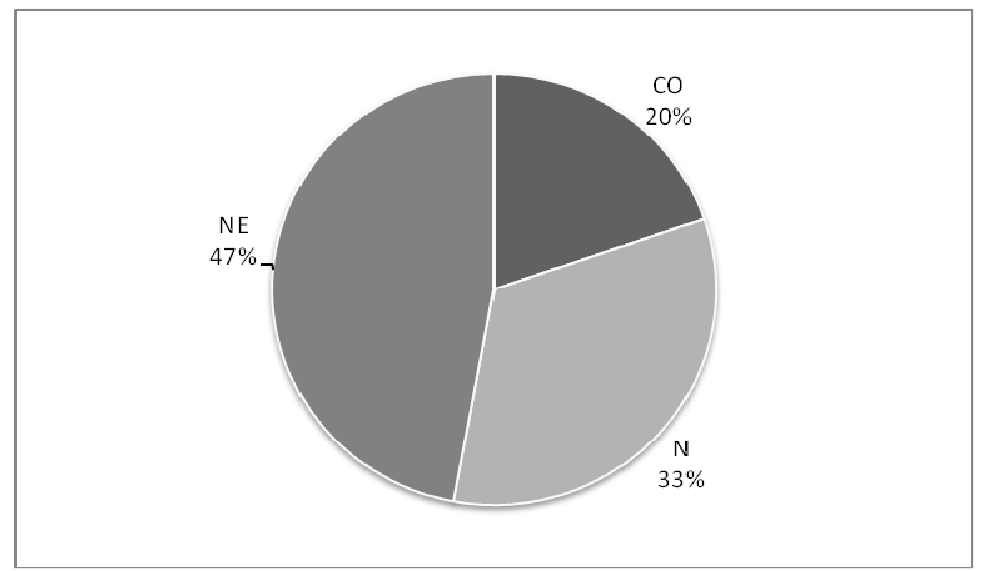

Fonte: elaboração própria com base nas informações da Portaria nº 1.375/2012.

Apesar das desigualdades em relação à destinação dos recursos por tipo de região (metropolitana ou singular), verifica-se que a somatória dos investimentos destinados às 15 regiões selecionadas $(\mathrm{R} \$ 298.320 .473,53)$ resulta numa distribuição mais equitativa do ponto de vista macrorregional (Gráfico 3). Já a repartição dos recursos totais por UF mostra a desigualdade intrarregional no Norte e Nordeste, devido à concentração dos investimentos em alguns poucos estados (Gráfico 4). Dos 
recursos totais destinados à Região Nordeste, $45 \%$ estão alocados em Pernambuco, $21 \%$ no Piauí e $17 \%$ no Ceará. Dos recursos totais destinados à Região Norte, $58 \%$ estão alocados no Pará, 28\% no Amazonas e 14\% em Tocantins. Ao mesmo tempo, os estados das regiões Sul e Sudeste são os que mais receberam recursos para o desenvolvimento dos subprojetos QualiSUS-Rede. Destacam-se entre as UF que receberam acima de R \$ 15 milhões, os estados de Piauí, Pará e Pernambuco. Sete estados, com subprojetos acima de R $\$ 20$ milhões, concentraram 63\% dos recursos totais: SP, PR, PA, RS, RJ, MG e PE.

Gráfico 3 - Recursos totais destinados para subprojetos QualiSUS-Rede, nas 15 regiões selecionadas, segundo macrorregiões (Brasil, 2012)

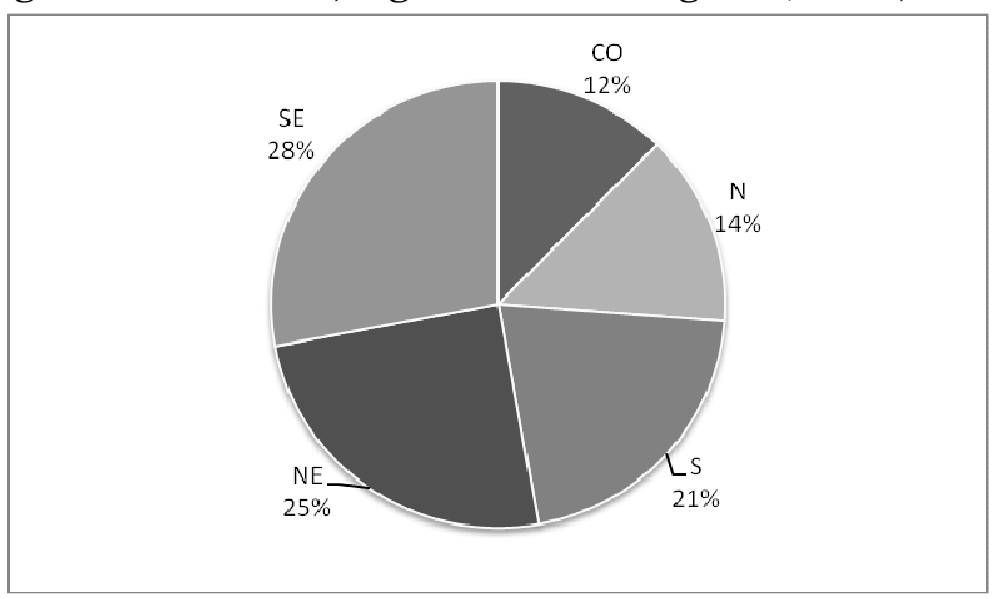

Fonte: elaboração própria com base nas informações da Portaria n 1.375/2012.

Gráfico 4 - Recursos totais destinados para subprojetos QualiSUS-Rede, nas 15 regiões selecionadas, segundo UF (2012)

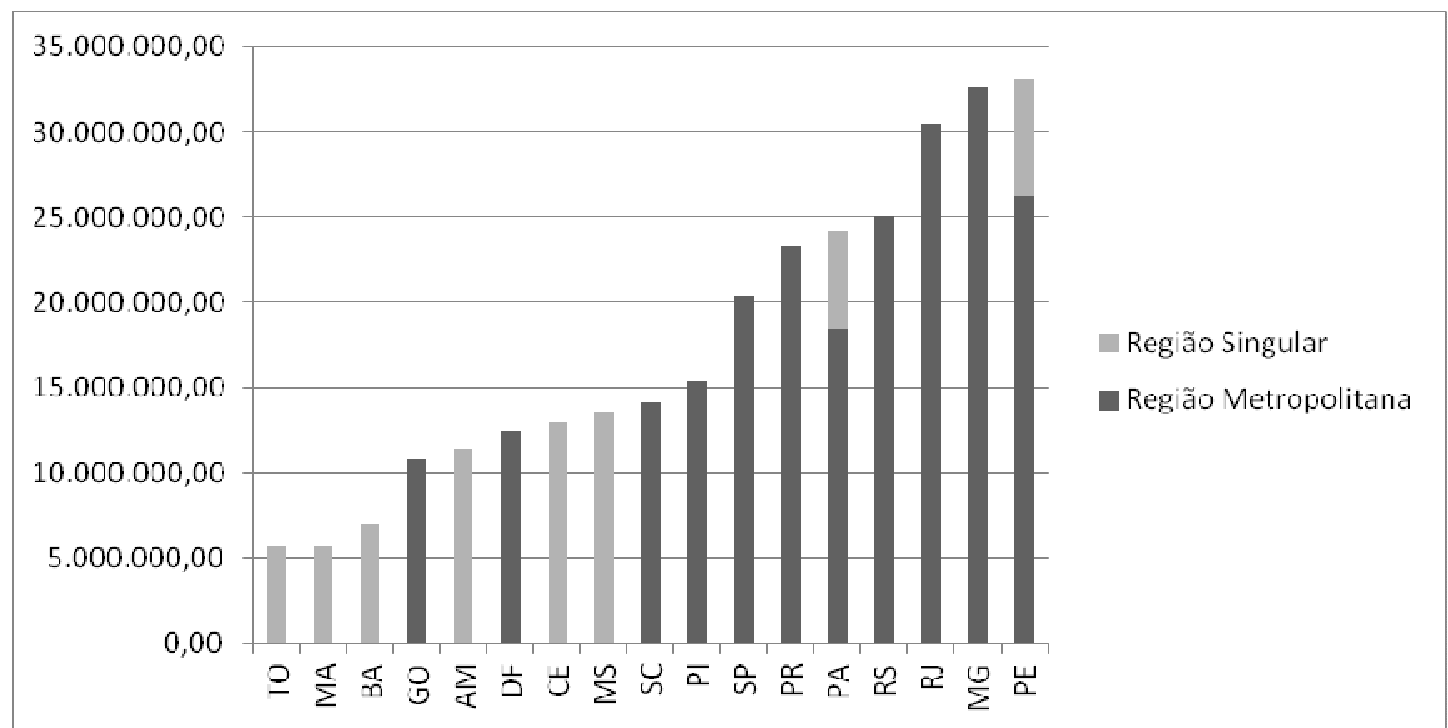

Fonte: elaboração própria com base nas informações da Portaria nº 1.375/2012. 
O Projeto QualiSUS-Rede é uma experiência interessante do ponto de vista da regionalização do SUS e da conformação das redes de atenção à saúde, por três motivos principais. Primeiro, porque relaciona as diretrizes das RAS (Portaria 4279) com as novas diretrizes da regionalização (Decreto 7508). Segundo, porque seleciona regiões a partir de outras perspectivas que não apenas a assistencial, isto é, considerando a diversidade de situações socioeconômicas e socioespaciais existentes no país e as regiões vinculadas e/ou definidas pelas políticas nacionais de desenvolvimento regional. Terceiro, porque apoia a elaboração de pesquisas ${ }^{118}$ científicas voltadas exclusivamente para as 15 regiões selecionadas, estreitando a articulação nacional entre as políticas de assistência à saúde, de planejamento e gestão do SUS e de ciência, tecnologia e inovação em saúde.

O Quadro 6, a seguir, elenca os principais eventos relacionados à institucionalização das redes de saúde na política nacional de saúde, evidenciando um aumento crescente na densidade normativa relacionada a essa estratégia, sobretudo, a partir de 2007.

\section{Quadro 6 - Principais eventos relacionados à institucionalização das redes de atenção à saúde na política nacional de saúde $(1990$ - 2012)}

\begin{tabular}{|l|l|}
\hline Ano & Eventos \\
\hline 1990 & $\begin{array}{l}\text { Lei Orgânica da Saúde 8.080 traz entres as diretrizes de organização do SUS a construção de } \\
\text { redes assistenciais regionalizadas hierarquizadas }\end{array}$ \\
\hline 2001 & $\begin{array}{l}\text { Norma Operacional de Assistência à Saúde (Noas) institui o processo de regionalização do } \\
\text { SUS } \\
\text { Portaria 1020: estabeleceu os objetivos gerais da Programação Pactuada e Integrada - PPI da } \\
\text { assistência, visando à construção das redes regionalizadas e hierarquizadas. }\end{array}$ \\
\hline 2002 & $\begin{array}{l}\text { Portaria 702: Redes Estaduais de Assistência à Saúde do Idoso } \\
\text { Portaria 866: Redes Estaduais de Assistência em Oftalmologia } \\
\text { Portaria 640: Redes Estaduais de Assistência Cardiovascular }\end{array}$ \\
\hline 2003 & $\begin{array}{l}\text { Portaria 1864: orienta a implantação do Serviço de Atendimento Móvel às Urgências (Samu), } \\
\text { em municípios e regiões de todo o território brasileiro, no âmbito do SUS. }\end{array}$ \\
\hline 2004 & $\begin{array}{l}\text { Portaria 587: Redes Estaduais / Municipais de Atenção à Hanseníase } \\
\text { Portaria 1169: Rede Estadual e/ou Regional de Atenção em Alta Complexidade } \\
\text { Cardiovascular } \\
\text { Portaria 211: Redes Estaduais de Assistência em Nefrologia na alta complexidade } \\
\text { Portaria 587: Redes Estaduais de Atenção à Saúde Auditiva }\end{array}$ \\
\hline
\end{tabular}

${ }^{118}$ Os estudos apoiados pelo Ministério da Saúde, no âmbito do Projeto QualiSUS-Rede, abrangem os seguintes temas: gestão de custos em redes de atenção à saúde no SUS; modelo de financiamento tripartite do sistema; experiências da gestão do cuidado das condições crônicas em municípios brasileiros; modelos de governança e contratualização instituídos no Brasil; planejamento regional em saúde (Decit/MS). 


\begin{tabular}{|c|c|}
\hline 2005 & $\begin{array}{l}\text { Portaria 388: Redes estaduais, municipais e do Distrito Federal de Atenção em Reprodução } \\
\text { Humana Assistida. } \\
\text { Portaria 391: Redes Estaduais de Assistência ao Paciente Neurológico na Alta Complexidade }\end{array}$ \\
\hline 2006 & $\begin{array}{l}\text { Pacto pela Saúde define novas diretrizes à regionalização do SUS } \\
\text { Negociações do Ministério da Saúde com o Banco Mundial para contratação do Projeto } \\
\text { QualiSUS-Rede (Brasil SF, 2009). } \\
\text { Portaria 31: Grupo Técnico de Assessoramento para o Planejamento, Avaliação e Aprovação } \\
\text { da Rede de Atenção Oncológica dos Estados. } \\
\text { Portaria 432: Redes Estaduais de Assistência em Nefrologia na alta complexidade } \\
\text { Portaria 3125: Institui o Programa QualiSUS para a estruturação da Rede de Atenção às } \\
\text { Urgências. }\end{array}$ \\
\hline 2007 & Criação da Diretoria de Articulação de Redes de Atenção à Saúde (DARAS/SAS/MS) \\
\hline 2008 & $\begin{array}{l}\text { Elaboração do Documento Base pelo Ministério da Saúde: "Redes regionalizadas de Atenção } \\
\text { à Saúde: contexto, premissas, diretrizes gerais, agenda tripartite para discussão e proposta de } \\
\text { metodologia para apoio à implementação" (Brasil MS, 2008d). } \\
\text { Portaria 2922: Implementação do componente de "Organização de redes loco-regionais de } \\
\text { atenção integral às urgências" da Política Nacional de Atenção às Urgências } \\
\text { Portaria 2928: Grupo de Trabalho para formulação de agenda relativa à estratégia de Redes } \\
\text { Regionalizadas de Atenção à Saúde } \\
\text { Portaria 2970: Regionalização da Rede Nacional Serviço de Atendimento Móvel de Urgência } \\
\text { (Samu) } \\
\text { Portaria 2971: Novos critérios técnicos e financeiros da Rede Samu } \\
\text { Portaria 2972: Continuidade do Programa de Qualificação da Atenção Hospitalar de Urgência } \\
\text { no Sistema Único de Saúde - Programa QualiSUS, priorizando a organização e a qualificação } \\
\text { de redes loco-regionais de atenção integral às urgências. }\end{array}$ \\
\hline 2009 & $\begin{array}{l}\text { Contratação do Projeto QualiSUS-Rede, pelo Ministério da Saúde com o Banco Mundial } \\
\text { (Brasil SF, 2009). } \\
\text { Portaria 1020: Estabelece diretrizes para a implantação do componente pré-hospitalar fixo - } \\
\text { UPA e SE - visando a organização de redes loco-regionais de atenção integral às urgências. }\end{array}$ \\
\hline 2010 & $\begin{array}{l}\text { Portaria 1857: Redes Estaduais de Serviços de Reabilitação para Pessoas com Deficiência } \\
\text { Portaria 577: Institui o projeto QualiSUS-Rede. } \\
\text { Portaria 4279: estabelece as diretrizes das Redes de Atenção à Saúde }\end{array}$ \\
\hline 2011 & $\begin{array}{l}\text { Transformação da Diretoria de Articulação de Redes de Atenção à Saúde em Departamento de } \\
\text { Articulação de Redes de Atenção à Saúde (DARAS/SAS/MS) } \\
\text { Portaria 451: Grupo Técnico de Trabalho com a finalidade de pactuar normas, parâmetros, } \\
\text { diretrizes técnicas e clínicas, à luz da Política Nacional de Implantação das Redes de Atenção } \\
\text { à Saúde. } \\
\text { Portaria 1473: Institui os Comitês Gestores, Grupos Executivos, Grupos Transversais e os } \\
\text { Comitês de Mobilização Social e de Especialistas dos compromissos prioritários de governo } \\
\text { organizados por meio de Redes Temáticas de Atenção à Saúde. } \\
\text { Decreto no } 7.508 \text { define novas diretrizes de regionalização do SUS } \\
\text { Portarias 1459, 2351, 650: Rede Cegonha } \\
\text { Portarias 1600, 1010: Rede de atenção às urgências e emergências } \\
\text { Portaria 3088: Rede de atenção psicossocial } \\
\text { Portaria 601: dispõe sobre a organização e as competências da Unidade de Gestão do Projeto } \\
\text { (UGP) do Projeto QualiSUS-Rede e define o arranjo de gestão para execução de subprojetos. }\end{array}$ \\
\hline
\end{tabular}




\begin{tabular}{|c|c|}
\hline 2012 & $\begin{array}{l}\text { Assinatura dos primeiros Contratos Organizativos da Ação Pública em Saúde (Coap) nas } \\
\text { regiões de saúde (estados do Ceará e Mato Grosso do Sul). } \\
\text { Política Nacional de Atenção Básica (Brasil MS, 2012e) traz novo modelo de atenção } \\
\text { efetivando a atenção primária em saúde como eixo estruturante das redes de atenção à saúde. } \\
\text { Portaria 253: Grupo Técnico de Trabalho para propor diretrizes e estratégias para a } \\
\text { qualificação da Assistência Farmacêutica no Sistema Único de Saúde, com foco no serviço } \\
\text { farmacêutico nas redes assistências prioritárias do Ministério da Saúde. } \\
\text { Portaria 433: habilitação em Média e Alta Complexidade (Cardiologia, Oftalmologia, } \\
\text { Nefrologia e Neurocirurgia) conforme critérios técnicos das áreas e o contexto das redes de } \\
\text { atenção à saúde. } \\
\text { Portaria 1375: Define as regiões selecionadas para participação e implementação das ações } \\
\text { dos subprojetos do Projeto QualiSUS-Rede. } \\
\text { Portaria 2809: Estabelece a organização dos Cuidados Prolongados para retaguarda à Rede de } \\
\text { Atenção às Urgências e Emergências (RUE) e às demais Redes Temáticas de Atenção à Saúde } \\
\text { no âmbito do Sistema Único de Saúde (SUS). } \\
\text { Portarias aprovam Planos de Ação Estaduais de implantação das redes prioritárias. } \\
\text { Portaria 793: Rede de Cuidado à Pessoa com Deficiência }\end{array}$ \\
\hline 2013 & ção à Saúde das \\
\hline
\end{tabular}

Elaboração própria, com base em consulta realizada sobre portarias e normas federais referentes às redes assistenciais de saúde. Fonte:

http://portal2.saude.gov.br/saudelegis/leg_norma_pesq_consulta.cfm (acesso em janeiro de 2013).

A política nacional de saúde demorou vinte anos, desde a criação do SUS, para desenvolver um conceito de rede de saúde e suas diretrizes operacionais. Mesmo com a publicação da primeira diretriz de regionalização, a Noas, o conceito de rede - fundamental para se pensar a estruturação de regiões -, não foi definido. A primeira fase da regionalização do SUS tinha como um dos principais objetivos reverter o quadro de atomização da gestão e planejamento dos serviços no nível municipal, através da estruturação de redes funcionais assistenciais. Um dos maiores avanços nesse sentido foi o incentivo para a regulação assistencial pelos estados e as portarias federais voltadas para a conformação de redes estaduais de assistência especializadas em determinadas doenças, perfil social ou condições de vida. Entretanto, considerando-se a complexidade de gestão tripartite do SUS e a diversidade de instituições públicas e privadas que participam da oferta assistencial, naquele momento, a definição de rede de saúde seria um passo importante a ser dado pela política nacional, para além das definições constitucionais.

O fraco papel desempenhado pelo Estado no planejamento das redes e regiões de saúde prejudicou o fortalecimento da capacidade pública de induzir a divisão territorial do trabalho em saúde (distribuição e especialização dos serviços no território e estruturação de redes e regiões de saúde), nas escalas estadual e nacional, com vistas à universalização e diminuição das desigualdades socioespaciais em 
saúde. A implantação da regionalização proposta pela Noas e da Programação Pactuada Integrada (PPI) contribuiu para o início da estruturação de redes de saúde, porém, com pouco impacto em termos operacionais e estruturais (integração das ações e serviços em redes).

Entre 2003 e 2006, houve uma transição conceitual na política nacional de saúde através da introdução do termo redes de atenção à saúde. A diversidade de nomenclaturas para redes de saúde utilizadas no Pacto pela Saúde mostrou a preocupação com a integração das ações e serviços do SUS, sem que fosse definido um conceito de rede específico. O foco principal do documento não foi a conformação de redes, mas, sim, a elaboração de um novo conceito de região de saúde, através do qual se almejava alcançar maior cooperação e articulação entre as esferas de governo para avançar na gestão regional do SUS.

Apenas em 2010, a Portaria 4279 definiu os conceitos e diretrizes operacionais das redes de atenção à saúde no SUS, que ganharam institucionalidade na política nacional a partir dos novos conceitos e instrumentos técnicos, científicos e normativos.

Além da grande influência exercida pelas instituições internacionais (OMS, Opas, Banco Mundial e Bird) para a introdução do conceito de redes de atenção à saúde no Brasil, a retomada do papel do Estado no planejamento e a proposição de um projeto de desenvolvimento também foram fatores cruciais para o salto institucional da estratégia de conformação de redes e regiões de saúde. Por um lado, aumentou a capacidade pública de elaboração dos instrumentos de planejamento, incluindo o planejamento regional, associado ao fortalecimento das relações federativas, cooperativas e coordenadas. Por outro lado, a elaboração de uma nova estratégia de desenvolvimento regional pelo Estado brasileiro fez com que as redes técnicas e políticas ganhassem uma nova dimensão e função, além daquela de garantir competitividade para o mercado, sendo valorizadas enquanto redes públicas e intergovernamentais, mobilizadas para a efetivação das políticas de desenvolvimento, incluindo a saúde.

As redes de atenção à saúde tornaram-se instrumentos-chave da política nacional. E apesar da aproximação técnica e conceitual entre as diretrizes da regionalização e das redes de atenção à saúde, o Ministério da Saúde tem conduzido 
esse novo processo por meio de incentivos financeiros mais atrelados às redes temáticas e prioritárias e menos ao planejamento regional em si.

As redes de atenção à saúde podem fortalecer o processo de regionalização do SUS, pois são fundamentais para a indução da divisão territorial do trabalho em saúde e da solidariedade entre os lugares e regiões do país para garantir a integralidade do cuidado. Contudo, parece haver pouca integração entre o planejamento regional e o planejamento e financiamento das RAS. Na verdade, parece haver uma sobrevalorização das redes em relação às regiões de saúde.

A regionalização introduziu um novo espaço político de negociação e cooperação intergovernamental (a CIR), mas, através das redes de atenção à saúde foram introduzidos novos conceitos, como o de governança e linhas de cuidado, com grande influência sobre as diretrizes atuais de regionalização do SUS. Além disso, a política das redes temáticas e prioritárias detalha o financiamento tripartite dos seus componentes, os serviços específicos mínimos, os equipamentos necessários, a integração com outras ações e serviços e a matriz diagnóstica (indicadores).

O foco nas redes segue a lógica da racionalidade administrativa do Ministério da Saúde de distribuição de recursos financeiros para os entes subnacionais, aprimorando as relações e os mecanismos de transferência e buscando maior consonância entre as diretrizes da política nacional e as demandas dos níveis subnacionais (MENICUCCI, 2011). Os investimentos nas redes também se apresentam como uma tentativa de aumentar a capacidade de direcionamento dos recursos federais para ampliar a rede de serviços e diminuir as desigualdades regionais. Entretanto, os investimentos federais nas RAS são insuficientes e fragmentados, limitando a orientação estratégia da política nacional sobre a evolução e a configuração das redes e regiões de saúde (GADELHA et al., 2011).

Existe outro fator limitante para o fortalecimento da regionalização através da implantação das RAS: os instrumentos de planejamento e gestão da região contratualizada $^{119}$ não expressam a diversidade dos arranjos entre Mercado e Estado $^{120}$ no sistema de saúde brasileiro, tanto do ponto de vista assistencial, quanto

\footnotetext{
${ }^{119}$ Definida no Capítulo 1 deste trabalho.

${ }^{120}$ Estado e Mercado disputam e/ou cooperam, no Brasil, o comando sobre a organização e o funcionamento da assistência à saúde desde o início do estabelecimento de uma política nacional de saúde (VIANA \& SILVA, 2012).
} 
produtivo industrial. Entretanto, os diferentes arranjos públicos e privados na estruturação do sistema de saúde em termos de oferta de ações, serviços e tecnologias, indicam a existência de conflitos entre a estratégia de conformação das RAS e de gestão regional do SUS.

As Comissões Intergestores Regionais são espaços pouco afeitos à participação política de outros atores, que não os estatais (secretários e técnicos das secretarias municipais e estaduais) (VIANA \& LIMA, 2011). Já as redes de atenção à saúde contemplam uma ampla diversidade de atores, instituições e interesses. Os agentes do mercado, para implantar suas estratégias de aumento de lucro, exercem influência diretamente sobre os gestores do SUS e não nos fóruns de negociação e participação na saúde (CORTES, 2009; SILVA \& VIANA, 2011). As grandes empresas de tecnologia do setor médico-hospitalar, por exemplo, atuam junto aos médicos e grandes prestadores para influenciar o processo de incorporação tecnológica na saúde, conformando redes de agentes e instituições públicos e privados que fazem a mediação entre a produção científica e tecnológica na saúde e a política assistencial (VIANA \& SILVA, 2010), mas essa estratégia do mercado não é abordada na discussão do planejamento regional do SUS.

Por um lado, a regionalização do SUS representa a retomada do papel do Estado no planejamento e favorece a estruturação das RAS. Por outro lado, as RAS atualizam os arranjos entre Estado e Mercado no sistema de saúde, podendo limitar o projeto de universalização da saúde no Brasil.

Em síntese, desde o início da implementação do SUS, a conformação das redes de saúde seguiu diversas lógicas de integração entre os serviços do SUS, pautadas tanto pela espontaneidade de acesso dos pacientes aos equipamentos de saúde, quanto pela tentativa de regulação desses fluxos assistenciais através de estratégias e instrumentos específicos de planejamento (PPI, centrais e complexos reguladores, entre outros).

O modelo de estruturação de redes e regiões de saúde proposto pela Noas não dialogou com a dimensão territorial do projeto de universalização da saúde. O Pacto pela Saúde apostou na flexibilização da conformação de redes e regiões, apesar de manter alguns dos instrumentos de planejamento e gestão da Noas, para tentar buscar uma adequação mais efetiva entre as diretrizes nacionais e as realidades locais. 
Mas somente a partir de 2010, com a publicação da Portaria 4.279, do Decreto 7.508/11 e das portarias referentes às redes temáticas de atenção à saúde é que se inicia um processo mais efetivo de estruturação de redes assistenciais regionalizadas, amparada por definições e instrumentos específicos.

A implantação das redes de atenção à saúde tende a reforçar a importância das regiões de saúde como lócus para indução de mudanças técnicas e políticas no sistema de saúde e o papel das Comissões Intergestoras Regionais (CIRs) para promover a cooperação intergovernamental em prol da integração sistêmica das ações e serviços do SUS. A elaboração de projetos regionais para a implantação das redes temáticas é um exemplo de reforço da institucionalidade das regiões de saúde no âmbito da política nacional.

Contudo, os esforços técnicos, políticos, financeiros e normativos voltados para a implantação das redes temáticas de atenção à saúde também tendem a fragmentar a estratégia regional de organização do SUS.

Quando os equipamentos e ações do SUS passam a integrar redes de atenção à saúde, são coordenados de forma hierarquizada (especialidades dos serviços e complexidade tecnológica) e solidária (interdependência através da regulação dos fluxos assistenciais, materiais e informacionais, segundo as linhas de cuidado da rede e a hierarquia dos serviços). A estruturação das redes assistenciais torna ainda mais complexa a ideia de regionalização do sistema, pois as redes ultrapassam os limites territoriais (municipais e estaduais) e os desenhos das regiões de saúde, combinando a todo momento conteúdos externos e internos territórios e regiões.

As redes temáticas, cada qual especializada em determinadas linhas de cuidado, possuem diferentes lógicas de integração e hierarquização entre serviços e tecnologias assistenciais. Cada rede temática induz uma determinada solidariedade organizacional entre lugares que abrigam os serviços conectados à rede, organizando uma divisão territorial do trabalho em saúde específica. Além disso, a extensão das redes temáticas tende a ultrapassar os limites das regiões de saúde, dado que a capacidade de resposta do sistema às necessidades em saúde, através da integralidade do acesso às ações e serviços, depende de uma articulação lugares mais e menos distantes entre si, mais e menos especializados em determinadas atividades e tecnologias, pois os equipamentos do SUS se distribuem de maneira desigual e 
concentrada no território. O município de São Paulo, por exemplo, exerce grande poder de concentração dos investimentos em serviços e tecnologias assistenciais, servindo, no limite, como ponto de referência para a grande maioria dos municípios brasileiros. O atendimento às necessidades de saúde requer várias escalas espaciais e temporais de integração e articulação dos serviços e ações assistenciais em rede. Para cada rede, uma dada divisão territorial do trabalho e uma lógica regional de organização e integração dos serviços.

Nesse sentido, o desenho da região de saúde dificilmente corresponderá à lógica de uma rede temática específica. Cada região de saúde abrigará alguns nós (serviços) das redes, organizando uma parte dos fluxos assistenciais e da integração entre as ações e serviços. Estes, por sua vez, poderão estar conectados a mais de uma rede temática, conforme sua especialização e hierarquia no atendimento às necessidades de saúde da população. A atenção básica e os hospitais, que abrangem um leque maior de especialidades e atendimentos, serão referência para mais de uma rede temática numa mesma região de saúde.

Com os esforços cada vez mais voltados para a implantação das redes de atenção, caberia questionar o qual será o papel das Comissões Intergestores Regionais nesse processo? Como elas organizam pedaços dessas redes e possibilitam a realização de conexões geográficas com outras regiões de saúde, para o cumprimento da universalidade e integralidade do atendimento à saúde?

Nos próximos anos, será importante aprofundar as análises sobre a relação entre regiões de saúde e redes de atenção à saúde, considerando as distintas lógicas de funcionamento do SUS nos lugares e as novas diretrizes, instrumentos e definições para a universalização da saúde no Brasil. 


\section{Capítulo 4. Experiência recente de regionalização do Sistema Único de Saúde nos estados brasileiros (2007-2010)}

Nos estados, a regionalização se revela uma estratégia extremamente complexa de planejamento e gestão do Sistema Único de Saúde. Primeiro, porque depende da negociação entre diferentes níveis de governo, cada qual com suas autonomias, responsabilidades e trajetórias institucionais. Segundo, porque entes federados que são iguais perante as leis, são diversos e desiguais quanto aos usos do território e dinâmicas econômicas que abrigam e isso tem consequências para a conformação do sistema e das políticas de saúde locais. Terceiro, porque a organização regional do sistema e de suas redes assistenciais não se restringe aos acordos intergovernamentais, sendo influenciada pela interação entre diferentes agentes e instituições públicas e privadas que participam do funcionamento do sistema de saúde.

Nesse sentido, questiona-se: é possível verificar mudanças induzidas pelas diretrizes nacionais no processo de regionalização do SUS nos estados, a partir da segunda metade da década de 2000? Em que sentido evoluiu a regionalização nos estados e como compreender os condicionantes e as especificidades desse processo?

Para responder a essas questões, é necessário avaliar os diferentes estágios e as características do processo de regionalização nos estados brasileiros, considerando-se que: (i) a conformação das regiões depende de uma base técnica e política para ser efetivada, fundamentalmente de um acordo intergovernamental em torno de usos do território compartilhados (demandas da população, serviços e ações de saúde, redes e fluxos assistenciais); e (ii) nos estados, as diversidades e desigualdades regionais se expressam tanto pelas condições de vida e saúde da população, de acesso aos serviços assistenciais e de funcionamento do sistema de saúde, como, também, pelas condições político-institucionais, técnicas e financeiras dos governos para a execução das políticas e diretrizes de planejamento regional do SUS. 
Neste capítulo foram utilizados os resultados do estudo coordenado por Viana \& Lima (2011), que analisou os diferentes estágios e condicionantes do processo de regionalização nos estados brasileiros, entre 2007 e 2010, após a publicação do Pacto pela Saúde.

Os principais objetivos do estudo foram: analisar os processos de regionalização em saúde nos estados brasileiros, identificando cada contexto e seus condicionantes institucionais e políticos, além dos impactos e inovações introduzidos nos sistemas de saúde; avaliar a dinâmica de funcionamento das Comissões Intergestores Bipartites (CIB) e suas inter-relações com os processos de regionalização nos estados.

A regionalização foi analisada sob o ponto de vista do processo político que envolve mudanças na distribuição de poder e o estabelecimento de um sistema de inter-relações entre diferentes atores sociais (governos, organizações públicas e privadas, cidadãos) atuantes no território. A regionalização inclui, ainda, a formulação e implementação de estratégias e instrumentos de planejamento, integração, gestão, regulação e financiamento de uma rede de ações e serviços no território.

Em suma, a regionalização implica numa mudança no exercício de poder (redistribuição de poder) no interior da política de saúde o que se traduz na introdução de novos atores, objeto, normas e processos, governado/liderado por diferentes orientações/ideologias. Essa abordagem assume que a regionalização é influenciada pelas características específicas da sua implementação na esfera estadual e, ainda, pelos rumos ou direção que se deseja imprimir ao processo. Os fatores que condicionam a regionalização nos estados também permitem explicar seus resultados, bem como seu avançado ou incipiente estágio de consecução.

O estudo se apoiou no referencial de análise das políticas públicas, que tem como objeto o curso da ação proposta por um ator ou grupo de atores, seus determinantes, suas finalidades, seus processos e suas consequências (VIANA \& BAPTISTA, 2008). Foram valorizados os contextos políticos, econômicos e sociais específicos dos estados brasileiros, bem como questões de ordem macroestruturais (HAM \& HILL, 1993) como aquela referente à inserção da regionalização na política nacional. $\mathrm{O}$ estudo incorporou ainda as contribuições do neoinstitucionalismo, 
particularmente a vertente histórica (HALL \& TAYLOR, 2003), tendo em vista que o foco da investigação esteve direcionado aos condicionantes histórico-institucionais da regionalização da saúde nos estados, dando destaque às regras de atuação dos governos, escolhas políticas, atores mobilizados e aspectos políticos nas articulações intergovernamentais. A noção de dependência de trajetória (path-dependence e increasing-returns) que está relacionada à ideia de que acontecimentos do passado podem dar vazão a uma cadeia de determinações que influenciam as decisões políticas no presente (THELEN \& STEINMO, 1992; PIERSON, 2004), também foi utilizada para analisar o processo de regionalização como um resultado de uma sequencia inteira de decisões tomadas por agentes e suas respectivas consequências e não apenas das condições conjunturais. Isso não se traduz simplesmente pelo fato de que "a história e o passado contam", mas sim que, no âmbito das políticas públicas, quando se adota um caminho, os custos políticos e econômicos de mudá-lo são, em geral, muito altos (PIERSON, 2004).

Três dimensões desdobradas em categorias sintetizam o referencial analítico dos condicionantes da regionalização nos estados (Quadro 7): contexto (históricoestrutural, político-institucional e conjuntural), direcionalidade (ideologia, objeto, atores, estratégias e instrumentos), características da regionalização (institucionalidade, governança). Foram também verificados os impactos institucionais resultantes desse processo.

Compreende-se que a regionalização pode ser favorecida ou dificultada por um contexto histórico-estrutural (história da conformação do estado e de suas regiões, dinâmicas socioeconômicas e territorial dos estados), político-institucional (trajetória da política de saúde e da regionalização, modo de funcionamento das instituições e papel desempenhado pelas organizações envolvidas) e conjuntural (prioridade da regionalização na agenda dos governos, situação político-econômica do estado e perfil dos dirigentes da saúde) que varia entre os estados.

A direcionalidade da regionalização expressa a capacidade dos dirigentes de orientarem o processo (DENIS J-L et al., 2008) definindo os atores, o objeto, as estratégias e os instrumentos envolvidos na implementação da regionalização no nível estadual. 
A institucionalidade da regionalização no plano estadual foi caracterizada pela existência de estratégias, recursos, incentivos, normas e construções cognitivas que integram o processo regulatório dessa política (SCOTT, 1995). A noção de institucionalidade relaciona-se ainda com a trajetória da regionalização e com os elementos e critérios considerados na definição do desenho das regiões de saúde no estado. Em sua análise pesam o histórico da regionalização; a robustez e conteúdo do desenho da regionalização, e ainda pela capacidade de introdução de estratégias de planejamento e regulação, voltada para coordenação de ações e serviços e intervenções sanitárias em âmbito regional. Além de níveis mais altos de efetividade, propiciam ainda a definição e implantação de mecanismos de financiamento/investimentos específicos. Não se pode falar de institucionalidade sem considerar o peso específico do papel da Secretaria de Estado de Saúde na condução do processo, o que inclui a maturidade técnica e política de suas regionais e o peso da regionalização na agenda oficial. Assim, segundo o desenvolvimento conjunto de normas, estratégias, projetos e incentivos regionais foram considerados três estágios de institucionalização: incipiente, parcial e avançada.

Finalmente, a governança da regionalização foi determinada pela estabilidade do quadro institucional, pela gama de atores participantes, pelo tipo de relações intergovernamentais e entre as organizações responsáveis pela condução do processo (DEFARGES, 2008), sendo possível estabelecer uma direção para a consecução de objetivos e metas acordados entre eles. Faz-se necessário esclarecer que o uso diferenciado das acepções governo e governança se apoiou na noção de que os campos de um e outro são diversos: assuntos públicos (governo) e coletivos (governança), em que se contrastam processos decisórios de ordem hierárquica (governo) com a negociação (governança) e cuja tendência é a diversidade (governança) frente à unidade (governo). A governança amplia o conceito de governo ao incluir dispositivos informais e não governamentais pelos quais pode ser guiada a ação coletiva. Deste modo pode ser entendida como um sistema de regras que se apoia em um jogo de relações envolvendo atores públicos e privados, nos quais indivíduos e instituições expressam seus próprios interesses e esses podem ser organizados segundo alguns objetivos comuns (negociados), resultando em elos e redes entre esses mesmos atores e instituições. 
Sua categorização na saúde - e mais especificamente no processo de regionalização - pode ser defendida sobre as próprias características dos sistemas de saúde atuais, no qual a fronteira do público e do privado é cada vez mais tênue. Além disso, do ponto de vista territorial, se conformam complexos e redes específicas de saúde com dinâmicas próprias, muitas vezes pouco ou quase nada subordinadas às regras nacionais ou gerais, tendo em vista o grau de autonomia em que operam. É o caso, por exemplo, das inúmeras construções de instâncias não oficiais de negociação e definições de objetivos comuns por um mix público-privado regional, muitas vezes não identificados e incluídos nos mecanismos públicos de planejamento. Outro aspecto importante é a ideia de que o interesse geral não está mais inscrito de forma cabal na ação pública, mas necessita de um processo permanente de construção multiforme e aberta. Em suma, esta categoria permite desvelar o processo de negociação em saúde, isto é, a ação coletiva de um poderoso mix público e privado disperso territorialmente, heterogêneo do ponto de vista dos atores, com graus variados de recursos, em diferentes modalidades e padrões de governança. Integram essa dimensão a diversidade e peso dos atores envolvidos; natureza e tipos de relacionamento entre eles; além do estabelecimento de mecanismos de coordenação. A importância da Comissão Intergestores Bipartite (CIB) e o seu papel estratégico no processo de regionalização foi um importante elemento auxiliar no estabelecimento de tipos específicos de governança, direcionando o olhar para os padrões de relacionamento entre SES e municípios nos espaços regionais. $\mathrm{Na}$ análise do conjunto dos estados visitados foram identificados cinco padrões de governança para o processo de regionalização: coordenada/cooperativa; cooperativa; coordenada/conflitiva; conflitiva; e indefinida.

$\mathrm{Na}$ governança coordenada/cooperativa se estabelece uma direção para $\mathrm{o}$ processo de regionalização com definição de metas e objetivos específicos e há uma relação de cooperação entre os atores (principalmente os governamentais). Embora na mesma direção, a governança cooperativa ressente-se de uma coordenação explícita, da fragilidade dos mecanismos de coordenação entre os atores, o que naturalmente confere um papel mais débil e formalista à CIB. A governança coordenada /conflitiva expõe um caso onde apesar de existir um comando claro no processo, há muitos conflitos entre os atores e são fracos os mecanismos de 
concertação. Por fim, o tipo conflitivo pressupõe um universo técnico-político conflituoso e com baixa coordenação.

Os impactos e inovações institucionais provocados pelo processo da regionalização ressaem-se no registro de mudanças nas formas de funcionamento dos sistemas estaduais, na coordenação intergovernamental ou ainda nas estruturas e papel da esfera estadual. Também podem ser observados impactos nas capacidades e formas de organização dos cidadãos, dos agentes provedores, enfim, de todas novas formas associativas decorrentes ou induzidas pelo processo de regionalização. Estes impactos podem ser radicais, incrementais, embrionários ou ausentes, levando-se em conta o ponto de partida, a intensidade e as velocidades das mudanças.

O estudo produziu ainda uma análise detalhada da atuação das Comissões Intergestores Bipartite (CIB) nos 24 estados pesquisados, entre 2007 e 2010. O principal objetivo foi compreender o papel da CIB no processo de regionalização nos estados, se a atuação das comissões foi um fator crucial para induzir a regionalização e se favoreceu a coordenação federativa, a institucionalidade e governança desse processo, assim como, se a regionalização induziu mudanças no papel e na forma de atuação das CIB.

A análise da dinâmica das CIB e sua relação com o processo de regionalização considerou a institucionalidade da comissão, o conteúdo das negociações intergovernamentais, o processo político e a capacidade de atuação. A institucionalidade da $C I B$ valorizou aspectos normativos, cognitivos e políticos que lhe conferem densidade e legitimidade como instância de negociação intergovernamental. O conteúdo das negociações intergovernamentais considerou a diversidade dos temas tratados, a capacidade de adaptação das políticas nacionais à realidade estadual e o poder dos governos estaduais e municipais na construção da agenda da comissão. O processo político referiu-se ao perfil e intensidade das relações intergovernamentais na CIB, identificando convergências ou divergências dos interesses em relação aos assuntos tratados, a frequência, regularidade e formalidade das relações estabelecidas. A capacidade de atuação da CIB concerne a sua habilidade em formular e implementar políticas, bem como em estabelecer parcerias entre governos estaduais e municipais para a solução de problemas loco 
regionais. Analisou-se ainda, dentre outras variáveis, o papel da CIB no processo de regionalização e a presença da regionalização na agenda de discussão da CIB. 
Quadro 7 - Referencial analítico da pesquisa

\begin{tabular}{|c|c|c|c|}
\hline Dimensões & Categorias & Elementos principais & $\begin{array}{c}\text { Influência e padrões } \\
\text { predominantes }\end{array}$ \\
\hline \multirow[t]{3}{*}{ Contexto } & Histórico-estrutural & $\begin{array}{l}\text { - Histórico de conformação do estado e de suas regiões } \\
\text { - Dinâmica socioeconômica e territorial do estado }\end{array}$ & $\begin{array}{l}\text { - Favorável } \\
\text { - Desfavorável } \\
\text { - Indefinido }\end{array}$ \\
\hline & Político-institucional & $\begin{array}{l}\text { - Trajetória da política de saúde e da regionalização no estado } \\
\text { - Modo de funcionamento das instituições políticas e regras da saúde } \\
\text { - Peso do privado na rede de serviços } \\
\text { - Papel desempenhado pelas organizações no sistema de saúde (secretaria estadual e } \\
\text { municipais, COSEMS, CIB) }\end{array}$ & $\begin{array}{l}\text { - Favorável } \\
\text { - Desfavorável } \\
\text { - Indefinido }\end{array}$ \\
\hline & Conjuntural & $\begin{array}{l}\text { - Prioridade da regionalização na agenda dos governos e da Secretaria de Estado de } \\
\text { Saúde } \\
\text { - Situação político-econômica do estado } \\
\text { - Perfil dos dirigentes da saúde }\end{array}$ & $\begin{array}{l}\text { - Favorável } \\
\text { - Desfavorável } \\
\text { - Indefinido }\end{array}$ \\
\hline \multirow[t]{3}{*}{ Direcionalidade } & Ideologia & $\begin{array}{l}\text { - Gerencial: foco nas mudanças organizacionais do Estado para atuação na saúde } \\
\text { - Econômico-mercantil: mercantilização da provisão dos serviços e estímulo à } \\
\text { corresponsabilização privada no financiamento das ações e serviços } \\
\text { - Democrática-participativa: ampliação da participação dos atores envolvidos } \\
\text { - Equidade: melhoria das condições de saúde, ampliação do acesso e integralidade } \\
\text { - Determinantes sociais: articulação de políticas voltadas para a promoção da saúde } \\
\text { - Desenvolvimentismo: articulação de políticas sociais e econômicas voltadas para } \\
\text { o desenvolvimento e bem-estar }\end{array}$ & - não se aplica \\
\hline & Objeto & $\begin{array}{l}\text { - Definição de região: delimitação territorial para organização do sistema de saúde } \\
\text { - Organização de redes e fluxos: definição de polos, integração e articulação de } \\
\text { ações e serviços, sistema de referência e contrarreferência e dos fluxos de } \\
\text { encaminhamento } \\
\text { - Ampliação da capacidade instalada: investimentos/credenciamento de serviços }\end{array}$ & - não se aplica \\
\hline & Atores & $\begin{array}{l}\text { - Institucionais: das três esferas de governo e instâncias colegiadas do SUS (CIB, } \\
\text { Conselho Estadual de Saúde, COSEMS, Conselho de Gestão Regional) } \\
\text { - Prestadores privados } \\
\text { - Associações e organizações da sociedade civil }\end{array}$ & - não se aplica \\
\hline
\end{tabular}




\begin{tabular}{|c|c|c|c|}
\hline & Estratégias & $\begin{array}{l}\text { - Criação ou fortalecimento de instâncias de pactuação e coordenação regional } \\
\text { - Criação e revisão de instrumentos } \\
\text { - Reformas administrativas das Secretarias de Saúde } \\
\text { - Ampliação de recursos financeiros } \\
\text { - Ampliação de atores (públicos e privados, governamentais ou não } \\
\text { governamentais) }\end{array}$ & - não se aplica \\
\hline & Instrumentos & $\begin{array}{l}\text { - Legislação, normas, incentivos, investimentos, planos, mudanças de estruturas } \\
\text { administrativas, contratualização, processos participativos, capacitação, regulação } \\
\text { da assistência, consórcios. }\end{array}$ & - não se aplica \\
\hline \multirow[t]{2}{*}{$\begin{array}{l}\text { Características da } \\
\text { regionalização }\end{array}$} & $\begin{array}{l}\text { Institucionalidade da } \\
\text { regionalização }\end{array}$ & $\begin{array}{l}\text { - Histórico da regionalização, elementos e critérios regionais } \\
\text { - Definição/implantação de estratégias de planejamento e regulação voltadas para } \\
\text { coordenação de açães, serviços e intervenções sanitárias em âmbito regional } \\
\text { - Definição/implantação de mecanismos de financiamento/investimentos voltados } \\
\text { para a regionalização } \\
\text { - Papel da Secretaria de Estado de Saúde na condução da regionalização: estruturas } \\
\text { de coordenação definidas, existência de estratégias políticas }\end{array}$ & $\begin{array}{l}\text { - Avançada } \\
\text { - Intermediária } \\
\text { - Incipiente }\end{array}$ \\
\hline & $\begin{array}{l}\text { Governança da } \\
\text { regionalização }\end{array}$ & $\begin{array}{l}\text { - Diversidade de atores e instâncias com peso na regionalização } \\
\text { - Existência de mecanismos de coordenação das ações conduzidas pelos atores com } \\
\text { peso na regionalização } \\
\text { - Natureza das relações intergovernamentais e entre governos e organizações } \\
\text { - Importância da CIB na regionalização }\end{array}$ & $\begin{array}{l}\text { - Coordenada/ } \\
\text { cooperativa } \\
\text { - Cooperativa } \\
\text { - Coordenada/ conflitiva } \\
\text { - Conflitiva } \\
\text { - Indefinida }\end{array}$ \\
\hline \multirow[t]{2}{*}{$\begin{array}{l}\text { Dinâmica das } \\
\text { Comissões } \\
\text { Intergestores } \\
\text { Bipartite }\end{array}$} & Institucionalidade da CIB & $\begin{array}{l}\text { - Presença de instâncias de integração e processamento técnico-político dos temas } \\
\text { tratados (ex: Câmara Técnica, Grupos de Trabalho ou outras estruturas similares) } \\
\text { - Regularidade de funcionamento da plenária da CIB e suas estruturas de } \\
\text { organização interna (Câmara Técnica, etc.) } \\
\text { - Existência de representatividade regional (por meio da escolha de representantes } \\
\text { ou do funcionamento regular de instâncias regionais) } \\
\text { - Legitimidade da CIB como instância de negociação e decisão técnico-política } \\
\text { (inclui legitimidade dos membros estaduais e municipais) }\end{array}$ & $\begin{array}{l}\text {-Avançada } \\
\text {-Intermediária } \\
\text {-Incipiente }\end{array}$ \\
\hline & $\begin{array}{l}\text { Conteúdo das negociações } \\
\text { intergovernamentais }\end{array}$ & $\begin{array}{l}\text { - Diversidade da temática } \\
\text { - Presença de assuntos/questões relacionados ao estado (próprios do estado, das } \\
\text { suas regióes e seus municípios); capacidade de adaptação à realidade estadual } \\
\text { - Construção conjunta da agenda com relativo equilíbrio de poderes entre os }\end{array}$ & $\begin{array}{l}\text { - Diversificada ou restrita } \\
\text { - Aderente ou não } \\
\text { aderente } \\
\text { - Compartilhada ou não }\end{array}$ \\
\hline
\end{tabular}




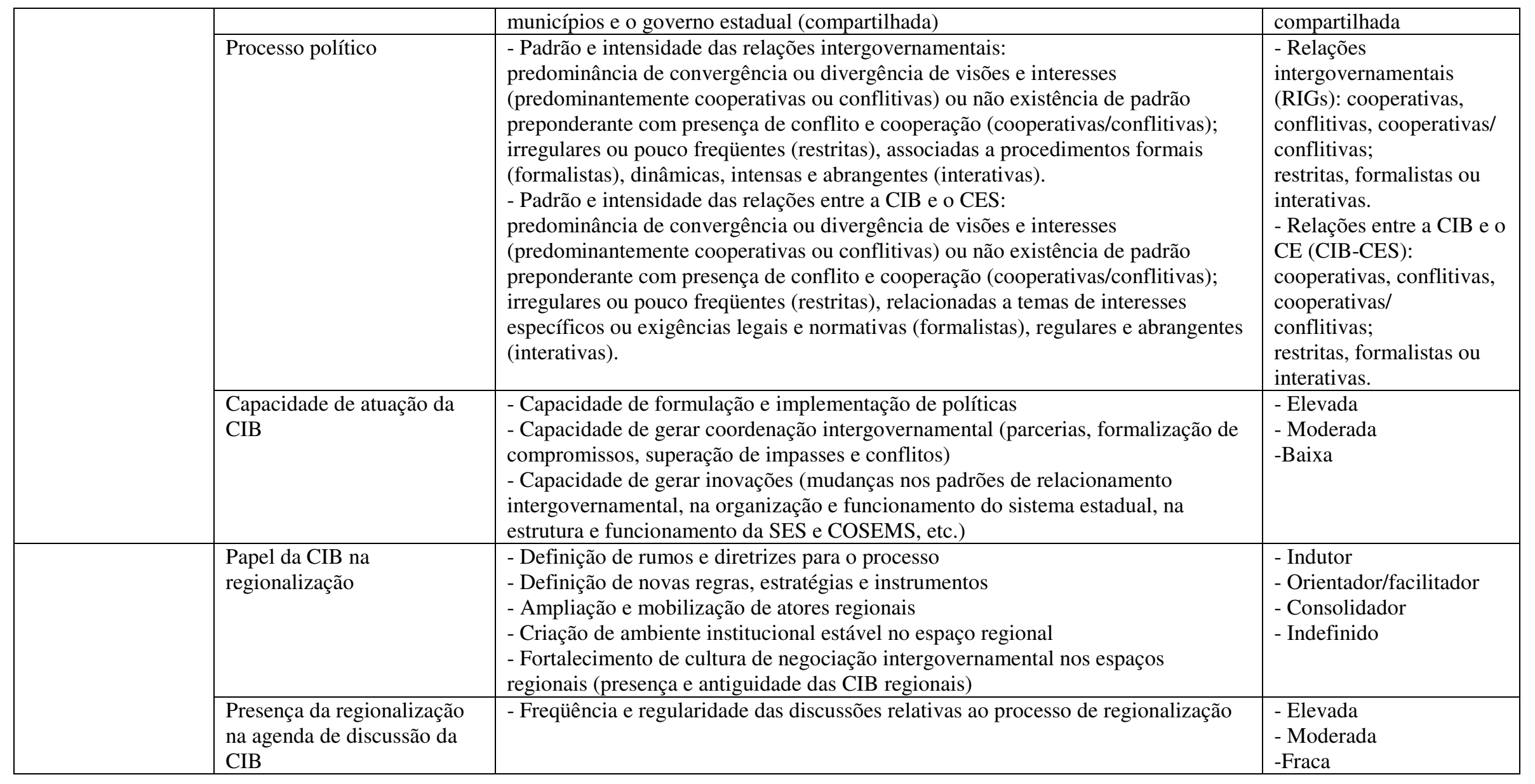

Fonte: adaptado de Viana \& Lima, 2011 (p.178-180) e Lima et al., 2012 (p.2884-2885). 
Outros elementos condicionantes do processo de regionalização nos estados, tais como as variáveis econômicas e sociais e de conformação do sistema de saúde (capacidade instalada e cobertura, complexidade e perfil público-privado da oferta de ações e serviços de saúde), foram abordados pelo estudo na elaboração de uma tipologia das regiões de saúde constituídas (VIANA, LIMA \& FERREIRA, 2010; FERREIRA \& DINI, 2011). Os arranjos público-privados regionais em saúde foram avaliados por estudos de caso específicos, orientados por referenciais metodológicos apropriados.

Outra variável que influencia a regionalização são os recursos disponíveis para o gasto público em saúde, altamente dependentes da capacidade de arrecadação própria e das transferências federais do SUS para os estados e municípios. O estudo não realizou análises específicas por região de saúde, mas um levantamento dos gastos por ano e esfera governamental (LEVI \& SCATENA, 2011).

Os resultados ${ }^{121}$ do estudo coordenado por Viana \& Lima (2011) apontaram os diferentes estágios e condicionantes da regionalização do SUS nos estados brasileiros e identificaram mudanças importantes no exercício do poder no âmbito da política de saúde, no período analisado (2007-2010). Possibilitaram verificar o grau de institucionalidade e governança que o processo de regionalização alcança nos estados brasileiros e a influência mais ou menos favorável dos contextos históricoestrutural, político-institucional e conjuntural sobre esse processo.

Embora cada estado tenha sido abordado individualmente, optou-se aqui por analisar os resultados do estudo agregados por grandes regiões brasileiras, seguindo a

\footnotetext{
${ }^{121} \mathrm{O}$ trabalho de campo do estudo foi realizado por duplas de pesquisadores em todas as unidades federativas, à exceção dos estados de Maranhão e Tocantins (decorrência da instabilidade política gerada pela troca de seus governos estaduais no período programado para o campo). Durante as visitas aos estados, foram realizadas entrevistas semidirigidas direcionadas inicialmente ao gestor estadual, ao responsável pela regionalização da Secretaria de Estado da Saúde (SES), ao presidente do Conselho de Secretários Municipais de Saúde (Cosems) e ao Secretário Executivo da Comissão Intergestores Bipartite, CIB (não raro, e por motivos diversos, as entrevistas foram realizadas com seus representantes). Considerando o período privilegiado na pesquisa (2007 a 2010), foi ainda realizada uma revisão extensiva de documentos relacionados ao processo de regionalização nos estados (Plano Plurianual, Plano Estadual de Saúde, Plano Diretor de Regionalização, Plano Diretor de Investimentos, Programação Pactuada e Integrada; normativas; Regimento Interno, atas, resoluções e deliberações das CIB; documentos relativos aos Colegiados de Gestão Regional (CGR), entre outros), além da observação de reuniões das CIB e de outras relacionadas com o tema naqueles estados em que houve coincidência daquelas com a agenda de pesquisa. No total, foram visitados 24 estados e realizadas 91 entrevistas com 103 dirigentes e técnicos: Secretários de Estado de Saúde, Presidentes do Cosems, responsáveis pela regionalização nos estados, Secretários Executivos das CIB.
} 
divisão dos "quatro Brasis" proposta por Santos \& Silveira (2001): Amazônia, Nordeste, Centro-Oeste e Região Concentrada.

A regionalização da saúde é uma estratégia setorial que incide sobre distintos contextos, situações geográficas e de saúde, combinando diretrizes nacionais e variáveis locais, regionais, estaduais e macrorregionais da conformação do sistema e das políticas de saúde.

Existem especificidades do processo de regionalização do SUS que são condicionadas pelas situações geográficas que caracterizam os "quatro Brasis". Fica evidente a importância do olhar sobre a difusão heterogênea do atual meio técnicocientífico-informacional e das heranças dos usos do território, conformadas em diferentes períodos históricos, numa perspectiva geral de que essa formação socioespacial e sua divisão territorial do trabalho auxiliem na compreensão das desigualdades territoriais que marcam o país no período, incluindo aquelas diretamente ligadas à conformação do sistema e das políticas de saúde. O SUS concretizado no território, isto é, como se reafirma na divisão territorial do trabalho na saúde, também expressa diversidades e desigualdades técnicas e políticoinstitucionais parecida com a divisão dos "quatro Brasis", com o comando técnico e político concentrado nas cidades médias, capitais e regiões metropolitanas.

A diferenciação regional dos "quatro Brasis" identifica distintas situações geográficas que marcam o território brasileiro no período da globalização. De acordo com Silveira (1999), a situação geográfica diz respeito à forma como cada lugar ou região se insere no processo de modernização e recebe as variáveis do período atual, revelando a direção e o sentido que orientam a evolução dos usos do território e do papel do lugar na divisão territorial do trabalho. As situações são condicionadas pelas heranças histórico-estruturais e pelos novos eventos (materialidades, normas e ações) que se realizam, combinando forças internas e externas aos lugares. As situações são uma tentativa de síntese da relação do lugar com o mundo.

A situação decorreria de um conjunto de forças, isto é, de um conjunto de eventos geografizados, porque tornados materialidade e norma. Muda, paralelamente, o valor dos lugares porque muda a situação, criando uma nova geografia. Assim, ao longo do tempo, os eventos constroem situações geográficas que podem ser demarcadas em períodos e analisadas na sua coerência. /.../ Os participantes da situação não têm obrigatoriamente intencionalidade coincidentes explícitas, mas suas 
atividades possuem um tema comum que define a natureza do seu esforço. (SILVEIRA, 1999, p.22-23)

O conceito de situações geográficas tem contribuído para análises regionais das políticas de saúde. Na medida em que a conformação do sistema e das políticas de saúde é também condicionada pelos usos do território e suas modernizações, a identificação de situações geográficas ajuda a revelar sentidos e direções históricoestruturais e conjunturais da universalização da saúde nos lugares e regiões (ALBUQUERQUE, 2006, 2008; VIANA et al., 2007, 2011). As situações permitem identificar o sentido dos desafios postos pela dimensão territorial às políticas de saúde, e lançam uma âncora no futuro sobre as possibilidades da consolidação do SUS e da universalização da saúde em cada lugar (ALBUQUERQUE, 2006). O conceito ajuda a revelar as diferentes respostas oferecidas pelos lugares ao projeto de universalização da saúde e como os desafios colocados se intensificam conforme a situação geográfica (VIANA et al., 2007, 2011).

Apoiados por pesquisas diversas, Santos \& Silveira (2001, p.268) dividiram o território brasileiro grosso modo em quatro regiões ou "quatro Brasis" (Fig. 2): Amazônia, Nordeste, Centro-Oeste e Região Concentrada. Trata-se de compreender como a expansão e concentração das variáveis do meio geográfico (ciência, tecnologia, norma e informação) e a inserção do país na divisão internacional do trabalho possibilitam usos do território e diferenciam grandes regiões, de acordo com o sentido das modernizações e das desigualdades que abrigam.

La historia del uso del territorio es un camino de etapas, desde el medio natural al medio técnico y al medio técnico-científico-informacional (Santos, 1988; 1996). El uso del territorio se define por la implantación de infraestructuras o sistemas de ingeniería, pero también por el dinamismo de la economía y de la sociedad. Son los movimientos de la población, la distribución de la agricultura, de la industria y de los servicios, la estructura normativa, incluyendo la legislación civil, fiscal y financiera que, junto con el alcance y la extensión de la ciudadanía, configuran las funciones del nuevo medio geográfico. (...)

Cuatro largos períodos pueden explicar la historia del uso del territorio brasileño. Primero, la presencia humana, indígena y europea se adaptaba a los sistemas naturales con escasas técnicas. Desde el siglo XVIII la mecanización selectiva de la producción, a partir del nordeste, da origen a un Brasil archipiélago. En un tercer momento, la mecanización de la circulación permite la integración del territorio y del mercado, con un significativo proceso de industrialización de hegemonía paulista durante 
la primera mitad del siglo XX. A partir de las últimas décadas del siglo, con la revolución de las telecomunicaciones, de la ciencia, de la información y de las finanzas aumentan las diferencias regionales, la urbanización y la metropolización. Crece la importancia de las regiones sudeste y sur, así como de las regiones periféricas con producciones modernas. (SILVEIRA, 2007).

A Região Concentrada, abrangendo São Paulo, Rio de Janeiro, Minas Gerais, Espírito Santo, Paraná, Santa Catarina e Rio Grande do Sul, se caracteriza pela mais alta concentração da população, das tecnologias, das normas, da produção científica, dos serviços e atividades produtivas públicas e privadas, das redes, dos fluxos materiais, populacionais, informacionais e financeiros, pela consolidação (densa e contínua) do meio técnico-científico-informacional e do processo de urbanização e pelo poder político e econômico de comando dos usos do território e suas interconexões nacionais, em comparação às outras regiões. São Paulo constitui-se o grande polo de comando sobre a economia nacional (BERNARDES, 2001; SILVEIRA, 2007).

A Região Centro-Oeste, abrangendo Mato Grosso, Mato Grosso do Sul, Goiás e Tocantins, se caracteriza por ser uma área de modernização recente e intensa, ligada ao novo front de produção agrícola globalizada (commodities para exportação e consumo interno), com rápida e crescente urbanização e densificação técnica, científica, informacional e populacional, exercendo atração de empresas especializadas e trabalhadores qualificados provenientes da região concentrada. Uma região com forte inserção na divisão internacional do trabalho no período da globalização.

A Região Nordeste, abrangendo Maranhão, Piauí, Ceará, Rio Grande do Norte, Paraíba, Pernambuco, Alagoas, Sergipe e Bahia, se caracteriza pelo povoamento antigo, pouco denso, integrado e mecanizado, e por uma difusão mais pontual (manchas) do meio técnico-científico-informacional, da urbanização, da produção agrícola moderna e dos fluxos materiais e informacionais em alguns polos regionais e nas capitais. O Nordeste enfrenta processos históricos de concentração de terras e uma urbanização bastante desigual, decorrente das oscilações da dinâmica econômica regional e/ou do papel político de cada cidade (SILVEIRA, 2007).

A Amazônia, abrangendo Pará, Amapá, Roraima, Amazonas, Acre e Rondônia, representaria a difusão mais pontual e menos densa dos sucessivos meios 
geográficos que marcaram cada período histórico, incluindo o meio técnicocientífico-informacional, sendo caracterizada pela rarefação e descontinuidade da rede urbana e das redes de transporte e comunicação. A região é marcada por grandes migrações externas e internas, pela diversidade sociocultural e pelos conflitos das disputas pela terra. Também se caracteriza pelas oscilações da dinâmica econômica em função de grandes projetos de investimento em agropecuária, mineração, energia e transportes, da existência de áreas de conservação e de grandes frentes de expansão econômica. A região conta com duas metrópoles e poucos polos regionais.

\section{Figura 2 - Regiões brasileiras no período da globalização}

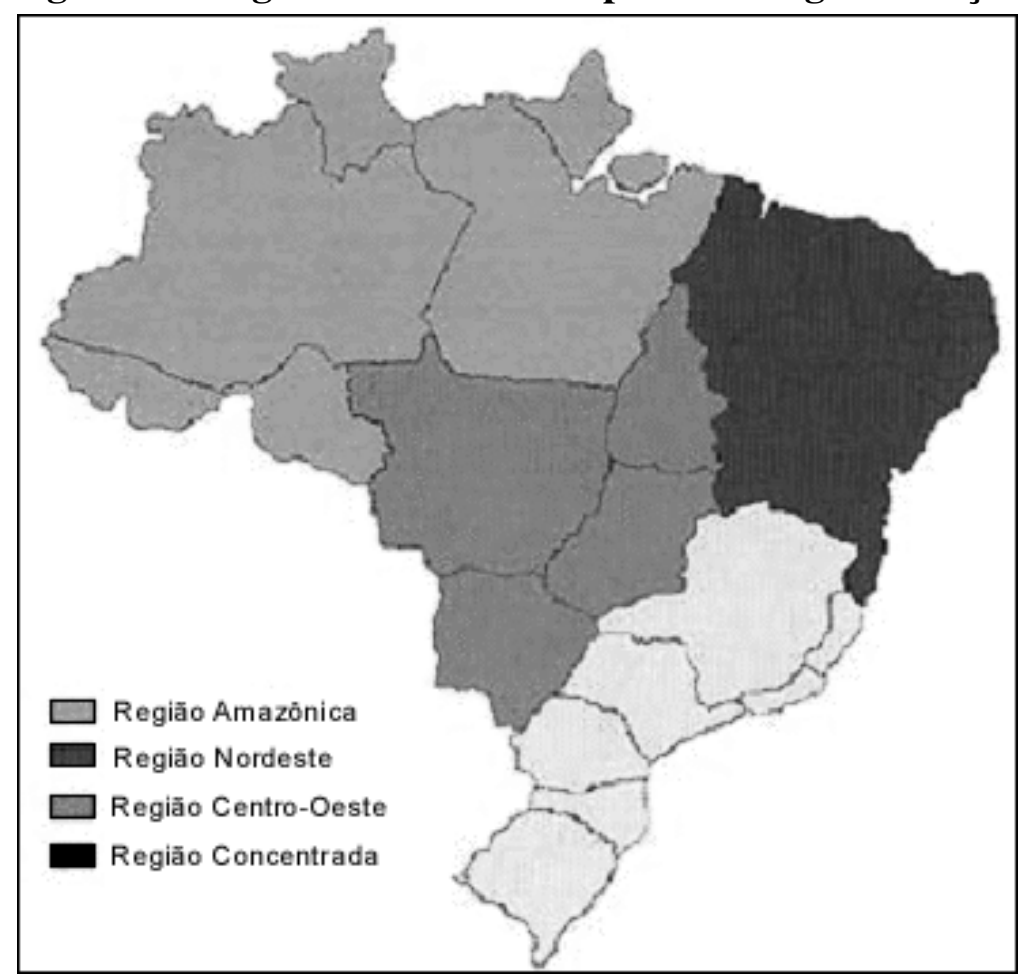

Fonte: Santos \& Silveira, 2001.

A diferenciação regional dos "quatro Brasis" cria uma escala de análise intermediária entre a nacional e a estadual, favorecendo a compreensão sobre os condicionantes territoriais (território usado) da conformação do sistema e das políticas de saúde, incluindo a estratégia de regionalização do SUS. Identificando, neste caso, desafios e limitações compartilhados por mais de um estado dentro de uma mesma região. 
As situações geográficas que diferenciam as quatro grandes regiões ajudam a analisar, por exemplo, as razões para a existência de contextos menos favoráveis à regionalização do SUS nos estados da Amazônia e mais favoráveis nos estados da Região Concentrada.

Dos resultados apresentados pelo estudo de Viana \& Lima (2011), três aspectos apresentaram uma caracterização muito próxima à tendência de diferenciação regional dos "quatro Brasis", influenciando fortemente a institucionalidade e a governança da regionalização do SUS nos estados localizados numa mesma região.

O primeiro aspecto relaciona-se à tipologia criada para caracterizar as regiões de saúde segundo a situação socioeconômica dos municípios e oferta e complexidade dos serviços de saúde existentes. O segundo aspecto diz respeito aos contextos histórico-estruturais e político-institucionais, conforme as tendências mais ou menos favoráveis que eles representam para o processo de regionalização do SUS nos estados. O terceiro aspecto relaciona-se ao grau de institucionalidade e à capacidade de atuação das Comissões Intergestores Bipartite (CIB).

A tipologia nacional das 431 Comissões Intergestores Regionais (CIRs) baseou-se em indicadores municipais ${ }^{122}$ agregados em duas dimensões ${ }^{123}$ : situação socioeconômica e oferta e complexidade dos serviços de saúde. O resultado foi a identificação de 5 (cinco) grupos com características bastante distintas quanto às dimensões utilizadas (Tabela 3, Figura 3).

\footnotetext{
${ }^{122}$ As fontes de dados utilizadas foram o Censo Demográfico 2010 realizado pelo Instituto Brasileiro de Geografia e Estatística - IBGE; os Bancos de Dados do Sistema Único de Saúde disponíveis no Datasus (www.datasus.gov.br); a Relação Anual de Informações Sociais - RAIS, disponibilizado anualmente pelo Ministério do Trabalho (www.mte.gov.br) e o Sistema de Contas Regionais - IBGE. (FERREIRA \& DINI, 2011).

${ }^{123}$ Variáveis utilizadas na construção da tipologia: Situação socioeconômica: renda per capita, PIB per capita, nível de escolarização, densidade populacional; Oferta e complexidade dos serviços de saúde: leitos por habitantes, médicos por habitantes, beneficiários de planos de saúde e internações de alta complexidade no SUS em relação ao total de internações. A situação socioeconômica relacionase ao grau de desenvolvimento socioeconômico dos municípios pertencentes às CIR. As CIR que atingem os maiores valores nesse indicador caracterizam-se por agruparem os municípios mais urbanizados, populosos, industrializados e dinâmicos economicamente. A oferta e complexidade dos serviços de saúde relacionam-se à complexidade dos serviços ofertados nos municípios pertencentes às CIR, maiores valores nesse fator indicam maior oferta e complexidade do sistema de saúde. (FERREIRA \& DINI, 2011).
} 
- $\quad$ Grupo 1 - baixo desenvolvimento socioeconômico e baixa oferta de serviços: inclui 178 CIRs, $39 \%$ dos municípios e 22,8\% da população do Brasil no ano de 2010. $82 \%$ dessas CIRs estão localizadas nas regiões Norte e Nordeste

- Grupo 2 - médio/alto desenvolvimento socioeconômico e baixa oferta de serviços: inclui 56 CIRs, 10,3\% municípios e 6,6\% da população do Brasil no ano de 2010. 89\% dessas CIRs estão localizadas nas regiões Norte, CentroOeste e Sudeste (Norte de Minas e Vale do Ribeira em São Paulo)

- Grupo 3 - médio desenvolvimento socioeconômico e média oferta de serviços: inclui 108 CIRs, 30,7\% dos municípios e 18,5\% da população do Brasil no ano de 2010. 84\% dessas CIRs estão localizadas nas Sudeste e Sul

- $\quad$ Grupo 4 - alto desenvolvimento socioeconômico e média oferta de serviços: inclui 46 CIRs, 9,8\% dos municípios e 14,8\% da população do Brasil no ano de 2010. 83\% dessas CIRs estão localizadas nas Sudeste e Sul

- Grupo 5 - alto desenvolvimento socioeconômico e alta oferta de serviços: inclui 43 CIRs, 565 municípios e 37,4\% da população do Brasil no ano de 2010. $70 \%$ dessas CIRs estão localizadas nas Sudeste e Sul.

Tabela 3 - Principais características dos agrupamentos das CIR

\begin{tabular}{lccccc}
\hline Características & Grupo & Grupo & Grupo 3 & Grupo & Grupo 5 \\
\hline Número de CIR & 178 & 56 & 108 & 46 & 43 \\
\hline \% no total de CIR & 41,3 & 13,0 & 25,1 & 10,7 & 10,0 \\
\hline Número de Municípios & 2.172 & 574 & 1.706 & 548 & 565 \\
\hline \% no total de municípios & 39,0 & 10,3 & 30,7 & 9,8 & 10,2 \\
\hline \% no total da população & 22,8 & 6,6 & 18,5 & 14,8 & 37,4 \\
\hline Média de municípios por CIR & 12 & 10 & 16 & 12 & 13 \\
\hline Média da população por município & 20.162 & 22.003 & 20.818 & 51.852 & 127.480 \\
\hline $\begin{array}{l}\text { Beneficiários de plano de saúde na } \\
\text { população (\%) }\end{array}$ & 1,3 & 2,4 & 4,0 & 8,4 & 16,4 \\
\hline População cadastrada na ESF (\%) & 78,2 & 66,6 & 60,0 & 38,1 & 27,6 \\
\hline Médicos por mil habitantes & 0,50 & 0,78 & 1,24 & 1,43 & 2,29 \\
\hline Médicos SUS no total de médicos (\%) & 92,3 & 86,0 & 84,0 & 76,6 & 68,2 \\
\hline Leitos por mil habitantes & 1,8 & 1,9 & 2,7 & 2,0 & 2,8 \\
\hline Leitos SUS no total de leitos (\%) & 89,5 & 76,3 & 75,3 & 68,8 & 64,3 \\
\hline $\begin{array}{l}\text { Despesas totais em saúde por habitante } \\
\text { (R\$ de 2010) }\end{array}$ & 278 & 338 & 369 & 411 & 401 \\
\hline $\begin{array}{l}\text { Transferência SUS por habitante (R\$ } \\
\text { de 2010) }\end{array}$ & 148 & 147 & 159 & 147 & 157 \\
\hline $\begin{array}{l}\text { Transferência SUS na despesa total em } \\
\text { saúde (\%) }\end{array}$ & 53,4 & 43,6 & 43,0 & 35,8 & 39,3 \\
\hline
\end{tabular}

Fonte: Base de Indicadores das Comissões Intergestores Regionais. Disponível em: http://jamnconsultoria.com.br/projetos/bicir/view/index.php. Acesso em 29 agosto 2013.

A tipologia das regiões de saúde dialoga com os "quatro Brasis" a partir das desigualdades que ela expressa (Fig. 3): na Amazônia e no Nordeste localizam-se os 
grupos com níveis mais baixos de desenvolvimento socioeconômico e menor oferta de serviços de saúde; por outro lado, a Região Concentrada abriga os grupos com desenvolvimento socioeconômico mais elevado e maior oferta de serviços.

\section{Figura 3 - Tipologia das regiões de saúde no Brasil (2010)}

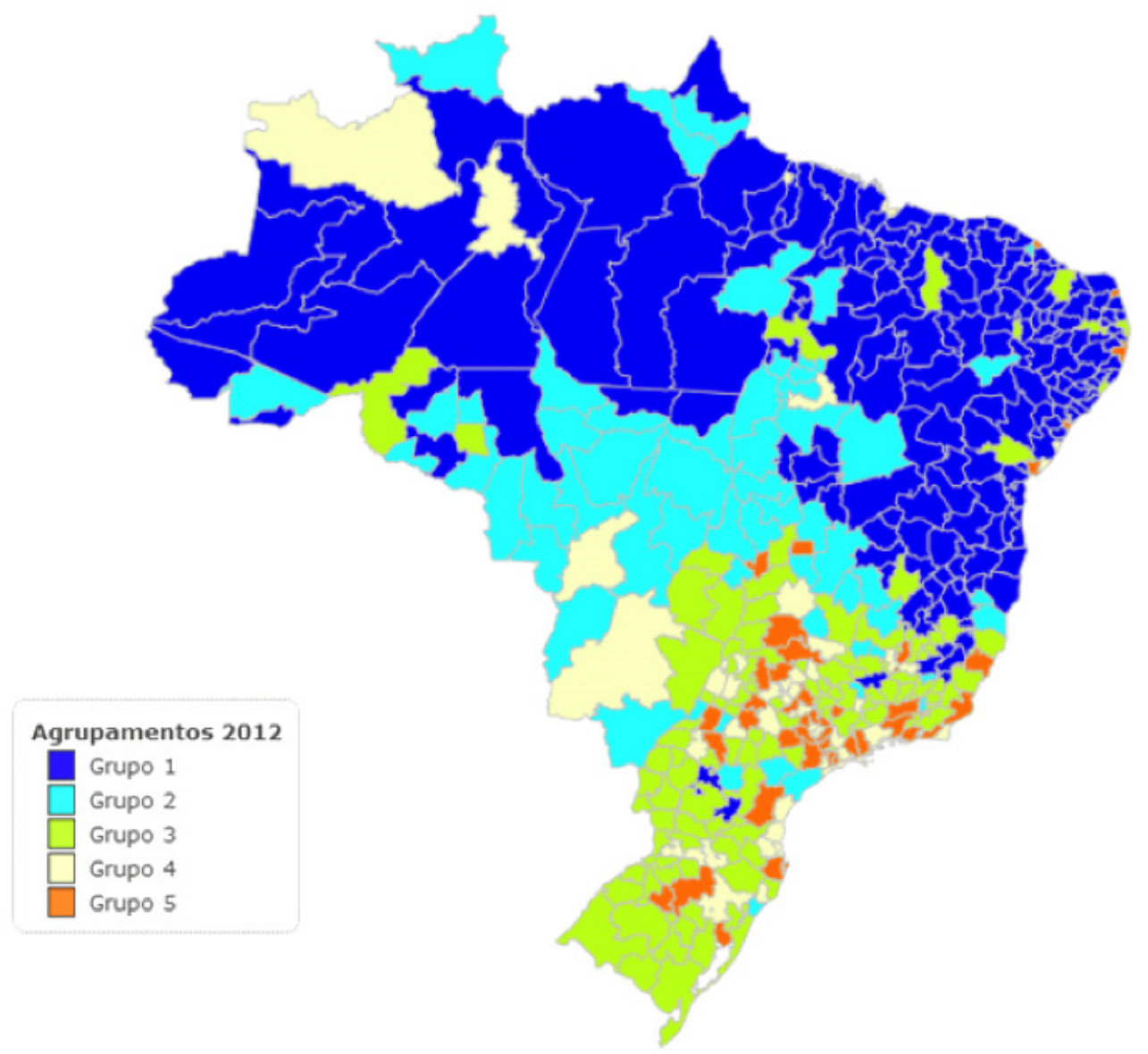

Fonte: Base de Indicadores das Comissões Intergestores Regionais- CIR formalmente constituídas até 12 de setembro de 2012. Disponível em: http://jamnconsultoria.com.br/projetos/bicir/view/index.php. Acesso em 29 agosto 2013.

Grupo 1 - baixo desenvolvimento socioeconômico e baixa oferta de serviços

Grupo 2 - médio/alto desenvolvimento socioeconômico e baixa oferta de serviços

Grupo 3 - médio desenvolvimento socioeconômico e média oferta de serviços

Grupo 4 - alto desenvolvimento socioeconômico e média oferta de serviços

Grupo 5 - alto desenvolvimento socioeconômico e alta oferta de serviços

Os resultados em relação às tendências mais ou menos favoráveis dos contextos histórico-estruturais e político-institucionais sobre a regionalização do SUS, sua institucionalidade e governança também dialogam com os "quatro Brasis" (Quadro 8).

Os estados localizados na Amazônia e no Nordeste apresentaram os contextos histórico-estruturais e político-institucionais mais desfavoráveis ao processo de 
regionalização do SUS, sendo que situação inversa se observa nas demais regiões. Por outro lado, em nenhum dos estados visitados a conjuntura política foi avaliada como desfavorável, embora a situação se apresente em contornos nitidamente mais indefinidos para os estados da Amazônia.

$\mathrm{Na}$ maior parte dos estados brasileiros verifica-se uma institucionalidade intermediária do processo de regionalização e uma governança cooperativa ou coordenada-cooperativa. Identifica-se também a predominância de impactos e inovações institucionais incrementais (Quadro 8, Fig.6).

$\mathrm{Na}$ Amazônia, a institucionalidade da regionalização variou entre incipiente e intermediária e a governança, quando definida, apresentou padrão mais cooperativo e coordenado. Os impactos e inovações institucionais, quando existentes, foram predominantemente embrionários.

No Nordeste, a institucionalidade da regionalização variou de incipiente a avançada, com predominância de uma institucionalidade intermediária nos estados. A governança, quando definida, apresentou padrão mais cooperativo e coordenado. Observa-se a existência de impactos e inovações institucionais relacionados à regionalização em todos os estados, com predomínio daqueles caracterizados como incrementais. Destaca-se que em apenas dois dos estados analisados em todo o país, que se localizam no Nordeste, foram identificados impactos e inovações institucionais radicais.

No Centro-Oeste, a institucionalidade da regionalização apresentou padrão avançado e intermediário, com predomínio deste, e a governança caracterizou-se pelas relações coordenadas e cooperativas, sendo indefinida para um estado. Os impactos e inovações institucionais da regionalização do SUS foram classificados como incrementais.

Na Região Concentrada, a institucionalidade da regionalização apresentou padrão intermediário e avançado, e a governança se caracterizou pela predominância de relações coordenadas e cooperativas, sendo indefinida apenas para um estado. Os impactos e inovações institucionais relacionados ao processo foram incrementais, com exceção de um estado (embrionários). 
Quadro 8 - Contextos, padrões predominantes de institucionalidade e governança, impactos e inovações do processo de regionalização em saúde nos estados, segundo os "quatro Brasis" - 2007 a 2010

\begin{tabular}{|c|c|c|c|c|c|c|}
\hline & $\begin{array}{l}\text { Histórico- } \\
\text { estrutural }\end{array}$ & $\begin{array}{c}\text { Político- } \\
\text { institucional }\end{array}$ & Conjuntural & Institucionalidade & Governança & $\begin{array}{c}\text { Impactos e } \\
\text { inovações } \\
\text { institucionais }\end{array}$ \\
\hline \multicolumn{7}{|c|}{ AMAZÔNIA } \\
\hline$\overline{A C}$ & $\mathrm{D}$ & $\mathrm{D}$ & $\bar{F}$ & Intermediária & Cooperativa & Incrementais \\
\hline RO & $\mathrm{D}$ & $\mathrm{D}$ & I & Intermediária & $\begin{array}{c}\text { Coordenada- } \\
\text { conflitiva }\end{array}$ & Embrionários \\
\hline $\mathbf{P A}$ & $\mathrm{D}$ & $\mathrm{D}$ & I & Intermediária & Indefinida & Embrionários \\
\hline $\mathbf{A P}$ & $\mathrm{D}$ & $\mathrm{D}$ & $\mathrm{I}$ & Incipiente & Cooperativa & Embrionários \\
\hline $\mathbf{A M}$ & $\mathrm{D}$ & $\mathrm{D}$ & I & Incipiente & Indefinida & Ausentes \\
\hline $\mathbf{R R}$ & D & D & I & Incipiente & Indefinida & Ausentes \\
\hline \multicolumn{7}{|c|}{ NORDESTE } \\
\hline $\mathbf{C E}$ & $\bar{D}$ & $\mathrm{~F}$ & $\bar{F}$ & Avançada & $\begin{array}{l}\text { Coordenada- } \\
\text { cooperativa }\end{array}$ & Incrementais \\
\hline SE & $\mathrm{F}$ & $\mathrm{F}$ & $\mathrm{F}$ & Avançada & $\begin{array}{l}\text { Coordenada- } \\
\text { cooperativa }\end{array}$ & Radicais \\
\hline $\mathbf{R N}$ & $\mathrm{D}$ & $\mathrm{D}$ & I & Intermediária & Cooperativa & Incrementais \\
\hline $\mathbf{P I}$ & $\mathrm{D}$ & $\mathrm{F}$ & $\mathrm{F}$ & Intermediária & Cooperativa & Radicais \\
\hline PE & $\mathrm{D}$ & $\mathrm{D}$ & $\mathrm{F}$ & Intermediária & $\begin{array}{c}\text { Coordenada- } \\
\text { conflitiva }\end{array}$ & Incrementais \\
\hline $\mathbf{B A}$ & $\mathrm{D}$ & $\mathrm{D}$ & $\mathrm{F}$ & Intermediária & Indefinida & Incrementais \\
\hline $\mathbf{A L}$ & $\mathrm{D}$ & $\mathrm{D}$ & I & Incipiente & Conflitiva & Embrionários \\
\hline PB & $\mathrm{D}$ & $\mathrm{D}$ & I & Incipiente & Indefinida & Embrionários \\
\hline MA & NI & NI & NI & NI & NI & NI \\
\hline \multicolumn{7}{|c|}{ Centro-Oeste } \\
\hline MT & $\mathrm{F}$ & $\mathrm{F}$ & $\mathrm{F}$ & Avançada & $\begin{array}{l}\text { Coordenada- } \\
\text { cooperativa }\end{array}$ & Incrementais \\
\hline MS & $\mathrm{F}$ & $\mathrm{F}$ & $\mathrm{F}$ & Intermediária & $\begin{array}{l}\text { Coordenada- } \\
\text { cooperativa }\end{array}$ & Incrementais \\
\hline GO & $\mathrm{F}$ & $\mathrm{D}$ & I & Intermediária & Indefinida & Incrementais \\
\hline TO & NI & NI & NI & NI & NI & NI \\
\hline \multicolumn{7}{|c|}{ REGIÃo CONCENTRADA } \\
\hline MG & $\mathrm{F}$ & $\mathrm{F}$ & $\bar{F}$ & $\overline{\text { Avançada }}$ & $\begin{array}{l}\text { Coordenada- } \\
\text { cooperativa }\end{array}$ & Incrementais \\
\hline PR & $\mathrm{F}$ & $\mathrm{F}$ & $\mathrm{F}$ & Avançada & $\begin{array}{l}\text { Coordenada- } \\
\text { cooperativa }\end{array}$ & Incrementais \\
\hline SP & $\mathrm{F}$ & $\mathrm{F}$ & $\mathrm{F}$ & Avançada & $\begin{array}{l}\text { Coordenada- } \\
\text { cooperativa }\end{array}$ & Incrementais \\
\hline ES & $\mathrm{F}$ & $\mathrm{F}$ & $\mathrm{F}$ & Intermediária & $\begin{array}{l}\text { Coordenada- } \\
\text { cooperativa }\end{array}$ & Incrementais \\
\hline $\mathbf{R S}$ & $\mathrm{F}$ & $\mathrm{F}$ & $\mathrm{F}$ & Intermediária & $\begin{array}{l}\text { Coordenada- } \\
\text { cooperativa }\end{array}$ & Incrementais \\
\hline SC & $\mathrm{F}$ & $\mathrm{D}$ & $\mathrm{F}$ & Intermediária & Cooperativa & Incrementais \\
\hline $\mathbf{R J}$ & $\mathrm{D}$ & $\mathrm{D}$ & I & Intermediária & Indefinida & Embrionários \\
\hline
\end{tabular}

Elaboração própria. Fonte dos dados: Viana \& Lima, 2011.

Nota: F: favorável; D: desfavorável; I: indefinido; NI: Não investigado. 
Verifica-se que os contextos mais favoráveis estão relacionados aos graus mais avançados e intermediários de institucionalidade e à governança mais cooperativa e coordenada (destaca-se neste caso o peso do contexto políticoinstitucional para a caracterização da governança).

\section{Figura 5 - Padrões predominantes de institucionalidade e governança no processo de regionalização da saúde nos estados - Brasil, 2007 a 2010.}

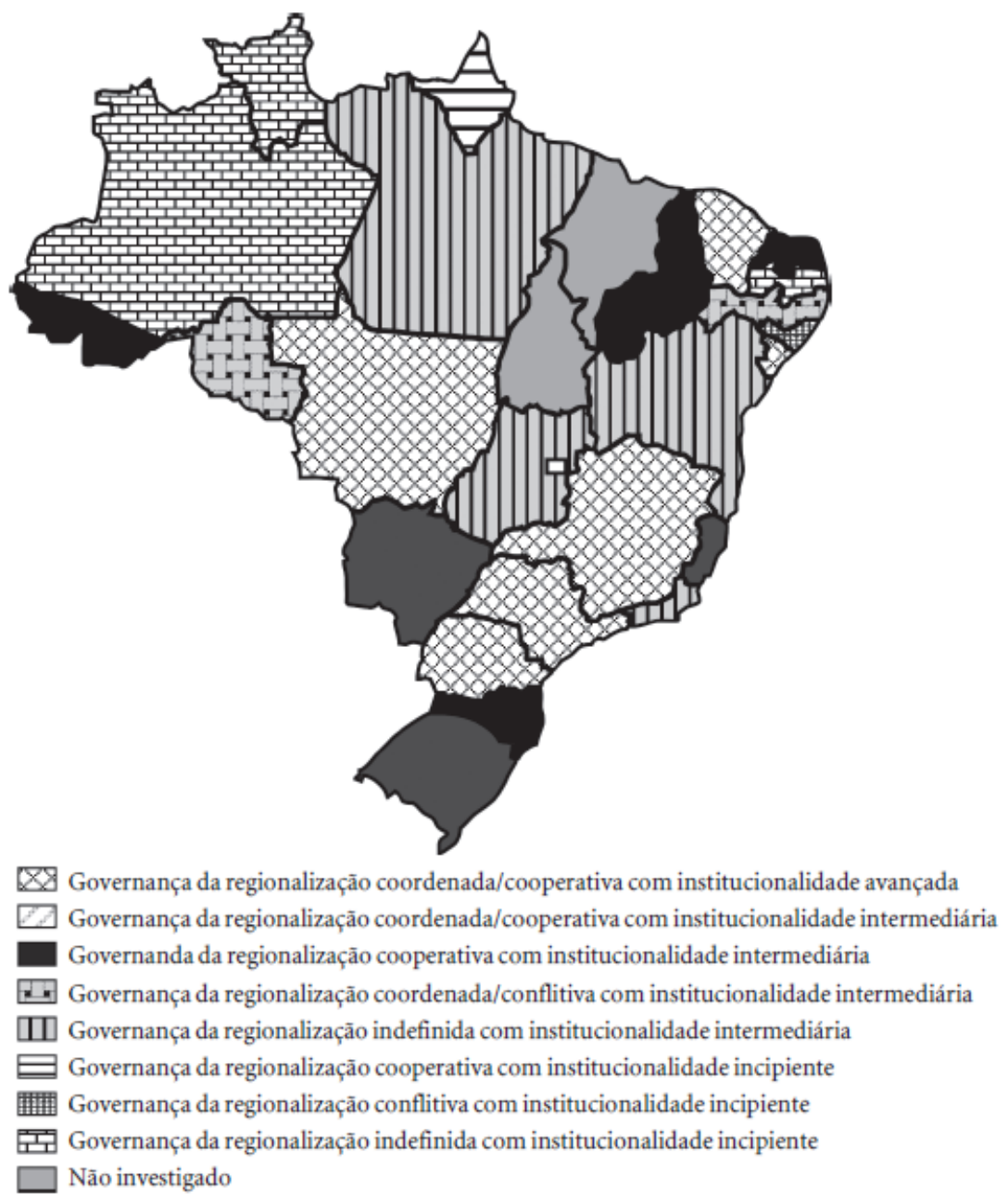

Fonte: Entrevistas e documentos oficiais, elaboração dos autores. Lima et al., 2012.

Os resultados sobre as ideologias que orientam o processo de regionalização nos estados também apresentam variações segundo as quatro grandes regiões brasileiras.

Na maior parte dos estados brasileiros (19 deles) o processo da regionalização em curso está pautado pela ideologia da equidade (Fig. 5), o que a situa como uma das principais estratégias utilizadas pelo poder público para o enfrentamento das 
desigualdades de financiamento e acesso aos serviços, maior obstáculo estrutural para a efetivação da universalização da saúde no país. A orientação para a equidade vem acompanhada da ideologia democrática-participativa em 17 estados; e daquela gerencial em outros 16, levando a crer que o enfrentamento das desigualdades associa-se tanto com a ampliação da diversidade de atores que participam e influenciam os processos decisórios- democratização da decisão pública -, quanto às mudanças na organização e na gestão do sistema, sobretudo no que se refere ao papel do estado na coordenação e planejamento do sistema de saúde.

$\mathrm{Na}$ Amazônia, observa-se o predomínio das ideologias da equidade e gerencial na orientação do processo de regionalização nos estados e a organização de redes e fluxos como objeto principal desse processo.

No Nordeste, observa-se o predomínio das ideologias gerencial, da equidade e democrática na orientação e a organização de redes e fluxos e a ampliação da capacidade instalada como objetos do processo de regionalização nos estados.

Destaca-se que o desenvolvimentismo apareceu como ideologia apenas em quatro estados, localizados na Amazônia e no Nordeste. O desenvolvimentismo, que marcou a gestão federal no período analisado, influenciou a gestão nos estados governados pelo PT e pelo PMDB (partido da base aliada do governo). Os planos de combate às desigualdades regionais elaborados pela gestão federal focaram prioritariamente essas duas regiões, nas escalas macro, meso e microrregionais, por serem historicamente marcadas pelas dificuldades estruturais relacionadas à inserção econômica na divisão internacional do trabalho e à melhoria das condições de vida da população.

No Centro-Oeste, observa-se o predomínio das ideologias gerencial e democrática na orientação do processo de regionalização nos estados e a organização de redes e fluxos e a ampliação da capacidade instalada como objetos desse processo.

Na Região Concentrada, observa-se o predomínio das ideologias gerencial, democrática e da equidade na orientação da regionalização e a organização de redes e fluxos como objeto principal desse processo nos estados. 
Figura 4 - Ideologias e objetos predominantes no processo de regionalização da saúde nos estados - Brasil, 2007 a 2010.

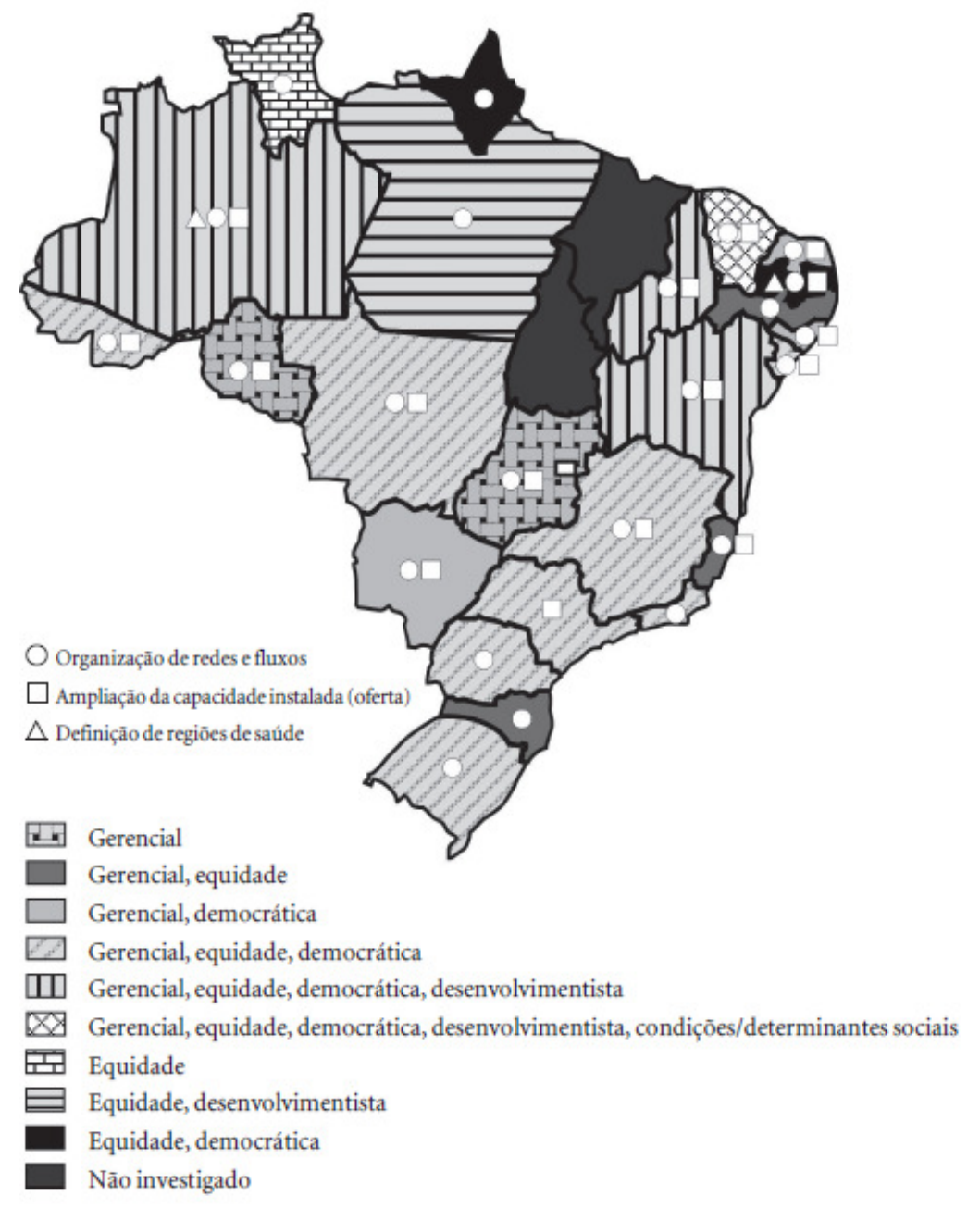

Fonte: Entrevistas e documentos oficiais, elaboração dos autores. Lima et al., 2012.

Os resultados do estudo sobre a dinâmica das Comissões Intergestores Bipartite (CIB) e sua relação com o processo de regionalização nos estados também apontam diferenças regionais importantes. Destaca-se nesse sentido, a institucionalidade e capacidade de atuação da CIB (Fig. 7), o padrão predominante nas relações intergovernamentais, o papel da CIB na regionalização dos estados e a presença da regionalização na agenda das CIB (Quadro 9).

Considerando que todas as CIB foram criadas mais ou menos na mesma época, não parece ser o tempo de funcionamento em si que determina sua institucionalidade, mas sim elementos histórico-estruturais mais amplos (as características do arranjo federativo, o perfil dos municípios, a cultura política e as capacidades institucionais dos governos) e a própria trajetória específica da CIB no estado. (MACHADO et al., 2011, p.167). 
Na Região Concentrada, em todos os estados, a institucionalidade das CIB foi classificada como avançada e sua capacidade de atuação elevada (com exceção de um estado). Já na Amazônia, no Nordeste e no Centro-Oeste predominou a situação de institucionalidade intermediária das CIB. Destaca-se que a Amazônia e o Nordeste abrigam os estados cuja institucionalidade das CIB foi classificada como incipiente no momento da pesquisa, apesar dessas comissões funcionarem há cerca de quinze anos. Essas regiões também concentram os casos de baixa capacidade de atuação das CIB. No Centro-Oeste, as CIB apresentaram capacidades diferenciadas de atuação - baixa, intermediária e avançada.

\section{Figura 6 - Institucionalidade e capacidade de atuação da Comissão} Intergestores Bipartite, por estados- Brasil, 2007- 2010.

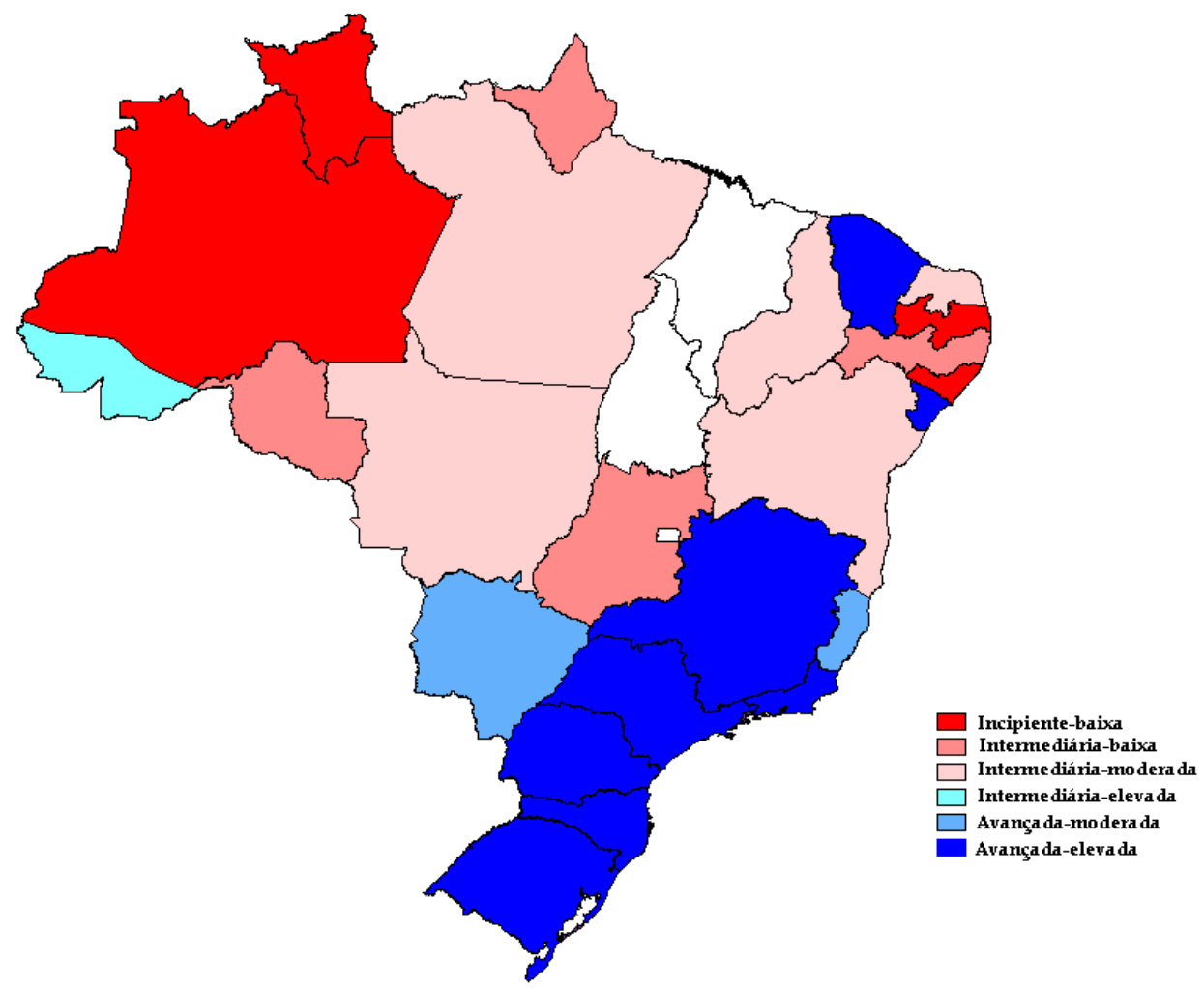

Fonte: Viana \& Lima (2011, p.215)

Na Amazônia, no âmbito das CIB, observa-se uma diversidade dos tipos de relações intergovernamentais, destacando-se que a região abriga os estados onde essas relações foram classificadas como restritivas e situações que impõem maiores dificuldades à coordenação federativa da política de saúde. O papel da CIB na regionalização do SUS nos estados é orientador/facilitador e a presença dessa 
temática na agenda das Comissões é fraca em dois terços dos estados e moderada nos demais.

No Nordeste, os tipos de relações intergovernamentais estabelecidos no âmbito das CIBs também impõem dificuldades à coordenação federativa da política de saúde. $O$ papel da $\mathrm{CIB}$ na regionalização foi predominantemente orientador/facilitador e consolidador, sendo classificado como indutor em dois estados. A presença da temática da regionalização na agenda das CIB foi fraca em $50 \%$ dos estados e elevada nos outros $50 \%$.

No Centro-Oeste, no âmbito das CIB, predominam as relações intergovernamentais cooperativas e interativas. Com exceção de um estado, o papel da CIB na regionalização foi classificado como indutor e consolidador, com elevada presença desse tema na agenda das Comissões.

Na Região Concentrada, as relações intergovernamentais são cooperativas e interativas, com exceção de um estado. $\mathrm{O}$ papel das CIB na regionalização foi consolidador, em alguns casos orientador/facilitador e, em outros, indutor desse processo nos estados. A presença da regionalização na agenda das CIB variou de moderada à elevada, relacionando-se diretamente com o papel da Comissão nesse processo (orientador/facilitador - moderada; indutor - elevada). 


\section{Quadro 9 - Padrão predominante nas relações intergovernamentais no âmbito da Comissão Intergestores Bipartite, seu papel na regionalização e presença deste tema na agenda da CIB, segundo os "quatro Brasis" (Brasil, 2007 a 2009)}

\begin{tabular}{|c|c|c|c|}
\hline & $\begin{array}{c}\text { Processo político/ } \\
\text { Relações intergovernamentais }\end{array}$ & $\begin{array}{l}\text { Papel da CIB na } \\
\text { regionalização }\end{array}$ & $\begin{array}{c}\text { Presença da regionalização na } \\
\text { agenda da CIB }\end{array}$ \\
\hline \multicolumn{4}{|c|}{ AMAZÔNIA } \\
\hline $\mathbf{A C}$ & cooperativas e interativas & Orientador/facilitador & Moderada \\
\hline RO & $\begin{array}{l}\text { cooperativas-conflitivas e } \\
\text { formalistas }\end{array}$ & Orientador/facilitador & Moderada \\
\hline $\mathbf{A M}$ & $\begin{array}{c}\text { cooperativas-conflitivas e } \\
\text { restritas }\end{array}$ & Orientador/facilitador & Fraca \\
\hline $\mathbf{A P}$ & cooperativas e interativas & Orientador/facilitador & Fraca \\
\hline $\mathbf{R R}$ & $\begin{array}{c}\text { cooperativas-conflitivas e } \\
\text { restritas }\end{array}$ & Indefinido & Fraca \\
\hline PA & cooperativas e formalistas & Indefinido & Fraca \\
\hline \multicolumn{4}{|c|}{ NORDESTE } \\
\hline $\mathbf{C E}$ & cooperativas e interativas & $\begin{array}{c}\text { Indutor } \\
\text { Consolidador }\end{array}$ & Elevada \\
\hline SE & cooperativas e interativas & $\begin{array}{c}\text { Indutor } \\
\text { Consolidador } \\
\end{array}$ & Elevada \\
\hline PI & cooperativas e interativas & $\begin{array}{l}\text { Orientador/facilitador } \\
\text { Consolidador }\end{array}$ & Elevada \\
\hline $\mathbf{B A}$ & $\begin{array}{c}\text { cooperativas-conflitivas e } \\
\text { interativas }\end{array}$ & $\begin{array}{c}\text { Orientador/facilitador } \\
\text { Consolidador }\end{array}$ & Elevada \\
\hline $\mathbf{A L}$ & $\begin{array}{c}\text { cooperativas-conflitivas e } \\
\text { formalistas }\end{array}$ & Indefinido & Fraca \\
\hline $\mathbf{R N}$ & cooperativas e formalistas & $\begin{array}{c}\text { Orientador/facilitador } \\
\text { Consolidador }\end{array}$ & Fraca \\
\hline $\mathbf{P E}$ & conflitivas e formalistas & $\begin{array}{l}\text { Orientador/facilitador } \\
\text { Consolidador }\end{array}$ & Fraca \\
\hline PB & $\begin{array}{l}\text { cooperativas-conflitivas e } \\
\text { formalistas }\end{array}$ & Indefinido & Fraca \\
\hline \multicolumn{4}{|c|}{ CEnTRO-OESTE } \\
\hline MS & cooperativas e interativas & $\begin{array}{c}\text { Indutor } \\
\text { Consolidador }\end{array}$ & Elevada \\
\hline MT & cooperativas e interativas & $\begin{array}{c}\text { Indutor } \\
\text { Consolidador } \\
\end{array}$ & Elevada \\
\hline GO & cooperativas e formalistas & Indefinido & Fraca \\
\hline \multicolumn{4}{|c|}{ REGIÃo CONCENTRADA } \\
\hline MG & cooperativas e interativas & $\begin{array}{c}\text { Indutor } \\
\text { Consolidador } \\
\end{array}$ & Elevada \\
\hline PR & cooperativas e interativas & $\begin{array}{c}\text { Indutor } \\
\text { Consolidador }\end{array}$ & Elevada \\
\hline RS & cooperativas e interativas & $\begin{array}{c}\text { Indutor } \\
\text { Consolidador }\end{array}$ & Elevada \\
\hline SP & cooperativas e interativas & $\begin{array}{c}\text { Indutor } \\
\text { Consolidador }\end{array}$ & Elevada \\
\hline RJ & cooperativas e interativas & $\begin{array}{l}\text { Orientador/facilitador } \\
\text { Consolidador }\end{array}$ & Moderada \\
\hline SC & cooperativas e interativas & $\begin{array}{l}\text { Orientador/facilitador } \\
\text { Consolidador }\end{array}$ & Moderada \\
\hline ES & cooperativas e formalistas & $\begin{array}{c}\text { Orientador/facilitador } \\
\text { Consolidador }\end{array}$ & Moderada \\
\hline
\end{tabular}

Fonte: adaptado de Viana \& Lima (2011) 
A questão do financiamento em saúde como condicionante indireto da regionalização do SUS nos estados foi tratada, no âmbito da pesquisa por Levi \& Scatena (2011), através da análise dos gastos em saúde da União, apontando algumas tendências regionais, e da identificação de padrões de despesa em saúde nos estados e conjunto de municípios de cada unidade da federação, considerando o período de 2002 a 2008.

De acordo com os autores, no período analisado, o aumento dos recursos destinados ao financiamento do SUS pela União, estados e município foi em média próximo a $10 \%$ ao ano. O crescimento foi mais evidente nos estados $(92 \%$ em termos reais) e municípios (80\%), em relação às despesas da União $(31,2 \%)$. Verificou-se a tendência de redução proporcional da participação da União no financiamento do sistema e a crescente importância da participação de estados e municípios no cofinanciamento do setor. Esses dados refletem as adequações dos gastos em relação às propostas da Emenda Constitucional 29, ao crescimento do Produto Interno Bruto - PIB e das receitas de impostos e contribuições.

Do ponto de vista da distribuição regional do gasto federal em saúde (Fundo Nacional de Saúde - FNS), entre 2002 e 2008, Levi \& Scatena (2011) agregaram os estados em cinco grupos conforme o padrão de concentração e tendência de crescimento das despesas do FNS (Tabela 4).

\section{Tabela 4 - Distribuição da despesa regionalizada do Fundo Nacional de Saúde} por grupos de UFs beneficiadas (em percentual do total) - 2002/2008

\begin{tabular}{|c|c|c|c|c|c|c|c|c|}
\hline grupos de UF & 2002 & 2003 & 2004 & 2005 & 2006 & 2007 & 2008 & $\begin{array}{c}\text { variação } \\
2002-2008\end{array}$ \\
\hline SP, RJ, MG, RS, BA, PR & $64,6 \%$ & $63,6 \%$ & $63,2 \%$ & $62,3 \%$ & $62,2 \%$ & $61,8 \%$ & $60,8 \%$ & $-5,9 \%$ \\
\hline PE, CE, SC, MA, PA, GO, PB & $21,5 \%$ & $21,7 \%$ & $22,0 \%$ & $22,4 \%$ & $22,4 \%$ & $22,7 \%$ & $23,3 \%$ & $8,3 \%$ \\
\hline ES, PI, RN, AL, MT, AM, MS & $10,0 \%$ & $10,5 \%$ & $10,6 \%$ & $10,9 \%$ & $11,0 \%$ & $11,1 \%$ & $11,4 \%$ & $13,9 \%$ \\
\hline DF, SE, TO, RO, AC, AP, RR & $3,9 \%$ & $4,2 \%$ & $4,2 \%$ & $4,4 \%$ & $4,4 \%$ & $4,4 \%$ & $4,6 \%$ & $15,8 \%$ \\
\hline Total (R\$ milhões/dez-2009 - IPCA) & $26.978,1$ & $29.904,7$ & $29.998,8$ & $30.410,4$ & $31.712,1$ & $35.100,1$ & $37.398,2$ & $38,6 \%$ \\
\hline$\%$ da despesa total do FNS & $72,3 \%$ & $72,7 \%$ & $71,2 \%$ & $70,2 \%$ & $72,8 \%$ & $76,0 \%$ & $76,3 \%$ & $5,5 \%$ \\
\hline
\end{tabular}

Fonte: Tesouro Nacional - SIAFI (SigaBrasil). Levi \& Scatena (2011, p.95).

Os autores observaram que apesar de a despesa do Fundo manter-se fortemente concentrada nos estados do primeiro grupo (maior parte deles localizados na Região Concentrada), ao longo do período, houve uma tendência de desconcentração regional para outros estados (localizados na Amazônia, Nordeste e 
Centro-Oeste, com exceção do Espírito Santo): o grupo de UFs que recebia a menor fatia do total do gasto regionalizado do Fundo - DF, SE, TO, RO, AC, AM e RR -, foi o que mais ganhou espaço em termos relativos $(15,8 \%)$, seguido pelo grupo que responde pela segunda menor fatia global do gasto regionalizado - ES, PI, RN, AL, MT, MS e AM.

Do ponto de vista dos indicadores de gasto em saúde por habitante, realizados pelos estados e municípios ${ }^{124}$ entre 2002 e 2008, Levi \& Scatena (2011) observaram um aumento considerável dos gastos com recursos próprios de estados e municípios em todas as regiões do país. Destacaram: (i) as regiões Centro-Oeste e Sul pela tendência de elevação dos gastos estaduais, e as regiões Norte e Centro-Oeste pela magnitude desses gastos (Gráfico 5); e (ii) as regiões Sul e Sudeste pela magnitude dos gastos municipais em saúde com recursos próprios, e as regiões Nordeste, Norte e Centro-Oeste pelas maiores elevações desses gastos (Gráfico 6).

\section{Gráfico 5 - Despesas dos estados em saúde com recursos próprios, por habitante, segundo a região - 2002/2008 (em R\$ de dezembro de 2009 - IPCA/IBGE)}

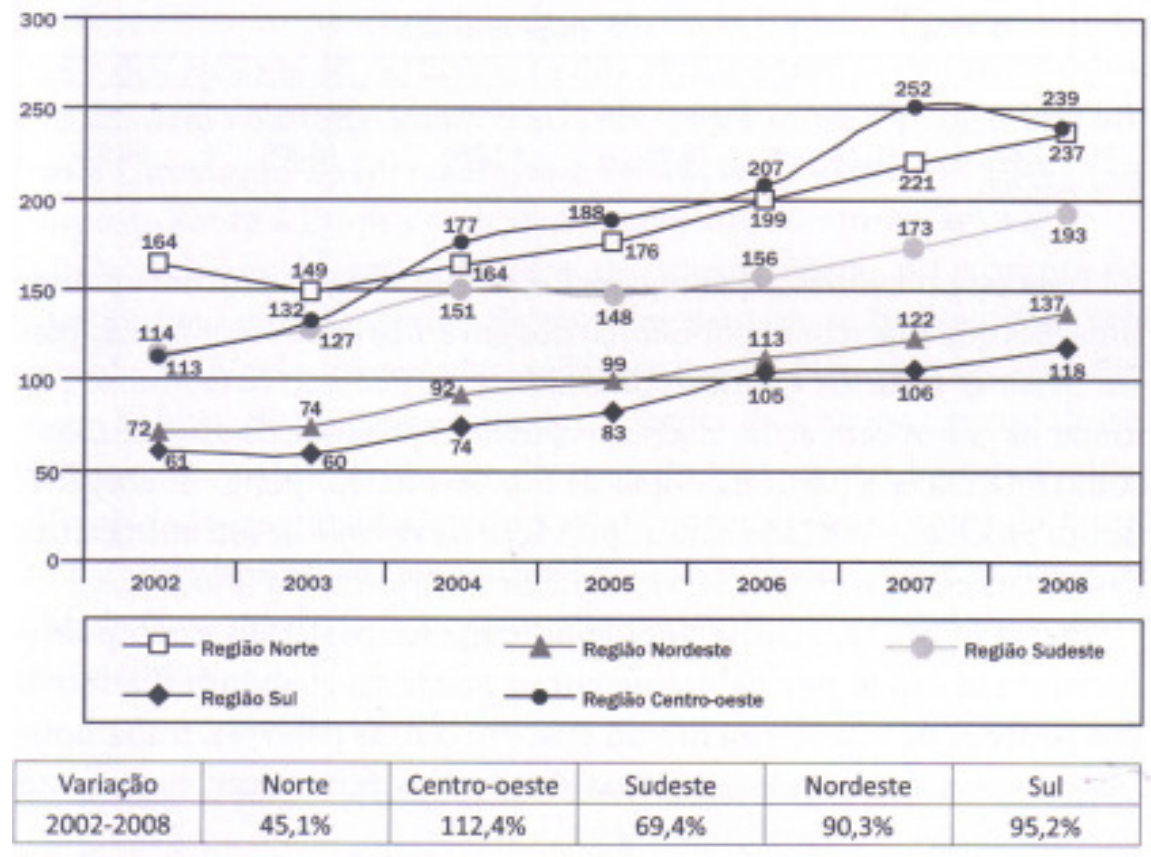

Fonte: Siops, IBGE. Levi \& Scatena (2011, p.99).

\footnotetext{
${ }^{124}$ Elementos de natureza fiscal que atuam como condicionantes dos gastos totais em saúde dos estados e municípios: capacidade de arrecadação própria, participação no bolo tributário da federação, critérios de partilha dos recursos do Fundo de Participação dos Estados e do Fundo de Participação dos Municípios (LEVI \& SCATENA, 2011).
} 


\section{Gráfico 6 - Despesas dos municípios em saúde com recursos próprios, por habitante, segundo a região - 2002/2008 (em R\$ de dezembro de 2009 - IPCA/IBGE)}

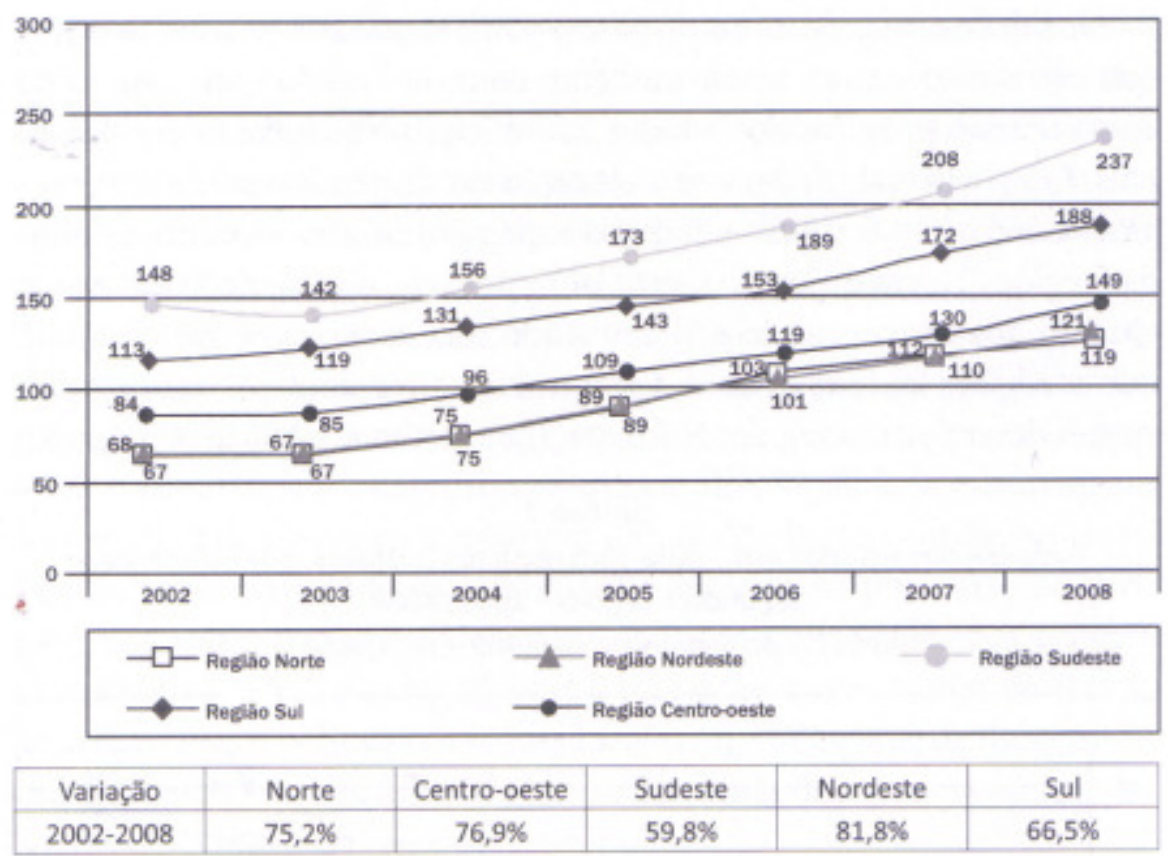

Fonte: Siops, IBGE. Levi \& Scatena (2011, p.100).

De acordo com os autores, as situações de gasto elevado resultam principalmente dos recursos próprios dos governos. Na maior parte dos casos que apresentaram gastos baixos também registra relativamente as mais altas taxas de transferência do SUS. De qualquer forma, a distribuição dos recursos da União tem um papel importante no sentido de reduzir as desigualdades regionais em relação aos gastos por habitante. Ao mesmo tempo, os gastos com recursos próprios dos estados e dos municípios cresceram num ritmo bem superior aos da União, no período analisado.

A capacidade dos gastos em saúde por parte dos municípios, mas, sobretudo, dos estados, indica que: (i) o fortalecimento do papel da esfera estadual na condução do planejamento regional do SUS veio acompanhado pelo ganho em termos dos recursos financeiros disponíveis, favorecendo o processo nos estados que concentram esses recursos e onde a institucionalidade da regionalização tende a ser mais avançada; e (ii) o crescimento da capacidade de gastos em saúde de estados e municípios, seja por meio dos recursos próprios ou das transferências da União, 
confere ainda mais importância à negociação intergovernamental ${ }^{125}$ sobre a distribuição regional dos recursos, demandando uma governança mais coordenada e cooperativa da regionalização do SUS.

Apresenta-se, a seguir, uma discussão dos resultados por região procurandose identificar especificidades e condicionantes do processo de regionalização do SUS compartilhados pelos estados no âmbito de cada situação geográfica.

\subsection{Amazônia: contextos menos favoráveis, institucionalidade incipiente e intermediária da regionalização do SUS}

A Amazônia se caracteriza pela rarefação e descontinuidade da urbanização, com baixa densidade demográfica e concentração populacional e das infraestruturas urbanas, atividades produtivas e investimentos nas capitais e polos regionais. As migrações populacionais constituem um elemento significativo para a dinâmica da região, e pode-se verificar, por exemplo, que alguns estados apresentam porcentagem de população não natural bastante importante.

A modernização seletiva na região provocou enorme mobilidade populacional inter e intrarregional e não resultou necessariamente em melhorias da infraestrutura urbana, incluindo aqui os serviços de saúde.

Os projetos de desenvolvimento regional, empreendidos pelo Estado brasileiro, ocasionaram em investimentos voltados para grandes projetos produtivos e infraestruturais, pouco contribuíram para mudanças nos padrões de desigualdades territoriais. De acordo com as entrevistas realizadas, há percepção de certo isolamento político dos estados da região em relação à participação destes na definição dos projetos nacionais e regionais de desenvolvimento.

A Amazônia apresenta grandes desigualdades internas e em relação às outras regiões do país quanto à capacidade instalada e aos investimentos públicos e privados em saúde, que se concentram nas capitais e em alguns polos regionais no interior dos estados, resultando em extensos vazios assistenciais.

${ }^{125}$ A região de saúde não constitui uma unidade de execução orçamentária em si. 
A descontinuidade urbana somada à baixa densidade populacional, ao baixo dinamismo econômico na maior parte do interior dos estados, à imensa extensão territorial e à precariedade da fluidez (redes de transporte e comunicação) dificultam a expansão do sistema de saúde (com baixa atração de profissionais e investimentos públicos e privados em equipamentos e serviços), o estabelecimento de fluxos intermunicipais de saúde e a própria conformação regional do SUS. Na maior parte dos estados se verifica um alto grau de isolamento geográfico de certos municípios, dada a raridade e precariedade das redes de transporte e comunicação, dificultando fluxos assistenciais intermunicipais da população e a própria participação dos gestores nas comissões intergestores do SUS.

Outros aspectos tornam ainda mais complexa a universalização da saúde ainda na região. Dentre eles, destacam-se: a grande diversidade do perfil socioeconômico e cultural da população (presença de reservas indígenas; população ribeirinha; população migrante); a ocupação desigual, com áreas de ocupação mais antiga e outras muito recentes, marcadas pelo rápido crescimento populacional e investimentos de grande porte (ligados, em geral, aos projetos de infraestrutura e mineração, que atraem um grande contingente de trabalhadores para se instalarem em municípios de pequeno e médio porte); e a extensa faixa de fronteira internacional, sob a proteção militar.

Na Amazônia, o processo de regionalização era muito incipiente na época de realização da pesquisa e encontra dificuldades estruturais e político-institucionais importantes.

A concentração econômica e de serviços de saúde nas capitais e determinados polos regionais e a baixa capacidade da gestão e oferta de serviços nos municípios do interior (mesmo de atenção básica), faz com que os estados sejam os protagonistas da gestão e prestação de serviços e fragiliza a maior parte dos municípios (em termos econômicos, institucionais, políticos).

Os estados e municípios enfrentaram (e ainda enfrentam) grandes dificuldades quanto ao processo de descentralização na saúde, dada a precária capacidade técnica, financeira e política dos entes municipais de promoverem a gestão, o financiamento e o planejamento em saúde. A maior parte dos municípios é altamente dependente do governo federal e estadual para efetivarem as políticas e 
programas de saúde. A falta de uma herança e capacidade técnica de planejamento territorial e setorial (incluindo a saúde) nos estados da Amazônia se agrava naqueles constituídos recentemente - os antigos territórios (Rondônia, que se tornou estado em 1982, Roraima e Amapá, que se tornaram estados somente com a Constituição Federal de 1988).

As dificuldades de planejamento, regulação e financiamento das políticas de saúde, agravadas pela fragilidade do processo de descentralização, pela insuficiência de recursos tecnológicos e humanos, pelas desigualdades territoriais na oferta de ações e serviços de saúde e pela raridade e fragmentação da rede urbana na região, dificulta a formulação e implementação das estratégias de regionalização.

Existem escassas e precárias experiências de regionalização em saúde anteriores ao Pacto pela Saúde, que confirmam um contexto histórico-estrutural desfavorável para o processo atual nos estados da Amazônia.

Os estados do Acre, Amazonas e Roraima não conheceram nenhum processo de regionalização da saúde anterior ao Pacto pela Saúde. No caso do Amazonas, existia apenas uma tentativa de tratar separadamente a capital e o interior, com subsecretarias estaduais separadas. No estado do Acre, apesar do processo de regionalização (regiões administrativas) ser antigo e vincular-se à história de constituição do território acreano e à dinâmica territorial atual, não há experiências de regionalização na saúde.

Já os estados do Amapá, Rondônia e Pará tiveram experiências anteriores de regionalização da saúde. No Amapá, a regionalização efetivada anteriormente assumiu um caráter predominantemente administrativo. O mesmo ocorreu no estado de Rondônia, com a definição de dois polos regionais de saúde e a conformação de instâncias regionais de planejamento e gestão, ainda com insuficiente capacidade gerencial, sem romper com a condição da secretaria de estado ser a grande coordenadora, planejadora e provedora da saúde. O estado do Pará possui a experiência mais antiga de regionalização em saúde. Desde a década de 1960, conta com treze Coordenadorias Regionais Administrativas da Saúde - CRS (que mantém correspondência com a divisão político-administrativa do governo estadual). Entretanto, ao longo dos anos, promoveu iniciativas de regionalização da saúde burocráticas e restritas às ações administrativas das CRS, que não romperam com a 
tradicional centralização de poder por parte do governo estadual e a concentração de serviços na capital, com escassez de oferta de saúde nas demais regiões.

O contexto político-institucional também é desfavorável para a regionalização do SUS nos estados da Amazônia e se relaciona diretamente com as dificuldades técnicas, políticas e financeiras da descentralização e articulação intergovernamental no âmbito da política de saúde nos estados. As políticas e os investimentos em saúde se efetivam com forte condução e coordenação das secretarias estaduais de saúde, que também apresentam dificuldades técnicas e financeiras, e forte indução pelo governo federal. A baixa capacidade técnica e financeira da maioria dos municípios resulta em baixa autonomia política e limitações para o processo de descentralização e regionalização da saúde.

Os Conselhos de Secretários Municipais de Saúde aparecem como principais articuladores entre estado e municípios, sobretudo, quando as Comissões Intergestores Bipartite exercem um papel menos protagonista, ou mesmo não são reconhecidas como espaço importante de negociação intergovernamental (caso de Roraima). As restrições nas relações entre os gestores da saúde, no âmbito das CIB, pareceram estar relacionadas a variáveis histórico-estruturais e político-institucionais (longas distâncias, dificuldades de deslocamento de gestores, limitações de capacidade institucional e situações de instabilidade ou conflito político) (Machado et al., 2011). As dificuldades em consolidar os espaços de negociação intergovernamental se aprofundam quando existem conflitos entre as secretarias estaduais e os conselhos municipais de saúde. Ao mesmo tempo, as dificuldades de deslocamentos dos gestores municipais limitam sua articulação através dos conselhos municipais, com prejuízo para o fortalecimento de sua representatividade regional (a exemplo do Acre). A escassez de experiências anteriores de regionalização da saúde dificultou a implantação dos Colegiados de Gestão Regional e o fortalecimento das instâncias regionais de gestão dos estados.

Essas questões repercutem nas tendências mais ou menos favoráveis do contexto conjuntural para o processo de regionalização em curso nos estados. Na Amazônia, apesar da influência da política nacional (Pacto pela Saúde) no desencadeamento do processo dos estados e, em alguns casos, do alinhamento político com o governo federal, não se verificou a priorização da regionalização na 
agenda dos estados e das secretarias estaduais de saúde, com exceção do Acre. No caso do Amazonas e do Pará, houve maior reconhecimento da relevância da regionalização por parte dos membros dos conselhos de secretários municipais de saúde.

Em geral, o perfil técnico-político dos responsáveis pela política de saúde nos estados nem sempre está ligado à área da saúde, com pouca tradição de gestão do SUS. Isso também contribui para as dificuldades de construção de instrumentos de planejamento e para a falta de memória e informações desse processo. Observa-se ainda a grande influência das questões político-partidárias no planejamento. Esses fatores contribuem para a baixa capacidade dos dirigentes estaduais e municipais para fortalecer e efetivar o processo de regionalização.

Apenas no estado do Acre foi possível identificar um contexto conjuntural mais favorável. Nesse sentido, destaca-se o alinhamento político entre os partidos da Presidência da República e dos governos do estado e da capital, o que favorece a entrada de novos recursos e investimentos federais na saúde e em outras áreas. Ao mesmo tempo, a regionalização ocupa um papel central na agenda do governo estadual e do conselho dos secretários municipais de saúde, e está vinculada à ampliação dos investimentos em serviços e equipamentos de saúde nos municípios e regiões. O perfil técnico e político dos responsáveis pela regionalização designam boa capacidade técnica e política de atuação e contribuem para a efetivação desse processo no estado.

Na Amazônia, observa-se uma diversidade de ideologias vinculadas ao processo de regionalização nos estados, com predomínio da equidade e gerencial. A ideologia da equidade se expressa pela preocupação com a diminuição das desigualdades e melhoria das condições de saúde da população, com a ampliação da capacidade instalada e do acesso no interior dos estados, para garantir a integralidade em todos os níveis de assistência, e com o fortalecimento da atenção básica nos municípios, dada a precariedade dos serviços e infraestruturas na maior parte deles. A ideologia democrática-participativa se caracteriza pela busca do maior protagonismo dos municípios na constituição das redes de saúde e do próprio processo de regionalização, assim como, pela necessidade de maior interação e cooperação intergovernamental na resolução dos problemas de saúde. A ideologia 
gerencial vincula-se à preocupação com a criação e o fortalecimento das estruturas regionais estaduais e das Comissões Intergestores Regionais, com a melhoria da qualidade da gestão e do planejamento, focando o papel do estado como coordenador, planejador e investidor regional do SUS, e com a melhoria do processo de descentralização política. A ideologia desenvolvimentista relaciona-se, ainda que de forma incipiente, com investimentos nacionais ou internacionais em políticas públicas voltadas para o desenvolvimento econômico e social dos estados (vinculase, de maneira moderada, com políticas mais amplas de desenvolvimento regional no estado Pará) ou de parte de suas regiões (Alto Solimões, no Amazonas).

A atuação das secretarias estaduais de saúde é preponderante na condução do processo de regionalização, e conta com o apoio do gestor federal, em alguns estados, e com o apoio dos Conselhos de Secretários Municipais de Saúde. Chama atenção a baixa participação das instâncias regionais das secretarias estaduais de saúde. Os prestadores privados (hospitais filantrópicos) não aparecem como atores relevantes desse processo, com exceção dos estados de Rondônia e do Pará onde o setor privado parece interferir mais fortemente no atual processo de regionalização, como uma força contrária à desconcentração dos serviços pelo interior dos estados, sobretudo, para áreas mais carentes. As ONGs e a Funai também não apresentaram participação relevante na discussão da regionalização dos estados da Amazônia, mas no Pará, no momento da realização da pesquisa, existia uma iniciativa inovadora, em fase inicial, de planejamento e regulação, envolvendo a participação de líderes indígenas.

O papel da CIB na regionalização do SUS nos estados é orientador/facilitador e a presença dessa temática na agenda das Comissões é fraca em dois terços dos estados e moderada nos demais. Os Colegiados de Gestão Regional constituídos no período analisado não exerciam ainda força técnica e política no processo de regionalização.

As estratégias da regionalização da saúde são variadas, sendo as principais: a criação, revisão do papel e o fortalecimento das instâncias regionais de gestão das secretarias estaduais e de negociação intergovernamentais; a revisão e/ou criação dos instrumentos de planejamento e regulação; a qualificação dos técnicos estaduais e municipais em planejamento e regulação; e a ampliação de recursos financeiros para 
saúde (incentivos financeiros e investimentos); construção de hospitais nos polos urbanos regionais. Uma série de instrumentos subsidia o processo de regionalização nos estados da Amazônia. Destacam-se: portarias federais; planos e programações (incluindo, em alguns casos, o Plano plurianual do estado - PPA); termos de compromisso de gestão; resoluções da CIB; contratualização; regulação e apoio logístico aos municípios; e diagnóstico das capacidades municipais para efetivar a regionalização.

Os principais objetos da regionalização no Norte são a organização de redes e fluxos, a ampliação da capacidade instalada (oferta) e a definição de regiões de saúde. A organização de redes e fluxos aparece como objeto principal desse processo, dada a complexidade política e geográfica para promover a desconcentração dos serviços para o interior dos estados, a integração das ações e serviços do SUS e o estabelecimento de fluxos assistenciais intermunicipais, com sistema de referência e contra-referência mais efetivo e diagnóstico sobre a infraestrutura de transporte e comunicação disponível para integração dos serviços e fluxos assistenciais. A estruturação de redes e fluxos é tida como importante estratégia para diminuição das desigualdades e ampliação do acesso e promete ser mais efetiva nos estados onde a rede urbana possui maior número de polos regionais conectados aos outros municípios por meio das redes de transporte e comunicação (caso do Pará e de Rondônia). No estado do Acre, o desenho regional da saúde seguiu as regiões administrativas por conta da existência dos polos urbanos, considerando-se a necessidade de estruturação de redes e fluxos a partir dos critérios de acesso geográfico e perfil epidemiológico da população. Entretanto, não se verifica maiores avanços em relação à formulação de um projeto de regulação mais abrangente.

No caso de Rondônia, o desenvolvimento recente (extrativismo, agronegócio e geração de energia) tem gerado investimentos crescentes que se revertem em vultosos recursos para o estado (e para a saúde), resultando como um dos objetivos da regionalização a ampliação da capacidade instalada através de investimentos em construções e equipamentos, da ampliação de programas e do credenciamento de serviços. 
Na Amazônia, o peso da tendência desfavorável dos contextos históricoestrutural, político-institucional e conjuntural dos estados e as características que marcam a situação geográfica macrorregional acarretam numa institucionalidade da regionalização do SUS que varia entre incipiente e intermediária. Apesar de todas as dificuldades técnicas, territoriais e políticas, a governança, quando definida, tende a seguir um padrão mais cooperativo e coordenado, com destaque para o protagonismo das secretarias estaduais e o importante papel exercido pelos conselhos municipais de saúde. Como consequência, predominam os impactos e inovações institucionais embrionários ou mesmo a ausência de tais impactos no processo de regionalização.

No momento de realização da pesquisa (2007-2009), os estados do Amazonas, Acre e Roraima ainda não haviam institucionalizado suas regiões de saúde e os respectivos CGRs.

Nos estados onde a institucionalidade da regionalização foi classificada como incipiente (AM, RR, AP), a redefinição das regiões de saúde não havia sido iniciada ou ainda estava em andamento e focava principalmente a revisão do Plano Diretor de Regionalização. Dinâmicas particulares dos estados, como a existência de fronteiras internacionais ou reservas indígenas, não haviam sido formalizadas no desenho regional. Os Colegiados de Gestão Regional estavam em processo de implantação.

Nos estados onde a institucionalidade da regionalização foi classificada como intermediária (PA, RO, AC), nota-se que a assistência hospitalar regionalizada é o principal elemento da definição do desenho das regiões de saúde. O foco da regionalização é a garantia de assistência aos municípios e o fortalecimento de estruturas regionais, a partir da regulação e do planejamento dessa assistência. Entretanto, não se identificavam ainda maiores avanços em relação à capacidade de regulação e de planejamento dos municípios e do estado, assim como, em relação à melhor definição dos papéis das instâncias regionais.

Em relação à governança da regionalização, nos estados onde não foi possível definir um padrão (AM, RR, PA), nota-se que os debates foram conduzidos pelas secretarias estaduais de saúde, com grande dificuldade de interação intergovernamental e de inclusão de outros atores de relevância na região.

No estado onde a governança foi definida como coordenada-conflitiva (RO), as instâncias regionais da secretaria estadual de saúde eram as únicas estruturas 
regionalizadas e os Colegiados de Gestão Regional estavam em implantação. A Comissão Intergestores Bipartite ainda estava se consolidando como espaço de negociação intergovernamental e de indução da regionalização. Existiam relações conflituosas entre a secretaria estadual de saúde e o conselho de secretários municipais de saúde. Além disso, o setor privado tem forte presença no estado e interfere indiretamente na regionalização.

Nos estados onde a governança foi definida como cooperativa (AP, AC), o planejamento e a regulação são conduzidos pela secretaria estadual de saúde, com fragilidade, pois os instrumentos não foram atualizados ou estavam em processo de revisão. A regionalização é conduzida pela secretaria estadual de saúde e articulado pelo conselho de secretários municipais de saúde. Não havia diversidade de atores e instâncias com peso na regionalização. Os mecanismos de coordenação das ações na regionalização são tradicionais e formalistas e as relações intergovernamentais são crescentemente cooperativas, ainda que não sejam identificadas parcerias formalizadas por instrumentos legais.

Os impactos e inovações institucionais relacionados ao processo de regionalização em curso são ausentes em alguns estados (AM, AP, RR), embrionários em outros (PA, RO) e incremental em apenas um estado (AC), onde houve mudanças na gestão da secretaria estadual de saúde, com ganho de participação dos municípios e melhoria na atenção à saúde.

\subsection{Nordeste: contextos mais $e$ menos favoráveis, institucionalidade incipiente a avançada da regionalização do SUS}

O Nordeste se caracteriza por uma ocupação antiga (urbana e produtiva) e pela difusão mais pontual e concentrada do desenvolvimento econômico na faixa litorânea (capitais) e polos regionais do interior, condicionada pelas estruturas históricas da modernização da região. Historicamente, a desigualdade e a concentração da riqueza e da propriedade demarcam e conformam as relações sociais e políticas nos estados. 
O Nordeste conheceu experiências importantes de regionalização que estiveram mais voltadas para a constituição de polos de desenvolvimento (industrial; extrativista; agropecuário) e não romperam como o padrão estrutural da desigualdade e de concentração da riqueza, da população, do trabalho, da urbanização e dos serviços nas capitais e poucas cidades do interior dos estados.

O Nordeste apresenta grandes desigualdades quanto à capacidade instalada e aos investimentos públicos e privados em saúde, que seguem o padrão regional de concentração nas capitais e em alguns polos do interior, resultando em vazios assistenciais. A baixa densidade populacional e da rede urbana somada ao baixo dinamismo econômico de grande parte dos municípios dificulta a expansão do sistema de saúde e a estruturação de redes regionalizadas.

Os estados do Nordeste enfrentam dificuldades em relação ao processo de descentralização política, que se expressam pelo grande número de municípios dependentes das capitais e dos governos estadual e federal, em termos de capacidade técnica e financeira para a execução das ações e programas da política de saúde. Muitos desses municípios também enfrentam dificuldades no exercício de sua autonomia em função das heranças oligárquicas da estrutura do poder político na região.

As desigualdades originadas pelo baixo dinamismo econômico do interior, com baixa densidade urbana, aliadas à fragilidade do processo de descentralização e das experiências de regionalização em saúde revelam um contexto históricoestrutural e político-institucional desfavorável para o atual processo de regionalização nos estados do Nordeste, com exceção de Sergipe, Ceará e Piauí.

Apesar das dificuldades elencadas, em todos os estados da região as experiências de regionalização administrativa e setorial da saúde são antigas (algumas originadas antes mesmo da criação do SUS), ligadas à história de formação e desenvolvimento econômico dos estados e de seus sistemas e políticas de saúde, com destaque para aquelas promovidas pelos estados da Bahia, do Rio Grande do Norte, do Ceará e de Sergipe.

O estado de Sergipe é o único que apresenta um contexto histórico-estrutural mais favorável. Isso se deve a dois motivos principais. Em primeiro lugar, o processo de conformação de regiões no estado é antigo e guarda correspondência com a 
história de desenvolvimento econômico e com os movimentos de ocupação do território. Este processo deu origem a municípios que agregam infraestrutura de serviços de abrangência microrregional. Em segundo lugar, o estado possui pequena dimensão territorial, o que implica em menores distâncias entre a capital e outros municípios, favorecendo o acesso da população aos serviços que estão concentrados na Região Metropolitana de Aracaju. Além disso, a população do estado também está concentrada nessa área. O estado é considerado uma macrorregião, subdividido microrregionais.

Sergipe, Ceará e Piauí se caracterizam por apresentarem contextos políticoinstitucional mais favoráveis ao processo de regionalização do SUS. Destaca-se: a importância do governo estadual na formulação e implantação de políticas de saúde, com baixo peso do setor privado na oferta de serviços (SE, CE); a valorização da pactuação intergovernamental através da organização e funcionamento da Comissão Intergestora Bipartite e dos Colegiados de Gestão Regional, que oferecem maior legitimidade aos técnicos estaduais e municipais e acentuam o caráter técnicopolítico das discussões (SE, CE); a amplitude do processo de regionalização em curso - ancorado em políticas de reforma sanitária e gerencial do estado, apoiadas no planejamento e investimentos em saúde (SE).

Destaca-se que o Ceará é precursor nas iniciativas de conformação regional da saúde, com forte presença de planejamento regional e estruturas regionais sólidas e com considerável autonomia. O estado conta com um conselho de secretários municipais forte técnica e politicamente, altamente estruturado e com efetiva participação na condução das políticas, além de instâncias regionais legitimadas e importantes na conformação da política de saúde (CIB Micrroregionais, atuais Comissões Intergestores Regionais - CIR).

O estado do Piauí, apesar de não ter tradição de planejamento em saúde e do enorme peso do setor privado na regulação da distribuição espacial da oferta dos serviços, nos últimos anos, conforme as entrevistas realizadas houve um fortalecimento do papel da secretaria estadual de saúde e de certos polos regionais na definição das políticas de saúde. O estado tem procurado fortalecer suas ações na regulação e no planejamento do SUS e contribuir para que os municípios construam uma visão regional do sistema de saúde. Destaca-se que o conselho de secretários 
municipais de saúde tem ampliado sua participação e representatividade regional, consolidando seu papel técnico e político nos fóruns de deliberação da política de saúde.

Apesar da tendência desfavorável dos contextos histórico-estrutural e político-institucional na maior parte dos estados do Nordeste, verifica-se uma tendência mais favorável em relação ao contexto conjuntural para o processo de regionalização do SUS. Apenas os estados de Alagoas, Paraíba e Rio Grande do Norte apresentaram uma indefinição quanto à tendência do contexto conjuntural.

Os contextos conjunturais favoráveis à regionalização se justificam, em primeiro lugar, pelo alinhamento político entre os partidos da Presidência da República e dos governos dos estados (incluindo, algumas vezes, o partido do governante da capital), que favorece a entrada de novos recursos e investimentos federais na saúde e em outras áreas. Em segundo lugar, pela prioridade da regionalização na agenda do estado e das secretarias estaduais de saúde, favorecida, em alguns casos, pelas experiências prévias e consolidadas de planejamento regional nos estados. Finalmente, em terceiro lugar, pelo perfil e trajetória dos atores políticos - que designam sua capacidade técnica e política de atuação - ligados à área da saúde, aos processos da Reforma Sanitária e à consolidação do SUS; ao histórico de participação na formulação da política de saúde nos estados, municípios e governo federal; e à formação técnica e de nível superior na área da saúde ou afins.

Nos estados da Bahia e de Pernambuco, onde os contextos histórico-estrutural e político-institucional se apresentaram como desfavoráveis e o conjuntural foi favorável, o alinhamento político com o governo federal associado à trajetória e perfil dos atores políticos representa uma força política e econômica importante para o enfrentamento dos outros aspectos desfavoráveis. Nesses estados, a regionalização é tida como prioridade para o governo e as secretarias estaduais de saúde.

Em relação à direcionalidade, o processo de regionalização nos estados do Nordeste é orientado por uma diversidade de ideologias - equidade, democráticaparticipativa, gerencial, desenvolvimentista e determinantes sociais em saúde -, com predominância das três primeiras. A ideologia da equidade se expressa pela preocupação com a melhoria das condições de saúde, com a ampliação da capacidade instalada e do acesso e garantia de integralidade da atenção à saúde, nas regiões mais 
carentes dos estados. A ideologia democrática-participativa se traduz pela valorização da ação cooperativa e solidária entre os gestores, na resolução de problemas de saúde, pelo fortalecimento das instâncias colegiadas de gestão e pactuação regional e pela ampliação da participação dos atores envolvidos na regionalização (institucionais e outros), sobretudo, dos municípios. A ideologia gerencial caracteriza-se pela preocupação em organizar redes e fluxos, aumentar a capacidade gerencial, planejadora e reguladora dos estados e municípios, formalizar a contratualização com prestadores, legalizar o processo de regionalização, modernizar a gestão de serviços, aumentar os investimentos regionais e melhorar a capacidade institucional dos estados para fortalecer a lógica pública na política de saúde. A ideologia desenvolvimentista relaciona-se à priorização da saúde pelo governo estadual e sua articulação com outras políticas de desenvolvimento econômico e social, voltadas para as regiões, com fortalecimento do enfoque regional no planejamento estatal (caso da Bahia e do Piauí). A ideologia dos determinantes sociais em saúde vincula-se às políticas sociais voltadas para a promoção da saúde.

Destaca-se que, no estado do Piauí, o momento de reformulação da regionalização com base nas diretrizes do Pacto pela Saúde coincidiu com a proposição e implementação dos territórios de desenvolvimento, definidos como referência para o planejamento regional das políticas públicas no estado (inclusive as de saúde) (Plano Plurianual). A orientação democrática-participativa relacionou-se à ampliação da participação dos atores envolvidos na regionalização (institucionais e outros) na elaboração dos planos territoriais de desenvolvimento, do PPA do estado e da política de saúde. A orientação desenvolvimentista estava vinculada à articulação de todas as políticas sociais e econômicas do governo estadual voltadas para os territórios de desenvolvimento.

Os objetos da regionalização nos estados do Nordeste são a organização de redes e fluxos, a ampliação da capacidade instalada (oferta) e a definição de regiões de saúde. A importância da "questão nordestina" nos planos nacionais de desenvolvimento, atualizada na última década, favoreceu o aumento dos investimentos produtivos e em infraestruturas, além dos investimentos em políticas sociais, incluindo as políticas de saúde. Nesse contexto, a ampliação da capacidade instalada aparece como um dos principais objetos da regionalização do SUS. 
Observa-se uma diversidade de atores que participam do processo de regionalização da saúde, com destaque para o protagonismo das secretarias estaduais de saúde e suas instâncias regionais de gestão. Os municípios também são muito participativos, assim como, os Conselhos de Secretários Municipais de Saúde. A atuação do governo federal se mostra menos relevante para a regionalização nos estados do Nordeste. Os Colegiados de Gestão Regional (atuais CIR) representam grande importância no processo de regionalização. Já as Comissões Intergestoras Bipartite nem sempre aparecem como atores relevantes desse processo, pois, em geral, os tipos de relações intergovernamentais estabelecidos no âmbito das CIBs impõem dificuldades à coordenação federativa da política de saúde.

Destaca-se a participação de atores da Assembleia Legislativa (caso de Sergipe) e das Universidades públicas em alguns estados. Os prestadores privados (filantrópicos e lucrativos) também aparecem como atores importantes da regionalização, ainda que sua participação seja indireta.

As principais estratégias da regionalização da saúde presentes nos estados do Nordeste são: a criação e/ou fortalecimento de instâncias de gestão regional das secretarias estaduais e de negociação intergovernamentais regionais; a revisão e/ou criação dos instrumentos de planejamento e regulação; a ampliação de recursos financeiros (incentivos financeiros e investimentos); e a ampliação da participação dos atores governamentais. Destacam-se os seguintes instrumentos que subsidiaram o processo mais recente de regionalização da saúde nos estados do Nordeste: leis estaduais; portarias federais; planos e programações (incluindo o PPA e Programas Estratégicos Estaduais); contratualização; capacitação; apoio técnico aos municípios; processos participativos; regulação; e lei dos consórcios intermunicipais.

Nos estados do Nordeste, há maior diversidade de situações em relação à institucionalidade, governança e impactos e inovações institucionais relacionados ao processo de regionalização do SUS. O peso da tendência desfavorável dos contextos histórico-estrutural, político-institucional e conjuntural dificulta a institucionalização do processo de regionalização nos estados, com exceção do Ceará e de Sergipe. Esses contextos também pesam na classificação da governança, ainda que tenha predominado o padrão mais cooperativo e coordenado nas relações intergovernamentais. $\mathrm{O}$ papel da CIB na regionalização foi predominantemente 
orientador/facilitador e consolidador, sendo classificado como indutor em dois estados, justamente no Ceará e em Sergipe, onde os contextos foram mais favoráveis, a regionalização alcançou institucionalidade mais elevada e a governança foi coordenada e cooperativa. A presença da temática da regionalização na agenda das CIB foi fraca em 50\% dos estados e elevada nos outros 50\% (BA, CE, PI, SE).

Em relação aos impactos e inovações institucionais relacionados ao processo de regionalização nos estados, observou-se o predomínio daqueles caracterizados como incrementais. Contribuíram para isso a tradição do planejamento regional em saúde nos estados do Nordeste e a existência prévia de instâncias de gestão e planejamento regional das secretarias estaduais e, em alguns casos, de comissões intergestores regionais. O Nordeste abriga os dois únicos estados brasileiros analisados que apresentaram impactos e inovações institucionais radicais, são eles: Piauí e Sergipe.

Os estados de Alagoas e da Paraíba mostraram uma situação mais incipiente da institucionalidade da regionalização, apesar da prática antiga de planejamento regional. No caso de Alagoas, a regionalização está ligada à distribuição da oferta assistencial e, apesar do foco na ampliação do acesso, não enfatizou mudanças no desenho da estrutura assistencial existentes. Existem deficiências importantes na regulação, justificadas pela escassez de recursos para execução das ações, e os investimentos regionais na saúde realizados pela secretaria estadual estão relacionados aos programas estratégicos do governo estadual de ampliação da capacidade instalada, porém com baixa adaptação à realidade loco-regional. Já no caso da Paraíba, o processo de regionalização da saúde ocorreu em três momentos: primeiro, a regionalização atrelada à divisão administrativa da saúde; segundo, baseada em critérios convencionais para definição de regiões (contiguidade geográfica e capacidade instalada); e terceiro e mais recente, orientado pela flexibilidade na composição das regiões, visando atender às diferenças regionais e favorecer a ação cooperativa e solidária entre os gestores. Apesar dos avanços, as modificações no desenho das regiões resultaram em recortes que não coincidem mais com a divisão administrativa do estado, que serve de base para outras regionalizações setoriais, como educação e segurança pública. Isso dificulta a relação das políticas regionais de saúde com outras políticas de desenvolvimento regional. Ao mesmo 
tempo, a mudança no desenho das regiões de saúde demandou uma reorganização e construção das instâncias de gestão e negociação intergovernamentais, que apresentavam, no momento da pesquisa, uma atuação incipiente. O papel da secretaria no financiamento regional é bastante incipiente, com poucos mecanismos instituídos. Embora reconhecidamente importante, a regionalização ainda não é uma prioridade na agenda principal da secretaria estadual de saúde. Em ambos os estados, a secretaria estadual de saúde é protagonista na condução do planejamento regional e da regulação, que é incipiente e enfrenta grandes deficiências.

Os estados da Bahia, de Pernambuco, Piauí e Rio Grande do Norte apresentam uma situação intermediária quanto à institucionalidade do processo recente de regionalização do SUS. Os fatores que contribuem para isso o fato de, em alguns casos, a regionalização ser antiga e ancorada nas estruturas administrativas da secretaria estadual de saúde; ou ser ancorada num desenho setorial, baseado em critérios tradicionais, mas ter como foco a reconfiguração dos poderes no âmbito regional (participação e negociação intergovernamental), no planejamento e na organização de redes para ampliação do acesso. A regionalização é prioridade na agenda estadual e, no caso da Bahia e do Piauí, se articula com outras políticas de desenvolvimento do governo estadual, com esforço de construção de um enfoque regional do planejamento governamental. Também pesa o fato das secretarias estaduais de saúde serem protagonista na condução do processo de regionalização, a partir da articulação com diferentes setores das políticas públicas (BA, PI) e da construção de uma parceria com o conselho de secretários municipais de saúde. Contudo, a atuação das secretarias estaduais de saúde era ainda incipiente no planejamento e na regulação das redes e fluxos assistenciais (exceção da Bahia). As instâncias colegiadas e de gestão regionais estavam implantadas, porém, com funcionamento variável entre nas regiões de saúde.As secretarias estaduais de saúde e o Ministério da Saúde exercem importante papel no financiamento regional do SUS, ainda que em alguns estados os investimentos ainda sejam incipientes.

Os estados do Ceará e Sergipe apresentaram institucionalidade avançada da regionalização da saúde. No Ceará, a regionalização da saúde é antiga e institucionalizada organizacional, técnica e politicamente. Também há tradição de descentralização política no estado. O desenho das regiões é próprio da saúde e passa 
por revisões sistemáticas, incorporando dinâmicas específicas do estado. Uma das estratégias do processo de regionalização é o fortalecimento das instâncias regionais existentes. As Coordenadorias regionais da secretaria de estado da saúde têm tradição na gestão regional e são fortalecidas. Os Colegiados de Gestão Regional (antigas CIBs Micro-regionais e atuais Comissões Intergestores Regionais - CIR) estão consolidados, legitimados e atuantes. O planejamento regional tem como foco a organização de redes assistenciais para ampliação do acesso e a consolidação dos espaços decisórios regionais. A regulação ocorre com base na contratualização e nas centrais de regulação implantadas (informadas pelos fluxos regionais). Tanto o planejamento regional quanto a regulação são conduzidos pela secretaria estadual de saúde em parceria com o conselho de secretários municipais de saúde - ambos fortes (técnica e politicamente) e atuantes. A regionalização da saúde está presente na agenda governamental, através de investimentos na ampliação da capacidade instalada e da qualificação dos quadros técnicos. No momento de realização da pesquisa, havia grande incentivo estadual para o cumprimento das metas do Pacto pela Saúde. O processo de regionalização indica relações intergovernamentais de padrão cooperativo com fluxos decisórios definidos. Contudo, há tensões importantes entre os municípios de pequeno e médio porte com os de grande porte, em especial com Fortaleza, no processo decisório (única região de saúde que ainda não assinou o Coap no estado do Ceará, pós-publicação do Decreto 7.508/11).

No estado de Sergipe, a regionalização também é antiga e o processo desencadeado pelas diretrizes do Pacto pela Saúde trouxeram mudanças incrementais em relação ao desenho das regiões. Este é setorial, com ênfase na organização microrregional da oferta de serviços de saúde. Verifica-se a forte presença e atuação da secretaria estadual de saúde na condução do processo, ocupando papel de destaque na agenda estadual, em articulação com o conselho de secretários municipais de saúde. A reforma sanitária e gerencial da secretaria estadual, iniciada em 2007, resultou em mudanças expressivas nas estruturas nas estruturas e no papel da secretaria, na organização do sistema estadual e na coordenação intergovernamental, caracterizando impactos e inovações institucionais radicais em Sergipe, decorrentes do processo de regionalização pós-Pacto pela Saúde. Nesse processo, foram implantados Colegiados Interfederativos Regionais (CIRs) (que se 
assemelhavam aos CGRs), cuja principal atribuição era definir aspectos da integração funcional e operativa dos serviços de saúde na região. Novos instrumentos foram criados, com destaque para o Mapa Sanitário, o Padrão de Integralidade da Assistência à Saúde no Estado de Sergipe e os Contratos de Ação Pública - CAP ${ }^{126}$ (que inspiraram os atuais Coaps na política nacional). O CAP definiu as responsabilidades dos municípios e do estado na prestação de serviços de saúde, bem como o seu financiamento, formalizando compromissos assumidos entre os gestores, incluindo as metas relativas aos indicadores do Pacto pela Saúde, consistindo em uma ampla estratégia de contratualização entre os gestores. O fortalecimento dos mecanismos de coordenação regional ocorreu por meio dos instrumentos legais (com participação do poder legislativo estadual) e operacionais e da regulação pública na prestação de serviços. Destaca-se que a regulação é feita com base na contratualização entre entes públicos e com prestadores privados, ainda que, no momento de realização da pesquisa, a regulação de fluxo não havia sido implantada. O contexto político (governo estadual) e econômico e o perfil dos atores envolvidos (historicamente ligados à área da saúde) também favoreceram os acordos e parcerias entre a secretaria estadual e o Conselho de Secretários Municipais de Saúde, e os investimentos expressivos na rede de serviços assistenciais do estado. Havia grande expectativa com a implantação dos Colegiados Interfederativos Regionais (atuais CIR), para o fortalecimento das relações intergovernamentais regionais. Estas eram cooperativas, sem conflitos importantes no âmbito regional.

Em relação à governança do processo de regionalização nos estados do Nordeste, observa-se que a indefinição de um padrão de governança (Bahia e Paraíba) decorre da atuação incipiente das instâncias de gestão regional, sem a consolidação de seus papéis no processo. Contribui para isso a fragilidade da atuação

\footnotetext{
126 “O Contrato de Ação Pública (CAP), um dos instrumentos preconizados pela reforma sanitária e gerencial de SE, deve ser assinado conjuntamente pelos Prefeitos e Secretários Municipais de Saúde dos 75 municípios do estado e pelo Governador e Secretário de Estado de Saúde. (...).Além de cláusulas gerais (compromissos comuns entre os entes relacionados aos direitos dos cidadãos e aos princípios do SUS), o CAP estabelece as responsabilidades de cada município na rede regionalizada e hierarquizada de serviços de saúde, a partir de diagnóstico e proposta detalhada de planejamento e programação nos diferentes campos de atenção e níveis de complexidade de assistência. Seu prazo de vigência é de 4 anos, sendo reavaliado a cada ano. Inclui, ainda, os prazos e critérios de avaliação, bem como as penalidades (suspensão dos incentivos estaduais) caso os acordos não sejam cumpridos". (Viana \& Lima [coord.]. Relatório Estadual de Sergipe. Avaliação nacional das Comissões Intergestores Bipartites (Cibs): as Cibs e os modelos de indução da regionalização no SUS, maio de 2010).
} 
do conselho de secretários municipais de saúde, no caso da Bahia. Chama a atenção a diversidade de atores envolvidos no processo de regionalização, com destaque para os prestadores privados e organizações profissionais médicas (BA). No estado da Paraíba, as relações intergovernamentais são cooperativas, havendo conflitos relativos à divergência de visões e interesses entre estado e conselho de secretários municipais de saúde - particularmente entre a gestão estadual e a gestão da capital. Percebe-se a fragilidade dos canais institucionalizados para debate e formação de consensos técnicos entre estado e municípios no âmbito da Comissão Intergestores Bipartite. Já no estado da Bahia, não há um padrão predominante nas relações intergovernamentais, existem dificuldades na coordenação regional e a Comissão Intergestores Bipartite exerce papel importante para a melhoria da coordenação.

No caso da governança coordenada-conflitiva (Pernambuco) e conflitiva (Alagoas), observa-se um desacordo entre a secretaria estadual de saúde e o conselho de secretários municipais de saúde quanto às estratégias de regionalização, sobretudo, quanto à condução unilateral ou mais centralizada pelo estado. As instâncias regionais de gestão estão sendo implantadas e há poucos mecanismos de coordenação das ações relacionadas à regionalização, com papel ainda restrito da Comissão Intergestores Bipartite. Observa-se também a forte influência do setor privado no processo de regionalização, por conta da dependência do SUS em relação à oferta privada (filantrópicos) e a tendência de concentração dos investimentos privados em serviços nas capitais e polos regionais.

A governança cooperativa (Piauí e Rio Grande do Norte) é caracterizada pela ausência de grandes conflitos no âmbito regional, ainda que haja grande assimetria técnica e política entre estado e municípios. As estruturas de coordenação regional encontravam-se, no momento da pesquisa, em processo de consolidação e definição de seus papéis (CIB-PI). Há forte expressão dos prestadores privados no processo de regionalização, pelos mesmos motivos apontados anteriormente para os estados de PE e AL.

A governança coordenada-cooperativa (Ceará e Sergipe) está relacionada aos fluxos decisórios definidos nas instâncias colegiadas, ainda que existam tensões entre os municípios, com fortalecimento dos mecanismos de coordenação por meio de instrumentos legais (SE), sem conflitos importantes no âmbito estadual. 
Quanto aos impactos e inovações institucionais decorrentes do processo de regionalização nos estados do Nordeste, destaca-se que foram embrionários (AL, PB) quando as mudanças principais recaíram apenas sobre o novo desenho regional e a implantação dos Colegiados de Gestão Regional. Foram incrementais (BA, CE, PE, RN) quando houve mudanças no papel da secretaria estadual de saúde, na coordenação intergovernamental e o reforço dos poderes municipais e das instâncias regionais. No caso do Ceará, aponta-se a melhoria na organização de redes de referência, o aumento da capacidade instalada e o incentivo para a inclusão de novos atores, como os consórcios intermunicipais. Por fim, os impactos e inovações institucionais foram radicais (PI, SE) quando houve mudanças expressivas nas estruturas e no papel da secretaria estadual de saúde, na organização do sistema estadual e na coordenação intergovernamental. Destaca-se, no caso do Piauí, que as mudanças no papel da secretaria estadual de saúde, voltadas para o planejamento regional, objetivavam o fortalecimento do SUS no estado e ganhos em termos de descentralização e desconcentração do sistema, associados também à agenda de desenvolvimento regional estadual (territórios do desenvolvimento). O caso de Sergipe foi mencionado anteriormente.

\subsection{Centro-Oeste: contextos mais favoráveis, institucionalidade intermediária e avançada da regionalização do SUS}

A Região Centro-Oeste representa um novo front de expansão rápida e crescente da agropecuária e da urbanização globalizadas. A partir da década de 1960, a construção de Brasília e a difusão da produção de soja e criação de gado ofereceram à região uma nova posição política e econômica nos rumos do desenvolvimento brasileiro. Isso se acentuou com a expansão do agronegócio de alta incorporação tecnológica (agricultura de precisão), a partir da década de 1990, aumentando a produção da soja e criação de gado. O estado do Mato Grosso do Sul lidera os investimentos e produção agropecuária no país. Essa expansão proporcionou a diversificação, modernização e o crescimento da economia agrícola e urbana, intensificando o processo de urbanização, constituição da rede urbana e polos regionais, crescimento populacional e densificação das redes de fluidez territorial. 
Esse processo atraiu muitos migrantes da Região Concentrada, sobretudo, dos estados do Sul, contribuindo para a densificação da rede urbana. Mas, nas áreas menos valorizadas pela modernização agropecuária e urbana, verifica-se uma baixa densidade populacional e urbana e um baixo dinamismo econômico de parte dos municípios. Mesmo no caso do Mato Grosso do Sul, estado relativamente novo, criado a partir da divisão do MT (1977-79), existem polos regionais urbanos mais antigos e outros mais recentes, resultando em diferentes padrões de desigualdades socioespaciais. No Centro-Oeste, a população se concentra nas capitais e polos regionais e é predominantemente urbana.

Apesar do desenvolvimento econômico acelerado, a região também enfrenta desigualdades territoriais quanto à capacidade instalada e aos investimentos públicos e privados em saúde, que se concentram nas capitais e em nos polos regionais no interior dos estados, resultando em alguns vazios assistenciais (sobretudo nas áreas menos populosas, urbanizadas e economicamente dinâmicas). As secretarias estaduais enfrentam dificuldades para promover a expansão do sistema nessas áreas.

O Centro-Oeste também enfrenta problemas no processo de descentralização política em relação a esses municípios de pequeno porte e baixo dinamismo econômico, que dependem do governo federal, estadual e das próprias capitais, em termos de capacidade técnica e financeira, para a execução das ações e programas da política de saúde. Mas, em geral, houve um fortalecimento do processo de descentralização política na região nos últimos vinte anos, impulsionado, dentre outros fatores, pelo crescimento do poder econômico e políticos dos estados. Pode-se afirmar que a migração de pessoas da Região Concentrada - estados com tradição de descentralização política e de planejamento - propicia condições favoráveis de conhecimento e atuação em saúde aos governos estaduais e municipais da região Centro-Oeste. Entretanto, essas migrações destinam-se, em grande parte, justamente aos municípios com maior dinamismo e diversificação econômica e não àqueles que mais necessitam deste suporte. Esta situação acaba reforçando a desigualdade na capacidade técnica e financeira para a execução da política de saúde na região.

A expansão do desenvolvimento econômico e a consolidação de importantes polos regionais associadas ao fortalecimento do processo de descentralização política e às experiências recentes de regionalização em saúde revelam um contexto 
histórico-estrutural e político-institucional favoráveis para o atual processo de regionalização nos estados.

Há experiências de regionalização administrativa e setorial da saúde nos estados do Mato Grosso, a partir de meados da década de 1980, e do Mato Grosso do Sul, a partir da década de 1990. Os antigos polos regionais e outros que emergiram com a modernização, e as regiões fronteiriça e pantaneira, serviram, até recentemente, para a divisão das regiões de saúde e administrativas.

Em ambos os estados o contexto político-institucional favorável se deve a efetiva descentralização da política de saúde, à forte indução da regionalização por parte das secretarias estaduais, com continuidade desse processo, desde sua institucionalização, resultando na conformação de diferentes e bem estabelecidas instâncias de gestão e negociação regionais. Outro fator favorável à regionalização é a articulação e o compartilhamento dos interesses entre os principais atores envolvidos, com fortalecimento dos conselhos municipais de secretários de saúde e das instâncias de gestão e negociação regionais, que contam com ampla participação dos gestores.

Goiás foi o único estado que apresentou um contexto político-institucional desfavorável. As razões para isso são: o peso do setor privado na oferta de serviços, concentrados na capital do estado; experiências prévias de regionalização com baixa institucionalidade e baixa racionalidade técnica de organização das redes assistenciais; pouca valorização da Comissão Intergestores Bipartite como instância de negociação intergovernamental; e falta de autonomia da Secretaria de Estado da Saúde para gerir o Fundo Estadual de Saúde, à época da pesquisa.

Em relação ao contexto conjuntural, os estados de Mato Grosso e Mato Grosso do Sul apresentaram tendências favoráveis à efetivação do processo de regionalização do SUS. Entre as principais razões para isso salientam-se: a consolidação do agronegócio como fonte de arrecadação crescente dos estados, que garante a sustentabilidade financeira das políticas públicas; a ampla base política dos governadores (mais de 50\% dos prefeitos compunham a mesma base dos governadores em cada um dos estados no período analisado); a regionalização é prioridade nas agendas estaduais e das secretarias estaduais de saúde; o perfil técnico dos gestores, com histórico de atuação nas políticas de saúde dos estados e 
municípios (atualmente, mais evidenciado no MS); e a valorização das instâncias regionais e de pactuação.

A conjuntura política da saúde goiana, entretanto, mantém-se em situação indefinida. Constatou-se uma instabilidade institucional dada a grande rotatividade dos gestores que ocuparam o cargo máximo da secretaria estadual de saúde no mandato anterior à realização da pesquisa. A renovação de mais de três quartos dos gestores municipais no último pleito, a maioria sem experiência na área da saúde pública, contribui também para reforçar a assimetria política entre SES e municípios, fragilizando ainda mais essa conjuntura decisória. Goiás se encontra numa situação de consolidação do agronegócio como fonte de arrecadação crescente, que favorece a capacidade estadual para investimentos na saúde, de priorização da regionalização na agenda estadual e ganhos para o perfil técnico dos gestores, com a vinda de pessoas experientes em políticas de saúde. Goiás ainda enfrenta sérios entraves nas relações do governo do estado com o da capital, além de dificuldades de fortalecimento das instâncias regionais e de pactuação intergestores.

Em relação à direcionalidade, o processo de regionalização da saúde no Centro-Oeste é orientado pelas ideologias da equidade, democrática-participativa e gerencial. A ideologia da equidade se expressa através de algumas estratégias, como os incentivos financeiros por parte do estado, que visam diminuir as desigualdades regionais quanto à capacidade instalada, ao acesso aos serviços e a integralidade das ações de saúde. A ideologia democrática-participativa relaciona-se à valorização do envolvimento dos atores governamentais e instâncias colegiadas no planejamento, gestão e regulação do sistema de saúde, assim como, da busca de maior transparência da gestão, através da transferência de poder decisório às instâncias regionais e da interlocução entre estado e municípios. A ideologia gerencial vincula-se ao estabelecimento de redes assistenciais e de regulação dos fluxos, com melhoria da assistência, da regulamentação da prestação privada e pela criação e/ou fortalecimento das estruturas regionais de gestão da saúde.

Os objetos da regionalização no Centro-Oeste são a organização de redes e fluxos e a ampliação da capacidade instalada (oferta). Estes objetos estão diretamente associados ao aumento dos recursos estaduais e municipais e à expansão da rede urbana ligados ao crescimento econômico e populacional vinculado ao agronegócio. 
Observa-se a preocupação com a implantação de sistemas de referência e contrareferência e indução de maior racionalidade na organização regional do sistema, para consolidar regiões de saúde com capacidade de planejamento e coordenação regional do SUS (qualificar a descentralização e a regionalização). A ampliação da capacidade instalada se vincula ao aumento de investimentos em equipamentos e ao credenciamento de serviços.

Quanto aos atores que participam do processo de regionalização, pode-se apontar o protagonismo das secretarias estaduais de saúde, incluindo suas instâncias regionais de gestão e prestação de serviços (hospitais regionais). Os municípios participam ativamente desse processo. Em relação às instâncias colegiadas, destacase a participação dos Conselhos de Secretários Municipais de Saúde, das Comissões Intergestores Bipartite e dos Colegiados de Gestão Regional (atuais CIR). A participação do setor privado é significativa, porém, velada em alguns casos (MS), por conta do peso na oferta hospitalar. No caso do Mato Grosso, os consórcios intermunicipais de saúde aparecem como importantes instâncias moderadoras dos interesses públicos e privados na saúde. Destaca-se também a importância das Instituições de Ensino Superior no processo de capacitação dos técnicos e gestores nas regiões de saúde.

Em relação aos instrumentos que subsidiam o processo da regionalização da saúde, destacam-se: portarias federais; planos e programação; relatório de gestão; termos de compromisso de gestão; resoluções da CIB; capacitação e apoio técnico; regulação; contratualização; e investimentos e incentivos financeiros para as regiões.

Nos estados do Centro-Oeste, a institucionalidade da regionalização da saúde varia de intermediária (GO, MS) a avançada (MT), com predominância da governança coordenada e cooperativa. Apenas em um estado não foi possível definir a governança (GO). Nos três estados, os impactos e inovações institucionais da regionalização em curso foram incrementais.

Os fatores que contribuem para a institucionalidade intermediária da regionalização são: a antiguidade do processo de regionalização, atualizado sem grandes modificações quanto ao desenho instituído no âmbito da Noas (GO); ser um processo ancorado nas características e peculiaridades regionais, ainda que seja mais recente, no caso do Mato Grosso do Sul; o desenho regional é setorial, com ênfase na organização de redes assistenciais, melhoria da oferta de serviços, do acesso e da 
gestão; as secretarias estaduais de saúde serem protagonista na condução do processo de regionalização, em crescente articulação com os conselhos de secretários municipais de saúde. Mato Grosso do Sul contava com grande apoio do Ministério da Saúde para o processo de regionalização, sendo o planejamento bastante centralizado no nível estadual, com limitações para sua efetivação e para a regulação, no âmbito regional; existem investimentos estaduais para a ampliação da capacidade instalada, entretanto, os incentivos financeiros para a regionalização são incipientes.

Alguns fatores contribuem para a institucionalidade avançada da regionalização no Mato Grosso. Apesar de o processo de regionalização ser recente, foi estruturado a partir da cooperação técnica entre os municípios e as instâncias regionais do estado, visando à organização das estruturas e instrumentos de gestão regional. O desenho regional não é setorial, casa com aquele proposto no Plano Estratégico de Governo, o que fortalece as estruturas regionais. O processo conta com o apoio do conselho de secretários municipais de saúde e do Ministério da Saúde. O foco da regionalização é a gestão da saúde no âmbito regional, considerando as necessidades e peculiaridades regionais e existem incentivos financeiros para a regionalização, considerando critérios de equidade. Identificam-se avanços quanto aos instrumentos de planejamento, porém, a regulação e a contratualização são incipientes.

Observa-se que a governança coordenada-cooperativa em MT e MS está condicionada ao maior envolvimento do conselho de secretários municipais de saúde e das instâncias regionais no processo; ao estabelecimento de relações cooperativas entre estado e municípios; ao fortalecimento e efetivação das funções dos Colegiados de Gestão Regional; à postura mais crítica dos municípios e a atuação coordenadora do estado; e à diversidade e consolidação das instâncias regionais existentes (no caso do MT). No âmbito das CIB, predominam as relações intergovernamentais cooperativas e interativas. O papel da CIB na regionalização foi classificado como indutor e consolidador, com elevada presença desse tema na agenda das Comissões.

No estado de Goiás, a indefinição do padrão de governança deve-se à fragilidade das representações municipais, com grande dependência da atuação do estado no processo; à baixa capacidade de influência dos Colegiados de Gestão Regional nos processos decisórios, porém, com grandes expectativas de mudança; 
aos mecanismos incipientes de coordenação das ações de regionalização, muito focados nos complexos reguladores; e às relações conflitivas entre o estado e a capital. O papel da CIB na regionalização ficou indefinido e verificou-se a fraca presença desse tema na agenda da comissão.

Quanto aos impactos e inovações institucionais decorrentes do processo de regionalização, destaca-se que foram incrementais, pois as instâncias regionais tiveram seu papel fortalecido, as secretarias estaduais de saúde atuam como coordenadoras do processo e os municípios têm amadurecido quanto ao seu papel e formas de articulação.

\subsection{Região Concentrada: contextos mais favoráveis, institucionalidade intermediária e avançada da regionalização do SUS}

A Região Concentrada se caracteriza pela mais elevada concentração econômica e populacional do país, com alto grau de diversificação, dinamismo, especialização e incorporação tecnológica e científica das atividades produtivas. Associa-se a isso a extensão de uma densa rede urbana, historicamente constituída, conectada por diversas redes de transporte e comunicação. Possui grande inserção no mercado global, sobretudo, pelas atividades produtivas mais especializadas e qualificadas, pelo mercado financeiro e pela concentração das sedes das empresas que comandam a produção e os investimentos no país e, por consequência, é uma região com grande influência sobre os projetos nacionais de desenvolvimento.

A Região Concentrada enfrenta desigualdades quanto à capacidade instalada e aos investimentos públicos e privados em saúde (possuindo o maior número de equipamentos, tecnologias, profissionais de saúde, usuários do SUS e beneficiários de planos de saúde). A consolidação de um mix público-privado na constituição do sistema e do mercado de saúde regional interfere fortemente no processo de reorganização da distribuição dos serviços e investimentos em saúde.

Os investimentos e equipamentos públicos e privados de saúde se estendem pelo interior dos estados, mas apresentam maior concentração nas capitais e regiões metropolitanas. Verifica-se a existência de alguns vazios assistenciais em áreas de 
menor densidade populacional e baixo dinamismo econômico, e a grande dependência de alguns municípios em relação aos polos regionais no que se refere aos tratamentos de atenção básica, média e alta complexidade pelo SUS, mesmo no âmbito das regiões metropolitanas. Os estados enfrentam dificuldade de promover a expansão do SUS através do planejamento e da realocação de investimentos no território, inclusive por conta do grande poder do setor privado na oferta e organização do sistema. Essa situação tem implicações negativas para a lógica pública e universal e para a expansão do sistema nas áreas mais carentes, sobretudo, no interior das regiões metropolitanas, concentradoras da riqueza e da pobreza ${ }^{127}$.

Quanto ao processo de descentralização, os estados da Região Concentrada se caracterizam pelos avanços obtidos na autonomia de boa parte municípios como gestores do sistema de saúde. A presença de uma densa rede urbana, com diversos polos regionais, favorece a descentralização e a regionalização da política e do sistema de saúde. Entretanto, ainda há situações de grande fragilidade e dependência dos municípios, sobretudo daqueles de menor porte populacional, em relação às capitais e governos estaduais para formulação, financiamento, regulação e planejamento da política de saúde.

Destaca-se o estado do Espírito Santo como um exemplo de grande dependência dos municípios quanto ao governo estadual, para planejamento, financiamento, regulação e gestão em saúde. Além da baixa capacidade técnica, os municípios também apresentam baixa capacidade de articulação política, contribuindo para a permanência do quadro de dependência em relação ao governo estadual. Minas Gerais também enfrenta essas dificuldades no processo de descentralização, pois $80 \%$ dos municípios têm menos de vinte mil habitantes e são muito dependentes do governo estadual para a efetivação das políticas de saúde. Em algumas regiões, há bolsões de pobreza e vazios assistenciais importantes. Nesses dois casos, verifica-se que as secretarias estaduais de saúde têm grande legitimidade técnica e política junto aos municípios.

\footnotetext{
${ }^{127}$ Processo caracterizado como involução metropolitana, por SANTOS (1990). O detalhamento dos dados sobre pobreza e riqueza das regióes metropolitanas pode ser verificado na obra de THÉRY, H e MELlo, N. A. Atlas do Brasil: Disparidades e Dinâmicas do Território. São Paulo: Editora da Universidade de São Paulo, 2005.
} 
Nos estados onde o processo de descentralização política está historicamente mais consolidado, como em São Paulo, Rio Grande do Sul e Paraná, verifica-se o protagonismo das secretarias estaduais de saúde e de certos polos regionais, como as sedes das regiões metropolitanas, na definição das políticas de saúde. Destaca-se o estado do Rio Grande do Sul como um exemplo importante da municipalização, sob coordenação formal da secretaria estadual de saúde, e da tradição participativa, associada à força política dos municípios.

O desenvolvimento econômico consolidado e difundido no território associado ao avançado processo de descentralização e à tradição de planejamento em saúde, com experiências prévias de regionalização, revelam um contexto históricoestrutural e político-institucional favoráveis para o processo de regionalização em curso nos estados da Região Concentrada. Apontam-se como exceções, os estados do Rio de Janeiro e de Santa Catarina.

Em São Paulo, Minas Gerais, Rio Grande do Sul e Paraná há experiências importantes de regionalização administrativa e setorial (saúde), favorecidas pela presença de identidades regionais fortes, relacionadas ao histórico da ocupação dos estados, e à tradição de planejamento em saúde e organização regional dos serviços. Nesses estados, a descentralização foi, em certo sentido, acompanhada por processos de regionalização, expressos pela existência de instâncias de pactuação regional (CIB microrregionais nos estados do Paraná, Rio Grande do Sul e Minas Gerais, e Escritórios Regionais de Saúde em São Paulo).

O estado do Rio de Janeiro apresenta um histórico de centralização decisória no âmbito do estado e forte presença política da capital na formulação das políticas de saúde estaduais. O processo de desenvolvimento econômico criou grandes desigualdades territoriais, como a alta concentração econômica e populacional na Região Metropolitana e no Médio Paraíba, ocasionando em forte assimetria de condições institucionais entre os municípios para a descentralização política na saúde. A descentralização teve enfoque exclusivamente municipalista, não sendo acompanhada de políticas de regionalização setorial. O Rio de Janeiro apresenta uma trajetória mais recente, ou tardia, de regionalização em saúde. Esse processo se caracteriza pela condução centralizadora do nível central, pouco participativa, com grande presença do estado na gestão de serviços e ausência de gestão regional. 
Já o estado de Santa Catarina, apesar do contexto histórico-estrutural mais favorável para a regionalização em saúde (conforme as características apontadas para toda a Região Concentrada), apresenta um contexto político-institucional desfavorável. As razões principais para essa situação são: a trajetória antiga, porém instável das experiências de regionalização da saúde no estado, com a existência de múltiplos recortes regionais não-coincidentes nos planos administrativo, políticoinstitucional da saúde e da atenção, dificultando a formulação de políticas regionais mais coerentes; a complexidade dos recortes regionais também coloca limites para avanços na governança regional; e o grande peso do estado na gestão e prestação de serviços, com tendência à concentração de poder no nível central e heterogeneidade das gerências regionais de saúde.

Em relação ao contexto conjuntural, todos os estados da Região Concentrada apresentaram uma tendência mais favorável, com exceção do Rio de Janeiro (indefinida). Apontam-se como principais fatores explicativos: a melhoria dos padrões de arrecadação, favorecendo grandes investimentos em saúde e apoio aos municípios; a priorização da regionalização nas agendas das secretarias estaduais de saúde e dos municípios; o perfil técnico dos gestores, com histórico de atuação nas políticas de saúde dos estados e municípios, e a valorização e fortalecimento das instâncias regionais para a efetivação do processo de regionalização; os conselhos de secretários municipais de saúde, com legitimidade de representação e importante papel técnico e político, têm se fortalecido com a nova regionalização; a valorização dos instrumentos de planejamento regional; a continuidade na gestão estadual em alguns estados favorece a condução da política de saúde.

No caso do Rio de Janeiro, apesar da aliança política importante firmada entre os governos estadual e federal, com grande apoio da capital, favorecer a introdução da agenda nacional na política estadual - incluindo a proposta de regionalização em saúde -, a priorização da regionalização na agenda do governo e da secretaria estadual de saúde ocorreu tardiamente. Soma-se a isso, o perfil e a trajetória dos dirigentes estaduais na política de saúde mais voltados para a gestão da alta complexidade e a participação em unidades federais de saúde. Essas condições tornam o contexto conjuntural indefinido quanto à tendência mais ou menos favorável à efetivação da regionalização. 
Nos estados da Região Concentrada, predominam as ideologias gerencial, democrática e da equidade na orientação da regionalização do SUS. A ideologia da equidade se expressa pela preocupação com a melhoria das condições de saúde, ampliação da oferta, do acesso e da integralidade, definição de fluxos e organização de redes assistenciais, com incentivos financeiros (também associados às especificidades regionais) e políticas específicas para qualificação da atenção básica nos municípios e desconcentração dos serviços dos polos regionais para regiões mais carentes. A ideologia democrática-participativa vincula-se ao aumento da participação dos gestores e técnicos estaduais e municipais no processo de planejamento regional, com a valorização e fortalecimento das instâncias de gestão e negociação intergovernamental, visando um maior equilíbrio de poder entre municípios (até então mais concentrado na atuação das capitais e polos regionais) ${ }^{128}$ e o fortalecimento da cooperação entre os entes governamentais na resolução de problemas de saúde. A ideologia gerencial relaciona-se com a organização de processos e fluxos para aumentar a capacidade gerencial, planejadora e reguladora dos atores governamentais estaduais e municipais, inclusive sobre os prestadores privados (filantrópicos); com a melhoria da capacidade institucional do estado para qualificar os instrumentos de planejamento regional; com a otimização da distribuição espacial dos recursos e racionalização de gastos; com o fortalecimento do papel do estado como coordenador, planejador e investidor regional do SUS; com a qualificação do processo de descentralização municipal.

O objeto da regionalização nos estados da Região Concentrada são a organização de redes e fluxos e a ampliação da capacidade instalada (oferta).

O foco na organização de redes e fluxos em saúde tem relação, por exemplo, com as dificuldades de planejamento regional e reordenamento da rede assistencial nos estados muito dependentes da oferta privada de serviços de saúde (PR, RS). A organização de redes e fluxos também se relaciona com a tentativa de superação dos

\footnotetext{
128 Esse movimento repercutiu no estado de São Paulo através, por exemplo, da mudança na nomenclatura das regiões de saúde. Tradicionalmente as regiões recebiam o nome do município polo. No processo pós-Pacto pela Saúde, algumas regiões de saúde mudaram suas denominações considerando a localização no estado ou especificidades regionais (Alto Tietê, Mananciais, Rota dos Bandeirantes, Central, Centro-Oeste, Norte, Consórcios, Baixada Santista, Alta Anhanguera, Alta Mogiana, Baixa Mogiana, Vale do Paraíba, Região Serrana, Mantiqueira, Pontal Paranapanema, Alta Paulista, entre outras).
} 
problemas da regulação dos fluxos assistenciais (atomização dos municípios) e da competição entre os entes federados por recursos (SP, RJ); e com a indução de maior racionalidade regional para o funcionamento do sistema, visando melhoria na descentralização, no acesso e na resolutividade nos atendimentos (MG). No caso de Minas Gerais, destaca-se o debate avançado sobre a estruturação de redes de saúde para ampliação do acesso em áreas/serviços específicos, com redes estaduais definidas em consonância com as regiões de saúde estabelecidas.

O foco na ampliação da capacidade instalada se relaciona à revisão da PPI para redefinição dos investimentos nas regiões de saúde constituídas pós-Pacto pela Saúde, definindo recursos per capita por região, relacionados às linhas de cuidado do plano estadual, e buscando novos recursos oriundos das portarias ministeriais (SP). Em São Paulo, os novos investimentos estaduais para ampliação da capacidade instalada não entraram no processo de negociação intergovernamental no âmbito dos Colegiados de Gestão Regional (são negociados apenas a localização dos equipamentos e o tipo de especialidade). Em Minas Gerais, os novos investimentos estão relacionados à estruturação e expansão das redes assistenciais estaduais e à contratualização de prestadores públicos e privados, com alocação dos recursos estaduais seguindo estratégias redistributivas e projetos prioritários para as regiões de saúde.

No processo de regionalização nos estados da Região Concentrada, destaca-se o protagonismo das secretarias estaduais de saúde e a importante atuação dos municípios. As instâncias colegiadas também aparecem como atores relevantes da regionalização - Conselhos de Secretários Municipais de Saúde, Comissões Intergestoras Bipartite e Colegiados de Gestão Regional. Consórcios intermunicipais de saúde e os prestadores privados atuam no processo de regionalização, ainda que de forma indireta. Em São Paulo, as universidades públicas aparecem como instituições apoiadoras desse processo. Apenas no estado do Rio de Janeiro se observa a importância da participação federal na regionalização.

As principais estratégias voltadas para a regionalização do SUS nos estados da Região Concentrada são: a criação e/ou fortalecimento de instâncias de pactuação regional; a criação e/ou revisão dos instrumentos de planejamento, gestão e regulação; reformas administrativas das secretarias estaduais de saúde; ampliação e 
melhor distribuição espacial dos recursos financeiros e investimentos, sobretudo, em equipamentos de alta complexidade; o fortalecimento da gestão pública estadual e municipal nas regiões; e a ampliação da participação de atores não governamentais no processo de regionalização.

Dentre os principais instrumentos que subsidiam o processo de regionalização nos estados, estão: portarias federais; incentivos financeiros e investimentos; criação de normas e incentivos estaduais específicos; planos e programação; capacitação; contratualização; regulação; desenho de redes assistenciais específicas; processos participativos; e lei dos consórcios.

$\mathrm{Na}$ Região Concentrada, a institucionalidade da regionalização apresentou padrão intermediário e avançado, e a governança se caracterizou pela predominância de relações coordenadas e cooperativas, sendo indefinida apenas para o Rio de Janeiro.

Os fatores que contribuem para a institucionalidade intermediária (RS, SC, RJ, ES) da regionalização são: a regionalização da saúde é um processo ainda em fase de elaboração (RJ); uma trajetória antiga da regionalização, porém, com instabilidade desse processo (várias mudanças ao longo do tempo) e conflitos em relação à multiplicidade de recortes não coincidentes (SC); o desenho das regiões de saúde coincide com a divisão político-administrativa do estado, mas não incorpora variáveis da saúde $(\mathrm{RJ})$, ou o desenho regional é estritamente setorial, determinado pela distribuição da oferta de serviços (ES); as regiões têm forte identidade territorial e solidez quanto aos seus desenhos (próprio da saúde), entretanto, verifica-se uma grande heterogeneidade regional quanto à capacidade instalada assistencial (RS); predominam as estratégias tradicionais de regulação, com dificuldades de consolidação de novos mecanismos; a assistência e a organização de redes representam grande peso na regionalização, orientada pela organização de fluxos e melhoria do acesso; as secretarias estaduais exercem protagonismo (às vezes muito centralizado) no planejamento regional; existem limitações quanto ao financiamento e ao planejamento dentro da lógica regional. Chama a atenção para o fato da institucionalidade da regionalização não estar avançada no Rio Grande do Sul, no momento de realização da pesquisa. O histórico de conformação das regiões no estado é antigo, guardando relação com os movimentos de descentralização política, 
dos usos do território e do desenvolvimento econômico e social, que foi bastante heterogêneo e desigual. Essa heterogeneidade regional observada no estado, de raízes antigas, associada ao número de municípios de pequeno porte, influencia a regionalização da saúde negativamente, pois resulta numa grande concentração da oferta assistencial na capital e em alguns municípios polo, além de variações importantes entre as regiões de saúde quanto à capacidade institucional das estruturas regionais do estado e dos municípios. Além disso, a existência de diferentes recortes regionais sobrepostos (administrativo, da saúde, conselhos representativos e regiões de desenvolvimento) dificulta a articulação de políticas para redução das desigualdades entre as regiões de saúde.

Os principais fatores que contribuem para a institucionalidade avançada da regionalização (PR, MG, SP) são: acúmulo de experiências históricas de regionalização na saúde e a permanência dos desenhos regionais por longo período; desenho regional setorial, com ênfase nas identidades históricas e culturais de organização do sistema de saúde, com a existência de polos regionais e participação dos municípios; a regionalização ocupa papel central nas agendas estaduais e municipais e está voltada para a organização de redes e fluxos, ampliação do acesso e da capacidade instalada, com grande importância dos investimentos das secretarias estaduais de saúde, definidos em parceria ou não com os municípios; o protagonismo da secretaria estadual de saúde na condução da regionalização; as estruturas regionais são diversificadas, estão consolidadas, mas passam pela requalificação de sua atuação e redefinição de seus papéis; a busca de qualificação da descentralização com a regionalização; processo voltado para o diagnóstico das demandas regionais em saúde, diminuição das desigualdades regionais quanto a oferta de serviços e fortalecimento das diretrizes do SUS; revisão e qualificação dos instrumentos de planejamento e regulação; a regulação está baseada em diversos instrumentos, como contratualização e complexos reguladores, porém ainda necessita de maiores investimentos e avanços em relação à formulação de um projeto de regulação mais efetivo e abrangente; existem estratégias de capacitação técnica dos gestores estaduais e municipais ligadas ao processo de regionalização.

Quanto à governança do processo de regionalização, observa-se que a governança cooperativa (SC) está condicionada pela inovação que os Colegiados de 
Gestão Regional representam parar o processo político regional (melhoria de articulação entre os municípios), sobretudo, nas áreas onde as instâncias regionais do estado são frágeis.

Já a governança coordenada-cooperativa (RS, PR, SP, MG, ES) caracteriza-se pela presença de mecanismos de coordenação entre atores relevantes para a regionalização, como canais para processamento dos conflitos e instâncias regionais consolidadas; pelo bom padrão de relacionamento entre as estruturas regionais dos estados e dos municípios, sem grandes conflitos no âmbito regional; as secretarias estaduais de saúde exercem importante papel no planejamento e no financiamento regional (MG e SP); pela boa capacidade técnica das instâncias regionais e a boa capacidade de articulação dos municípios, embora ainda existam diferenças importantes na atuação das instâncias regionais e na capacidade de articulação dos municípios; os mecanismos de coordenação estão sendo fortalecidos através da regulação e da revisão dos instrumentos de planejamento, contudo, verifica-se a forte influência do setor privado (na oferta de saúde) na efetivação das políticas regionais de assistência, contrária à lógica de expansão dos investimentos nas áreas mais empobrecidas.

Apenas no estado do Rio de Janeiro não foi possível definir o padrão de governança. Apontam-se como características importantes: o histórico de centralização política na capital e a concentração do poder decisório no âmbito federal, favorecendo relações bilaterais; falta de avanços na utilização de outras estratégias de regulação, além das tradicionais; implantação incipiente dos Colegiados de Gestão Regional (no momento de realização da pesquisa); as iniciativas mais antigas de criação de consórcios intermunicipais não estão necessariamente em diálogo com a regionalização em curso; predominância das relações cooperativas entre a secretaria estadual de saúde e o conselho de secretários municipais de saúde, mas com áreas de conflitos ainda relevantes.

Destaca-se a importante atuação das Comissões Intergestores Bipartite (CIB) para o predomínio da governança cooperativa e coordenada do processo de regionalização do SUS nos estados da Região Concentrada. Observa-se seu papel mais orientador/facilitador e consolidador nos estados onde a regionalização apresentou institucionalidade intermediária (ES, RJ, SC), e seu papel fortemente 
indutor e consolidador nos estados em que a institucionalidade da regionalização se mostrou avançada (PR, MG, SP).

No estado do Rio Grande do Sul, apesar da institucionalidade intermediária da regionalização, a CIB teve importante papel indutor e consolidador na regionalização, favorecendo a governança coordenada e cooperativa. O Rio Grande do Sul foi o único estado onde estava sendo discutida, no momento de realização da pesquisa, a possibilidade de retomada do funcionamento dos conselhos regionais de saúde, a exemplo dos conselhos municipais e estadual, para ampliar a participação da população no processo de regionalização.

Os impactos e inovações institucionais relacionados ao processo foram incrementais, com exceção do Rio de Janeiro (embrionários). As experiências anteriores de regionalização condicionaram o processo recente, com mudanças incrementais no que concerne ao papel do estado, aos instrumentos de planejamento e regulação, ao desenho regional, aos investimentos regionais, ao sistema de saúde e à coordenação intergovernamental. Principais impactos: fortalecimento do papel condutor, regulador e planejador do estado, assim como, de suas instâncias regionais; e um maior amadurecimento e fortalecimento da participação dos municípios e dos conselhos de secretários municipais de saúde. No Rio de Janeiro os impactos da regionalização foram embrionários, porque, apesar da constituição das instâncias regionais de saúde, as mudanças na cultura técnica da secretaria estadual de saúde ainda eram iniciais.

\subsection{Aprendizados e desafios}

$\mathrm{Na}$ fase da "regionalização viva" (Pacto pela Saúde, 2006), as diretrizes nacionais induziram mudanças significativas no processo de regionalização do SUS empreendido nos estados, sobretudo, no exercício do poder no interior da política de saúde. A regionalização deixou de ser um processo estritamente técnico e normativo, para se consagrar como um processo político, fundamentalmente dependente da negociação intergovernamental (ALBUQUERQUE et al, 2011).

Nesse sentido, houve a necessidade de revisão dos papéis dos estes federados no planejamento, no financiamento e na condução da organização regional do 
sistema, demandando ampla participação dos gestores estaduais e municipais nos espaços de negociação estaduais e regionais, além de um posicionamento claro em relação às regras, instrumentos, investimentos, objetivos e orientações da regionalização.

Por um lado, os municípios ampliaram sua importância na definição dos rumos da política de saúde estadual e nas regiões de saúde. De maneira geral, os Colegiados de Gestão Regional (atuais Comissões Intergestores Regionais) foram vistos como espaços de negociação que possibilitam maior influência das demandas municipais - consolidadas em demandas regionais - na definição das políticas estaduais de saúde; percepção presente em todos os estados analisados (mesmo naqueles onde os CGR ainda não haviam sido instituídos ou estavam em processo de consolidação no momento de realização da pesquisa). O papel dos Conselhos de Secretários Municipais de Saúde (Cosems) também se fortaleceu como canalizadores e tradutores da posição dos municípios em relação à regionalização e às políticas estaduais. Isso aconteceu tanto em estados onde historicamente o processo de descentralização foi mais precário e os municípios tendem a sofrer com a baixa capacidade técnica e política de atuação, organização e articulação em torno do planejamento regional, quanto em estados em que a descentralização e a regionalização são processos mais antigos e consolidados. Neste caso, os Cosems costumam ser os principais interlocutores entre estados e municípios, com ganho de autonomia destes para a pactuação regional e para as relações entre as secretarias estaduais e os conselhos. $\mathrm{O}$ aumento da participação e da representatividade regional dos Cosems fortalece seu papel técnico e político nos fóruns de deliberação da política de saúde, contribuindo também para a construção da visão regional do planejamento e regulação do SUS por parte dos municípios.

Por outro lado, os estados conquistaram um papel mais voltado para a coordenação, o planejamento, a regulação e o investimento regional do SUS, em contraste com o antigo papel de provedores de serviços de saúde. Esse novo posicionamento rompe com a lógica estruturada no processo de descentralização, em que a União estabelecia uma relação direta com os municípios, sem tratar de forma adequada o papel das esferas estaduais na indução da cooperação intermunicipal e coordenação da organização regional do sistema. 
Uma das principais estratégias adotadas pelos estados para garantirem esse novo papel foi a criação ou reestruturação das instâncias regionais das Secretarias Estaduais de Saúde. São essas instâncias que possibilitam um relacionamento mais próximo das Secretarias como os CGR (atuais CIR) e favorecem a negociação e a coordenação regional. As Comissões Intergestores Bipartite também passaram por um processo de legitimação e fortalecimento, resultando numa maior qualificação das discussões sobre a política de saúde e aderência das pautas às demandas e realidades estaduais, municipais e regionais (MACHADO et al., 2011).

As mudanças induzidas pelo processo de regionalização nos estados evidenciaram a necessidade de revisão e introdução de novos instrumentos, para dar conta dos objetivos, estratégias e orientação do novo processo. Contudo, o Pacto pela Saúde não trouxe alterações significativas em relação aos instrumentos de planejamento e gestão regional do SUS. A revisão daqueles já existentes nos estados (notadamente a PPI) não evoluiu a contento das necessidades de mudanças, sobretudo, no que se refere à tendência de ampliação da capacidade instalada (oferta) via aumento dos investimentos estaduais em saúde. Alguns estados adotaram a estratégia de elaboração de novos instrumentos no âmbito da política estadual, voltados para a regionalização.

O financiamento e a negociação regional sobre a distribuição dos recursos estaduais e federais de saúde apareceram como um dos principais entraves para a regionalização pós-Pacto pela Saúde. Ficou patente a necessidade de ampliação dos debates e negociações intergovernamentais sobre os investimentos regionais em saúde, considerando-se os gastos provenientes das três esferas de governo. Uma das questões mais graves diz respeito à garantia de que o recente aumento dos investimentos estaduais em saúde rompa com a lógica de produção de desigualdades espaciais na destinação dos recursos da saúde (concentração nas capitais, regiões metropolitanas, polos regionais e distribuição com base na pressão do setor privado filantrópico). Não foram observados inovações ou avanços significativos nos mecanismos de financiamento da saúde no âmbito do novo processo de regionalização. A principal mudança identificada foi a de que os CGR eram vistos como os espaços privilegiados para aproximação entre as lógicas de investimento estaduais e municipais, numa dada região. Nos estados onde existe a preocupação de 
limitar o poder dos interesses privados na definição dos investimentos regionais em saúde, esperava-se que os CGR exercessem um papel decisivo no fortalecimento da decisão pública sobre a desconcentração dos gastos e ampliação da capacidade instalada nas regiões mais carentes.

A regulação é outro entrave importante da regionalização do SUS pós-Pacto pela Saúde. Os estados não foram capazes de construir um projeto de regulação mais robusto e capaz de fortalecer a lógica pública de planejamento e contribuir para a estruturação de redes e fluxos assistenciais nas regiões. Verificaram-se apenas avanços pontuais, como a implantação de complexos reguladores ou a contratualização. Os conflitos relacionados à falta de melhorias na regulação da saúde são os mesmos apontados para o financiamento: desigualdades regionais de oferta dos serviços - regiões concentradoras e regiões de vazios assistenciais. Os desafios da regulação se acentuam nos estados onde existe um forte setor privado na saúde (lucrativo e filantrópico) e onde o processo de descentralização ainda enfrenta dificuldades, resultando na baixa capacidade dos municípios para construírem estratégias de regulação. Os CGR apareceram como espaços privilegiados para a negociação e resolução de conflitos em torno da regulação do sistema, pois passaram a ter poder de decisão sobre cadastramentos, contratualizações, implantação de complexos reguladores, entre outros instrumentos de regulação. Nos estados onde existem consórcios intermunicipais de saúde, os desafios da regulação aumentaram, já que eles fazem sua própria regulação, muitas vezes com recortes regionais diversos daqueles pactuados nos instrumentos da regulação e, naturalmente, do desenho dos CGR. Outro desafio é romper com a competição entre estados e municípios por recursos e com a lógica de atomização de alguns municípios polos.

As desigualdades espaciais de conformação do sistema de saúde e a alta dependência da oferta privada em alguns estados ajudam a explicar as dificuldades impostas para o planejamento, financiamento e regulação regional. A revisão do desenho regional e da PPI tornou mais evidente a atuação dos prestadores privados (filantrópicos) junto à definição das políticas regionais, sobretudo, no que se refere à destinação dos investimentos públicos estaduais em saúde. Em alguns estados, vê-se o poder público praticamente "refém" dos prestadores privados filantrópicos, que detêm a maior parte da oferta de serviços e das informações sobre o uso destes, 
exercendo grande pressão na organização e na destinação dos investimentos do sistema. A participação do setor privado na regionalização é mais velada em certos estados do que em outros, onde os prestadores participam, por exemplo, de reuniões das CIB (as reuniões dos CGR não são abertas, mas há casos em que os gestores decidem convidar os prestadores para esclarecimentos ou apresentação de propostas de serviços para contratualização).

A relação entre Estado e Mercado - questão crucial para entender a divisão territorial e regional do trabalho na saúde - ainda não foi devidamente contemplada pelas diretrizes e nos processos de regionalização do SUS, seja do ponto de vista dos conflitos existentes entre a lógica pública e privada (BAHIA, 2005), da conformação e regulação dos diversos arranjos público-privados assistenciais e produtivos na saúde (IBAÑEZ et al., 2009; VIANA \& SILVA, 2012) e da interdependência e cooperação entre os setores público e privado em relação à oferta, ao planejamento e financiamento da saúde (COELHO, 2011; MARTINELLI et al, 2014), seja do ponto de vista da crescente pressão para incorporação de conteúdos tecnológicos e científicos no sistema de saúde, característica da lógica de inovação e acumulação de capital associada ao setor (VIANA \& SILVA, 2012; ALBUQUERQUE, 2012).

O processo de regionalização pós-Pacto pela Saúde incentivou uma discussão mais ampla sobre a governança ${ }^{129}$ regional na saúde. A diversidade de ideologias que orientaram esse processo mostrou que as mudanças induzidas na política de saúde abriu caminho para um conjunto mais amplo de ideias e valores, e chama atenção a multiplicidade dos atores e espaços de negociação e decisão associados ao processo de regionalização nos estados. Fato evidente foi o protagonismo das Secretarias Estaduais de Saúde para determinar a institucionalidade avançada e a governança coordenada e cooperativa do processo de regionalização da saúde nos estados. Se por um lado, houve a diversificação da participação dos atores governamentais e dos prestadores, assim como, dos espaços de negociação, por outro, a participação dos usuários permanece restrita aos conselhos estaduais e municipais de saúde (de modo geral pouco integrado). A criação de conselhos regionais de saúde esteve em debate apenas no Estado do Rio Grande do Sul. No estado do Piauí, os Conselhos de

\footnotetext{
129 “A regionalização implica numa mudança no exercício de poder (redistribuição de poder) no interior da política de saúde o que se traduz na introdução de novos atores, objeto, normas e processos, governado/liderado por diferentes orientações/ideologias" (VIANA \& LIMA, 2011, p.12).
} 
Desenvolvimento Territorial Sustentável ${ }^{130}$ contribuem para diversificar a participação da sociedade no campo da saúde, entretanto, sem ainda desenvolverem uma relação direta com os CGR. Verificou-se uma participação mais próxima no processo da regionalização das universidades (com apoio técnico para qualificação dos gestores e do processo de regionalização); de Assembléias Legislativas dos Estados (com aprovação de um conjunto de Leis que subsidiam a regionalização); e de Consórcios de Saúde (com a organização da oferta de serviços de saúde nas regiões).

Segundo Coelho (2011), as dificuldades de governança das regiões de saúde estão fortemente associadas às relações de cooperação e interdependência entre as lógicas de regionalização da oferta de ações e serviços do subsistema público e do privado lucrativo. Os padrões de relacionamento (formais e informais) estabelecidos entre prestadores, operadoras de planos de saúde e as instâncias de gestão do SUS fragmentam a lógica do planejamento regional, expressando inclusive os conflitos entre os papéis exercidos por estas instâncias nas regiões. De acordo com a autora, são elementos condicionantes dos padrões de relacionamento entre Estado e Mercado no sistema de saúde os aspectos histórico-estruturais das regiões, a atuação da corporação médica e das organizações filantrópicas, a capacidade de oferta de serviços e os mecanismos político-institucionais do Estado. Nesse sentido, concordase com a autora sobre a necessidade de se pensar a governança da regionalização de forma mais ampla, incorporando nas instâncias de negociação intergovernamentais a atuação de outros atores e instituições na oferta de serviços, no planejamento, na regulação e no financiamento do sistema, de forma garantir maior transparência e formalização da relação entre Estado e Mercado no sistema e na política de saúde.

Observaram-se também desafios relacionados à reorganização dos desenhos regionais do SUS em alguns estados, a partir da implantação das diretrizes do Pacto pela Saúde, seja em função de um processo de dissociação entre a regionalização administrativa dos estados e a regionalização do SUS, para melhor adequação ao funcionamento das redes e fluxos assistenciais e ao padrão de relações intergovernamentais no âmbito da política de saúde; seja em função da submissão da

\footnotetext{
${ }^{130}$ De acordo com a Lei Complementar $n^{\circ} .87$, de 2007.
} 
organização regional do SUS aos recortes regionais de desenvolvimento econômico e social, definidos para servirem de base comum a todas as políticas estaduais.

Os desafios para a definição dos desenhos regionais do SUS se aprofundam nos estados da Amazônia, por conta da baixa densidade urbana e populacional e fragmentação da rede urbana, associada às longas distâncias e condições das vias de transporte e comunicação. Se, por um lado, alguns autores observaram a pouca relação existente entre o ordenamento territorial do estado, baseado nas características e hierarquias urbanas, e a configuração das regiões de saúde (caso do estado de São Paulo, estudado por Duarte et al., 2013). Por outro lado, as regiões de saúde dependem fundamentalmente da existência de redes e fluxos assistenciais (ainda que constituídos de forma espontânea ou com baixa condução pelo planejamento do SUS). Estes, por sua vez, são fortemente condicionados pela existência e densidade das redes e fluxos urbanos (mais rarefeitos na Amazônia, ainda que se constitua uma floresta urbanizada, segundo definição de Becker, 2003).

A existência de distintos recortes regionais segundo diferentes políticas setoriais, regiões administrativas, áreas de abrangência de instâncias e conselhos representativos ou mesmo por conta da criação de regiões de desenvolvimento nos estados, às vezes é considerada um problema pela dificuldade de articulação das políticas intergovernamentais e setoriais, mas, por outro lado, a uniformização dos desenhos regionais (um só desenho para todas as políticas) não seria fácil. A política de saúde, por exemplo, apresenta especificidades importantes, ligadas às condições sociais, técnicas e políticas (relações intergovernamentais) para a estruturação das redes regionalizadas e fluxos assistenciais intermunicipais (acesso).

O processo de regionalização do SUS nos estados brasileiro, pós-Pacto pela Saúde, deixou claro que a regionalização depende de uma base técnica e política para ser institucionalizada, mas, também, que o conceito de região de saúde e seus instrumentos deveriam ser repensados, para que o financiamento, a regulação, o planejamento regional se tornassem mais efetivos para a estruturação de redes assistenciais e diminuição das desigualdades socioespaciais na universalização da saúde.

A investigação evidenciou a grande diversidade e desigualdade entre as regiões de saúde (tipologias) e o processo de regionalização nos estados (contextos, 
direcionalidade, institucionalidade e governança) (ALBUQUERQUE et al., 2011). Os fatores de natureza histórico-estrutural, conjuntural e de ordem políticoinstitucional mostram-se determinantes para o entendimento dos avanços conseguidos e dificuldades enfrentadas.

A análise empreendida indicou forte condicionante das situações geográficas que caracterizam os "quatro Brasis" sobre o processo de regionalização do SUS nos estados, no momento de implantação do Pacto pela Saúde (2007-2010). As dificuldades e os desafios desse processo se aprofundam conforme a região (Amazônia, Nordeste, Centro-Oeste e Região Concentrada).

Na Amazônia, verifica-se que condições estruturais da rede urbana e de fluidez territorial, associada à extensão territorial, às intensas migrações internas e externas, à diversidade cultural e à rapidez com que chegam investimentos vultuosos nacionais e internacionais em grandes projetos de infraestrutura, extrativismo e agropecuária, conformando antigos e novos polos regionais, resultam em dificuldades importantes para a conformação das redes e fluxos assistenciais do SUS, assim como, dos espaços colegiados e das políticas regionais de saúde. As dificuldades principais relacionadas ao processo de regionalização do SUS parecem resultar: (i) das escassas e precárias experiências de regionalização na política de saúde; (ii) de certos padrões conflitivos e pouco coordenado nas relações intergovernamentais, muitas vezes ligados às dificuldades de descentralização, financiamento e planejamento por parte dos municípios, mas, também das secretarias estaduais, com forte dependência federal para a condução desse processo; (iii) das dificuldades de participação dos gestores nas instâncias de planejamento regional do SUS e de estabelecimento de fluxos assistenciais, dadas as longas distâncias e características das redes de fluidez territorial; (iv) das dificuldades de criação e fortalecimento de instâncias regionais de planejamento e gestão do SUS; (v) da existência extensos de vazios assistenciais em áreas empobrecidas e de baixa densidade técnica, populacional e urbana, que não são atrativas para os investimentos públicos e privados, assim como, para os profissionais de saúde; e (vi) das dificuldades de financiamento e investimento no sistema, consequência, dentre outras coisas, da dinâmica econômica regional. Observam-se o importante papel dos conselhos de secretários municipais de saúde para articular os gestores municipais, 
estabelecer relações intergovernamentais mais cooperativas e influenciar o processo de regionalização do SUS nos estados.

$\mathrm{Na}$ região Nordeste, as desigualdades socioespaciais e econômicas são profundas e a rede urbana se estende por manchas, concentrando serviços, população, atividades produtivas, investimentos e fluidez nas capitais e poucos polos regionais no interior dos estados. Essas condições dificultam a conformação das redes e fluxos assistenciais. Mas, a antiguidade dos usos do território e de formação dos estados, e de suas políticas de saúde, resultou em processos também antigos de planejamento regional (regiões administrativas e/ou setoriais de saúde) e de integração urbana e regional, assim como, na formação de um quadro técnico e político ligado historicamente à área da saúde, com larga experiência em planejamento e gestão do sistema. A antiguidade das regionalizações administrativas e de saúde não criaram, necessariamente, colegiados regionais, mas as secretarias estaduais são protagonistas na condução da regionalização do SUS. Observam-se exemplos importantes de conselhos e colegiados gestores com forte atuação técnica e política, e legitimidade para influenciar o processo de regionalização do SUS. As dificuldades principais desse processo parecem resultar: (i) de certos padrões conflitivos e pouco coordenado nas relações intergovernamentais, muitas vezes ligados às dificuldades de descentralização; (ii) da existência de vazios assistenciais em áreas empobrecidas e de baixa densidade técnica, populacional e urbana, que não são atrativas para os prestadores privados (lucrativos e filantrópicos) e profissionais de saúde; e (iii) das dificuldades de financiamento e investimento no sistema para ampliação da capacidade instalada, consequência, dentre outras coisas, da dinâmica econômica regional; (iv) das dificuldades de reorganização dos desenhos regionais de saúde, seja criando desenhos próprios ou adequando-os a outras regionalizações (administrativas, de desenvolvimento, etc.); (v) da necessidade de construção e/ou fortalecimento das instâncias de planejamento e negociação intergovernamentais; (vi) da falta de priorização da regionalização por parte de algumas secretarias estaduais.

No Centro-Oeste, a desconcentração da rede de serviços de saúde do SUS e os avanços na descentralização política acompanharam a conformação de polos urbanos regionais, tanto aqueles mais antigos e quanto aqueles ligados à atual 
expansão econômica do agronegócio e à densificação populacional nos estados. As experiências recentes de planejamento regional na área da saúde não constituem um fator limitante para o atual processo de regionalização do SUS, dado o comprometimento técnico e político das secretarias estaduais desde o início das experiências e o estabelecimento de instâncias estaduais de planejamento nas regiões de saúde. Soma-se a isso o fato de que o alto dinamismo econômico, a atração e concentração populacional nos polos regionais e o aumento da fluidez territorial têm contribuído para a estruturação de redes regionalizadas de saúde e, também, para os ganhos técnicos, políticos e econômicos por parte das secretarias estaduais e municipais (capitais e polos regionais) para implantação das políticas de saúde e qualificação do processo de descentralização. As regiões de saúde constituídas com base nas redes urbanas tendem a manter seus recortes originais, facilitando o aprendizado institucional e a negociação intergovernamental. Por outro lado, a grande polarização dos municípios sedes das regionais, concentradores da oferta assistencial, muitas vezes dificulta as negociações em torno dos fluxos e atendimentos às demandas regionais. Observam-se $\mathrm{o}$ interesse dos gestores municipais em relação à regionalização do SUS e a importante atuação técnica e política de seu conselho representante, com legitimidade para influenciar esse processo. As dificuldades principais da regionalização do SUS recaem sobre: (i) a existência de vazios assistenciais, sobretudo, nas áreas mais distantes dos polos regionais; (ii) a grande concentração de oferta de serviços, recursos financeiros, profissionais e usuários nas capitais e nos polos regionais (tanto naqueles mais antigos, quanto naqueles conformados a partir da dinâmica econômica do agronegócio); (iii) as dificuldades de descentralização em parte dos municípios e as desigualdades existentes entre eles quanto às capacidades técnicas e financeiras para a execução das políticas de saúde; (iv) dificuldades de negociação com os municípios polo; (v) a necessidade de apoio do governo federal no processo de regionalização e tendências de centralização do planejamento na esfera estadual; (vi) o enfrentamento do peso do setor privado na oferta assistencial e sua influência no planejamento regional.

Finalmente, na Região Concentrada, a densa e extensa rede urbana, o dinamismo econômico e a trajetória da política de saúde, incluindo estratégias de 
planejamento regional, favoreceram a conformação e a expansão dos serviços de saúde pelo interior dos estados. Ainda assim, existem regiões de vazios assistenciais e uma grande concentração das ações e serviços de saúde públicos e privados lucrativos nas capitais, alguns polos regionais e regiões metropolitanas. Destaca-se que mesmo nos estados da Região Concentrada, com experiências históricas de regionalização do sistema de saúde, além da boa capacidade técnica, política e financeira dos governos estaduais e municipais para a execução das políticas de saúde, o processo de regionalização desencadeado pós-Pacto pela Saúde enfrenta algumas dificuldades. Estas se relacionam, principalmente, com (i) a necessidade de capacitação das equipes regionais das secretarias estaduais e de fortalecimento das instâncias regionais de planejamento e gestão das secretarias estaduais; (ii) o processo de descentralização em parte dos municípios e o protagonismo de certos polos regionais, metrópoles e das capitais nas definições das políticas de saúde; (iii) a complexa negociação sobre os investimentos estaduais em saúde, no âmbito das regiões constituídas; (iv) a necessidade de ampliação dos investimentos estaduais no sistema; (v) a dificuldade de expansão das ações e serviços em áreas de vazios assistenciais, incluindo estratégias de enfrentamento da lógica privada e fortalecimento da lógica pública e universal na organização das redes de serviços; (vi) a estruturação de redes assistenciais regionalizadas.

Atualmente, na transição da "regionalização viva" para a "regionalização contratualizada" (Decreto 7.508/11), verifica-se que os estados brasileiros que já assinaram o Contrato Organizativo da Ação Pública de Saúde - Coap (CE, MS) ou estão elaborando este documento (SE, SP e MG) localizam-se no Nordeste, CentroOeste e Região Concentrada e apresentaram uma institucionalidade avançada ou intermediária da regionalização do SUS e governança coordenada/cooperativa desse processo.

No Nordeste, o Ceará foi o primeiro estado brasileiro a assinar os Coap regionais, com exceção da região de saúde de Fortaleza. Além dos condicionantes positivos para a regionalização do estado, com destaque para a atuação da secretaria estadual de saúde e do conselho dos secretários municipais de saúde, aponta-se como fator importante para a adesão às diretrizes da regionalização contratualizada o fato do gestor federal responsável pela condução da elaboração das diretrizes do Decreto 
7.508/11 e seus dispositivos, Secretário de Gestão Estratégica e Participativa (SGEP/MS), ser cearense e possuir larga experiência e participação nas políticas de saúde.

No caso de Sergipe, experiência que serviu de base para as diretrizes do Decreto 7.508, os contratos estabelecidos durante a implantação do Pacto pela Saúde estão sendo considerados (com as devidas adaptações) nessa nova fase da regionalização do SUS.

No Centro-Oeste, o estado do Mato Grosso do Sul já iniciou a elaboração e assinatura dos Coap em suas regiões de saúde. Os aspectos elencados como condicionantes favoráveis ao processo de regionalização no estado favoreceram sua rápida adesão ao Coap, enfatizando-se a importância do perfil e da trajetória da secretária estadual de saúde, com longa permanência no cargo e participação ativa nas comissões intergestores, como no caso da Comissão Intergestores Tripartite (CIT), e no processo de implementação e avaliação das novas diretrizes trazidas pelo Decreto 7.508/11.

Na Região Concentrada, destaca-se que o estado de Minas Gerais tem investido na estruturação de redes de atenção à saúde associada ao processo de regionalização desde a fase do Pacto pela Saúde, sob a orientação dos trabalhos de Eugênio Vilaça Mendes ${ }^{131}$, principal referência no tema no Brasil (PEREIRA, 2009). Em 2012, a secretaria estadual de saúde e o Conselho de Secretários Municipais de Saúde, contando com a participação de técnicos do Ministério da Saúde, constituíram um grupo condutor para a elaboração dos Coaps regionais (TAVARES et al., 2013).

Já o estado de São Paulo, em 2011, atualizou sua regionalização considerando o processo de estruturação das redes regionalizadas de atenção à saúde (RRAS) no estado, agregando regiões de saúde segundo a conformação das redes (no limite da divisão político-administrativa dos Departamentos Regionais de Saúde - DRS), totalizando dez grandes regiões de gestão do $\operatorname{SUS}^{132}$. A partir de 2012, o estado de São Paulo iniciou a discussão sobre a elaboração dos Coap em suas regiões de saúde.

${ }^{131}$ MENDES, E. V. O plano estratégico da saúde em Minas Gerais. Apresentação em Power point realizada no âmbito do Projeto de Cooperação ENSP/SESDEC-RJ. Rio de Janeiro (RJ), 06 de agosto de 2008 (apud Pereira, 2009).

132 Fonte: Secretaria de Estado de Saúde de São Paulo. Mapa das RRAS disponível em: http://www.saude.sp.gov.br/ses/perfil/gestor/mapas-de-saude-2012/mapas-tematicos/condicoes- 
Esses dados confirmam os resultados da pesquisa de Viana \& Lima (2011), indicando que os contextos mais favoráveis, as institucionalidades mais avançadas e a governança coordenada e cooperativa deverão beneficiar a adesão dos estados à nova fase da regionalização contratualizada. Confirmam também o papel condicionante das situações geográficas que caracterizam as quatro grandes regiões brasileiras sobre o processo de regionalização do SUS, indicando maiores dificuldades de adesão à nova fase da regionalização contratualizada para os estados da Amazônia e do Nordeste. 


\section{Conclusões}

O governo federal exerce um forte papel indutor sobre as mudanças na política de saúde dos estados, inclusive, aquelas relacionadas à organização regional do sistema. Esse papel se fundamenta principalmente em bases financeiras (transferências de recursos para os entes e novos recursos condicionados ao cumprimento, assinatura ou execução de determinados projetos e planos), e, sobretudo no caso da regionalização, em bases normativas (diretrizes, portarias), muitas delas negociadas no âmbito da Comissão Intergestores Tripartite (CIT).

As Normas Operacionais Básicas - NOBs (década de 1990) garantiram que o SUS se concretizasse através da descentralização, além de criarem as comissões de negociação intergovernamentais. A Norma Operacional de Assistência à Saúde Noas (2001) deu início ao processo de regionalização nos estados, o Pacto pela Saúde (2006) deu novas possibilidades para os estados reorganizarem suas regiões de saúde, focando a negociação intergovernamental, e, finalmente, o Decreto 7.508 (2011) reformulou toda a estratégia de regionalização e seus instrumentos, induzindo, recentemente, novas mudanças nas políticas estaduais.

Em dez anos (2001-2011), o enfoque regional na política de saúde brasileira progrediu no sentido de tornar a região de saúde o recorte privilegiado para induzir mudanças técnicas e políticas no sistema e tornar mais eficaz a ação do Estado no processo de universalização da saúde em todo o território nacional.

Num primeiro momento, fase da "regionalização normativa" (2001), as diretrizes nacionais focaram a estruturação de regiões de saúde a partir de critérios de funcionamento e hierarquização das redes e fluxos assistenciais, sem que houvesse uma definição mais específica sobre o conceito e os instrumentos de planejamento e gestão da rede de saúde. O objetivo central foi superar a fragmentação do sistema resultante do processo de descentralização municipal e organizar redes e fluxos intermunicipais. 
Num segundo momento, fase da "regionalização viva" (2006), as diretrizes nacionais focaram a estruturação das regiões a partir dos acordos intergovernamentais, respeitando as decisões locais sobre os critérios a serem adotados para a regionalização e a conformação de redes de saúde, também sem definir conceitos e instrumentos para as redes. O objetivo central foi retomar o papel dos estados no planejamento, flexibilizar o desenho das regiões conforme as realidades locais e promover relações intergovernamentais mais cooperativas, criando instâncias colegiadas regionais, valorizando a participação de todos os entes federados nesse processo.

Em 2010, a publicação da Portaria 4.279 supriu uma importante lacuna do planejamento regional do SUS ao trazer diretrizes para a estruturação de redes de atenção à saúde. As redes atribuíram maior complexidade ao planejamento e gestão regional do SUS, ampliando a necessidade de negociação intergovernamental e investimentos em sistemas de informação para integrar as ações e serviços de saúde.

No terceiro e atual momento da "regionalização contratualizada" (2011), as diretrizes nacionais focaram a estruturação das regiões de saúde a partir de acordos intergovernamentais formalizados por meio de contratos (estabelecendo objetivos, responsabilidades físicas e financeiras e metas; assinado pelas três esferas de governo) e da conformação de redes de atenção à saúde (temáticas), estas sim baseadas em definições, critérios e instrumentos específicos de planejamento e financiamento. $\mathrm{O}$ objetivo central é dar maior segurança jurídica nas relações entre os gestores e concretude ao processo de regionalização, já que a região de saúde não é uma unidade de execução orçamentária e sua organização e funcionamento depende fundamentalmente de um acordo intergovernamental. O objetivo também é efetivar a integração de ações e serviços de saúde em redes temáticas ${ }^{133}$ a partir das regiões estabelecidas, focando a integralidade do acesso e a capacidade do Estado de responder às necessidades de saúde da população.

$\mathrm{Na}$ política nacional, do ponto de vista técnico-normativo, pode-se afirmar que a regionalização proposta para o SUS caminhou no sentido de criar regiões cooperativas, baseadas na solidariedade organizacional entre os lugares a partir da

\footnotetext{
${ }^{133}$ Rede Cegonha, Rede de Atenção às Urgências e Emergências; Rede de Atenção Psicossocial; Rede de Atenção às Doenças e Condições Crônicas; Rede de Cuidado à Pessoa com Deficiência.
} 
integração de redes e fluxos e da cooperação e coordenação intergovernamental. A região de saúde também tem uma perspectiva cooperativa na medida em que a garantia da integralidade do atendimento depende da solidariedade entre as regiões, como estratégia para enfrentar as desigualdades socioespaciais e garantir aos cidadãos o acesso a todos os serviços e ações ofertados pelo SUS no território nacional. A criação de Comissões Intergestores Regionais (CIR), a busca pela integralidade no atendimento ao cidadão, pela estruturação de redes de atenção à saúde e pela formalização dos contratos organizativos (Coap) contribuem fortemente nesse sentido.

A tendência de conformação de regiões cooperativas na política de saúde se contrapõe à crescente competitividade entre os lugares e regiões geográficas (guerra entre os lugares ${ }^{134}$, regiões ganhadoras $^{135}$, regiões competitivas $\left.{ }^{136}\right)$, incentivada pelas políticas de modernização e desenvolvimento econômico do território no período da globalização. Ao mesmo tempo, dialoga com a estratégia de ampliação das parcerias e da cooperação intergovernamental em torno da diminuição das desigualdades econômicas e sociais, adotada pelo Estado brasileiro no processo de retomada do planejamento regional, nos últimos dez anos, a partir da formulação de projetos mais inclusivos e de valorização dos ativos regionais (regiões-programa ${ }^{137}$ ).

Contudo, a construção de regiões cooperativas representa um enorme desafio diante da dimensão territorial da universalização da saúde no Brasil. A política de saúde e a concretização do SUS estão fortemente associadas ao processo de modernização do território, cuja lógica histórico-estrutural predominante é a da competitividade e reprodução das desigualdades, que resulta na grande concentração espacial de recursos, tecnologias, profissionais, usuários e fluxos materiais e imateriais nas capitais, metrópoles e nos polos regionais.

Nesse sentido, do ponto de vista geográfico, pode-se afirmar que a estruturação do sistema e das políticas nacionais de saúde no território ajuda a configurar regiões do mandar ${ }^{138}$ - que ditam os padrões de saúde, inovação,

\footnotetext{
${ }^{134}$ Santos, 1996.

135 Benko \& Lipietz, 1994.

${ }^{136}$ Castillo, 2008.

${ }^{137}$ BRASIL, MIN, 2012b.

${ }^{138}$ Este termo refere-se aqui às regiões geográficas do território brasileiro e não às regiões de saúde. Conforme definido por Milton Santos (1994b) em referência ao papel desempenhado por cada região
} 
qualidade, descentralização, acesso, planejamento, regionalização, investimento, concentração de serviços e universalização (a exemplo dos estados da Região Concentrada) - e regiões do fazer - que possuem menor capacidade de comando sobre a evolução do sistema nacional de saúde e executam, com dificuldade, as diretrizes inspiradas em padrões longínquos de sua realidade e possibilidade (a exemplo dos estados da Amazônia).

O aparato normativo da "regionalização contratualizada" do SUS e das redes temáticas de atenção à saúde exige ainda mais capacidade técnica-científicainformacional, financeira e política por parte das esferas governamentais para a execução das diretrizes e dos objetivos propostos.

A institucionalidade da regionalização contratualizada tende a ser mais avançada e sua governança mais cooperativa e coordenada nos estados com maior tradição de planejamento regional, com forte atuação técnica e política das secretarias estaduais e municipais de saúde (e/ou dos conselhos representantes destas secretarias) e onde a regionalização vem sendo priorizada nas agendas estaduais e municipais.

Ao mesmo tempo, a estruturação de redes temáticas de atenção à saúde e a organização regional contratualizada do SUS deverá ser favorecida nos estados mais populosos, onde a rede urbana for mais densa e extensa, onde houver maiores investimentos em infraestrutura de transporte e comunicação, especialmente em sistemas de informação nos serviços de saúde conectados em rede, e nos estados concentradores de tecnologias, profissionais, fluxos materiais e imateriais e recursos públicos e privados de saúde.

Os Contratos Organizativos de Ação Pública em Saúde (Coaps) e o Mapa de Saúde têm o potencial de informar a política de saúde sobre a divisão territorial do trabalho na assistência à saúde, isto é, sobre o papel de cada ente federado e de cada região de saúde na produção, integração e no acesso às ações, serviços e tecnologias ofertados pelo SUS. Contudo, ainda não está claro o potencial dos instrumentos da nova regionalização, especialmente dos Coaps, para enfrentar a desigualdade

geográfica na divisão internacional do trabalho. Regiões do mandar são aquelas que concentram empresas e instituições públicas e privadas com poder de comando sobre a produção, circulação e consumo de produtos e informações que se dão em outras regiões (do fazer). As regiões do fazer são aquelas onde se realizam parte da produção, da circulação e do consumo de produtos cuja lógica está sob o comando das regiões do mandar. 
territorial da universalização da saúde no Brasil, sobretudo no que diz respeito à concentração espacial da oferta de ações e serviços, investimentos, tecnologias, equipamentos e profissionais de saúde nos estados.

Da mesma forma, ainda não está clara a relação condicionante entre a assinatura dos Coaps e a estruturação das redes temáticas nas regiões de saúde. Os investimentos nos componentes das redes têm sido um importante instrumento de indução federal para a estruturação das mesmas nos estados, sem resultar, entretanto, na elaboração e assinatura dos Coaps. Entretanto, o recurso novo que entra nos estados através da política das redes, se não estiver associado aos objetivos do planejamento regional, poderá servir para atualizar a lógica da concentração da oferta de serviços, tecnologias e profissionais de saúde no território.

Observou-se que a estratégia de regionalização do SUS e de estruturação das redes de atenção à saúde nas regiões não enfrentam as relações entre Estado e Mercado, que permanecem no cerne do funcionamento do sistema de saúde brasileiro e, por vezes, são consideradas um fator limitante para avanços no fortalecimento da lógica pública, regional e universal de saúde.

Em todos os estados as relações entre Estado e Mercado incidem, de maneira mais ou menos acentuada, sobre a organização das regiões de saúde, ora limitando a desconcentração da oferta assistencial para regiões mais carentes (vazios assistenciais), ora pressionando por novos investimentos públicos nas regiões de expansão e concentração econômica. Trata-se de uma questão estrutural, cujo enfrentamento depende, dentre outras coisas, da indução do governo federal sobre o planejamento regional considerando os mecanismos dessa relação. Dificilmente os estados isoladamente irão conseguir, a partir de seus próprios meios e instrumentos, enfrentar os principais fatores limitantes e condicionantes da relação entre Estado e Mercado sobre as estratégias de regionalização do SUS.

Confirmou-se que a dimensão territorial da universalização da saúde impõe limitações à ação do Estado. As diversidades e desigualdades socioespaciais da universalização da saúde nos lugares associadas à organização política do território brasileiro criam diferentes entraves e possibilidades para o planejamento e gestão regional do SUS. 
Primeiro, a capacidade de atuação dos entes federados sobre o processo de conformação e organização regional do SUS é fortemente condicionada pelas situações geográficas e usos do território que caracterizam o país, as grandes regiões, os estados e os municípios. Segundo, é condicionada pelos contextos políticosinstitucionais e conjunturais da política de saúde, considerando a trajetória das políticas, das instituições e dos gestores nas três esferas de governo. Terceiro, nos lugares, o sistema e as políticas de saúde envolvem uma diversidade de atores e instituições, interesses e relações regionais, nacionais e internacionais, que dizem respeito à produção e difusão de tecnologias e conhecimento científico, à regulação e integração sistêmica das ações e serviços, à circulação de insumos e informações no sistema, à alocação de profissionais e estratégias de formação, à oferta de ações e serviços e aos fluxos assistenciais da população. Quarto, a lógica de funcionamento e integração das redes de atenção à saúde ultrapassam os limites das regiões de saúde e dos estados, envolvendo uma diversidade de atores, instituições públicas e privadas e interesses que não estão totalmente submetidos ao planejamento regional do sistema negociado pelas esferas governamentais nas comissões intergestores (regionais CIR, bipartite - CIB e tripartite - CIT).

A dimensão territorial condiciona regionalização do SUS por conta das desigualdades existentes tanto em relação à conformação do sistema, quanto à capacidade técnica, política e financeira dos entes federados para executarem as políticas propostas, sobretudo, quando elas exigem maior articulação, coordenação, cooperação e negociação intergovernamentais.

A superação das desigualdades estruturais de universalização da saúde depende de políticas articuladas em diversas escalas espaciais, inclusive macrorregionais. Nesse sentido, considerando o importante papel indutor das Comissões Intergestores Bipartite (CIB) para a regionalização do SUS e a tendência de fortalecimento das Comissões Intergestores Regionais (CIR) nesse processo nos estados, seria o caso, talvez, de se criar comissões meso (intra e interestaduais) e macrorregionais de negociação intergovernamental da política de saúde.

O trabalho aponta para a necessidade de elaboração sistemática de uma compreensão sobre a dimensão territorial da universalização da saúde no Brasil, nas três esferas de governo, segundo suas capacidades e competências. Destaca-se, 
entretanto, o papel estratégico do Ministério da Saúde na produção e organização de dados e análises estatísticas (salas de situação, bancos de dados nacionais, etc.), mas, sobretudo, na produção de uma inteligência territorial sobre os diversos condicionantes do processo da universalização da saúde - conformação do sistema e das políticas de saúde -, considerando distintas escalas temporais e espaciais (nacional, macro, meso, microrregionais, estaduais e municipais) e as situações geográficas que marcam o Brasil no período atual.

Trata-se de buscar compreender as razões histórico-estruturais e conjunturais das desigualdades regionais em saúde (do sistema e das políticas), mas, sobretudo, em que sentido essas desigualdades avançam, limitando ou possibilitando a ação de planejamento do Estado e a universalização da saúde.

Por fim, as análises empreendidas apontam para a necessidade de se estabelecer mais claramente a relação entre os instrumentos e mecanismos de estruturação, planejamento, financiamento e gestão das redes e das regiões de saúde. Considerando que as regiões de saúde não são apenas "o limite geográfico de abrangência das redes de atenção à saúde ou abrangência da base populacional atendida pelas redes"139. Tampouco se referem somente ao espaço geográfico contínuo constituído por agrupamentos de municípios limítrofes, cujos elementos principais de organização são a população usuária, os fluxos assistenciais, a rede de atenção à saúde, o rol mínimo de ações e serviços ofertado pelo SUS e a existência de uma Comissão Intergestores Regional ${ }^{140}$.

As regiões de saúde são recortes de planejamento da política de saúde que incidem sobre diferentes situações geográficas, econômicas, sociais e políticas, que condicionam a ação do Estado e a conformação do sistema. Envolvem ainda relações de poder entre diferentes atores e instituições que participam direta e indiretamente do funcionamento do sistema de saúde nos lugares, e entre diferentes entes federados, que são desiguais quanto aos usos do território que abrigam e quanto às condições técnicas, financeiras e políticas para a execução das normas e objetivos do planejamento regional do SUS.

\footnotetext{
${ }^{139}$ Portaria 4.279/2010.

${ }^{140}$ Decreto $7.508 / 2011$.
} 
A região de saúde tem um enfoque mais totalizador sobre a dimensão territorial da universalização da saúde e um objetivo mais amplo de diminuir as desigualdades socioespaciais. Já as redes de atenção à saúde também objetivam a redução das desigualdades, mas focam especificamente a integração entre ações e serviços de forma a garantir a integralidade no atendimento, segundo linhas de cuidado específicas.

Por um lado, as redes estruturam regiões, conferido racionalidade à solidariedade organizacional entre os lugares que compartilham determinada oferta e demanda de ações e serviços de saúde. Nesse sentido, a definição tardia das diretrizes das redes de atenção à saúde criou limitações para o avanço do planejamento regional do SUS. Por outro lado, as regiões de saúde abrigam ofertas e demandas de serviços nem sempre contemplados pelas redes de atenção à saúde e suas linhas de cuidado.

Essas três estratégias devem estar muito bem articuladas no planejamento do sistema de saúde: a descentralização, a regionalização e a estruturação de redes de atenção à saúde. As redes e fluxos assistenciais podem ultrapassar os limites das regiões de saúde, mas estas permanecem como sendo os espaços privilegiados para a integração entre os diversos nós das redes de saúde e entre os planos e políticas de saúde; para o estabelecimento de relações intergovernamentais mais cooperativas e coordenadas; e para a ampliação da participação dos atores envolvidos e interessados no planejamento do sistema, visando garantir a universalização da saúde. 


\section{Referências}

ABLAS, Luiz. O "Estudo dos Eixos" como instrumento de planejamento regional. In: GONÇALVES MF, BRANDÃO CA, GALVÃO ACF (orgs.). Regiões e cidades, cidades nas regiões: o desafio urbano-regional. São Paulo: Editora Unesp: Anpur, 2003, p.171-186.

ABRUCIO, F. L. A coordenação federativa no Brasil: a experiência do período FHC e os desafios do Governo Lula. Rev. Sociol. Polít., Curitiba, 24, p. 41-67, jun. 2005.

ALBUQUERQUE, M. V. de. Lugar e Saúde: respostas do Sistema Único de Saúde à situação de metropolização em Campinas - SP. In: SOUZA, Maria Adélia A. de. A Metrópole e o Futuro: refletindo sobre Campinas. Campinas-SP: Edições Territorial, 2008. p.527-550.

ALBUQUERQUE, M.V. de A. Território Usado e Saúde: respostas do Sistema Único de Saúde à situação de metropolização em Campinas - SP. Dissertação. Departamento de Geografia, Faculdade de Filosofia, Letras e Ciências Humanas, Universidade de São Paulo, São Paulo, 2006.

ALBUQUERQUE, Mariana Vercesi de. Política Nacional de CT\&I em saúde e a regionalização do SUS: diálogos possíveis. In: Viana ALd'Á, Lima LD, Ibañez N, Bousquat A (orgs.). Saúde, desenvolvimento, ciência, tecnologia e inovação. São Paulo: Hucitec; Cealag, 2012, p. 174-202.

ALBUQUERQUE, Mariana Vercesi de; MELLO, Guilherme Arantes; IOZZI, Fabíola Lana. "O processo de regionalização em saúde nos estados brasileiros". In: VIANA, Ana Luiza d'Ávila; LIMA, Luciana Dias de. Regionalização e relações federativas na política de saúde do Brasil. Rio de Janeiro: Contra Capa, (p.117-172), 2011.

ALMEIDA, Eliza P. de. Uso do Território Brasileiro e os Serviços de Saúde no Período Técnico-Científico-Informacional. Tese. Faculdade de Filosofia Ciências e Letras FFLCH/USP, 2005.

ALMEIDA, M. H. T. O Estado Brasil contemporâneo - um passeio pela história. In: MELO, C.R.; SÁEZ, M.A. (orgs.). A democracia Brasileira. $1^{a}$ ed. Belo Horizonte: Editora UFMG, 2007, v. 1, p. 17-38.

ANDRADE, Manuel Correia de. Espaço, polarização e desenvolvimento. São Paulo, Brasiliense, 1973.

ANDRADE, Rômulo de Paula Andrade. A Amazônia vai ressurgir! Saúde e saneamento na Amazônia no primeiro governo Vargas. [Dissertação] Casa de Oswaldo Cruz, Fiocruz, Rio de Janeiro, 2007.

ARAÚJO, Herton Ellery. "Desigualdades, mudanças demográficas recentes e perfil epidemiológico como variáveis políticas de saúde - uma análise regional". In: NEGRI, Barjas e DI GIOVANNI, Geraldo. Brasil: radiografia da saúde. Campinas, SP: UNICAMP. IE, 2001. pp. 515-528.

ARAÚJO, José Duarte de et al. Regionalização dos serviços de saúde pública: a experiência do Estado da Bahia, Brasil. Revista de Saúde Pública, São Paulo, 7: 1-19, 1973

ARAÚJO, José Duarte de. Saúde e desenvolvimento econômico: atualização de um tema. Rev. Saúde Pública, Dez 1975, vol.9, no.4, p.515-528.

ARAÚJO, Tânia Bacelar. A "questão regional" e a "questão nordestina". In: TAVARES, Maria da Conceição (org.). Celso Furtado e o Brasil. São Paulo: Fundação Perseu Abramo. 2001, p.71-92. 
ARAÚJO, Tânia Bacelar. Desenvolvimento Regional no Brasil. Palestra proferida no IE/Unicamp em 30/05/2012.

ARAÚJO, Tânia Bacelar. Dinâmica regional brasileira nos anos noventa: rumo à desintegração competitiva? In: CASTRO IE; MIRANDA M; EGLER CAG (orgs.). Redescobrindo o Brasil: 500 anos depois. Rio de Janeiro: Bertrand Brasil, 2000, p.7389.

ARRETCHE, Marta. Federalismo e igualdade territorial: uma contradição em termos? Dados - Revista de Ciências Sociais, Rio de Janeiro, vol. 53, no 3, 2010, pp. 587 a 620.

ASSIS, Emerson et al. Regionalização e novos rumos para o SUS: a experiência de um colegiado regional. Saude soc. 2009, vol.18, suppl.1, pp. 17-21.

BAHIA, L. O SUS e os desafios da universalização do direito à saúde: tensões e padrões de convivência entre o público e o privado no sistema de saúde brasileiro. In: LIMA, N.T. et. al. (org). Saúde e Democracia: história e perspectivas do SUS. Rio de Janeiro: FIOCRUZ, 2005. p.407-450.

BANCO MUNDIAL. MS. Projeto de Investimento para a Qualificação do Sistema Único de Saúde (QualiSUS-Rede). Maio de 2008. Disponível em: http://portal.saude.gov.br/portal/saude/visualizar_texto.cfm?idtxt=28282 e http://web.worldbank.org/external/projects/main?pagePK=64283627\&piPK=73230\&th eSitePK=40941\&menuPK=228424\&Projectid=P088716. Acesso em 08/12/08.

BAPTISTA, Tatiana WF, GOMES, Márica MG e NOGUEIRA, Carolina de O. O Legislativo e a Saúde: o debate no período do governo Lula. In: MACHADO, Cristiani V., BAPTISTA, Tatiana Wargas de Faria, LIMA, Luciana Dias de (orgs.). Políticas de saúde no Brasil: continuidades e mudanças. Rio de Janeiro: Editora Fiocruz, 2012, p.283-321.

BAPTISTA, Tatiana WF; GARCIA, Márcia; LIMA, Luciana D; MACHADO, Cristiani V; ANDRADE, Carla LTA. O orçamento federal e as emendas parlamentares da saúde no PPA 2004-2007: uma discussão a partir das regras institucionais. In: MELAMED, Clarice; PIOLA, Sério F. Políticas públicas e financiamento federal do Sistema Único de Saúde. Brasília: Ipea, 2011, p.287-316.

BASTOS, N. C. B. SESP-FSESP: 1942 - evolução histórica - 1991. Brasília, DF: Fundação Nacional de Saúde, 1996.

BECKER, B. K. e EGLER, C. Brasil: uma nova potência mundial na economia-mundo. Rio de Janeiro: Bertrand Brasil, 2003, $4^{\text {a }}$ ed. ( $1^{\text {a }}$ ed. 1992).

BECKER, B.K. (2003). Amazônia: mudanças estruturais e urbanização. En M.F Gonçalves, C. Brandão y A.C. Galvão (Eds.). Regiões e cidades, cidades nas regiões: o desafio urbano-regional. São Paulo: editora da UNESP, ANPUR.

BECKER, B.K. et al. Amazônia: desenvolvimento e soberania. In: Rezende, F \& Tafner P, editores. Brasil: O estado de uma nação. Rio de Janeiro: Ipea, 2005.

BECKER, Bertha K. Síntese das contribuições da oficina da Política Nacional de Ordenamento Territorial. MINISTÉRIO DA INTEGRAÇÃO NACIONAL. Secretaria de Políticas de Desenvolvimento Regional. Para pensar uma política nacional de ordenamento territorial: anais da Oficina sobre a Política Nacional de Ordenamento Territorial, Brasília, 13-14 de novembro de 2003. Brasília: MIN, 2005, p.71-78.

BELENES, R. Un balance personal de 25 años de gestión sanitaria moderna en el Sistema Nacional de Salud. Gac Sanit 2003;17(2):150-6.

BENCHIMOL, J. L. Manguinhos do sonho a vida: a ciência na Belle Epoque. Rio de Janeiro: Fundação Oswaldo Cruz, 1990a.

BENCHIMOL, J. L. Pereira Passos: um Haussman tropical. Rio de Janeiro: Secretaria Municipal da Cultura, Turismo e Esporte, 1990b. (Coleção Biblioteca Carioca).

BENKO, Georges; LIPIETZ, Alain (orgs.). As regiões ganhadoras. Distritos e Redes: os novos paradigmas da Geografia Econômica. Oieras: Celta Editora, 1994.

BERNARDES, Adriana. A contemporaneidade de São Paulo: produção de informações e novo uso do território brasileiro. Tese de Doutorado, Departamento de Geografia, 
Faculdade de Filosofia, Letras e Ciências Humanas, Universidade de São Paulo, 2001, $283 \mathrm{p}$.

BIELSCHOWSKY, Ricardo. Pensamento econômico brasileiro: o ciclo ideológico do desenvolvimentismo (1930 - 1964). Rio de Janeiro: Contraponto, 2000.

BOISIER, Sergio. Desarrollo (local): ? de qué estamos hablando? In: Madoery, Oscar y Vázquez Barquero, Antonio (eds.), Transformaciones globales, Instituciones y Políticas de desarrollo local. Editorial Homo Sapiens, Rosario, 2001.

BONFIM, José Ruben de Alcântara. Presentation. Rev. bras. epidemiol. 1998, vol.1, n.3, pp. 298-302.

BOUDEVILLE, Jacques R. Desenvolvimento polarizado e planejamento regional. Boletim de Geografia, Rio de Janeiro, 32(237): 5-15, nov./dez., 1973.

BRAGA, José Carlos de Souza \& PAULA, Sergio Góes de. Saúde e Previdência: estudos de política social. São Paulo: Cebes / Hucitec, 1981.

BRANDÃO, C. Território e desenvolvimento: as múltiplas escalas entre o local e o global. Campinas: Editora da Unicamp, 2007.

BRASIL, Ministério da Saúde. Colegiado de Gestão Regional na região de saúde intraestadual: orientações para organização e funcionamento. (Série Pactos pela Saúde, v.10). Brasília: Ministério da Saúde, 2009.

BRASIL, Ministério da Saúde. Conselho Nacional de Saúde. Manual de implantação de complexos reguladores. Brasília: Ministério da Saúde, 2006c.

BRASIL, Ministério da Saúde. Regionalização solidária e cooperativa: orientações para sua implementação no SUS. (Série Pactos pela Saúde, v.3). Brasília: Ministério da Saúde, 2006.

BRASIL, Ministério da Saúde. Secretaria de Atenção à Saúde. Diretrizes para a Programação Pactuada e Integrada da Assistência à Saúde. Brasília: Ministério da Saúde, 2006b.

BRASIL. Constituição Federal. 1937.

BRASIL. Constituição Federal. 1988.

BRASIL. Decreto ${ }^{\circ} 7.508$, de 28 de junho de 2011. Regulamenta a Lei $n^{\circ} 8.080$, de 19 de setembro de 1990, para dispor sobre a organização do Sistema Único de Saúde - SUS, o planejamento da saúde, a assistência à saúde e a articulação interfederativa, e dá outras providências. Diário Oficial da União 2011, 29 jun.

BRASIL. Instituto Brasileiro de Geografia e Estatística. Divisão regional do Brasil em mesorregiões e microrregiões geográficas. Rio de Janeiro: IBGE, 1990.

BRASIL. Lei Orgânica da Saúde - Lei n. 8080 de 19 set. 1990. Dispõe sobre as condições para a promoção, proteção e recuperação da saúde, a organização e o funcionamento dos serviços correspondentes e dá outras providências. Diário Oficial da União 1990, 20 set.

BRASIL. Ministério da Ciência e Tecnologia. Plano de Ação 2007-2010. Ciência, Tecnologia e Inovação para o Desenvolvimento Nacional. Brasília: MCT; 2007a.

BRASIL. Ministério da Ciência, Tecnologia e Inovação. Estratégia nacional de Ciência, Tecnologia e Inovação (2012-2015): balanço das atividades estruturantes (2011). Brasília, DF: 2012a.

BRASIL. Ministério da Integração Nacional. Desigualdades regionais e critérios de elegibilidade. Apresentação de Pedro Luiz Cavalcante, Secretaria de Desenvolvimento Regional. I Conferência Nacional de Desenvolvimento Regional. 2012a. Disponível em: www.integracao.gov.br.

BRASIL. Ministério da Integração Nacional. Documento base para a definição da Política Nacional de Ordenação do Território - PNOT (Versão preliminar). Brasília: Ministério da Integração Nacional, 2006.

BRASIL. Ministério da Integração Nacional. Política Nacional de Desenvolvimento Regional. Sumário Executivo. Brasília, DF: Ministério da Integração Nacional, 2007. 
BRASIL. Ministério da Integração Nacional. Política Nacional de Desenvolvimento Regional. Apresentação do Secretário de Desenvolvimento Regional Sergio Duarte de Castro. I Conferência Nacional de Desenvolvimento Regional. Conferência Macrorregional de Desenvolvimento Regional da Região Sul. 2012b. Disponível em: www.integracao.gov.br.

BRASIL. Ministério da Integração Nacional. Programa de Promoção da Sustentabilidade de Espaços Sub-Regionais - Promeso. Brasília, DF: Ministério da Integração Nacional, 2009.

BRASIL. Ministério da Integração Nacional. Secretaria de Políticas de Desenvolvimento Regional. Para pensar uma política nacional de ordenamento territorial: anais da Oficina sobre a Política Nacional de Ordenamento Territorial, Brasília, 13-14 de novembro de 2003. Brasília: MI, 2005.

BRASIL. Ministério da Integração Nacional. Secretaria de Políticas de Desenvolvimento Regional. A PNDR em dois tempos: A experiência apreendida e o olhar pós 2010. Brasília, DF: 2010.

BRASIL. Ministério da Integração Nacional. Secretaria de Programas Regionais. Proposta de Reestruturação do Programa de Desenvolvimento da Faixa de Fronteira/Ministério da Integração Nacional. Brasília: Ministério da Integração Nacional, 2005b.

BRASIL. Ministério da Saúde. A Regionalização da Saúde (Versão preliminar para discussão interna). Brasília: jun. 2004.

BRASIL. Ministério da Saúde. Discurso pronunciado pelo Ministro de Estado da Saúde, Deputado Wilson Fadul. III Conferência Nacional de Saúde. Rio de Janeiro - RJ, 9 a 15 de dezembro de 1963 (http://bvsms.saude.gov.br/bvs/pacsaude/conferencias.php).

BRASIL. MINISTÉRIO DA SAÚDE. Discurso pronunciado pelo Ministro de Estado da Saúde, Roberto Figueira Santos. VIII Conferência Nacional de Saúde. Brasília - DF, 17 a 21 de março de 1986 (http://bvsms.saude.gov.br/bvs/pacsaude/conferencias.php).

BRASIL. Ministério da Saúde. Discurso pronunciado pelo Ministro de Estado da Saúde, José Gomes Temporão. XIII Conferência Nacional de Saúde. Brasília - DF, 14 a 18 de novembro de 2007. Disponível em: http://www.ensp.fiocruz.br/biblioteca/home/exibedetalhesBiblioteca.cfm?ID=4774\&Tip $\mathrm{O}=\mathrm{B}$.

BRASIL. Ministério da Saúde. Portaria MS/GM n. 95, de 26 jan. 2001. Aprova a norma operacional da assistência à saúde - NOAS-SUS 01/01. Diário Oficial da União, Brasília, 26 jan. 2001.

BRASIL. Ministério da Saúde. Portaria $n^{\circ} 2.203$, de 5 de novembro de 1996. Aprova a Norma operacional Básica - NOB 1/96 do Sistema Único de Saúde (SUS). Diário Oficial da União, Brasília, 6 nov. 1996.

BRASIL. Ministério da Saúde. Programa Mais Saúde: Direito de Todo. 2008-2011. Brasília: MS; dez 2007.

BRASIL. Ministério da Saúde. Secretaria de Assistência à Saúde. Departamento de Descentralização da Gestão da Assistência. Regionalização da Assistência à Saúde: aprofundando a descentralização com eqüidade no último acesso. Brasília: Ministério da Saúde, 2002. (Norma Operacional da Assistência à Saúde: NOAS-SUS 01/02 e Portaria MS/GM n. 373, de 27 fev. 2002 e regulamentação complementar).

BRASIL. Ministério da Saúde. Secretaria de Atenção à Saúde. Departamento de Atenção Básica. Política Nacional de Atenção Básica. Brasília, DF: Ministério da Saúde, 2012e.

BRASIL. Ministério da Saúde. Secretaria de Atenção à Saúde. Diretoria de Articulação de Redes de Atenção à Saúde. Redes regionalizadas de Atenção à Saúde: contexto, premissas, diretrizes gerais, agenda tripartite para discussão e proposta de metodologia para apoio à implementação. Documento Base. Brasília: MS, novembro de 2008d.

BRASIL. Ministério da Saúde. Secretaria de Ciência, Tecnologia e Insumos Estratégicos. As ações de CTI em Saúde nos Sistemas Estaduais: PPSUS 2012. Fórum Nacional: 
CONSECTI-CONFAP. Curitiba: 08 e 09 de março de 2012. Disponível em: www.confap.org.br/palestra/14hs_carlos_gadelha.ppt, acesso em junho de 2012b.

BRASIL. Ministério da Saúde. Secretaria de Gestão Estratégica e Participativa. Minuta do Contrato Organizativo da Ação Pública da Saúde. Brasília, DF: Ministério da Saúde, 2011c.

BRASIL. Ministério da Saúde. Secretaria de Gestão Estratégica e Participativa. Metas e indicadores para composição da parte II do Contrato Organizativo da Ação Pública da Saúde (Caderno). Brasília, DF: Ministério da Saúde, 2012.

BRASIL. Ministério da Saúde. Secretaria Executiva. Plano de Qualificação da Atenção à Saúde na Amazônia Legal - Saúde Amazônia. Brasília: Ministério da Saúde, 2005.

BRASIL. Ministério da Saúde. Secretaria-Executiva. Departamento de Apoio à Descentralização. Regionalização solidária e cooperativa: orientações para sua implementação no SUS. Brasília: 2006b.

BRASIL. Ministério da Saúde. Secretaria-Executiva. Departamento de economia da saúde, investimentos e desenvolvimento. Projeto de Formação e Melhoria da Qualidade da Rede de Saúde - QualiSUS-Rede. Informe Comissão Intergestores Tripartite (CIT). Brasília-DF: Ministério da Saúde, CIT (pautas e resumos), julho de 2012f. Disponível em: http://portal.saude.gov.br/portal/arquivos/pdf/4c1_260712.pdf. Acesso em abril de 2013.

BRASIL. Ministério da Saúde. Secretaria-Executiva. Subsecretaria de Planejamento e Orçamento. Plano Nacional de Saúde - PNS: 2012-2015 / Ministério da Saúde. Secretaria-Executiva. Subsecretaria de Planejamento e Orçamento. - Brasília: Ministério da Saúde, 2011.

BRASIL. Ministério do Planejamento, Orçamento e Gestão. Secretaria de Planejamento e Investimentos Estratégicos. Plano plurianual 2012-2015: projeto de lei. Brasília-DF: MP, 2011.

BRASIL. Portaria GM/MS n.4279 de 30 de dezembro de 2010. Estabelece diretrizes para a organização da Rede de Atenção à Saúde no âmbito do Sistema Único de Saúde. Diário Oficial da União 2010, 30 dez.

BRASIL. Portaria GM/MS n.699 de 30 de março de 2006. Regulamenta as diretrizes operacionais dos Pactos pela Vida e de Gestão. Diário Oficial da União 2006 (b), 03 abr.

BRASIL. Senado Federal. LEI No 1.102, de 18 de maio de 1950: Aprova o Plano SALTE e dispõe sôbre sua execução. Disponível em: http://www6.senado.gov.br/legislacao/ListaPublicacoes.action?id=107249. Acesso em: 17/04/2008.

BRASIL. Senado Federal. Mensagem no 180 de 16 de setembro de 2009. Autoriza a contratação de operação de crédito externo no âmbito do Projeto de Investimento para a Qualificação do Sistema Único de Saúde - QualiSUS Rede (fase 1).

BRITO, Paulo. Economia Brasileira: Planos Econômicos e Políticas Econômicas Básicas. São Paulo: ed. Atlas. 2004 ( $2^{\text {a }}$ ed.).

CAMPOS, AL. Políticas internacionais de saúde na Era Vargas: o Serviço especial de saúde pública, 1942-1960. Rio de Janeiro: Fiocruz, 2006.

CAMPOS, GW. Efeitos paradoxais da descentralização do Sistema Único de Saúde do Brasil. In: FLEURY, S. (org.). Democracia, descentralização e desenvolvimento: Brasil e Espanha. Rio de Janeiro: FGV, 2006. p. 417-442.

CAMPOS, GWS. Efeitos paradoxais da descentralização do Sistema Único de Saúde do Brasil. In: Fleury, S. (Org.). Democracia, descentralização e desenvolvimento: Brasil e Espanha. Rio de Janeiro: FGV, 2006.

CANO, Wilson. "Celso Furtado e a questão regional no Brasil". In: TAVARES, Maria da Conceição (org.). Celso Furtado e o Brasil. São Paulo: Editora Fundação Perseu Abramo, 2000 (1ª reimpressão, 2001), pp. 93-120. 
CARVALHEIRO, José da Rocha. Epidemias em escala mundial e no Brasil. Estud. av. 2008, vol.22, n.64, pp. 7-17 .

CARVAlHO, G. Regulamentação da Lei 8080: Um Decreto com 20 Anos de Atraso. Publicado em: 30/06/2011, Disponível em: $<$ http://www.cebes.org.br/internaEditoria.asp?idConteudo=1422\&idSubCategoria=30>. Acesso em março de 2012.

CARVALHO, Marília Sá, PINA, Maria de Fátima e SANTOS, Simone Maria dos. Conceitos básicos de Sistemas de Informação Geográfica e Cartografia aplicados à saúde. Brasília: Organização Panamericana da Saúde/Ministério da Saúde, 2000.

CASTELLS, Manuel. A sociedade em rede. São Paulo: Paz e Terra, 1999.

CASTILLO, Ricardo. Região competitiva e logística: expressões geográficas da produção e da circulação no período atual. Anais do IV Seminário Internacional sobre Desenvolvimento Regional. De 22 a 24 de outubro de 2008, Universidade de Santa Cruz do Sul - Unisc, RS, Brasil.

CASTILLO, Ricardo; TOLEDO JR, Rubens de; ANDRADE, Júlia. Três dimensões da solidariedade em geografia. Revista Experimental, Depto de Geografia/FFLCH/USP, ano II, $\mathrm{n}^{\mathbf{0}}$ 3, setembro de 1997, p.69-100.

CASTRO SANTOS, L. A. de. A fundação Rockefeller e o estado nacional: história e política de uma missão médica e sanitária no Brasil. Revista Brasileira de Estudos da População, 6 (1): 105-110, jan-jun, 1989.

CASTRO SANTOS, L. A. de. O pensamento sanitarista na Primeira República: uma ideologia de construção da nacionalidade. Dados - Revista de Ciências Sociais, 28: 193-210, 1985.

CASTRO SANTOS, L. A. de. Power, ideology and Public Health in Brazil (1889-1930), Tese de Doutorado, Cambridge: Havard University, 1987.

CASTRO, Ana Luisa Barros de., MACHADO, Cristiani Vieira. A política federal de atenção básica à saúde no Brasil nos anos 2000. Physis. 2012, vol.22, n.2, pp. 477-506.

CASTRO, Josué. Geografia da fome. São Paulo: Brasiliense, v.1, 1961 ( $7^{\text {a }}$ ed.).

CATAIA, Márcio A. Territorialidade estatal e outras territorialidades: novas formas de uso dos territórios na América Latina. Conflitos, desafios e alternativas. Scripta Nova. Revista Electrónica de Geografía y Ciencias Sociales, v. XII, p. 270/99, 2008.

CATAIA, Márcio A. Território Nacional e Fronteiras Internas. A Fragmentação do Território Brasileiro. Tese. São Paulo: USP/FFLCH, 2001.

CATAIA, Márcio A. Uso do território e federação: novos agentes e novos lugares. Diálogos possíveis e participação política. Scripta Nova. Revista Electrónica de Geografía y Ciencias Sociales, vol. XIV, no 331 (16), 2010.

CHORNY, A., 1998. Planificación en salud: Viejas ideas en nuevos ropajes. Cuadernos Médico Sociales (Rosario), 73:5-30.

CHORNY, Adolfo H. Planificación en Salud: viejas ideas em nuevos ropajes. Cuadernos médico sociales, Argentina, 73: 23-44, maio, 1998.

CHRISTALLER, W. 1933. Central places in southern Germany. London: Prentice Hall, 1966.

COELHO, Ana Paula S. O público e o privado na regionalização da saúde: processo decisório e condução da política no Estado do Espírito Santo [dissertação]. Escola Nacional de Saúde Pública, Fundação Oswaldo Cruz. Rio de Janeiro, 2011.

COHN, Amélia. Crise regional e planejamento. São Paulo: Perspectiva, 1978.

COHN, Amélia. O SUS e o Direito à saúde: universalização e focalização nas políticas de saúde. In: LIMA, Nísia Trindade (org.). Saúde e Democracia: história e perspectivas do SUS. Rio de Janeiro: Editora FIOCRUZ, 2005. p. 385 - 405.

CONASEMS (Conselho Nacional de Secretários Municipais de Saúde). CONASEMS: garantindo saúde nos municípios. Brasília: Ministério da Saúde, 2005.

CONASEMS. MAGALHÃES JR, Helvécio Miranda (presidente do Conasems). "Prefácio". In: SILVA, Silvio Fernandes da (org.). Redes de Atenção à Saúde no SUS: o pacto pela 
saúde e redes regionalizadas de ações e serviços de saúde. Campinas, SP: IDISA: CONASEMS, 2008. (p.7-10).

CONTANDRIOPOULOS A-P, DENIS J-L, TOUATI N, RODRIGUEZ R. Intégration des soins: dimensions et mise-en-oeuvre. Ruptures, revue transdiciplinaire em santé, vol.8, $\mathrm{n}^{\circ} 2,2001, \mathrm{p} .38-52$.

CORDEIRO, Hésio. A indústria da saúde no Brasil. Rio de Janeiro: Graal, $2^{a}$ edição, 1985.

CORRÊA, Roberto L. Região e organização espacial. São Paulo: Ática, 2007.

CORRÊA, Roberto L. Trajetórias Geográficas. Rio de Janeiro: Bertrand Brasil, 1997.

CORTES, Soraya Vargas. Sistema Único de Saúde: espaços decisórios e a arena política de saúde. Cad. Saúde Pública. 2009, vol.25, n.7, pp. 1626-1633.

COSTA, Nilson Rosário da. "A descentralização do sistema público de saúde no Brasil: balanço e perspectiva". In: NEGRI, Barjas e DI GIOVANNI, Geraldo. Brasil: radiografia da saúde. Campinas, SP: UNICAMP. IE, 2001. pp. 307-321.

COSTA, Wanderley Messias da. O Estado e as políticas territorial no Brasil. São Paulo: Contexto, 1988.

COSTA, Wanderley Messias da. Subsídios para uma Política Nacional de Ordenamento Territorial. MINISTÉRIO DA INTEGRAÇÃO NACIONAL. Secretaria de Políticas de Desenvolvimento Regional. Para pensar uma política nacional de ordenamento territorial: anais da Oficina sobre a Política Nacional de Ordenamento Territorial, Brasília, 13-14 de novembro de 2003. Brasília: MIN, 2005, p.55-60.

COUTO e SILVA, Golbery. Geopolítica do poder. Rio de Janeiro: UniverCidade, 2003.

DEFARGES PM. La Gouvernance. Paris: PUF; 2008.

DENIS, J-L. et al. Reforme et gouvernance en santé: l'attrait pour un managérialization de l'action publique. In: Guy Rocher, Pierre Noreau, Pascale Laborier, Marc Rioux (dir.). Reforme en santé et en justice: le droit et la governance. Montréal: Les Presses de L'Université Laval. 2008.

DIAS, Leila Cristina. "Os sentidos da rede: nota para discussão". In: DIAS, Leila Cristina e SILVEIRA, Rogério Leandro Lima da. Redes, Sociedades e Territórios. Santa Cruz do Sul: EDUNISC, 2007, p.11-28. (2 $2^{\text {a }}$.).

DINIZ, C.C. A questão regional e as políticas governamentais no Brasil. Texto para dicussão $\mathrm{n}^{\circ}$ 59. Belo Horizonte: CEDEPLAR/FACE/UFMG, 2001.

DOURADO, Daniel de Araujo and ELIAS, Paulo Eduardo Mangeon. Regionalização e dinâmica política do federalismo sanitário brasileiro. Rev. Saúde Pública. 2011, vol.45, n.1

DUARTE, Ligia S; CONTEL, Fabio B; BALBIM, Renato. Regionalização da saúde e ordenamento territorial: análises exploratórias de convergências. Brasil em Desenvolvimento. IPEA, Brasília-SF, 2013 (prelo).

ELIAS, Paulo E. M. "Estrutura e organização da atenção à saúde no Brasil". In: COHN, Amélia; ELIAS, Paulo E. M. Saúde no Brasil: políticas e organização de serviços. 4 ed. rev. ampl. São Paulo: Cortez: Cedec, 2001. p. 59-133.

ELIAS, Paulo Eduardo, MARQUES, Rosa Maria e MENDES, Áquilas. O financiamento e a política de saúde. Revista USP, São Paulo, nº51, pp.16-27, set/nov., 2001.

ERBER, Fábio. As convenções de desenvolvimento no governo Lula: um ensaio de economia política. Revista de Economia Política, vol. 31, nº 1 (121), pp. 31-55, janeiromarço/2011.

ESCOLA NACIONAL DE SAÚDE PÚBLICA. Projeto de Cooperação ENSP/SESDEC-RJ: Desenvolvimento de Metodologias de Planejamento Regional para Constituição de Redes de Atenção e Apoio à Implantação de Instâncias Intergovernamentais de Gestão em Saúde no âmbito Regional. Análise de experiências estaduais em curso de regionalização e construção de redes de serviços de saúde. Relatório Parcial. Rio de Janeiro-RJ, outubro de 2008.

ESPING-ANDERSEN, G. O futuro do Welfare State na nova ordem mundial. Revista Lua Nova, São Paulo, n. 35, 1995. 
EVANS, Peter. A Tríplice Aliança: as multinacionais, as estatais e o capitalismo nacional no desenvolvimento dependente brasileiro. Rio de Janeiro: Zahar, 1982, $2^{\mathrm{a}}$ ed. (1 $\left.{ }^{\mathrm{a} e d .,} 1979\right)$.

EVANS, Peter. Construção do Estado desenvolvimentista do século XXI: possibilidades e armadilhas. In: Viana ALd'Á, Lima LD, Ibañez N, Bousquat A (orgs.). Saúde, desenvolvimento, ciência, tecnologia e inovação. São Paulo: Hucitec-Cealag, 2012, p.35-64.

FAPESP. Fundação Rockfeller. Um país se faz com homens, saúde e doenças. Entrevista com Gilberto Hochman. Revista Fapesp, 198, agosto de 2012. Disponível em: http://revistapesquisa.fapesp.br/wp-content/uploads/2012/08/19_rockefeller_198.pdf

FARIAS, Hélio C \& SILVA BERNARDES, Adriana M. O BNDES e as empresas de consultoria na reorganização do território brasileiro na década de 1990. REDES, Santa Cruz do Sul, v. 13, n. 3, p. 99 - 120, set/dez. 2008.

FERREIRA, Maria Paula; DINI, Nádia P. Tipologia nacional dos colegiados de gestão regional. In: VIANA, Ana Luiza d'Ávila; LIMA, Luciana Dias de. Regionalização e relações federativas na política de saúde do Brasil. Rio de Janeiro: Contra Capa, (p.6780), 2011.

FIORI, José Luis. "Transição terminada: crise superada?". In Novos Estudos CEBRAP, n. ${ }^{\circ} 28$, outubro de 1990, p.144

FLEURY, Sonia e OUVERNEY, Assis Mafort. Gestão de Redes: a estratégia de regionalização da política de saúde. Rio de Janeiro: FGV, 2007.

FONSECA, C. Saúde no Governo Vargas (1930-1945): dualidade institucional de um bem público. Rio de Janeiro: Fiocruz, 2007.

FREDERICO, S. O Novo Tempo do Cerrado: Expansão dos Fronts Agrícolas e Controle do Sistema de Armazenamento de Grãos. 1. ed. São Paulo: AnnaBlume, 2010. v. 1. 259p.

FRIEDMANN, J. and BLOCH, R. American exceptionalism in regional planning, 19332000. International Journal of Urban and Regional Research, 14: 576-601, 1990.

FUJITA, Masahisa; KRUGMAN, Paul. The new economic geography: Past, present and the future. Papers Reg. Sci. 83, 139-164, 2004.

FURTADO, Celso. Discurso do professor Celso Furtado na cerimônia de criação da nova Sudene, em 28 de julho de 2003. Fortaleza-CE, 28/07/2003. Disponível em: http://www.integracao.gov.br/comunicacao/index.asp?area=pronunciamento_06. Acesso em fevereiro de 2011.

FURTADO, Celso. Formação Econômica do Brasil, 1959

FURTADO, Celso. Introdução ao desenvolvimento: enfoque histórico-estrutural. Rio de Janeiro: Paz e Terra, 2000. $3^{\text {a }}$ edição.

FURTADO, Celso. O Longo Amanhecer: reflexões sobre a formação do Brasil. Rio de Janeiro: Paz e Terra, 1999. (2 ${ }^{\mathrm{a}}$ ed.).

GADELHA, C.A.G. et al. Saúde e desenvolvimento: uma perspectiva territorial. In: Viana, A. L. D.; ELIAS, P. E. M. \& Ibañez, N. (orgs.). Saúde, desenvolvimento e território. São Paulo: Hucitec, 2009 (p.97-126).

GADELHA, Carlos Augusto Grabois; COSTA, Laís Silveira. Saúde e desenvolvimento no Brasil: avanços e desafios. Rev. Saúde Pública, São Paulo, 2012.

GADELHA, Carlos Augusto Grabois; MACHADO, Cristiani Vieira; LIMA, Luciana Dias de and BAPTISTA, Tatiana Wargas de Faria. Saúde e territorialização na perspectiva do desenvolvimento. Ciênc. saúde coletiva. 2011, vol.16, n.6, pp. 3003-3016.

GALVÃO, Antonio CF, BRANDÃO, Carlos A. Fundamentos, motivações e limitações da proposta governamental dos "Eixos Nacionais de Integração e Desenvolvimento". In: GONÇALVES MF, BRANDÃO CA, GALVÃO ACF (orgs.). Regiões e cidades, cidades nas regiões: o desafio urbano-regional. São Paulo: Editora Unesp: Anpur, 2003. P.187-206.

GIOVANELLA, Lígia. As Origens e as Correntes Atuais do Enfoque Estratégico em Planejamento de Saúde na América Latina. Cadernos de Saúde Pública, RJ, 7(1): 2644, jan/mar, 1991. 
GIOVANELLA, Lígia. As origens e as correntes atuais do enfoque estratégico em planejamento de saúde na América Latina. Cad. Saúde Pública [online]. 1991, vol.7, n.1

GIOVANELLA, Lígia. As Origens e as Correntes Atuais do Enfoque Estratégico em Planejamento de Saúde na América Latina. Cadernos de Saúde Pública, RJ, 7(1): 2644, jan/mar, 1991.

GOTTMANN, J. Acerca do método de análise na Geografia Humana. Boletim de Geografia, ano VII, maio de $1949, \mathrm{n}^{\circ} 74$.

GRÖNE O, GARCIA-BARBERO M; WHO EUROPEAN OFFICE FOR INTEGRATED HEALTH CARE SERVICES. Integrated care: a position papel of the WHO European Office for Integrated Health Care Services. Int J Integr Care. 2001;1:e21.

GUIMARÃES, Fábio de Macedo Soares. Divisão regional do Brasil. Rio de Janeiro: Instituto Brasileiro de Geografia e Estatística (IBGE), 1942. (48p.).

GUIMARÃES, Luisa e FREIRE, José-Manuel. Los temas de salud en la Unión Europea: su impacto en la sanidad española. Cad. Saúde Pública 2007, vol.23, suppl.2, pp. S143S154.

GUIMARÃES, Raul B. Regiões de saúde e escalas geográficas. Cad. Saúde Pública. 21(4):1017-1025, jul-ago, 2005.

GUIMARÃES, Reinaldo. Ciência, Tecnologia e Inovação: um paradoxo na Reforma Sanitária. In: LIMA, Nísia T. et. al. (orgs.). Saúde e Democracia: história e perspectivas do SUS. Rio de Janeiro: Editora Fiocruz, 2005 (p.235-256).

HAESBAERT, Rogério. Desterritorialização, multiterritorialidade e regionalização. MINISTÉRIO DA INTEGRAÇÃO NACIONAL. Secretaria de Políticas de Desenvolvimento Regional. Para pensar uma política nacional de ordenamento territorial: anais da Oficina sobre a Política Nacional de Ordenamento Territorial, Brasília, 13-14 de novembro de 2003. Brasília: MIN, 2005, p.15-29.

HALL P E TAYLOR RCR. As três versões do neo-institucionalismo. Lua Nova 2003; 58: 193-223.

HAM C, HILL M. The Policy Process in the Modern Capitalist State. Hertfordshire: Haverster Wheatsheaf; 1993.

HAMILTON, Wanda e FONSECA, Cristina. "Política, atores e interesses no processo de mudança institucional: a criação do Ministério da Saúde em 1953". Hist. cienc. saudeManguinhos, Dez 2003, vol.10, no.3, p.791-825.

HARTZ, Zulmira M. de Araújo e CONTANDRIOPOULOS, André-Pierre. Integralidade da atenção e integração de serviços de saúde: desafios para avaliar a implantação de um "sistema sem muros". Cad. Saúde Pública. 2004, vol.20, suppl.2, pp. S331-S336 .

HEIMANN, L.S. (et.al.). Gestão Regional do SUS - São Paulo: rumo ao Pacto de Gestão. São Paulo: Instituto da Saúde, 2007. (Temas em Saúde Coletiva 5).

HOBSBAWN, Eric. O Novo Século: entrevista a Antonio Polito. São Paulo: Cia das Letras, 2000.

HOCHMAN, Gilberto. A era do saneamento: as bases da política de saúde pública no Brasil. São Paulo: Hucitec, 2006.

I CONFERÊNCIA INTERNACIONAL SOBRE PROMOÇÃO DA SAÚDE. Carta de Otawa. Canadá, 1986.

IANNI, Octavio. Estado e Planejamento Econômico no Brasil. Rio de Janeiro: Civilização Brasileira, 1971.

IBAÑEZ, Nelso et al. O Pacto pela Saúde e a gestão regional em São Paulo: estudos de caso do mix público privado. In: Viana, A. L. D.; ELIAS, P. E. M. \& Ibañez, N. (orgs.). Saúde, desenvolvimento e território. São Paulo: Hucitec, 2009. (p.268-304).

IBAÑEZ, Nelson; ALBUQUERQUE, Mariana V. de. O SUS: estrutura e organização. In: ROCHA, Juan S. Y. (editor). Manual de saúde pública \& saúde coletiva no Brasil. São Paulo: Editora Atheneu, 2012, p.113-128.

IBAÑEZ, Nelson; VIANA, Ana L.d'A.; ELIAS, Paulo EM. O Pacto pela Saúde e a gestão regional em São Paulo: estudos de caso do mix público privado. In: VIANA, Ana 
L.d'A.; IBAÑEZ, Nelson; ELIAS, Paulo EM (orgs). Saúde, desenvolvimento e território. São Paulo: Hucitec, 2009, p.268-303.

INFORME Dawson sobre el Futuro de los Servicios Medicos y Afines. Traducción al castellano del Dawson Report on the Future Provision of Medical and Allied Services, 1920. Organización Panamericana de la Salud. Publicación Científica n.93, febrero de 1964.

INSTITUTO DE PESQUISA ECONÔMICA APLICADA. Diretoria de Estudos e Políticas Sociais. Políticas sociais: acompanhamento e análise. Brasília-DF: IPEA, 2012.

ISARD, Walter. Location and space-economy. MIT Press, Cambridge MA, 1956.

JORDANA, J. As comunidades autônomas e a política de descentralização na Espanha democrática. In: FLEURY, S (Org). Democracia, descentralização e desenvolvimento: Brasil e Espanha. Rio de Janeiro: Editora FGV, 2006.

JUILLARD, Étienne. A Região: tentativa de definição. Boletim Geográfico. IBGE, nº 185 , p.224-236, 1965.

KAYSER, Bernard. A Região como objeto de estudo da geografia. In George, P.; Kaiser, B. (Orgs.) A Geografia Ativa. São Paulo: Difel, 1975 (1967) (4ªd.).

KEINERT, Tania MM. Gestão Estratégica de Políticas Públicas pelos Governos Subnacionais: Análise da Experiência: Sistemas Microrregionais de Serviços de Saúde no Estado do Ceará . São Paulo: NPP/FGVSP, 2001 (Relatório de Pesquisa).

KUSCHNIR, R. \& CHORNY, A.H.. Redes de atenção à saúde: contextualizando o debate. Ciência e Saúde Coletiva, 15 (5):2307-2316, 2010.

LA BLACHE, P. Vidal de. Princípios de Geografia Humana. Lisboa: Cosmos, 1956.

LA BLACHE, Paul Vidal de. A Geografia na Escola Primária. Boletim Geográfico, ano 1, $\mathrm{n}^{\circ} 1$, abril de 1943. (Originalmente publicado em 1928)

LA FORGIA GM, COUTTOLENC BF. Desempenho hospitalar no Brasil: em busca da excelência. São Paulo: Singular, 2008.

LABASSE, Jean. À procura de um quadro regional. Boletim Geográfico, Rio de Janeiro, no 199, ano 126, jul./ago., p.19-23, 1960.

LABRA, Maria Eliana. 1955-1964: o sanitarismo desenvolvimentista. In: Teixeira, Sonia Fleury (Ed.). Antecedentes da reforma sanitária. Rio de Janeiro: Escola Nacional de Saúde Pública. p.9-36. (Textos de Apoio - Saúde). 1988

LACOSTE, Y. Geografia: isso serve, em primeiro lugar, para fazer a guerra. Papirus, 2003 $\left(1^{\mathrm{a}}\right.$ Ed. 1985).

LAVRAS, Carmen. Atenção primária à saúde e a organização de redes regionais de atenção à saúde no Brasil. Saude soc. 2011, vol.20, n.4, pp. 867-874.

LEITE, Ubajara B. Política Nacional de Desenvolvimento Regional: experiência recente da política regional no Brasil. Comissão Econômica para a América Latina e Caribe (Cepal): Reunión de expertos sobre: "población, território y desarrollo sostenible", Santiago - Chile, 16-17 de agosto de 2011.

LEVCOVITZ, Eduardo; LIMA, Luciana Dias de; MACHADO, Cristiani Vieira. Política de saúde nos anos 90: relações intergovernamentais e o papel das Normas Operacionais Básicas. Ciênc. saúde coletiva. 2001, vol.6, n.2, pp. 269-291.

LEVI, Maria Luiza; SCATENA, João Henrique G. Evolução recente do financiamento do SUS e considerações sobre o processo de regionalização. In: VIANA, Ana Luiza d'Ávila; LIMA, Luciana Dias de. Regionalização e relações federativas na política de saúde do Brasil. Rio de Janeiro: Contra Capa, (p.81-115), 2011.

LIMA, Ana Paula Gil de. Os Consórcios Intermunicipais de Saúde e o Sistema Único de Saúde. Cad. Saúde Pública. 2000, vol.16, n.4, pp. 985-996.

LIMA, Carlos A. S. de. Implementação das Normas Operacionais da Assistência à Saúde (NOAS): transferências de recursos federais para a média e alta complexidade - 2001 2006. In: MELAMED, Clarice \& PIOLA, Sérgio Francisco (orgs.). Políticas públicas e financiamento federal do Sistema Único de Saúde. Brasília: Ipea, 2011. pp.211-238. 
LIMA, L.D. Federalismo, relações fiscais e financiamento do Sistema Único de Saúde: a distribuição de receitas vinculadas à saúde nos orçamentos municipais e estaduais. Rio de Janeiro: Museu da República, 2007.

LIMA, Luciana D. de; QUEIROZ, Lucia de F. N.O Processo de Descentralização e regionalização do SUS no Contexto do Pacto pela Saúde. In: MACHADO, Cristiani V.; BAPTISTA, Tatiana W. de F.; LIMA, Luciana D. de (orgs.). Políticas de Saúde no Brasil: continuidades e mudanças. Rio de Janeiro: Editora Fiocruz, 2012 (pp.229-252).

LIMA, Luciana Dias de et al. Regionalização e acesso à saúde nos estados brasileiros: condicionantes históricos e político-institucionais. Ciênc. saúde coletiva. 2012b, vol.17, n.11 pp. 2881-2892.

LIMA, Luciana Dias de. A Comissão Intergestores Bipartite a CIB do Rio de Janeiro. Physis. 2001, vol.11, n.1, pp. 199-252.

LIMA, Luciana Dias de. Federalismo fiscal e financiamento descentralizado do SUS: balanço de uma década expandida. Trab. Educ. Saúde, v. 6 n. 3, p. 573-597, nov.2008.

LIMA, Luciana Dias de; MACHADO, Cristiani Vieira; ALBUQUERQUE, Mariana Vercesi de; IOZZI, Fabíola Lana. A regionalização da saúde no Brasil. In: GIOVANELLA, L; SCOREL, S. (orgs.). Política e Sistemas de Saúde no Brasil. Rio de Janeiro: Fiocruz, Cebes, 2012a.

LIMA, Luciana Dias de; VIANA, Ana Luiza d'Ávila. Descentralização, regionalização e instâncias intergovernamentais no Sistema Único de Saúde. In: VIANA, Ana Luiza d'Ávila; LIMA, Luciana Dias de (orgs). Regionalização e relações federativas na política de saúde do Brasil. Rio de Janeiro: Contra Capa, 2011. Pp.39-66.

LIMA, Nísia T.; FONSECA, Cristina M. O, HOCHMAN, Gilberto. "A Saúde na Construção do Estado Nacional no Brasil: Reforma Sanitária em Perspectiva Histórica". In: LIMA, Nísia T. et al. (orgs.) Saúde e Democracia: História e perspectivas do SUS. Rio de Janeiro: Editora Fiocruz, 2005. p. 27-58.

LIMA, Nísia Trindade . "O Brasil e a Organização Pan-Americana de Saúde: uma história em três dimensões". In: Jacobo Finkelman. (Org.). Caminhos da Saúde Pública no Brasil. Rio de Janeiro: Editora Fiocruz/OPAS, 2002, v. , p. 23-116.

LIMA, Nísia Trindade. Informe sobre as pestes. Inteligência, ano II, 9:10-20, nov.1999/abr.2000.

LIMA, Nísia Trindade. Um sertão chamando Brasil: intelectuais e representações geográficas da identidade nacional. Rio de Janeiro: Instituto Universitário de Pesquisas do Rio de Janeiro/Ed. Revan, 1999.

LOPES, Clélia MN. Sistemas Microrregionais de Serviços de Saúde no Ceará (1998 - 2006): implantação e resultados na utilização de internações hospitalares. (Dissertação). Universidade Estadual do Ceará, Fortaleza-CE, 2007.

MACHADO CV, BAPTISTA TWF, LIMA LD. O planejamento nacional da política de saúde no Brasil: estratégias e instrumentos nos anos 2000. Ciência e Saúde Coletiva, 2010, (15):2367-2382.

MACHADO, Cristiani V.; OLIVEIRA, Roberta G.; PEREIRA Adelyne M. M.; COELHO, Ana Paula S. O papel das Comissões Intergestores Bipartites na regionalização em saúde. In: VIANA, Ana Luiza d'Ávila; LIMA, Luciana Dias de (orgs). Regionalização e relações federativas na política de saúde do Brasil. Rio de Janeiro: Contra Capa, 2011b, p.173-195.

MACHADO, Cristiani Vieira. Direito universal, política nacional: o papel do Ministério da Saúde na política de saúde brasileira de 1990 a 2002. Rio de Janeiro: Editora Museu da República, 2007.

MACHADO, Cristiani Vieira. O modelo de intervenção do Estado na saúde: notas sobre a atuação federal. In: MACHADO, Cristiani V., BAPTISTA, Tatiana Wargas de Faria, LIMA, Luciana Dias de (orgs.). Políticas de saúde no Brasil: continuidades e mudanças. Rio de Janeiro: Editora Fiocruz, 2012, p.117-148. 
MACHADO, Cristiani Vieira. O modelo de intervenção do Ministério da Saúde brasileiro nos anos 90. Cad. Saúde Pública. 2007, vol.23, n.9, pp. 2113-2126.

MACHADO, Cristiani Vieira. Prioridades de saúde no Brasil nos anos 1990: três políticas, muitas lições. Rev Panam Salud Publica. 2006, vol.20, n.1, pp. 44-49.

MACHADO, Cristiani Vieira. Sobre os rumos das políticas sociais e de saúde no Brasil pós 1988. Cad. Saúde Pública. 2013, vol.29, n.10.

MACHADO, Cristiani Vieira; BAPTISTA, Tatiana Wargas de Faria and NOGUEIRA, Carolina de Oliveira. Políticas de saúde no Brasil nos anos 2000: a agenda federal de prioridades. Cad. Saúde Pública. 2011, vol.27, n.3, pp. 521-532.

MACHADO, Cristiani Vieira; SALVADOR, Fernanda Gonçalves Ferreira and O'DWYER, Gisele. Serviço de Atendimento Móvel de Urgência: análise da política brasileira. Rev. Saúde Pública. 2011c, vol.45, n.3, pp. 519-528.

MAGNAGO, Angélica Alves. A divisão regional brasileira - uma revisão bibliográfica. $R$ Bras Geografia, Rio de Janeiro, v.57, no4, p.64-92, out/dez 1995.

MANZONI NETO, Alcides \& SILVA BERNARDES, Adriana. O planejamento territorial no Brasil nos anos 1990: as ações das empresas globais de consultoria (o caso da BoozAllen \& Hamilton). GEOgraphia, Vol. 10, No 20 (2008).

MARTINELLI NL, VIANA ALD’Á, SCATENA JHG. A relação público-privada na saúde: o caso da região de saúde Médio Norte Mato-grossense. In: Scatena JHG, Kehrig RT, Spinelli MAS (org.). Regiões de Saúde: diversidade e processo de regionalização em Mato Grosso. São Paulo: Hucitec Editora, 2014, p. 426-450 (prelo)

MELGAÇO, Lucas de Melo; ALBUQUERQUE, Mariana Vercesi de. Território Recortado. In: VI Congresso Brasileiro de Geógrafos, 2004, Goiânia - GO. CD do VI Congresso Brasileiro de Geógrafos. Goiânia - GO, 2004.

Mello, Guilherme Arantes and Viana, Ana Luiza d'Ávila. Uma história de conceitos na saúde pública: integralidade, coordenação, descentralização, regionalização e universalidade. Hist. cienc. saude-Manguinhos, Dez 2012, vol.19, no.4, p.1219-1239.

MELLO, Guilherme Arantes. Revisão do pensamento sanitário com foco no Centro de Saúde. Tese (Doutorado) - Faculdade de Medicina, Universidade de São Paulo, São Paulo. 2010.

MELLO, Guilherme Arantes; IBANEZ, Nelson and VIANA, Ana Luiza d'Ávila. Um olhar histórico sobre a questão regional e os serviços básicos de saúde no Estado de São Paulo. Saude soc. 2011, vol.20, n.4, pp. 853-866.

MELLO, Guilherme Arantes; VIANA, Ana Luiza d'Ávila. Centros de Saúde: ciência e ideologia na reordenação da saúde pública no século XX. História, Ciências, Saúde Manguinhos, Rio de Janeiro, v.18, n.4, out.-dez. 2011b, p.1131-1149.

Mendes EV. Reflexão sobre a NOAS SUS 01/02. In: Relatório final do $1^{\circ}$ Seminário do CONASS para a construção de Consensos: preocupações e prioridades dos Secretários Estaduais de Saúde quanto à organização, gestão e financiamento do SUS/Conselho Nacional de Secretários de Saúde. Brasília: CONASS; 2003. p. 65-100.

MENDES, E.V. As redes de atenção à saúde. Ciência e Saúde Coletiva,15(5): 2297-2305, 2010.

MENDES, Eugênio V. A modelagem das redes de atenção à saúde. Belo Horizonte: Secretaria de Estado de Saúde de Minas Gerais, 2007b.

MENDES, Eugênio V. Revisão bibliográfica sobre as Redes de Atenção à Saúde. Belo Horizonte: Secretaria de Estado de Saúde de Minas Gerais, 2007.

MENDES, Eugenio Vilaça . A vigiliância a saúde no distrito sanitário. Brasilia: OPAS, 1993. $104 p$

MENICUCCI, Telma Maria Gonçalves. A política de saúde no governo Lula. Saude soc. 2011, vol.20, n.2, pp. 522-532.

MORAES, Antonio Carlos R. Geografia: pequena histórica crítica. São Paulo: Hucitec, 1999. 
MORAES, Antonio CR. Ordenamento territorial: uma conceituação para o planejamento estratégico. In: MINISTÉRIO DA INTEGRAÇÃO NACIONAL. Secretaria de Políticas de Desenvolvimento Regional. Para pensar uma política nacional de ordenamento territorial: anais da Oficina sobre a Política Nacional de Ordenamento Territorial, Brasília, 13-14 de novembro de 2003. Brasília: MIN, 2005.

MOURÃO, Julio OF. A integração competitiva e o planejamento estratégico no sistema BNDES. Revista do BNDES, Rio de Janeiro, v. 1, n. 2, p. 3-26, dez. 1994.

MUNIZ, Érico S. A. Basta aplicar uma injeção? Saúde, doença e desenvolvimento: o programa de erradicação da bouba no Brasil (1956-1961). [Mestrado] Fiocruz, Rio de Janeiro, 2009.

NASCIMENTO, Vânia B. Interdependência e autonomia na gestão pública da saúde. Lua Nova, nº52. São Paulo: CEDEC, 2001. pp. 29-69.

NASCIMENTO, Vânia B. SUS: federativo e gestão pública. São Paulo: Aderaldo \& Rotschild Ed.; Santo André, SP: Cesco, 2007.

NERI, Marcelo. A nova classe média: o lado brilhante da base da pirâmide. São Paulo: Saraiva, 2011.

NORONHA, J.C. \& SOARES, L.T. A política de saúde no Brasil nos anos 90. Ciência e Saúde Coletiva, 6(2):445-450, 2001.

OLIVEIRA Paulo de Tarso R. O Sistema Único de Saúde, descentralização e a desigualdade regional: um enfoque sobre a região da Amazônia Legal. [Tese de Doutorado] Rio de Janeiro: Escola Nacional de Saúde Pública, Fundação Oswaldo Cruz; 2005.

OLIVEIRA, Evangelina X. G., CARVALHO, Marília Sá e TRAVASSOS, Cláudia. Territórios do Sistema Único de Saúde - mapeamento das redes de atenção hospitalar. Cadernos de Saúde Pública, Rio de Janeiro, 20(2):386-402, mar./abr., 2004.

OLIVEIRA, Francisco de. Elegia para uma re(li)gião: Sudene, Nordeste, Planejamento e conflito de classes. Rio de Janeiro, Paz e Terra, 1977.

ORGANIZAÇÃO DOS ESTADOS AMERICANOS. Ata de Bogotá: Medidas de melhoramento social e desenvolvimento econômico dentro do quadro da "Operação Pan-Americana". Firmada em 12 de setembro de 1960, sessão do Comitê dos 21 (Comissão Especial do Conselho da OEA para Estudar a Formulação de Novas Medidas de Cooperação Econômica). Revista Brasileira de Política Internacional, Ano III, $\mathrm{n}^{\circ}$.12, 1960. pp.188-194.

ORGANIZAÇÃO DOS ESTADOS AMERICANOS. Carta de Punta del Leste: Estabelecimento da Aliança para o Progresso dentro da estrutura da Operação PanAmericana. Firmada em 1961, no Uruguai, em reunião especial do Conselho Interamericano Econômico e Social. Revista Brasileira de Política Internacional, Ano IV, n'.16, 1961. pp.157-169.

ORGANIZACÃO PAN-AMERICANA DE SAÚDE. A atenção à saúde coordenada pela Atenção Primária de Saúde (APS): construindo as redes de atenção no SUS. Contribuições para o debate. Brasília-SF: Organização Pan-Americana de Saúde, $2010 b$.

ORGANIZACION PANAMERICANA DE LA SALUD. Redes Integradas de Servicios de Salud: Conceptos, Opciones de Política y Hoja de Ruta para su Implementación en las Américas. Washington DC: Organizacion Panamericana de La Salud, 2010a.

PENA, Maria Valéria Junho. Saúde nos Planos Nacionais de Desenvolvimento. Dados Revista de Ciências Sociais. Rio de Janeiro. n.16, p.69-96, 1977.

PEREIRA, Adelyne Maria Mendes. Dilemas Federativos e Regionalização na Saúde: o papel do gestor estadual do SUS em Minas Gerais. [Dissertação]. Escola Nacional de Saúde Pública/Fundação Oswaldo Cruz. Rio de Janeiro-RJ, 2009.

PERES, RB e CHIQUITO, EA. Ordenamento territorial, meio ambiente e desenvolvimento regional: novas questões, possíveis articulações. R. B. Estudos Urbanos e Regionais, v.14, n.2, novembro de 2012. 
PERROUX, F. Pour une philosophie du nouveau development. Paris: Aubier, Presses de UNESCO, 1981.

PESSOA, Samuel. Ensaios médico-sociais. São Paulo: Cebes; Hucitec, 1978 (2a edição).

Pierson P. Politics in time. Princeton: Princeton University Press; 2004.

PINTO, Marco A C. O BNDES e o sonho do desenvolvimento: 30 anos de publicação do II PND. Revista do BNDES, Rio de Janeiro, v. 11, n. 22, P. 51-79, dez. 2004

PIQUET, R.P.S. \& RIBEIRO, A.C.T. Tempos, ideias e lugares: o ensino do planejamento urbano e regional no Brasil. Revista Brasileira de Estudos Urbanos e Regionais, 10 (1): 49-59, 2008.

POCHMANN, Marcio. Nova classe média? : o trabalho na base da pirâmide social brasileira. São Paulo: Boitempo, 2012.

QUEIROZ, Lúcia F. N. A regionalização da assistência à Saúde no Brasil: avanços e dificuldades na implantação da NOAS-SUS. Res Pvblica, Brasilia, v. III, n. 04, p. 9-36, 2004.

RAFFESTIN, Claude. Por uma geografia do poder. São Paulo: ed. Ática, 1993.

RIBEIRO J.M.; COSTA N.R. da. Regionalização da assistência à saúde no Brasil: os consórcios municipais no Sistema Único de Saúde (SUS). Planejamento e Políticas Públicas, n. 22, p.173-220, dez. 2000.

RIBEIRO, Ana Clara T. Regionalização: fato e ferramenta. In: LIMONAD, E.; HAESBAERT, R.; MOREIRA, R. (Org.). Brasil, século XXI - por uma nova regionalização?: Agentes, processos e escalas. São Paulo: Max Limonad, 2004b. p. 194-212.

RIBEIRO, Paulo de Assis; FERREIRA, Manoel José; BRAGA, Ernani. Economic value of health. Rev. Bras. Epidemiol. Vol. 1, No 3, 1998, pp.303-344.

RIVERA, Francisco Javier Uribe. Aspectos históricos do planejamento de saúde na América Latina. Revista Saúde em Debate, (14): 45-9, 1982.

RIVERA, Francisco Javier Uribe. Por um modelo de Formulação de políticas de saúde baseado no enfoque estratégico da planificação. Cadernos de Saúde Pública, RJ, 4(3): 444-462, out/dez, 1987.

ROCHA NETO JM, BORGES DF. As assimetrias entre as políticas setoriais e a política de planejamento regional no Brasil. Rev. Adm. Pública 2011, 45(6):1639-1654.

ROCHA NETO, João Mendes da. Cooperação e Competição entre políticas públicas no Brasil: os custos da governabilidade no presidencialismo de coalizão. Tese. Depto de Ciências Administrativas, da Universidade Federal do Rio Grande do Norte, Natal RN, 2012.

ROCHEFORT, Michel. Como a presença de uma grande cidade diversifica as aglomerações de uma região. Revista Brasileira dos Municipios, n 53/54, ano XIV, 1961.

ROCHEFORT, Michel. Entrevista. Revista Experimental, nº4/5, p.115-138, setembro, 1998.

ROCHEFORT, Michel. Regionalização e Rede Urbana. Caderno Prudentino de Geografia. Edição Especial Michel Rochefort. Presidente Prudente: AGB, n. 4, 1982, p. 7-27.

ROJAS, Luisa Iñiguez. Geografía y salud: temas y perspectivas em América Latina. Cadernos de Saúde Pública, Rio de Janeiro, 14(4):701-711, out/dez., 1998.

ROSEN, George. Uma história da saúde pública. São Paulo: Hucitec: Editora da Universidade Estadual Paulista, $3^{a}$ edição, 2006. (1 ${ }^{\text {a }}$ Ed. brasileira 1994) (1 ${ }^{\text {a }} \mathrm{Ed}$. americana 1985).

RÜCKERT, Aldomar A. O processo de reforma do Estado e a Política Nacional de Ordenamento Territorial. MINISTÉRIO DA INTEGRAÇÃO NACIONAL. Secretaria de Políticas de Desenvolvimento Regional. Para pensar uma política nacional de ordenamento territorial: anais da Oficina sobre a Política Nacional de Ordenamento Territorial, Brasília, 13-14 de novembro de 2003. Brasília: MIN, 2005, p.31-39.

SABROZA, Paulo. Conferência realizada no II Simpósio de Geografia da Saúde. Rio de Janeiro, novembro de 2005. 
SACARDO, D.P.; FORTES, P.A.C. \& TANAKA, O.Y. Novas perspectivas na gestão do sistema de saúde da Espanha. Saúde Soc. São Paulo, 2011; 19(1), p. 170-179.

SANO, Hironobu and ABRUCIO, Fernando Luiz. Promessas e resultados da Nova Gestão Pública no Brasil: o caso das organizações sociais de saúde em São Paulo. Rev. adm. empres. 2008, vol.48, n.3, pp. 64-80.

SANTOS, Lenir e ANDRADE, Luiz Odorico Monteiro de. Redes interfederativas de saúde: um desafio para o SUS nos seus vinte anos. Ciênc. saúde coletiva. 2011, vol.16, n.3, pp. 1671-1680.

SANTOS, Lenir e ANDRADE, Luiz O. M. de. SUS: o espaço da gestão inovada e dos consensos interfederativos: aspectos jurídicos, administrativos e financeiros. Campinas, SP: Instituto de Direito Sanitário Aplicado, 2007.

SANTOS, Lenir. "O que são redes?". In: SILVA, Silvio Fernandes da (org.). Redes de Atenção à Saúde no SUS: o pacto pela saúde e redes regionalizadas de ações e serviços de saúde. Campinas, SP: IDISA: CONASEMS, 2008. (p.29-34).

SANTOS, Lenir. SUS: desafios político-administrativos da gestão interfederativa da saúde, regionalizando a descentralização. [Tese]. Faculdade de Ciências Médicas da Universidade Estadual de Campinas - FCM/Unicamp. Campinas-SP, 2012.

SANTOS, Luiz A. de Castro. As Origens da Reforma Sanitária e da Modernização Conservadora na Bahia durante a Primeira República. Dados. 1998, vol.41, n.3.

SANTOS, Luiz Antonio de Castro. O pensamento sanitarista na Primeira República: Uma ideologia de construção da nacionalidade. Dados. Revista de Ciências Sociais, Rio de Janeiro, v.28, n.2, p.193-210, 1985.

SANTOS, M. A natureza do espaço: técnica e tempo, razão e emoção. São Paulo: Hucitec, 1996.

SANTOS, M. Por uma outra globalização, do pensamento único à consciência universal. 3. ed. Rio de Janeiro e São Paulo: Record, 2000.

SANTOS, M.; SILVEIRA, M.L. O Brasil: território e sociedade no início do século XXI. Rio de Janeiro e São Paulo: Record, 2001.

SANTOS, Milton. "Sociedade e Espaço: A Formação Social como Teoria e como Método". Boletim Paulista de Geografia. São Paulo, no. 54, p.81-100, jun. de 1977.

SANTOS, Milton. A Urbanização Brasileira. São Paulo: Hucitec, 1993. (5ª ed.:Edusp: 2005).

SANTOS, Milton. Economia Espacial. São Paulo: Hucitec, 1979. (2 $2^{\mathrm{a}}$ ed. Edusp: 2003).

SANTOS, Milton. Espaço e Método. São Paulo: Hucitec, 1985. (3 $3^{\text {a }}$ ed.: 1992).

SANTOS, Milton. Metrópole corporativa e fragmentada: o caso de São Paulo. São Paulo: Nobel, 1990.

SANTOS, Milton. O Território e o Saber Local: algumas categorias de análise. Cadernos IPPUR. Ano XII, n², 1999. Rio de Janeiro: UFRJ. p.15-25.

SANTOS, Milton. Por um novo planejamento urbano e regional. Anais do IV Encontro Nacional da ANPUR. Salvador, maio de 1991.

SANTOS, Milton. Por uma Geografia Nova. São Paulo: Hucitec, 1978 (EDUSP, 2002).

SANTOS, Milton. Técnica, Espaço, Tempo: Globalização e meio técnico-científico informacional, Hucitec, São Paulo, 1994b.

SANTOS, Thereza C. Algumas considerações preliminares sobre Ordenamento Territorial. In: Ministério da Integração Nacional. Secretaria de Políticas de Desenvolvimento Regional. Para pensar uma política nacional de ordenamento territorial: anais da Oficina sobre a Política Nacional de Ordenamento Territorial, Brasília, 13-14 de novembro de 2003. Brasília: MI, 2005, p.49-54.

SANTOS, W. G. Cidadania e justiça. Rio de Janeiro: IUPERJ/Vértice, 1979.

SCLIAR, Moacyr. História do conceito de saúde. Physis. 2007, vol.17, n.1, pp. 29-41

SCOTT RW. Institutions and Organizations. Sage Publ Series. Thousand Oaks; 1995: 178 pp. Passim. 
SHORTELL SM, GILLIES RR and ANDERSON DA. The new world of managed care: creating organized delivery systems. Health Affairs, 13, n5 (1994): 46-64.

SILVA HP, VIANA ALd'Á. Health technology diffusion in developing countries: a case study of CT scanners in Brazil. Health Policy and Planning 2011; 26:385-394.

SILVA NETO, Manoel Lemes da. "A questão regional hoje: reflexões a partir do caso paulista". In: SOUZA, Maria Adélia A. de. Território Brasileiro: usos e abusos. Campinas, Edições Territorial, 2003, p.355-379.

SILVA, Hudson Pacífico da. Dimensões da Saúde no Brasil: proteção social, inovação tecnológica e acumulação de capital [Tese]. Faculdade de Medicina da Universidade de São Paulo, São Paulo, 2007.

SILVA, Silvio Fernandes. "Implantando o Pacto pela Saúde e aperfeiçoando as redes de atenção do SUS". In: SILVA, Silvio Fernandes da (org.). Redes de Atenção à Saúde no SUS: o pacto pela saúde e redes regionalizadas de ações e serviços de saúde. Campinas, SP: IDISA: CONASEMS, 2008. (p.15-20).

SILVA, Silvio Fernandes. A saúde na Espanha e comparação com o Brasil. Texto preparado pelo Núcleo de Relações Internacionais do CONASEMS. 2007.

SILVA, Vanessa CS. O processo de implantação do Sistema Integrado de Serviços de Saúde em Vitória - ES: contribuição à discussão da integralidade na atenção à saúde. (Dissertação) ENSP/Fiocruz, Rio de Janeiro, 2004.

SILVEIRA, M. L. Diferencias regionales en el territorio brasileño: perspectiva diacrónica y sincrónica. Scripta Nova. Revista Electrónica de Geografía y Ciencias sociales. Barcelona: Universidad de Barcelona, 15 de julio de 2007, vol. XI, núm. 244.

SILVEIRA, M.L. A região e a invenção da viabilidade do território. In: SOUZA, M.A.A. de (Org.). Território Brasileiro: usos e abusos. Campinas: Territorial, 2003. p. 408-416.

SILVEIRA, M.L. Região e Globalização: pensando um esquema de análise. REDES, Santa Cruz do Sul, 15(1): 74-88, 2010.

SILVEIRA, M.L. Uma situação geográfica: do método à metodologia. Revista Território, Revista do Laboratório de Gestão do Território - UFRJ, IV(6). Rio de Janeiro, jan./jun., 1999.

SILVEIRA, María Laura. Território usado: dinâmicas de especialização, dinâmicas de diversidade. Ciência Geográfica, v. XV, p. 4-12, 2011.

SOLA, Lourdes. Estado, transformação econômica e democratização no Brasil. In: SOLA, L. (org). Estado, mercado e democracia: política e economia comparadas. São Paulo - SP: Editora Paz e Terra, 1993, p.235-279.

SOUZA SANTOS, Boaventura. A crítica da governação neoliberal: o Fórum Social Mundial como política e legalidade cosmopolita subalterna. Revista Crítica de Ciências Sociais, 72, Outubro 2005: 7-44.

SOUZA, Celina. Federalismo e gasto social no Brasil: tensões e tendências. Lua Nova, nº52. São Paulo: CEDEC, 2001. pp. 05-28.

SOUZA, Celina. Regiões metropolitanas: condicionantes do regime político. Lua Nova, 59: 137-159, 2003.

SOUZA, M.A.A. de. A explosão do território: falência da região? Boletim de Geografia Teorética, 22 (43-44): 393-398, 1992.

SOUZA, Maria Adélia A. de. Conexões Geográficas: um ensaio metodológico. Boletim Paulista de Geografia, n.71, 1995.

SOUZA, Maria Adélia A. de. O II PND e a política urbana brasileira: uma contradição evidente. In: DEÁK, CSABA \& SCHIFFER, Sueli R (orgs.). O processo de urbanização no Brasil. São Paulo: Editora da Universidade de São Paulo, 2004. p.111144.

SOUZA, Maria Adélia A. de. Regionalização: o tema geográfico e político - o caso paulista. In: AGB. Boletim Paulista de Geografia. São Paulo, nº50, mar. 1976.

SOUZA, Renilson Rehem de. A regionalização no contexto atual das políticas de saúde. Ciência e Saúde Coletica. 2001, 6(2), p. 451-455. 
STEINBERGER, Marília, (org.). Território, ambiente e políticas públicas espaciais. Brasília: Paralelo 15 e LGE Editora, 2006.

TANAKA, O.Y. et al. Gerenciamento do setor saúde na década de 80, no Estado de São Paulo. Saúde pública, São Paulo, v. 26, n. 3. p. 185-94, 1992.

TAVARES, Francisco A. et al. Novas perspectivas na gestão para resultados na saúde em Minas Gerais: a implantação dos contratos organizativos de ação pública de saúde. VI Congresso Consad de Gestão Pública. Centro de Convenções Ulysses Guimarães, Brasília-DF, 16 a 18 de abril de 2013.

TEIXEIRA, C. F.; PAIM, J. S. A política de saúde no governo Lula e a dialética do menos pior. Saúde em Debate, Rio de Janeiro, v. 29, n. 71, p. 268-283, 2005.

TEIXEIRA, Sônia M. Fleury (coord.). Antecedentes da Reforma Sanitária. Fundação Oswaldo Cruz/Escola Nacional de Saúde Pública - Programa de Educação Continuada: Rio de Janeiro, 1988.

TEIXEIRA, Sonia Maria Fleury (org.). Projeto Montes Claros: a utopia revisitada. Rio de Janeiro: Abrasco, 1995.

TEMPORÃO, J. G. e GADELHA, C. "Saúde em um novo modelo de desenvolvimento". Folha de São Paulo, 27/05/07.

TEMPORÃO, José Gomes. A Propaganda de Medicamentos e o Mito da Saúde. Rio de Janeiro: Graal, 1986.

TENTORI, Fortunato Vargas. Extensión de la cobertura, atención primaria de salud y participación de la comunidad: deficiniones y conceptos operativos. Trabalho apresentado al Grupo de Estudio sobre Extensión de la Cobertura, Atención Primaria de Salud y Participación, Cocoyoc, Morelos, México, 21 de febrero al 4 de marzo de 1977.

THELEN K, STEINMO S, editors. Structuring Politics. Historical Institucionalism in Comparative Analysis. Cambridge: Cambridge University Press; 1992.

TOBAR, Frederico. Nova racionalidade técnica. In: TEIXEIRA, Sonia Maria Fleury (org.). Projeto Montes Claros: a utopia revisitada. Rio de Janeiro: Abrasco, 1995. (p.101-126)

TOUATI, Nassera et al. Governance, health policy implementation and the added value of regionalization. Healthcare Policy, vol.2, n³, 2007, p.97-114.

TOZI, F. O território como recurso: a privatização das telecomunicações no Brasil. Do leilão dos fragmentos à totalidade do território. Geosul (UFSC), v. 24, p. 47-66, 2009.

VAINER, C.B. Interdisciplinaridade e estudos regionais. In: MELO, J.G. Região, cidade e poder. Presidente Prudente: GAsPERR, 1996. p.11-32.

VARGA, István van Deursen. Fronteiras da urbanidade sanitária: sobre o controle da malária. Saude soc. 2007, vol.16, n.1, pp. 28-44.

VELLOSO, João Paulo dos Reis. Entrevista. “O IPEA tem que ser independente”. Revista Isto é Dinheiro num. 0531, 26/11/2007

VIANA AL, LIMA LD, FERREIRA MP. Condicionantes estruturais da regionalização na saúde: tipologia dos Colegiados de Gestão Regional. Ciência e Saúde Coletiva, v.15, n.5, p. 2317-2326, 2010.

VIANA AL, SILVA HP, ELIAS PEM. Economia política da saúde: introduzindo o debate. Divulgação em Saúde para Debate 2007; (37):7-20.

VIANA ALD E BAPTISTA TWF. Análise de Políticas de Saúde. In: Giovanella L et al. (orgs). Políticas e Sistema de Saúde no Brasil. Rio de Janeiro: Fiocruz; 2008. p. 65-105.

VIANA, A.L. d`Á. et al. Sistema de saúde universal e território: desafios de uma política regional para a Amazônia Legal. Cad. Saúde Pública, Rio de Janeiro, v. 23, supl. 2, p. S117- S131, 2007a.

VIANA, A.L. d’Á.; LIMA, L.D.; OLIVEIRA, R.G. Descentralização e federalismo: a política de saúde em novo contexto - lições do caso brasileiro. Ciência e Saúde Coletiva, Rio de Janeiro, v. 7, n. 3, p. 493-507, 2002.

VIANA, A.L.D. et al. Novas perspectivas para a regionalização da saúde. São Paulo em Perspectiva, 22 (1): 92-106, 2008. 
VIANA, ALD; IBAÑEZ, N. Entrevista: Ministro da Saúde José Gomes Temporão. Rev Política, Planejamento e Gestão em Saúde, 2010; 1(1), 157-170.

VIANA, Ana L. D. ; MACHADO, Cristiani V. ; LIMA, Luciana D. de ; HEIMANN, Luiza S. ; IOZZI, Fabíola L. ; ALBUQUERQUE, Mariana. V. de . Protección social en salud y desigualdad territorial: el contexto de la Amazonia Legal brasileña. In: Bello, Amparo Hernández; Sotelo, Carmen Rico de. (Org.). Protección social en salud en América Latina y el Caribe: investigación y políticas. 1ed. Bogotá: Editorial Ponticifia Univerdidad Javeriana, 2011, v.1, p. 187-234.

VIANA, Ana L. D’Á, ELIAS, Paulo e IBAÑEZ, Nelson. Proteção Social: dilemas e desafios. São Paulo: Hucitec, 2005.

VIANA, Ana Luiza d' Ávila; SILVA, Hudson Pacífico. Desenvolvimento e Institucionalidade da Política Social no Brasil. In: MACHADO, Cristiani V.; BAPTISTA, Tatiana W. de F.; LIMA, Luciana D. de (orgs.). Políticas de Saúde no Brasil: continuidades e mudanças. Rio de Janeiro: Editora Fiocruz, 2012 (pp.31-60).

VIANA, Ana Luiza d’Ávila and SILVA, Hudson Pacífico da. Avaliando a difusão de tecnologias médicas no sistema de saúde privado no Brasil: o caso da tomografia por emissão de pósitrons (PET). Rev. Bras. Saude Mater. Infant. 2010, vol.10, suppl.1, pp. s187-s200.

VIANA, Ana Luiza d'Ávila. As diferentes institucionalidades da política social no Brasil no período de 1995 a 2010. VIANA, Ana Luiza d'Ávila; LIMA, Luciana Dias de (orgs). Regionalização e relações federativas na política de saúde do Brasil. Rio de Janeiro: Contra Capa, 2011, p.27-38.

VIANA, Ana Luíza D’Ávila. Novos riscos, a cidade e a intersetorialidade das políticas públicas. Revista de Administração Pública - RAP, Rio de Janeiro, 32(2):23-33, mar/abr., 1998.

VIANA, Ana Luiza d'Ávila. Sistema e descentralização - A política de saúde no estado de São Paulo nos anos 80: formação e tensões. [Tese]. Universidade Estadual de Campinas, UNICAMP. Campinas-SP, 1994.

VIANA, Ana Luiza d'Ávila; LIMA, Luciana Dias de (orgs). Regionalização e relações federativas na política de saúde do Brasil. Rio de Janeiro: Contra Capa, 2011.

VIANA, Ana Luiza d'Ávila; LIMA, Luciana Dias de [coord.]. Relatório Estadual de Sergipe. Avaliação nacional das Comissões Intergestores Bipartites (Cibs): as Cibs e os modelos de indução da regionalização no SUS, maio de 2010.

VIANA, Ana Luiza d'Ávila; ELIAS, Paulo Eduardo M. Saúde e desenvolvimento. Ciênc. saúde coletiva, 2007, vol.12, suppl., pp. 1765-1777.

VIANA, Ana Luiza d'Ávila; LIMA, Luciana Dias de and FERREIRA, Maria Paula. Condicionantes estruturais da regionalização na saúde: tipologia dos Colegiados de Gestão Regional. Ciênc. saúde coletiva. 2010, vol.15, n.5, pp. 2317-2326.

VIANA, Ana Luiza d'Ávila; MACHADO, Cristiani Vieira. Descentralização e coordenação federativa: a experiência brasileira na saúde. Ciênc. saúde coletiva, Rio de Janeiro, v. 14, n. 3, June 2009.

VIANNA, Maria Lucia Teixeira Werneck. Universalismo $x$ Focalização e outras controvérsias: espécies em extinção? In: MELAMED, Clarice \& PIOLA, Sérgio Francisco (orgs.). Políticas públicas e financiamento federal do Sistema Único de Saúde. Brasília: Ipea, 2011. pp.15-34.

VILAÇA, Flávio. Uma contribuição para a história do planejamento urbano no Brasil. In: DÉAK, Csaba \& SCHIFFER, Sueli R. (orgs). O processo de urbanização no Brasil. São Paulo: Editora da Universidade de São Paulo, 2004, p.p.169-244.

VILLALBÍ, Joan R; ANTÓ, Josep M; PANÉ, Olga; PERAY, Jospe L de. Propuestas de reforma de los servicios de salud pública en Cataluña. Rev Esp Salud Pública, 2006, 80, $\mathrm{n}^{\circ} 5, \mathrm{pp} .567-583$. 
WALDMAN, Eliseu A. A transição epidemiológica: tendências e diferenciais dos padrões de morbimortalidade em diferentes regiões do mundo. O Mundo da Saúde - São Paulo, ano 24 v. 24 n 1 , jan./fev. 2000. pp.10-17.

WORLD HEALTH ORGANIZATION REGIONAL OFFICE FOR EUROPE`s HEALTH EVIDENCE NETWORK. Are disease management programmes (DMPs) effective in improving quality of care for people with chronic conditions? Copenhagen, WHO/HEN, 2003.

WORLD HEALTH ORGANIZATION. The World Health Organization: health systems: improving performance. Geneva, Switzerland, 2000b.

WORLD HEALTH ORGANIZATION. Towards Unity for Health - TUFH. Geneva, Switzerland, 2000a.

YUNES, João. O SUS na lógica da descentralização. Estudos Avançados, 13(35), 1999, pp.51-64.

YUNES, João. Os níveis de saúde no município de São Paulo de 1961 a 1967. Revista de Saúde Pública, São Paulo, 3 (1): 41-50, jun., 1969 b.

YUNES, João. Situação dos serviços oficiais de saúde pública na região do grande São Paulo em 1967. Revista de Saúde Pública, São Paulo, 3(1): 51-58, jun., 1969a. 